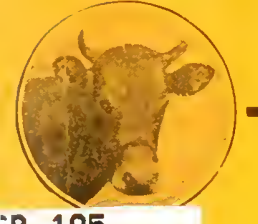

B 195

I4

¿opy 1
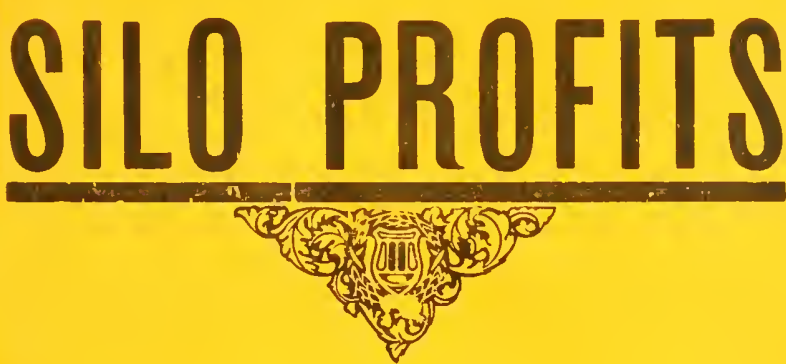

WRITTEN BY 200 OF THE BEST

FARMERS IN AMERICA 



\section{SILO PROFITS}

\section{A COMPILATION OF FACTS AND}

\section{FIGURES}

\section{Copgright $1: 10$}

AlI rights reserved.

PUBLISHED BY

INDIANA SILO CO.

ANDERSON, IND.. U.S. A. 


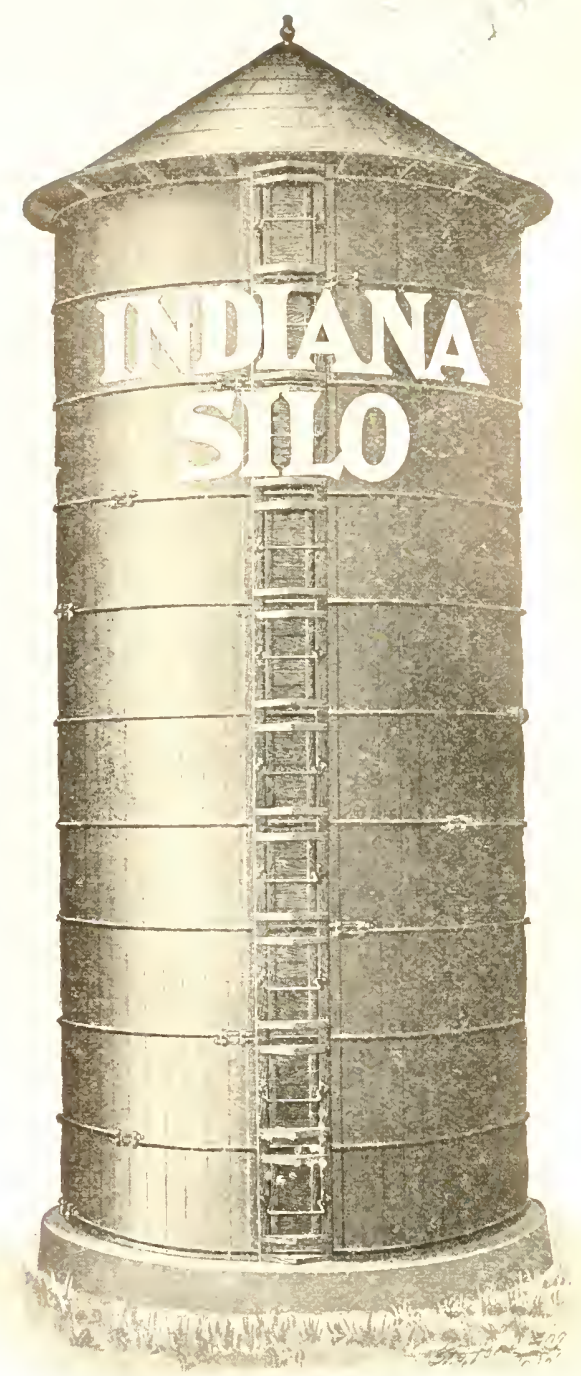




\section{INTRODUCTION}

The idea of this publication is to provide those who are not receiving the benefits of the Silo with such definite and detailed information as will enable them to more intelligently consider the sub ject from their own individual standpoints.

We realize the immense benefits to be derived from the use of this feed and labor saving device. We believe that lack of knowledge of these benefits must be the chief cause why more of them are not in use.

Knowing these things, and believing that those who have had experience are the best qualified to give the desired information, we issued the following letter to a number of our customers:

We have concluded that the best way to find out the actual results, in dollars and cents, of the use of the Indiana Silo, is to ask the men who use them. To make this more interesting we are offering prizes as mentioned below. This letter is being sent to a few of our best customers and you have a good chance to win one of the prizes. Here it is

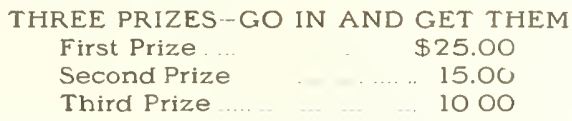

These prizes will be given for three best articles written by users of Indiana Silos as to the profit they have made by their use. Below are given a few pointers as to the features they will be judged upon.

No articles should contain more than five hundred words.

The more specific the article, the better.

Preference will be given to articles that give exact figures as to profits shown by the use of Silos.

No attention whatever will be paid to literary features of articles, so lack of experience in writing need not keep any one out of this contest.

An additional $\$ 5.00$ will be given to the successful contestants if article is accompanied by a photo of self, herd, or barn and Silo, that can be used for a cut to print with the article.

The articles will be published in book form and a copy of same will be sent to each contestant. Help us to help you and we will have a book of helpful information.

Give us the facts as to what your Silo has done for you and you have just as good a chance to win a prize as any one.

Do it now as we will not call your attention to it again.

Yours very truly,

INDIANA SILO COMPANY. 
We have received a great many responses to this letter. These were referred to Mr. DeWitt C. Wing, associate editor of "The Breeders' Gazette," who passed on them and awarded the prizes. The articles winning prizes are the first three reproduced. Mr. Wing came to his decision, so he later said, largely from the fact that the winning articles appeared to him more comprehensive of the many advantages of the Silo.

It was promised that we would reproduce these in book form, and we take an even greater pleasure in doing this than we could have anticipated. We can understand how it was Mr. Wing had so great difficulty in deciding just where to award the prizes. The articles are all excellent. We accompany some of them with photographs and we commend to every farmer, whether he is a user of the Silo or not, the most careful reading of these contributions.

One matter of extraordinary interest to us in regard to these articles is the diversity of their points of view. Each contributor has treated the Silo, its uses and advantages, out of his own experience and to an extent very unusual, we think, each contributor has some fact or some method of treatment that gives a distinct value to his contribution, and makes it so that the reader will not know all that the Silo will do unless he reads all of these articles. In view of this we believe that not one of these articles should be overlooked by any farmer, stockraiser, or dairyman, and we assure our friends that all of them taken together make a book that is most comprehensive in regard to the Silo, a book that will be most profitable, to any farmer whether he have a Silo or not, and withal a book that will be of surpassing interest to all who are in any way connected with the feeding business

This in mind, we take great pleasure in publishing this book. We dedicate it to our thousands of customers jwho are now using Indiana Silos, and we send it to the contributors and others who may desire it as an evangel of the Silo as the modern feeding device, and the promise of more profit and better things for the farmer, stockraiser and dairyman.

THE INDIANA SILO COMPANY, ANDERSON, INDIANA 


\section{FIRST PRIZE ARTICLE}

Indiana Silo Co., Anderson, Ind.

Gentlemen:-Have been feeding silage ten years, but the last bunch of cattle we fed illustrates the value of a silo better than any one experiment we ever made.

Father bought of a speculator, scalper as it were, 17 heifers, culls left over from the Monday's Chicago market on a lump sale, and as usual in such a case, got the cattle too high. When we weighed them they cost us $4 \mathrm{c}$ per pound, when they should have cost from 3 to $31 / 2 \mathrm{c}$ per pound, but to make the best of a bad bargain we put them on a full feed of silage, and fed them 60 days and sold them on the Indianapolis market at $\$ 4.65$ per hundred, which made us a little money. We fed them a little shelled corn along during the time which I charge in the following statement which shows for itself:

Cost of cattle laid down here-17 heifers-9,500 lbs.... .\$380.00

Twelve tons silage fed-30 lbs, per day..............

Sixty-four bushels corn at $60 \mathrm{c}-2 \mathrm{c}$ for hauling.......... 37.12

Total cost without silage which grew on one acre...\$417.12

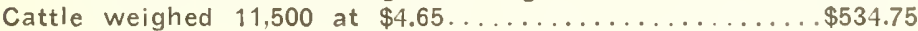

Less commission and proportional freight........... 15.50

$\$ 519.25$

417.12

Less cost of cattle and corn.

Received for 12 tons of silage.............\$102.13

This 12 tons of silage grew on one acre and was put into the silo at

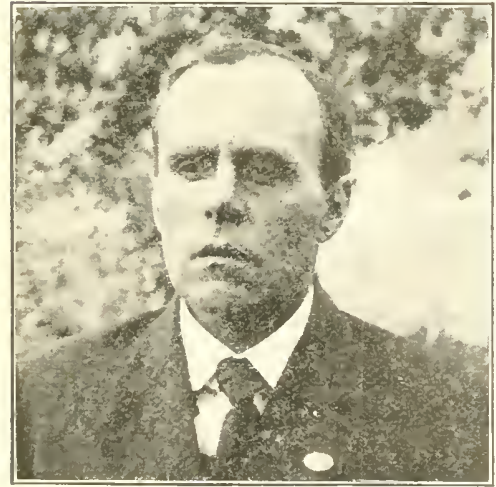

Maurice Douglas.

a cost of $\$ 8.40$, leaving a net value of one acre of corn crop $\$ 93.73$, as compared with the corn that we sold on the market from the strip adjoining as follows: 65 bu. per acre at EOc, $\$ 39.00$, with an expense of $5 c$ per bu, for husking and drawing to market, leaving $\$ 39.00-\$ 3.25-$ $\$ 35.75$ the net value of the acre ad. joining as compared with $\$ 93.73$. I count the trouble of feeding them as balanced by the manure. If these cattle had been bought right at $3 / 2 \mathrm{C}$ per pound, we would have had $\$ 47.50$ more to show for one acre of corn put up as silage, or \$141.23.

With this fact before us we wlll try to get the entire corn crop into silos as soon as possible to arrange for it. We, also, appreciated the silo during the drouth of 1908, which was escecially severe here in this section. We had ensilage to feed our Brood Cows until the 1 st of June and filled the silo the last of September and commenced feeding it immediately as the pastures were burned up, and our cattle went into Winter in good shape.

We feed it to everything, cattle, horses, hogs, sheep and poultry, and have good results. We are feeding a lot of 15 cows, with young calves, silage 40 pounds per day, and what clover and alfalfa hay they will eat, and they are in better shape than when they started in the Winter. It is 
surprising how little hay they eat. I have built three silos of different makes. The last an Indiana, one piece stave silo, which has proven very satisfactory-so much so that every wooden silo in our county is an Indiana with the improvement of continuous doors, etc.

As a conditioner of show cattle we think it has no equal. We opened our silo the 1 st of December, and have fed 40 sheep, 50 head of cattle, 10 head of horses, poultry ever since, and think we have enough on hand to feed until May 1st. I have fed my breeding stallions silage, and they are shedding coats March 1st. In fact, to do without the silo and farm economically on $\$ 125.00$ per acre land, would be feeding at a loss instead.

Since writing the above, have had 18 inches of snow, and others had to ship their cattle as they could not haul their feed to the cattle, while 1 figure we made our greatest gain at that time as our silage was all ready at any time to feed.

Silage is harvested at a time when the weather is good and a maximum amount of labor can be obtained for the regulation price, and we are sure anyone who has the nerve to build a silo will never regret it.

Boys:-Since writing the above I found the estimated cost of feed. ing our cattle here at this farm the year before we put up the silo and the year after, which bears out the statement I have always made that we could burn the silo and rebuild every year and be money ahead.

\section{Year Before:}

Seventy-five head short horns-from Dec. 1 to May 10 , consumed 2,500 bu. corn at $70 \mathrm{c} \ldots \ldots \ldots \ldots \ldots \ldots \ldots 1,000.00$

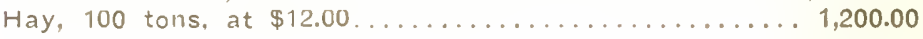

Year After We Built Silo:

$\$ 2,200.00$

Cost of 10 acres corn silage, 65 bu. acre, 40 c per bu. . \$ 260.00

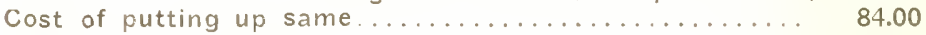

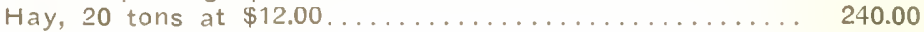

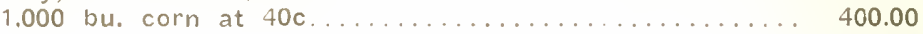

$\$ 984.00$

Balance in favor of the Silo, \$1,216.00.

That looks too good to be true, but when feed is high that is when it pays, regardless of being able to feed frosted corn to an advantage.

M. DOUGLAS,

Flat Rock, Ind.

\section{SECOND PRIZE ARTICLE}

It is a gineral conceded fact that ensilage is an excellent feed for dairy cows, but that it is also a grand feed for beef cattle is not so widely known.

W'e have used an Indiana Silo in the feeding of beef cattle for several years with most excellent results. Two years we fed large steers, and the remainder of the time light butcher heifers. I have at hand the exact figures for last year's feeding, and will give them, as last year was about an average year. Some years we made somewhat less and some considerably more.

The last of November we bought on the Chicago market a carload ( 30 head) of 510-1b. heifers. They cost laid down in Centerburg. all expenses paid, $\$ 3.22$ per 100 pounds. These heifers were fed ensilage 
morning and evening, and a little clover hay at noon the entire time until sold, receiving no other feed. On May 3 we delivered them to the Howell Provision Co., Newark, O., at the scales one mile from our place. They weighed 652 lbs. each, and we received $\$ 4.75$ per 100 pounds. Below I give an itemized statement of costs and receipts.

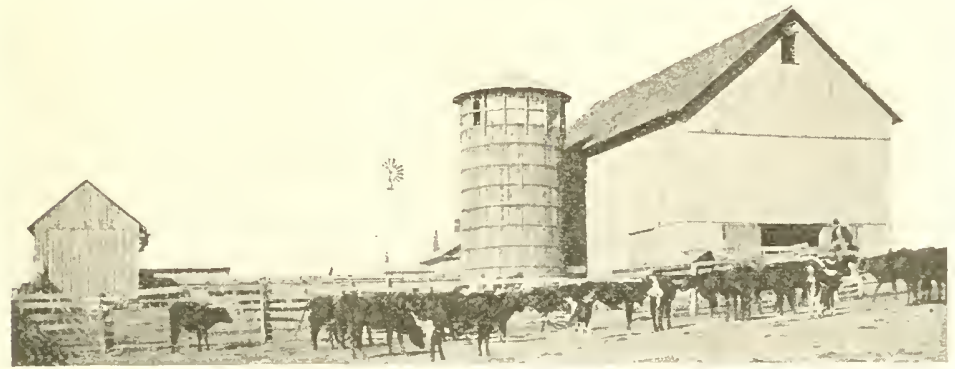

J. Paul Long's Calves, Centerburg, Ohio.

Receipts :

19,560 lbs. cattle at $\$ 4.75$.

$\$ 929.10$

\section{Costs:}

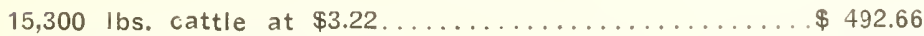

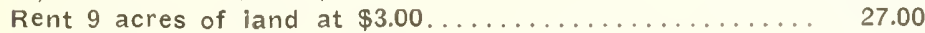

Plowing 9 acres of land at $\$ 3.00$ per day ............ 18.00

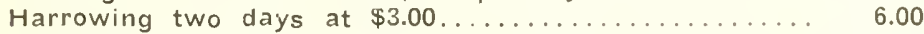

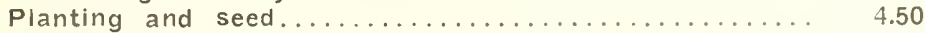

Cultivating three times at $\$ 3.00$ per day ............. 12.00

Use of engine $11 / 2$ days at $\$ 8.00 \ldots \ldots \ldots \ldots \ldots \ldots \ldots \ldots . \ldots \ldots . \ldots \ldots$

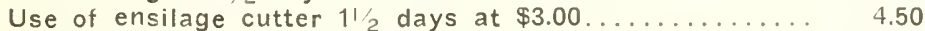

Slack coal for engine......................... 1.00

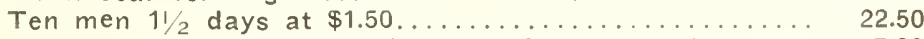

Board of men and teams $11 / 2$ days at $20 \mathrm{c}$ per meal...... $\quad 7.80$

Total costs.....................\$ 607.96

Receipts .................. 929.10

Costs .................... 607.96

Net profit.

$\$ 321.14$

It will be noticed that I do not charge anything to clover hay eaten by cattle. This charge is fully offset by ensilage fed to milch cows and horses. Neither do I charge anything to labor of feeding cattle or interest on money invested in cattle, silo, barn, etc. This charge being entirely offset by scores of loads of rich manure hauled out on land. I fed the cattle practically all the ensilage they would eat, so they ate but very little hay. Ensilage fed to dairy cows will, of course, make a larger gross profit than when fed to beef cattle, but also entails a much larger amount of labor.

This much net profit from nine acres of poor corn (the land having been in corn four years successively), seems almost impossible, but is rendered possible by two facts, first, when fed through a silo the entire 
corn plant is utilized, there being no enormous waste as when fed from shock, and second, when put in an Indiana Silo there is no waste of ensilage at sides and doors as there is in many other silos of inferior construction. The experience of silo users in this neighborhood is that an Indiana Silo will a great deal more than pay for itself every year it is used in net profits.

J. PAUL LONG,

Centerburg. Ohio.

\section{THIRD PRIZE ARTICLE}

INidaxa Silo Co., Anderson, Ind.

Gentlemen:-l have two Indiana Silos, and think they are a great help.

The value of silage over dry feed can be rated as almost double. Its importance rests upon its succulence; like grass, a natural feed, it keeps the animal in a healthy condition. maintains the vigor of the cow while producing a large flow of milk. It is economical because there is no waste, the stock eats it clean. The same amount of land will produce mora silage

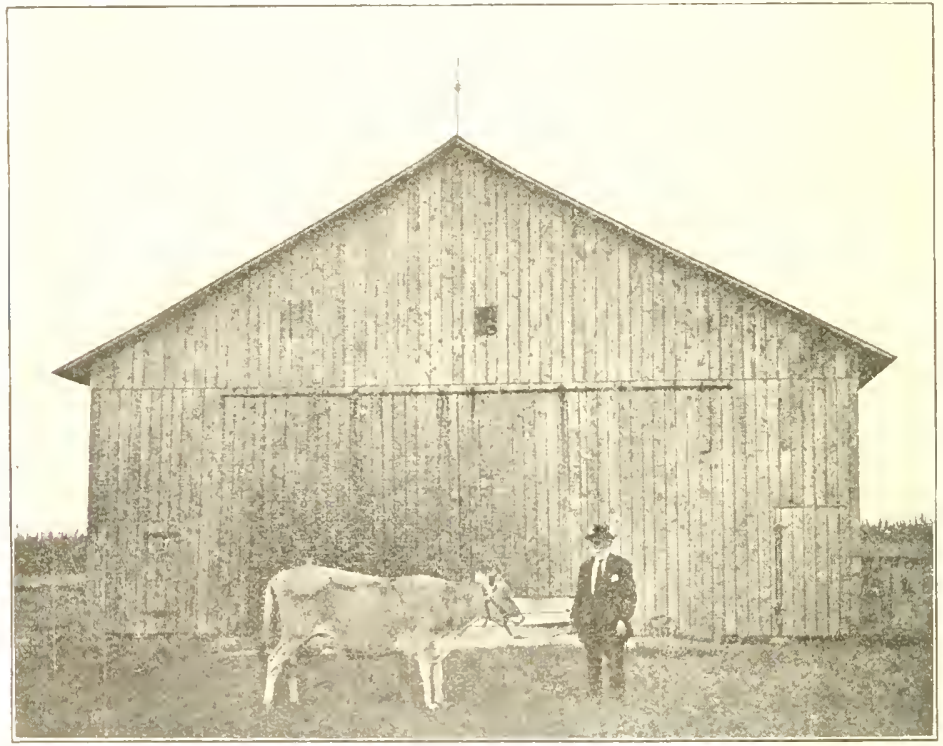

Isaac L. Jeffries and One of His Favorites.

than any other feed. There is no loss in curing. It adds fertility to the soil because the manure is richer than that produced from the dry feed.

Its greatest value is shown in dairy lines. By having two Indiana Silos filled with corn ensilage to feed my cows, I make as much butter in the Winter time as I do in the Summer when the cows have grass to eat. For rearing calves it is without an equal.

Of the crops that are best for silage to my mind, corn is best. To get the best results from corn for silage it should be cut when the grain is going out of the milk state and is beginning to harden. If cut too green 
the silage is apt to become sour; if cut over-ripe it will be hard and woody. An acre of corn will produce from 15 to 20 tons of silage.

Ensilage will lose its value if allowed to mold which will be the case if unused for a number of days. Therefore, it is best after beginning, to use at least two or three inches each day. More cows can be kept from a given acreage, if fed ensilage, than from one-third more acres if fed dry feed.

Until the feeder can find a food equal to corn ensilage for even twice the cost, he had better seriously consider the silo. Under present conditions I beiieve that one-fourth of all the farmers keeping stock in the corn belt will find the silo an economic acquirement. An acre of corn put in the silo I value at $\$ 55.00$, while the same corn standing in the field and husked in the usual manner I value at $\$ 27.00$. This is accounting for all cost of harvesting. Then an acre in the silo is worth two in the field, or putting it another way the silo doubles the value of the corn crop.

I am in a company that owns a cutter, and, in filling, we have one man to drive the harvester, six teams to haul corn, four men in the field, three in the silo, and two to feed the cutter. When we have to hire help we pay $\$ 2.00$ per day for the engine and men to run it we pay $\$ 5.00$ a day. If we had to hire all the help it would cost $\$ 37.00$.

We filled my two Indiana Silos 12 by 24 and two-foot basement in ten hours. Sincerely yours,

ISAAC L. JEFFRIES,

Westfield, Ind.

\section{FOUND PROFIT FEEDING DRY COWS.}

Indiana Silo Co., Anderson, IND.

Gentlemen:-I wanted a silo for years. One day the Agent for Indiana Silo came to my house, the Wild Rose Farm, and I became a purchaser. I ordered a Southern Pine Silo, $16 \times 30$. Before the order was filled I changed it to a fir silo at an increase of $\$ 100$ in cost and have never legretted the change. We were a little late in getting our silo up in 1308 , and were further delayed in getting cutfer. All the corn and sorghum that was green enough for ensilage was not sufficient to fill the silo more than two-thirds full. We began feeding at Christmas. The spoiled silage on top was less than six inches. We had topped much green sorghum. We fed a lot of steers, calves and dry cows. The cows cost $\$ 32.00$ a head. In February we sold the cows at 5 cents and they averaged $\$ 60.00$ a head. The calves were sold at public sale on March 16 and made as high as $\$ 38.00$ per head. They were ied all the clover hay they would eat at noon and ensilage night and moruing. The calves cost an average of $\$ 19.00$ in September.

We also fed young mules and work horses. After the sale we fed our cows until May 15, and they made little change when going on big grass.

In 1909 we cut $10^{1 / 2}$ acres of heavy corn, which filled the silo to the top. We again topped with green sorghum, and the filling was done in a day and a half. The whole cost for 140 tons was $\$ 400.00$. (Our foundation is 4 feet deep and adds considerable to the capacity.) Having sold the farm, to give possession February 1, we put in Jersey cows and heifers and began feeding ensilage on Thanksgiving or a few days before. They were two weeks getting on full feed. February 1 st we held our sale. The Jerseys made a profit of $\$ 15.00$ a head on forty head, and half the entire lot of silage was left and in the best condition. So that we count that the silo paid us handsomely. We are now looking for another farm with an Indiana Fir Silo or one on which to build such a silo. I think it is one of the best investments a farmer can malie.

HOWARD H. KEIM,

Ladoga, Ind. 


\section{INCREASED PROFITS 150 TO 200 PER CENT.}

INIMANi Silo Co., ANDERSON, IND.

My Deal Sirs:- I have used an Indiana Silo for six years and find its use profitable in several ways. For the following leasons I freely recommend the Indianit Silo, mannfactured by the Indiana Silo Company, of Anderson, lind.:

First: For their convenience in leeding. It is much more convenient and comfortable and expeditious than to go out in the fields in cold, stormy weather to haul teed.

second: I find that the use of the silo avoids the loss in the two changing periods i. e., from grass to dry feed in the Fall and dry feed to grass in the spring. This is becanse ensilage is a natural, succulent feed similar to grass. I always had a heavy shrinkage at these periods before I bought the Indiana Silo.

Third: Before I bought the Indiana Silo, my glound produced 35 to 40 bushels corn per acre. Now it produces 60 to 75 bushels per acre. Potatoes averaged about 100 bushels per acre. Now I get about 200 bushels per acre. These results were brought about by the different and better methods of handling the manure. Formerly 1 fed in the barn lot, and the coarse manure was not available for fertilizing for a year or more. Now, by using a silo I am enabled to produce more manure with same number of stock and haul it direct to the field. Hence the principal elementsnitrogen, phosphoric acid and potash, are not bleached out and washed away. I consider this quite an item.

Fonrth: Since using the Indiana Silo I can carry about twice the number of stock on the same amount of tillable land-about 90 acres, and do it with less labor. At the same time the fertility of the soil is increasing.

Before I bought the Indiana Silo I carried 15 to 18 head of cattle, 3 or 4 head of horses. Now I carry 30 head of cattle and 7 head of horses and some other stock

Filth. I find that my cattle go on grass in the Spring in much better condition than they did before using the silo.

Sixth: Last, but not least, my profits have increased from $150 \%$ to $200 \%$ more than by the old method of leeding.

\section{MARTTN KULL,}

Moundsville, IV. Va.

P. S.-By feeding clover hay with the silage, my cows produce as much milk as they do on grass.

M. K.

\section{GRAIN SAVING PAYS FOR SILO.}

INDixi Sulo Cu., Axumisux, IXil.

Gentlemen:- l became interested in a silo in the summer of 1908, and visited youl factory with several of my neighbors and gave my order for a $14 \times 24$ before I left the factory. I had more than satisfactory results with its feeding that fall and winter and find it of equal value for simmer feed. From Jan. 1st, 1909, to Jan. 1st, 1910, I produced from an average of ten "oivs f1, $1 \times !$ gallons of milk, for which I received $\$ 1,291.28$ at my barn. It does not take onp-halt the glonm lised since I have my silo. I am satisfied the silo will pay for itsell pach vear.

Since feeding ensilage I can safely say that I save 3 Ibs. ground feed per day lor ten cows which for 365 days would equal 10,950 pounds which, at $\$ 1.1: 1$ ler 100 poumcls would net me a lrofit of $\$ 109.50 \mathrm{in}$ a year in grain alone, and that does not near tell the story. I take off my hat to a good bunch of cows feo from an Indiana Silo and properly cared for by their owners. Yours truly,

JNO. E. HOLLINGSITORTH, JR.,

New Angusta, Ind. 
INDIANA Silo Co., ANDERson, IND.

In the early part of 1905 I began to investigate the different kinds of silos, both those made by manufacturing concerns and those put up at home. At that time I had never seen an Indiana Silo, but I saw their ads in reliable papers, and, after some correspondence, I decided that was the silo for me, and 1 have never had reason to change my mind.

I bought a 12x30 long leaf yellow pine with twelve hoops. The cost of erection was almost nothing, something less than $\$ 5.00$, everything fitting perfectly or as one ol my men said, "You would think that silo had been put together a dozen times." It may not be true everywhere, but here in my locality the greatest objection to silos is the cost of filling.

My experience is that it is the cheapest way I could harvest corn. Of course I know we work our corn up a great deal closer here in Pennsylvania than through the West, but I also know it would be to the interest of the farmers everywhere to malie better use of their corn, especialty the stover, and this can hest be done by use of the silo.

One year with another on my soil and in my climate it takes about six acres of corn to fill a silo of this size ( 80 tons). The first year I hired all my help, including teams, and it cost $\$ 40.00$ to fill. Since that I have changed more with neighbors and have filled as jow as $\$ 20.00$ cash. Can any farmer prepare any other lind of leed for his stock at from 25 to 50 cents per ton. Compare this with husking, shredding, cribbing and grinding. In the latter case you lose the green, luxuriant quality of the fodder, also, the losses by weather, mice and extra handling. Some of my friends have said to me, "I don't see but what you buy as much mill feed as you did before you bought the silo." I think I buy more, but I keep more live stock and get enough better returns lrom them that I can well afford to buy. I make more money and the farm has more manure. One should not forget that when you fil. a silo with coln its contents is corn, and to get the best results you must add the necessary protein to balance the ration. All silage is not a good ration any more than corn meal, and corn stalks fed alone are a good lation, but you can well afford to make the necessary addition. My home feed dealel says he has noticed that when his customers with silos come to town for feed they always have the money to pay for it. All in all I don't think any farmer with live stock and corn can afford to do without a silo, "An Indiana Silo."

On September 11, 1909, fire destroyed my barn, silo and feed, but the plans are made for another barn, and that barn will have a silo. and that silo will be an Indiana.

\section{N. L. KINGSLEY, Edinbol'o, Pa.}

\section{SILO SAVES TEN TONS OF HAY A YEAR.}

\section{INIIANA SILO Co., ANDERSON, IND.}

Gentlemen:-Yours receiven asking how I liked my silo. I got it in 1907, four men set it up and had one hoop on in $3 \frac{1}{2}$ hours. I consider it saves me 10 tons of hay erery year. The first year hay was $\$ 15.00$ a ton. That was $\$ 150.00$ saved, in 1909 it was $\$ 10.00$ a ton, that's $\$ 100.00$. In 1910 it is $\$ 12.00$ a ton, being $\$ 120.00$ saved. In the three years it saved me $\$ 370.00$, or about that. In 1909 I filled twice and opened Oct. 1st. Used about half and filled again Nov. 24th.

I am very much pleased with it and would not sell it for anything if I could not get another. Yours for success, 


\section{SHOULD CONCERN EVERY FEEDER.}

Dear Sirs:--To whom it may concern, and it ought to concern every cattleman. every dairyman and every farmer who raises a good many Inimina Silo Co., ANDERSON, IND.

cattle.

The silo I bought of the Indiana Silo Co. last Fall has lar excelled my expectation. I filled it with corn to the top, and left it stand until about the 10th of November, then opened it and began to feed it, and must say that that was the best feed I ever fed to dairy cows. My cows did better this Winter, both in milk and in flesh, than they did last Summer on the best of tame pasture. My cows are all in a good shape for beef. Have sold tow1 dry cows ior beet, and could have sold all that I have at a large and long price, and I must say that it was the ensilage I fed to my cattie that put them in that shape. I used to think I could feed cattle, but I linew nothing until 1 rected a silo.

1 an so well pleased with my silo that if I ever move to a farm thai has no silo on, I will erert one as soon as I can have one filled, or, if 1 should enlarge my dairy so I should need another, I surely would erect another Indiana silo.

I must say, Hurrah, for the Indiana Silo co., The Manufacturers, and its users. Thanking you for last, favors, I am, Yom's truly,

\section{U.S.KRAFT,}

Akron, Ind.

\section{WHAT A GOOD COW WILL DO.}

Indiand Silo ('o., ANulisox, IN1).

Gent!enen:- Yours of the $14 \mathrm{th}$ at hand. l berewith give you a few facts in regard to my silo. I am very enthusiastic over feeding silage to ritilk cows. In the first place I save $25 \%$ in halvesting expense, and I figure I save to\% in the corn crop as the cows eat every bit of the crop. 1t is the most palatable leed I ever put belore my cows. It keeps their digestion pellect and enables them to digest and gives them a much better apluetite for roughage, thereby giving me a much larger flow of milk. For example: I have one cow eleven years o:d that has always given a good fiow of milk, but three vears ago l bought an Indiana silo and she has nearly doubled ber flow of mill. [p nutil two years ago she never gave ove 7,010 lounds of nrilk in one year, but in 1908 she gave $10,1828-10$ pouncs, and slie is doing about the same this year. Her average test for 1908 was 1 ; butter fat, making $40731-100$ pounds.

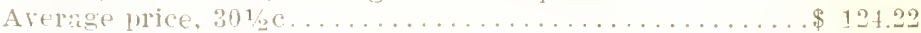

Arld to this $85 \%$ of skim milk at 100 rel 100 , makes

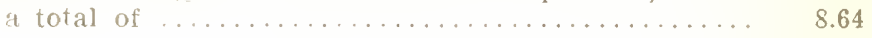

$\$ 132.86$

This is nore than coub'e the amount I evel got from her before I comruenced feeding emsilage. I keep 10 to 14 cows, and this is the experience with all of them. 'The past ycar I have milked 10 cows and they brought for milk at our creamery, $\$ 1,043 . \$ 1$, besides the slim milk furnished. Also, milk lor two families, and made our own butter for six months. 1 weigh all of my milk and keep a record of each cow and know just what each cow is doing all the time. I could not think of keeping cattle and dairy cows in particular, without a silo filled with good mature corn. Yours very truly,

W. W. KNAPP, Watervliet, Mich. 
IndiAnA Silo Co., ANDERSON, Ind.

Gentlemen:- In reply to yours of the 22 nd inst. I wish to say your silo is about one of the best on the market. We bought one of you two years ago. Year belore last we did not nise it on account of not having corn enough to fill two, but this year we filled it to the top. When we started to feed this fall we were surprised at the small amount of decayed matter at the top. There was not more than two inches while on the other silo $w$ z used to have from six to fourteen inches. We think that the Indiana Silo is tighter fitted so as to exclude all air. Now I will give some profits which we made by buying the silo.

Truthiully written three years ago before having two silos we raised 22 acres of corn. It was good corn, giving from 50 to 75 baskets an acre. Welı we got half of it shocked before the frost, part of it being put into the one silo. The rest was frozen, and we shocked it as it was. We husked it and put the corn in the crib, and the stalks in the barn. In the spring after feeding it all winter we found that most of the stalks in the middle of the mow had decayed, and the cows would not eat half of it. The corn in the crib was the same, half of it was worthless, as it had decayed. Now what I want to say is that if we had put this corn and stalks in a silo, we would have had twice as much profit from the feed. We have 12 head of milch cows and 11 head of young cattle, and this year we have all our corn in the two silos and nothing went to waste.

I believe farmers can just as well have two silos and raise a little ear corn for own use and put the stalks in a silo than to have one and let some of it go to waste. A few farmers in the vicinity have corn shocked in the field yet standing in the snow. Half of this goes to waste before spring, and is bad feed for a dairy cow. Yours truly,

\section{NICHOLAS KREUZE,}

Hudsonville, Mich.

\section{SEVENTY-SIX DOLLARS PROFIT IN ONE MONTH.}

\section{Indiaxa Silo Co., Anderson, Ind.}

Dear Sirs:-In regard to the Indiana Silo, we think it is one of the best on the market. We bought and put up one of your silos in 1908. It has more than paid for itself in leed saving. We will give you some exact figures. Our largest milk check before we bought an Indiana Silo for any cne month from 15 cows was $\$ 150.00$. For December, 1909 , we received a $\$ 183.50$ milk check, fed 2,200 lbs. of milk to calves, used $300 \mathrm{lbs}$. for table use. We got $\$ 1.70$ per hundred for milk, which would foot up $\$ 226.00$ from 15 cows, a difference of $\$ 76.00$ when using silage from an Indiana Silo. $\mathrm{W}^{\gamma} \mathrm{e}$ are breeding and raising full-blooded Holstein cattle. We keep from 35 to 50 head of cattle on hand and our silo, $14 \times 30$, holds enough to feed them through the winter with a few cow peas. We save at least 400 bu. of corn each winter by using an Indiana Silo. At present prices, 60 centa per bushel, this is $\$ 240.00$. Our young cattle do not get any grain except what they get in silage, and all look sleek and fine. Before we got our silo we fed about $\$ 50.00$ worth of mill feed per month, but now about $\$ 15.00$, a saving of $\$ 35.00$ per month.

The Indiana Silo is one of the greatest feed savers that we have tried. We don't see how any farmer with as many as 10 good dairy cows could afford to be without one. Yours very truly,

G. W. WISE \& SONS,

Beaver Creek, Ill.

P. S.-We will send you a photo of our cattle in a few days 


\section{THIRTY-SIX CATTLE ON THIRTY-TWO ACRES.}

Inmaxa Silo Co., AxDerson, Ixt.

Gentlemen:- In reply to yours of the 15 th in regard to what the silo has done for me, will say if I can help others I am glad to do so.

Enclosed you will find photo of barn and silos.

I am on a farm of 32 acres which I purchased in 1905. My first crop was rather poor. The next year it was better. I kept 12 cows and 2 horses and had to buy about $\$ 100.00$ worth of rough feed.

For years I had wanted a silo, so the fall of 1907 I bought my first silo, which was $12 \times 24$. It took four acres of corn to fill it. Seeing I had lots of leed in sight 1 bought 12 mole cows, making 24 head, and 3 horses, and bought about $\$ 151.00$ worth of rough feed. I was so well pleased with the silo that the next yeal 1 jut up the second ludiana silo, this one $14 \mathrm{x} 30$. That tall and winter 1 had 24 cows, 1 bull and 11 heifers, all on full feed, with my 3 horses, and bought only $\$ 20.00$ worth of rough leer. At present I have 16 cows, 16 heifers and 1 bull on full foel and will have plenty feed to run until March 15, then will sell my heifer's and rows for the summer. So you see I have doubled my dary, besides the feeding I am doing, and raising all the feed on my little farm excut some mill feed, which all dairymen have to buy.

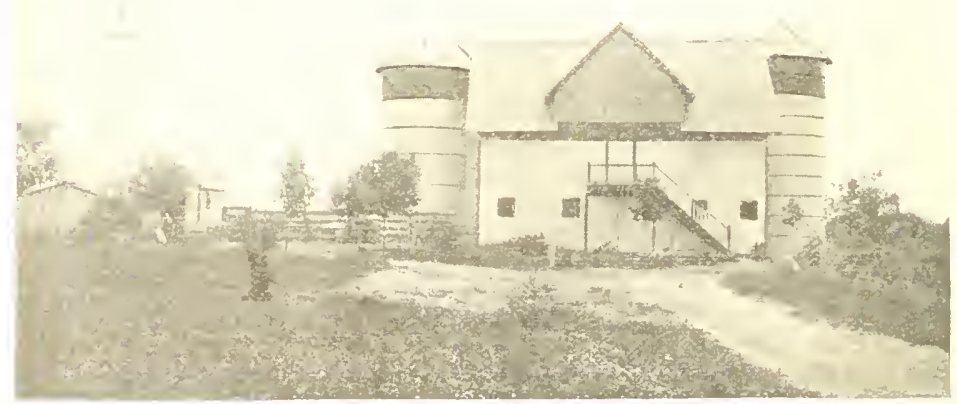

Barn and Silos on Mr, Draper's Thirty-two Acre Farm.

I consider the silo the only protitable way to handle a com crop, either for milking or foeding. The heilers which l fed last year did splendidy. Matle a gain of about zon lbs, in nuety-five days on silage alone. They' cost mo is cenls pel 1 h. and sold for $\$ 5.20$ per hundred. The ones I am feeding now are loing fine. They look like June grass-fed stuff.

In conchusion, f will say to the men who are in doubt about building silos, go antad and buy one, and buy one large enough, and the Indiana Silo, of course. Yours very truly,

IV. E. DRAPER,

IVayne, Ill. 


\section{A VETERAN'S EXPERIENCE.}

Ividaxa Silo Co., ANDERson, Ind.

Dear Sirs:-You's of the 19th at hand. Have not the least idea of getting prize. Am glad to have a chance to give my views and experience with my Indiana silo. Have filled three times and don't consider the silo oved me one cent after two year's' use. Can't give figures, but have been leeding stock all my life (am now 60 years old), and have always kept abreast with new modes for feeding grain and fodder. Have been shredding for a number of years, and think I know pretty well about how far the feed goes in different lorms, and the result upon the stock of the different ways of feeding the coln and fodder.

After going through the first winter in feeding silage, was convinced that is the best way to handle the feed. Always in feeding the dry feed my stock would get restless as Spring approached, and if not watched close, would be breaking out for a bite of something green. Since feeding silage have no trouble of that kind. If were younger would have another and feed silage to all kinds of stock.

I put my silo up in 1907. Then there were very few in this vicinity, not more than four. I think since then there has been about twelve put up in this one neighborhood, and I think one or two more years will see one on nearly every farm. Would say, however, some of the silos are the Uhio, not all Indiana. Think you can see by what I have written in an off-hand way that I am well pleased with my silo and wherever I can will speak a good word for you.

Hoping for a prosperous year and that your sales will double, I remain, Very respectiully yours,

BEN KIRBY,

Bloomington, Ind.

\section{CONTENTED AND HAPPY.}

Ixdiana Silo Co., Axpelisox, IxD.

Gentlemen:- In August, 1908, I erected one of your silos, 12 x 30, and put in about six acres of fairly good corn. I have no way of weighing so cannot give exact figures, but kept 16 head of cattle for six months. Cattle, hogs, hens and horses are quite fond of it. I never had stock do better on so little grain before or cows pay so well as they have since I have thə silo. I have filled it again in fall, 1909, and am having my stock do even better than evel before. Cows that came fresh in the fall are now milking 30 to 40 pounds of milk ler day on just every day ordinary feed and ensilage, with two or three quarts, or five or six pounds of feed per day.

February $1 \mathrm{st}, 1910, \mathrm{my}$ milk checks have averaged about an evell $\$ 25.00$ per week for the winter lrom seven milk cows, at an ordinary milk station. Before I put up the silo my milk checks averaged about that per month. I had one cow that did not make goor in milk, so I fed her right along and sold her tor beef for $\$ 4000$. My brother sold one for $\$ 50.00$ for beef a little later, and others evell better. Now, who ran do that with dry feed?

Farmers that are satisfied, contented and happy are those with Indiana Silos well filled with good ensilage. Stock never stops growing in winter to wait for spring. Milch cows do not have to spend all their time and strength pressing dry hay and corn fodder into a small amount of milk, but, like their master, are contented and happy. The people that have no silos are the ones that say that dairying doesn't pay. No wonder it does not with feed way out of sight, unless you have some nice ensilage to go with it. Yours, GEORGE HUBBS, Kirkville, N. Y. 
Indiana Silo Co., Anderson, Ind.

Deal Sirs:-I have been in the dairy business for nine years, and I was for seven years without a silo. Two years ago I bought a silo $18 \times 24$ from you, which I found in a good shape and it was very easy to set up. It was also just as you represented it to me. The planks in the silo were No. 1. I can honestly say to you that the first seven years of my dairying I did not make enough to pay my expenses out of my cows, as feed was too high to buy. I bought three tons of bran and hominy meal altogether in a month, and this I fed to about 24 cows. Since I have fed ensilage I am only

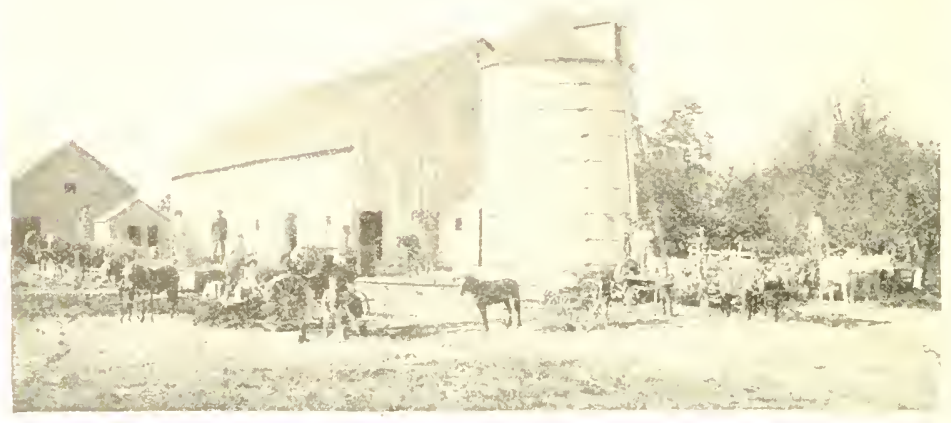

Filling Frank A. Hinners' Silo, Osgood, Ind.

feeding one ton of bran to 34 head of cows in the same length of time. That is two more cows than what my silo will feed for six months, but I think it will feed them six months. I opened my silo the first of November and I found the ensilage in it all right, and it will feed my cattle tiil the first of May. I can honestly say with my ensilage I am saving $\$ 40.00$ a month in grain feed, and I am sending more milk now than I ever did.

Ensilage is better than June pasture and every farmer should have au Indiana Silo, for it is a meney maker to him if he has many or few cows. I will also send you a photo of my silo and my silo filler with the crew with which I flled nine of your silos. Yours truly,

FRANK A. HINNERS,

Osgood, Ind.

\section{SIX COWS EARN MORE THAN TEN.}

INDiAnA Silo Co., ANDERSon, Ind.

Gentlemen:- We have an Indiana silo and are more than pleased with it. The silage is just fine. Made more money from six cows than we did the other years from 10 and the cattle looli so much better and we get a good deal more manure, which is good for raising better crops. We intend to have another silo in a few years, for they are fine. Yours truly,

J. B. KOESTER,

Effingham, Ill. 


\section{OLD TIMER PREFERS NEW WAY.}

\section{IndiAnA Silo Co., Anderson, Ind.}

Dear Sirs:-I received a communication from you people that you would give prizes for the best essay on silos, and I suppose that means in all its parts. Well, to begin with the first essential, I bought an Indiana Silo from the Indiana Silo Co., and it is good yet, and if I should buy another, I would buy the same kind. In putting up a silo the peop e should be very caretul to stay them well at the bottom and top. Our silo b'ew off the foundation in parts. However, we got it back without much trouble, but there were several others around here that blew down altogether, and they had quite a time to get them back up again.

Now, in filling the silo I think the people get in too big a hurry and fill them too quickly. There was a man in our neighborhood who got in such a rush to get his silo filled, and it sett?ed about eight feet. Now, he lost the space or the use of that much of his silo; besides, through here they charge $\$ 1.00$ a loot for $14-\mathrm{ft}$. silos, $16-\mathrm{ft}$. more, and $12-\mathrm{ft}$. less. Now, he paid $\$ S$ for that which he did not get.

We have our own cutter. We get a man with his engine to come and hitch on, and so far it has cost me $\$ 5$ a day. We furnish coal and water. We begin in the morning as soon as we can and finish next day. That permits it to settle over night. Mine settled $3 \frac{1}{2}$ feet.

Now as to the roofing, I prefer it without. We commenced to feed our silage three or four days after we filled the silo, so there was none wasted. Most generally there is from 18 inches to 2 feet moldy and spoiled and I have known of as much as 4 or 5 feet, and if it rains on it, it cools it off, tor it is bound to get hot. We fed cows and it made them give more milk and by so doing we utilized what otherwise would have been wasted. We did not feed so strong, and when it was about to get too dry and mold my boy put the hose on the porch pump and started the gasoline engine and pumped a lot of water on it that cooled it off and dampened it, for it will mold pretty quick. Now I think it should be kept in such a state that when you take up a handful and squeeze it, it will make your hand wet. I would not say that the water should run down over your hand, but that would be preferable to having it get too dry and streaks of mold get through it. I had some so wet we had to take a scoop shovel and shovel it up and haul it out in barrels. We led it in a long trough and it did the cattle as much or more good than any we ever fed. Now these are my reasons for not roofing, and often the rains or a snow saves the time of pumping water or of getting it up some other way, and if you will stop to think you will find that time is money, and a lot of it now-a-days.

I don't like to let this drop here. A man should go and examine his silo and see how it is doing. If it is getting hot and dry and dries down, it will be sure to get moldy streaks through it and stock will not eat it.

Now my silos are to the north and the feed room extends south, with a track down through the center. The boy fills the car with silage, runs it to the south end and feeds back, by so doing the track is clear all the time and he doesn't have to pass over the si'age with his feet, ur cal either. Now the quantity for steers about 1,200 lbs., 21/2 bushels full, twice a day; for milch cows, three-fourths as much as for the steers, with some cotton seed meal and bran. Our cattle are ravenous after it. The horses all like it. The hogs like it, and I am told the sheep like it. Now, first and last, if you want your stock to eat it well and do well on it, keep it free fronı mold.

I have heard of people cutting cow peas and putting in and cutting clover hay and beans, and various other things, but according to my judgment there is nothing so good as corn. The time to cut the corn to fill it, 
I think, is when the corn is ripe enough so that the grains are glazed over. Respectluly submitted, with many good wislies for your Silo Company,

\section{JACOB HENDERLICK,}

Petaskala, $\mathrm{O}$.

Now, Old Somny, I an 72 years old. This is the first letter I ever wrote of this kind, and not very many of any lind; but you old Hoosiers come out here and see me and I will talk to you until you get tired.

J. H.

Gentlemen:- I got your letter, rear a part of it and what I thought, laid it on the cupboard and proceeded to read the other news. I thonght the matter over and concluded I would write, but I only could find the envelope. The tetter had tallen, scooted under the cupboard and this morning one of the children found it. Now I had written my letter of my experience and what I have learned about the silo. Now since the letter is found it tells me you want the exact figures of profit shown by the use of silos. That I camnot tell, for I have not a scale on these questions. I will honestly give you what I can on the subject.

The last week of March, 1908, I got a carloat of cattie from Chicago. We pastured through the summer, led silage about six weeks in the fall, malle a gain of 452 pounds to the steer. Feb. 1, 1909, 1 got a carload. We fed some silage in spring and some in fall, made a gain of about 400 pounds to the steer. The first we sold at $4^{1}$ cents per pound, realizing $\$ 19.12$ per Leat. The last lot we reafized about $\$ 20.00$ a head on 32 cattle. The most of our silage is fed to milch cows with other feets. Now all stock like it and do weIl, to what extent I camnot tell. Now if I am knocked out I am knocked out, that is all, but don't you go to mblishing anything that is misleading, for our govelnment puts out reports that are wrong for I was misted to the tume of $\$ 300.00$ two years ago, and last spring about $\$ 200.00$ though agricultural leports. Respectfully,

J. HENDERLICK.

\section{KEEPS THREE TIMES AS MANY CATTLE.}

Ixdiat Silo Co., Anderson, Ind.

Gentlemen:- In this zuth-century agf of agriculture it is necolless to say that the silo is as necessary an adjunct to every farm with a herd of eight cows as the centrifugal sefarator.

I am sad that I am able to say, and say it truthfully, that before I erected a silo I was able to keep only one-third the numbel of milk cows that 1 an able to keep now. Since erecting an su-ton Indiana Siio I am able to sucressfully teed, and with profit, lrom 35 to to head of cattle for 6 to 7 monthe My herd of cows paid for my silo the first six months of fecding, in the saring of mill feed, whrpeas I uced to use from 10 to 12 tons of bram, z to 4 tons of giutem, 1 to $z$ tons of rotton seed, costing in round numbers, \$4ril.nu. I now fefel silage, 1 to 2 fons of bran and 1 ton of cotton seed, bran and cottou sceel costing alont \$.t6.00. Counting silage worth $\$ 2.50$ per tou, s0 toms would be worth $\$ 2100.140$, maling a total of $\$ 256.00$ for six months, ac against $\$ 4.0 .110$ without the silo, a siving of $\$ 194.00$, enomgh to build me another goud so ion Indiana silo, to say nothing of the better condition in which the cows are, and the frerformance at the milk pail, the sleekness of the cattle and the size of my momure pile. I feel that my silo is the be st investment I have evel made and $1 \mathrm{am}$ looking forward to the very near future when I shall elect another silo. Yours truly,

\section{F. I. HIEIM.}

Wooster, $\mathrm{O}$. 


\section{SAVES 900 BUSHELS OF CORN.}

Indiana Silo Co., Aximlison, Ixil.

Dear Sirs:- In answer to your cireular letter will say that I can give you some lacts as to what my silo has done for me.

On Decembel 1, I weighed up 54 head of cattle that averaged 982 pounds, started them on a light ration of snapped corn and hay. On December 23 l opened my silo and began feeding these cattle silage and cotton seed meal, gradually increasing until they were getting 35 pounds of silage and 4 pounds of cotton seed meal per head daily, and, at the same time, changing l'om snapped corn to broken ear corn and shelled corn until they were getting $S$ pounds per head daily oî shelled corn. They were fed this ration of 35 pounds silage, 4 pounds cotton seed meal and $\delta$ pounds of corn and all the briglt timothy and clover hay they would eat, which was very little for 30 days. Then I began increasing the shelled corn until they were getting 14 pounds, which was all they would eat. On March 15 I weighed the cattle again at an average of 1,254 pounds, a gain of 272 pounds in 105 days, or a daily gain of 2.59 pounds. I am satisfied that to have made the same gain without the silage it would have taken 15 bushels of coln a day more, for about 60 days until ! increased the corn to 14 pounds, which would be 900 bushels at 50 cents or $\$ 150.00$.

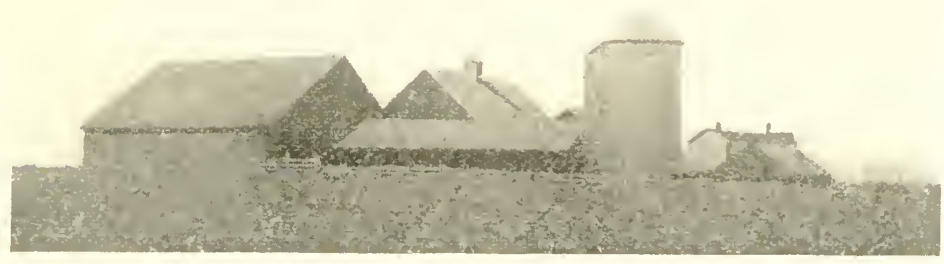

E. E. Heil's Establishment.

My silo which is $16 \times 30$ cost me complete, foundation, root, paint and all, $\$ 300.00$, which leaves a balance of $\$ 150.00$, alter paying for the silo in one year. The $\$ 150.00$ balance, what I leed to other cattle and what will be lett alter leeding these eattle until the middle of April will give me market price for the corn put into the silo, which was about 600 bushels. Therelore, you sec I have practirally paid lor the silo out of the stalks that would have been wasted and a nuisance in the field in the spring. to say nothing of the number of tons of $\$ 10.00$ hay saved. On March ¿2 one load of the poorest cattle were sold at home for $\$ 6.50$ per hundred. On April 4 the test load was sold at home for $\$ 110.00$ per head or close to the $\$ 8.00$ mark. I still have the other load and they are doing fine.

Besides what was fed to the above cattle, fcur cows and two yearling heilers were fed 25 pounds per head daily 1or 60 days, with an increased fiow of milk in the cows, and the heifers were ready for the butcher's block at any time if I had desired to put them there. And still enough silage to feed 45 head of stock cattle a daily ration of 10 or 15 pounds until the 1st of Nay.

In conclusion I would say that by the use of the silo you can make a maximum gain at a minimum cost. Yours truly,

E. E. HEIL,

Pleasant Hill Stock Farm, Garrison, Iowa. 


\section{A CHEAP AND NUTRITIOUS FEED.}

Indiaxa Silo Co., Andersor, INu.

Dear sirs:- The problem of a cheap and uutritions feed for dairy cows and other linds of stock as well, has been solved by the introduction ol the silo iol $^{*}$ the storage of the different crops grown on the farm, particularly field corn, sugar cane, the large growing clovers and cow yeas. Field or ensilage corn is preferred on account of the enormous amount grown per aere, as compared to the shorter growth crops, and is also considered better alapted to all linds of stock.

Ensilage is pre-eminently the best feed used by the stock raiser or dairyman lor the reason of its cheapness, quality and convenience combined. No other leed can be stored more conveniently; no other feed is richel in quality as compared to bulk, and no other feed is cheaper, when six acres of corn, produeing 60 bushels ol corn per acre, will make 75 tons of good silage stored in an Indiana Silo, making 150,000 pounds of feed, costing not more than $\$ 1.50 \mathrm{per}$ ton, enuugh to feed 25 cows 200 days at a cost of less than 3 cents for tach cow per day. There is no othel clop glown on the tarm that can compare with eorn silage stored in an Indiana Silo. There are other adrantages connected with feeding corn silage that will convince any practiced farmer or stock raiser that he should become the ownel of an Indiana Silo. The silo allows the farmer or dairymin to keep more steck on less acres, thereby increasing his protits and increasing the fertility of his lar'm.

To make it still more plain, the cost of feeding 25 cows 200 days with silage and enough bran would approximately be $\$ 350$. To feed the same number of cows the same number of days without silage, using crushed corn or hominy feed instead, would cost, not counting roughage in either test, apmoximately $\$ .500$, leaving a balance of $\$ 150$ in favor of the silo, allowing the feeder to keep one-third more stock.

The protits from feeding corn silage over the old way of feeding is still ineleased by the lact that stock fed with silage will consume less roughage than stock not fed silage. To the donbttul stockman or farmer, do not hesitate longer, but be the owner of an Indiana Silo, the best ever.

A. V. HIGHTSHUE,

(lejmont, Marion County, Indiana, R. F. D. No. 16.

\section{SILAGE FOR THE HENS.}

INDIANA SILO CO, ANTERSON, IND.

Gentlemen:- The silo I purchased of your company two years ago is $O$. K. I fed dairy cows from it the first winter and they did fine, but as our boys flo not like to help run a dairy I sold nearly all of the cows. One of our neighbors said to me, "Now what are you going to do with that Silo?" I told him I was going to feed the ensilage to the other stock. I find that the general farmier needs the silo more than a daiyman. We ale feeding ensilage to horses, mules, jacks, stock cattle, brood sows, fattening hoss, pigs, sheep and poultry. Om hens conmenced laying as soon as we began leeding ensilage. I never had brood sows in as nice condition as they are now. Te leed some coln and hay to our shepp, hint they do not seem satisfied until they get ensilagr. I harl one of my neighbors eome and see me feed. He was astollished to see how everything eats silage.

I think the Indianit Silo is the grandest improvement of the age. If I owned this farm I would bujld more silos. I would harvest all our coln crop that way. There ought to be silos on every farm in lndiana. Fours truly, EII N. CRAMER, Brooklyn, Indiana. 
Indiana Silo Co., Anderson, InD.

Gentlemen:- During the month of August, 1909, my $16 \times 30$ Indiana Silo was elected on a cement foundation with $3 \frac{1}{2}$ leet excavated. It is covered with grooved roofing. The filling occupied $1 \frac{1}{2}$ dass, Sept. 28 and 29. Feeding began Nov. 22 ard figures given are for a period of four months.

The statement below is made with no attempt to exploit silos, hereford cattle or ability of feeder to secure results. The estimates are from beel valuations with reference to gains. Viewed from the standpoint of the breeder, the net results are considerably greater, these catlle being mostly pure bred Herefords.

\section{VALUE OF EQUIPMENT, STOCK AND FEED.}

Silo complete with root and foundation, painted. . . \$ 300.00

Filling (making allowance lor cost of husking) . . . . . 60.00

15 acres corn, 700 bu., siloed at $50 \mathrm{c} \ldots \ldots \ldots \ldots \ldots . . . . .350 .00$

50 calves, weight November 22,360 lbs.; valued $\$ 4.50 \ldots \$ \$ 10.00$

28 cows ............................ $1,680.00$

Other Feed-10 tons clover hay, $\$ 100 ; 10$ tons baled altalia, $\$ 150 ; 100$ bu. oats, $\$ 40 ; 150$ bu. shelled corn, $\$ 75 ; 2 \frac{1}{2}$ tons molasses feed, \$65; other rough-

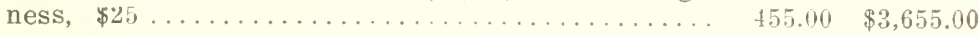

INVENTORY MARCH 22, 1910.

Silage fed to hogs and horses.............\$ 40.00

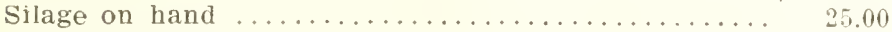

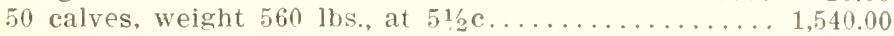

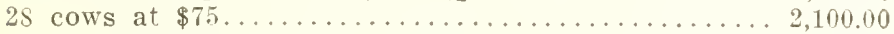

6 calves dropped during period................. 60.00)

Milk and butter from two cows................ 50.00

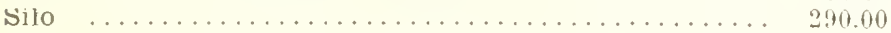

Net gain

$\$ 4,105.00$

$\$ 450.00$

The above statement reduces one year's silo experience to figures as

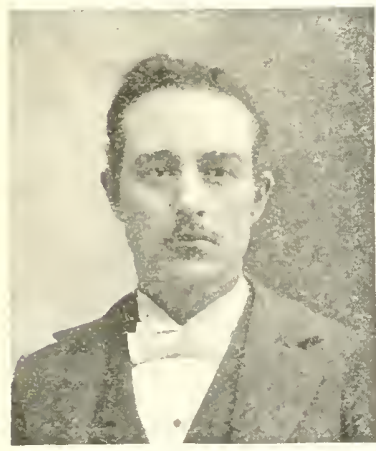

N. M. Leonard, Waukee, Ia. nearly as possible at this time. It would perhaps be considered only fair to charge part of the profits to other feeds used to supplement the silage. However, it will be observed that the amount used was so small that it alone would not nearly have maintained the stock, and the only profit to be derived from merely maintaining stock in the winter season is due to greater demand for stock cattle to go on pastures in the spring. This gain in value would not justify the expense if the good old summer time did not intervene. The figures given are rery conservative and it is safe to consider that if two farms identical in every other respect carrying similar amounts of stock of the above character for the production of fancy baby beef, the one with the 150 -ton silo will show an annual profit $\$ 500.00$ gleater than the other. 
This is based upon results obtained during a winter with 90 days sleighing, with temperature below zero one-third of the time, when fuel bills were double the average amount and hay scarcer than coal because of what was required for inel to keep up the animal heat. But a display of cold profits does not tell the whole story. The writer cared for this stock without assistance in addition to other stock and used less than half of his time. No hauling fodder in blizzards, chopping slocks out with an ax or miring in a sea of mud, no loss from gophers, mice or exactions of weather-just solid comfort scattering silage down a feed bunk 50 feet long coming up to the silo dool; feeding done without slipping in snow or mild.

The question is frequently asked, how does stock like it? Go ask the cattle. Their repty is eloquent in the pandemonim turned loose on both sides of the feed bunk. They thus proclaim, "Nothing like it," and bottom of bunk soon shines like a china plate.

A local drover was asked: "Tom, how do those cows look atter being wintered on silage and stubble?" "They look pretty dang good."

N. Mí. LEONARD,

Waukee, Iowa.

\section{FEEDS SHEEP ON SILAGE.}

INIMAXA SILO Co., ANDERSOx, IND.

Gentlemen:- In answer to yours of February 2, 1910, 1 submit my experience since the murchase of my silo in 1905.

I purchased an Indiana Silo in 1905 and filled same fall. Shortly after filling 1 traded larms, but reserved the silo and contents and was compeller to haul the silage five miles that winter. In the fall of 1906 I erected it on its present site. Did not keep accurate account of gains made, but was well satisfied with condition of stock at spring time.

In the fall of $1906 \mathrm{I}$ filled it again and fed to everything on the larm and bought a load of beef cattle. I led with good gain on ensilage and a small amount of dry coln and straw, keeping dairy cows off pasture until they had a good start in the spring. In the fall of 1907 I filled again, but this year did not get it all fed; had about 10 feet left over. At this time I rooted the silo, 1908, taking off what little had sloiled, filled in on top of what was lelt and hegan feeding about the middle of November, and re. filled again with ary loddel about December 15. This time used water on fodder. Added some Chicago steers, with the intention of leeding the silo empty in time lor grass, but with the silage and clover hay in five months the steers looked so good to the buyers that I had to let them go and still had enough silage to do 20 head of cattle to the loth of June, 19(1!). When my neighbor's' pastures were short and bare I was just ready to tum on pasture that was in bloom, and instead of using 18 acres for lastur", as I had planned, I nsed 10 acres and kept the 18 for hay; so after getting a good gain on about 40 head of cattle, fed 10 head of horses two feeds a clay, 13 sheep one feed per day, 22 brood sows one feed per day. This is loy the silo of $16 \times 24$.

In the fall of $1909 \mathrm{I}$ filled again and am feeding to dairy cows and 232 breeding eves, which are doing well on one leed of ensilage and one feed of alfalfa per day. Will have silage to carry them to grass in good condition. It costs ahout 75 cents per ton to fill the silo, not counting the corn, and the com that is put in it is doubled in value. The silo is so valuable I do not see how so many farmers get along witloul it, as I believe there is a rofit by the use of silage that is inestimable in the growth of all live stock. Yours truly,

EDW. E. HIATT,

Greentown, Ind. 


\section{SILAGE A HEALTHFUL FOOD.}

IndiANA Silo Co., ANDERsox, IND.

Gentlemen:- In dealing with the question of profits derived from the practical use of the silo on my farm I find it impossible to give them in tigures, as it is ted with other feeds, but will surely say I believe it to be most excellent feed for cows, fattening steers, stockers, brood ewes, fattening sheep or lambs. We also make it a practice of feeding it to our horses and colts in smaller quantities; also to brood sows.

It should be understood it is mainly used for ruminating animals. Under one roof we feed 9 head of horses, 40 head of cattle, 160 sheep,30 hogs, and I can safely say we don't have one sick animal for every ten my father had 50 years ago on one-quarter the amount of stock. A great amount of this difference I credit to the silo.

I consider the 12 or 15 acres of corn in the silo worth in dollars and cents twice that amount harvested in any other way. Why? Because we have the whole stock and ear cut when in full maturity, from the ground up. This, with the good effect it has on the animal to help other feeds do their work, is why I put this value on ensilage.

In conclusion, I might say something on filling the silo. In buying a cutter, be sure to secure a large size. Don't be fooled on any small machine. I prefer six men as cutters, teams with low rack. Put three men to cut for one wagon, each man take his row and cut and carry to driver, teams enough to keep cutters going. I like this way better than the binder. Last year six cutters liept the machine singing all the long day. Didn't stop fifteen minutes all put together.

If we make any change in the silo business it will be to build another one.

C. H. HILL,ES,

Bourbon, Ind.

\section{MORE PROFIT AT LESS COST.}

Indiana Silo Co., Anderson, Ind.

Gentlemen:- There are many things which have passed the experimental stage. One of them is the silo and the feeding of silage to various

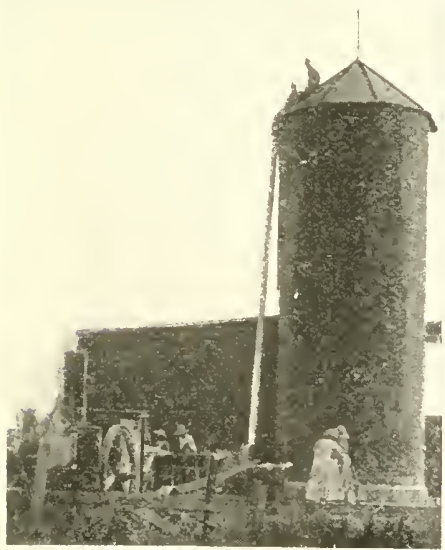

Filling Silo on Irish Dairy Farm.

turned $\$ 745.26$ from the creamery. kinds of stock and especially dairy cows. It is a happy combination for the dairyman. It combines cheapness in harvesting and storing, convenience III feeding, a much relished feed and one that takes the place of summer green feed during winter and dry times during summer.

Here are some figures showing its effectiveness as a milk producing feed. In the summel of $190 \mathrm{~s}$ we purchased a silo of the best cypress wood of the Indiana Silo Company. It was a new thing in our community. People came and looked at it as if it were a white elephant. It was filled during Septem. ber and opened November 15. We fed 30 ol $35 \mathrm{lbs}$. per cow out of it until July 10, 1909. The year previous the cows fed on dry feed anil grain only produced as follows: Thirteen cows averaged $242.89 \mathrm{lb}$, fat per cow and re. The next year, $1908-09$, the same cows, 
with one exception and fed almost the same way, only with less hay, but in addition a feed of silage twice a day gave us \$347.59 lbs. fat average per cow and a creamery check of $\$ 1,048.00$. This shows an increase lrel cow of $105 \mathrm{lbs}$. of butter fat. We will say that 75 lbs. of this increase was due to the feeding of silage. Seventy-five pounds of buttel fat at $28 \mathrm{c}$, our average price, amounts to $\$ 21.00$. This is a conservative estimate of its value to us for one year. A herd of 25 cows would return $\$ 5: 5.00$ at that rate, more than enough to pay for the silo in one year. Could anyone ask lor a better investment? There was a similar increase in the milk yield. The herd gave an average per cow of 5,462 lbs. of milk in the year from October, 1907, to October, 1908. The next year, with corn silage as a part of the ration, they returned an average of 7,953.15 1bs. milk pel' cow, an increase of $2,499.15$ lbs. milk. Allowing that 75 per cent. of the increase was due to silage we have 1,868 lbs. milk at $\$ 1.30$ per hundred gets us $\$ 24.2 x$. Doesn't that sound good to the man who milks cows? These tignres are not mele aplroximations, but are taken from our records kept of each cow. So, Mr. Dairyman, if you want to make money, put up a silo and do it quick. You will find that if you do you will have the best and cheapest milk and butter producing feed on earth.

Don't allow the expense to keep you from getting a silo. It is sure to come back to you with big interest. There is nothing that will help a dairyman or stock feeder towald better conditions more than a silo used in the right way.

IIARRY B. IRISH,

Farina, Illinois.

\section{CORN CAUGHT BY FROST.}

Indiaxa Siro Co., Anderson, Ind.

Gentlemen:-The sllo 1 received of you last August 14th is 0 . K. and 1 am pleased with it. I changed work with my neighbors and erected it with very little expense outside my own labor. By committing to memory your instructions I had no trouble in raising the silo, the work moverl right along. Did my own painting and put on the roof, etc.

Dug $7 \frac{1}{2}$ feet in ground with 24 -foot staves, equals a $10 \times 311 / 2$ - foot silo, and built a cement wall, but from the experience I had in taking out the ensilage down even with the top of wall convinced me that I would not want a cenent silo. The ensilage was frozen $1 \frac{1}{2}$ feet from the cement wall toward the center of silo and I conld not dig it loose with a fork; but all the way up the staves during the freezing weather the ensllage was not frozen more than two inches and came loose easily with a fork, being right to the opposite of my old ideas.

Our corn through this section was killed by an early frost two weeks belore I could fill, cutting down the value of corn and losing lots of the leaves. But my cows, calves and horse would leave good timothy or clover hay for the ensilage.

My stock is all in a good healthy condition. My cows came fresh in mid-winter and have been giving a good flow of milk. My neighbors give me compliments on how well my cows look. I am positive the silo has saved me three tons of hay, which at present prices means $\$ 40.00$ or more. I milked one heifer until about six weeks before I sold her and the butcher said she was a good beef.

I am satisfied with my frosted corn experience and if nothing happens, I have my silo ready to chuck in the corn as quick as it is frosted after this for better ensilage and better yet when the corn don't frost, getting all there is in it.

With success to your business, I remain yours truly,

WM. J. HARRISON, Cedar Springs, Mlch. 
Indiana Silo Co., Anderson, Ind.

Dear Sirs:-You will please find enclosed photo of my barn and two Indiana Silos.

Before we got the silos we were only able to keep 14 head of cattle and 3 horses. Now on the same land we are able to keep 45 head of cattle and 5 horses.

The increase is due to the silos alone. Yours truly,

G. W. HIRTZELL,

Effingham, Il:.

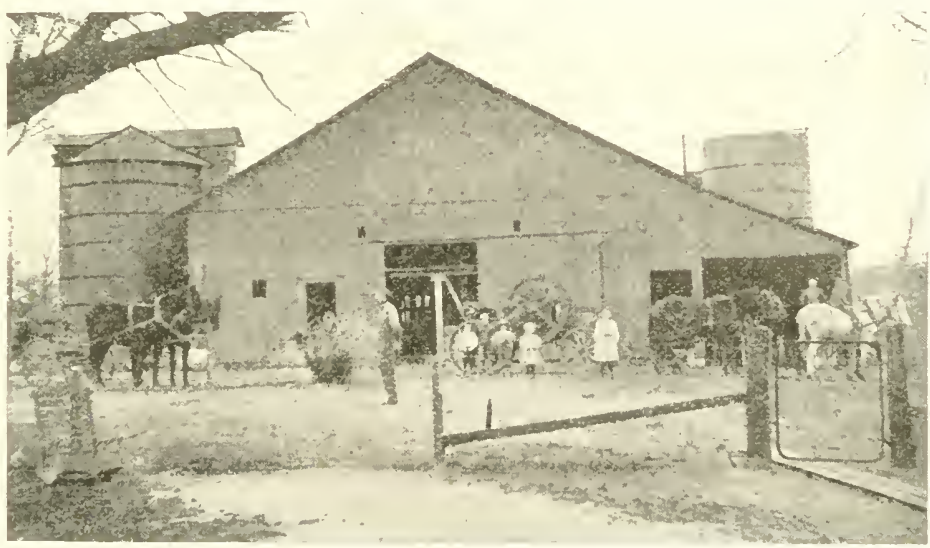

George Hirtzell and His Barn and Silos.

\section{SAVES CORN AND HAY.}

Indixa Silo Co., Axiersox, Ind.

Gentlemen:- In 1908 I bought from H. C. Hargrove, of Des Moines, one of your $16 \times 30$ Indiana Silos. The silo is highly satisfactory, keeping. my silage perfectly, anil the results obtained by feeding silage are beyond my expectations.

Before I had a silo I used to feed 20 head of steers 15 bushels of ear corn per day besides all the hay they would eat. I now feed the 20 head 6 bushels of ear corn and 800 lbs. of silage daily and they eat about onethird of the hay formerly fed. I make a net saving of 9 bushels of corn per day and my steers put on flesh nuch faster ou silage feed than on dry feed.

I save the use of two-thirds of my meadow and on this ground I grow corn enough to fill my silo. Nine bushels of corn a day for 90 days, the length of time I feed, makes 810 bushels. Corn is worth now 60c per bushel, making me a net saving of $\$ 486.00$ on feeding one car load of steers 90 days. Yom's very truly,

NELS S. HILLAND, Huxley, Iowa 


\section{SEVEN YEARS A USER.}

Indaxi Silo Co., Anderson, Ind.

Gentlemen:-On December 1, 1900, we made cur first trip to Newark, Onio, in the retail milk busıness. In the lall of 1902 we erected our first silo, being eight-sided and lired on the inside with one-inch yellow pine.

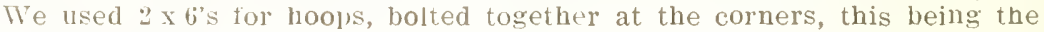
first silo erected in this neighborhood.

We used this silo for two year's, but the second year so much of the silage spoiled that we concluded to erect one that would keep the silage bettel. We fillally decided on the Indiana Silo and have had no reason for regretting it since.

J1) the last seven years there have been a large number of silos ercoted in Licking county. I think we would be sale in saying that where there are six lndiana silos there is only one of any other make.

I don't see how some dairymen can keep on in the same old rut by fercing dry teed when prices are so high for all feeds, when they can get such a large amount of succulent and palatable feed in a small space without uractically any loss. Many dairymen have an idea that the cost. of filling a silo is so much greater than harvesting in the old way. According to my observations it is practically the same if you take into con. sideration the waste in leetling, handling and exposure to the weather. The following lepresents the cost of filling our silo in 1909, putting in 130 shocks of 144 hills each. Our silo is $12 \times 33$; twentr-four-foot staves and nine teet in the ground. After it had settled we had 28 feet of silage or aboit 7 is tons rosting 70 cents per ton for filling:

Power and cutter .............................\$18.00

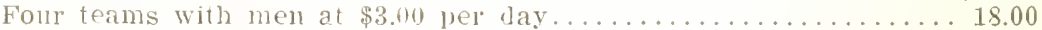

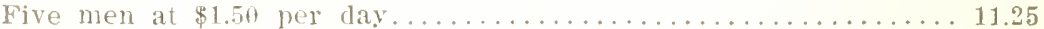

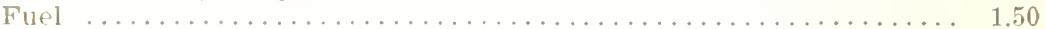

Total

For harvesting the same amonnt of corn the usual way:

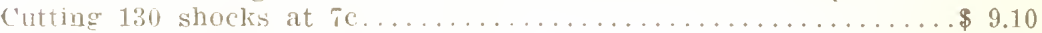

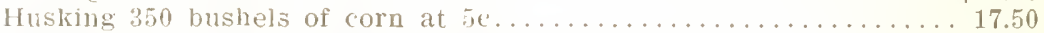

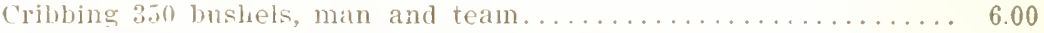

Stacking stover, 130 shocks, 2 mon and team . . . . . . . . . 6.75

'Total

$\$ 39.35$

A diflerence of $\$ 9.40$ in lavor of the old way, but I think the waste in feeding ald halling will be equal to that or even more.

Admitting that it costs no more to mut a crop of corn into the silo than it does to harrest it the old way, does it lessen the cost of producing milk or beet? For answer I will refer you to any dairyman that has ever used a silo.

I'hen we first put wh our Indiana Silo we erected it on a rented farm with the understanding that if the farm were sold or we moved away we conld remove the silo. In the tall of $190 \mathrm{~s}$ the farm was sold, but we did not have to give possession until the first of April, 1909. ln the fore part of the winter we fed lather heavily on our silage so we could get it fed out by the 1st ol April. By the second week of March we began to cut down our silase ration and feed more dry feed, the reason being to get our lerk on a full lation of dry feed with as little shrinkage in the milk flow as possible. The last week in March we had our herd on a dry ration wilh the following results, as compared with silage ration in the first week in March: 


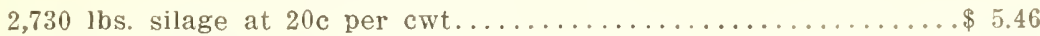

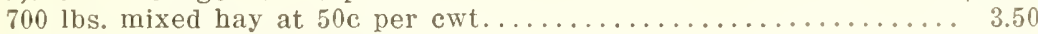

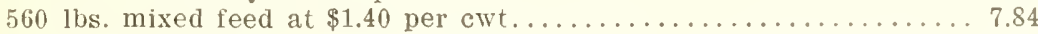

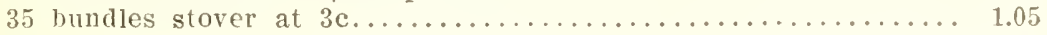

Total

$\$ 17.85$

Total amount of milk produced, 1,743 lbs.

\section{Dry Ration for Seven Days.}

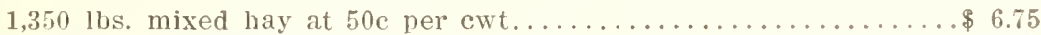

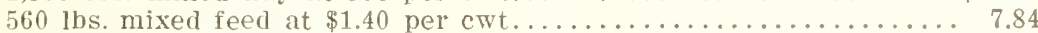

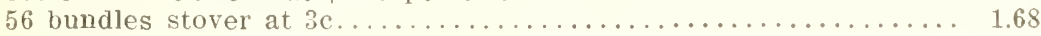

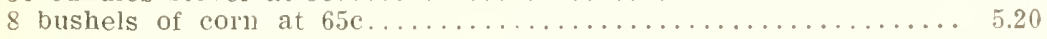

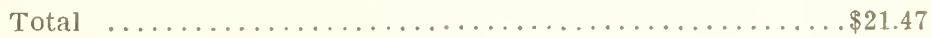

Total amount of milk produced, $1,572 \mathrm{lbs}$.

This leaves a difference of $\$ 3.62$ in favor of the silage ration in cost of feed consumed. Also a difference of $171 \mathrm{lbs}$. milk or 20 gallons, at $16 \mathrm{c}$ per gallon, making $\$ 3.20$ in favor of the silage ration, a grand total of $\$ 6.82$ (almost $\$ 1$ a day difference) in favor of the silage ration. One dollar's worth of leed of the silage ration produces almost 100 lbs of milk. One dollar's worth of the feed of dry ration produces almost $751 \mathrm{bs}$. of milk.

Of course, the first cost of a silo seems to be too large an undertaking lor a gcod many dairymen. Considering the life of a silo it amounts to very little each year and the repairs amount to almost nothing outside of painting. Our Indiana Silo has been in use for five years, has been torn down and moved once and is as good as new and will last for many years to come. A farmer will pay from $\$ 100$ to $\$ 125$ for a self-binder to be used from two to six days in a year. Some dairymen will not invest from $\$ 100$ to $\$ 200$ in a silo to be used from six to eight months in the year. Why is it? Because they cannot see where the silo makes them dollars and cents.

WILLIAM L. KELIEY,

Newark, Ohio, R. F. D. No. 2.

\section{SELLS HAY NOW.}

Indina Silo Co., AnDerson, Ind.

Gentlemen:- I should like to have sent you a picture of my silo, but have no photographer near. I think very highly of silage for feed for all kinds of stock. I buit one $10 \times 30$ teet in 1908 and one $14 \times 30$ feet in 1909 , side by side, and built one roof across both and like it fine, as I can fill both without changing cutter.

I sold enough extra hay to pay half the cost of my silns the last two years, besides having my stock in better condition. I lave been told not to feed silage to heavy cows and brood mares, but mine get their regular feed of silage and the young stock are lively and able to jump when I find them-from lambs to colts.

My silos are covered with standing seams galvanized iron. I think every stock farm should own one large and one small silo, and I think any one will be sale in buying the Indiana Silo. I like the doors very much. Respectiully,

R. A. GOULD, Bone Gap, Ill. 


\section{BROWN SWISS STOCK FARM.}

IndAANA Silo Co., Anderison, Ind.

Gentlemen:-I have been using ensilage for nine or ten years. I did not fully appreciate a silo until I had to get along without it, after using one lor eight years.

I know that ensilage is the cheapest feed we have on the farm. I feel when we have the silo filled that I have so many acres of corn, cut, shredded, nusked, shelled and ground and put up in the best possible shape to leed. It is always ready, don't have to go out in the cold and snow to get it. I feed ensilage the whole year. A small silo for the summer teeding is a good thing to live. I have used a concrete silo and have used a wood silo of $1 / 2$-inch stuff, doubled and plastered on the in. side. I have now two Indiana Silos on the north side of barn, with a

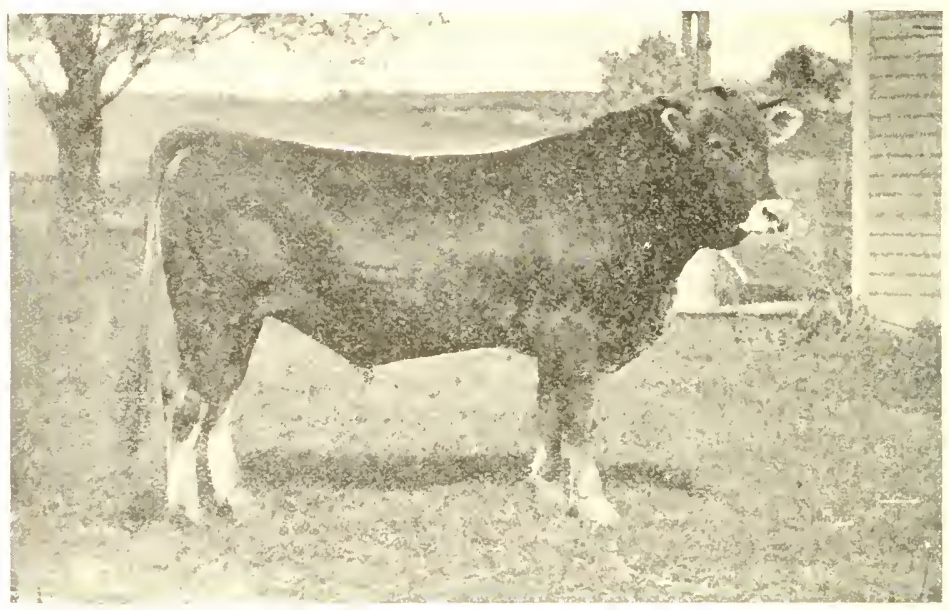

Ira Inman's Brown Swiss Bull.

squale bullding of rlop siding around it with a llat rool. l used yellow pine for silos: it was No. 1 tank stock. Ensilage did not ireeze in them this ing cold winter.

1 believe the Indiana silo is one of the best silos made. Yours very truly,

IRA INMAN,

Beloit, Wisconsin.

\section{BEST SILO IN COMMUNITY.}

Indixi Silo Co., Axterson, IND.

Gentlemen:- In relly to yours of March 24, 1910, in regard to the silo purchased of you would say that it has been a great benefit to me. My dairy cows nevil did so well as they have this suring and never looked so well. The silo has been a sreat saving to me in hay. The man who filled the silo last fall and who had filled ten othel silos said this was the best silo he had seen anywhere.

I would not vart with it for a large amount of money and I will gladly recommend yoir silo to others who contemplate buylng one.

GEORGE PRESAN,

Tenant for M. Grebler, Philadelphia, N. Y. 


\section{WHAT A 14.YEAR-OLD BOY KNOWS ABOUT SILOS.}

\section{Indiana Silo Co., Anderson, Ind.}

Dear Sirs:-I thought I would write you the composition that I wrote and read at the Baders High School Nov, 5, 1909. I wrote it myself. I am 14 years of age. We had a corn exhibit and my question was to write about silos. I want this published in your silo papers. This is what I wrote:

A silo is an air-tight pit for packing away green fodder and green clover hay. I will write a few things concerning silos, and I will do so by telling what 1 have learned about them during the past year.

In August, 1908, we built three Indiana Silos at our barn. These silos are built of Long Leaf Yellow Pine. Some are made of Cypress and Oregon Fir. This pine grows on the lowland along the lower Mississippi not far from the Gulf of Mexico. The Oregon Fir grows in Oregon. This timber is known to be a very durable kind of wood. It is sawed two inches thick, six inches in wiath and is dressed on both sides and tongued and grooved, so that the staves fit together perfectly ail tight and water tight trom top to bottom. The staves are all 24 feet long and are held together by strong hoops made of steel. They are built perfectly round and perpendicular.

One of our silos is 12 leet in diameter and 24 feet tall and holds 55 tons of feed. Our other two silos are 14 feet in diameter and hold enough ensilage to leed 20 head of grown cattle six months off of 8 acres of glound. The small silo holds enough ensilage to feed 16 head of grown cattle six months off of 5 acres of ground.

llow does this compare with the old way of feeding cattle? This is how it compares: You take 25 head of cattle and feed them in the old way, it will take about two or three acres of cut corn lodder to leed a cow through the wiuter and in the spring your cattle are poor and look bad. Now you can take the same amount of cattle and feed them in the new way and you will find that you can winter them on less than one half of the ground, without half the work shucking the corn fodder and you have not got the corn stalks to contend with in the spring. And if you teed ensilage you will have an easy time hauling the manure.

These silos are the very latest way of taking care of your corn and hay crops. The feed in these silos heats very much. The feed is cooked and it is warm all the time. When you handle it the stean will fog up rom the feed. The cattle relish the silage and they eat it all up and they will not eat up all of corn fodder. All kinds of stock will eat ensilage if they can get it.

These silos are built on a round concrete foundation. When you go to erect a silo you put up the scaffold first and then the door frame and next the staves. The staves are loeld in their places by lath which are nailed inside of a barrel. The door frame has eight doors in it. The doors have handles so as to make a continuous ladder. There are several different silo companies. The Indiana Silo Co., and Saginaw Co, and Ross Co. I think the Indiana Silo Co. is the best company to deal with. They sell what they advertise. I think every farmer who has stock ought to have a silo. It will save him money and labor and the exposure of shucking corn fodder in the winter time.

There is an acid in this feed which preserves the wood and eats up a piece of ilon. The leed in a silo is sour and yet it is green and it keeps as long as the silo lasts. This feed will mold about 6 or 8 inches on top, but will not be molded any farther than the air will go unless you have not tramped it good. Yours truly,

FRED GUNTER,

Baders, Ill., R. F. D. No 1. 
INDIANA SHLO Co., ANNERSON, IND.

Dear Sirs:-Answering to inquiry as to what I think of the Indiana Silo, will say the use of a silo has been very profitable to me. In September, 1903 , I erected my first silo, the use of which was so satisfactory that in September, 1906 , having bought another farm, I erected another silo on it. In the fall of 1905 I conducted an experiment on feeding steels on my farm, having on hand some yearling steers and some twoyearolds. Began feeding them November 25th. 'The two-year-olds at that time averaged $972 \frac{1}{2}$ pounds; the one-year-olds 566 pounds each. Their leed was silage made from well-eared corn, except about 30 days at latter end of teeding an allowance of two pounds daily of ground corn was added. Every day they were turned ont of the stable into the feed lot, where they had access to water, a little dry corn fodder and a straw stack. Fed the two-year-olds 109 days and then sold them. Their arerage weigint was then 1.325 pounds, making an average gain per steer of $3521 / 2$ pounds. The one-year-olds were fed 110 days and then sold to butcher. They areraged stl pounds, making an average gain of 275 pounds. Having a stock seale in my barn, l weighed the steers at legular intervals and could not notice that they waincel any taster alter the sromel corn was adiled.

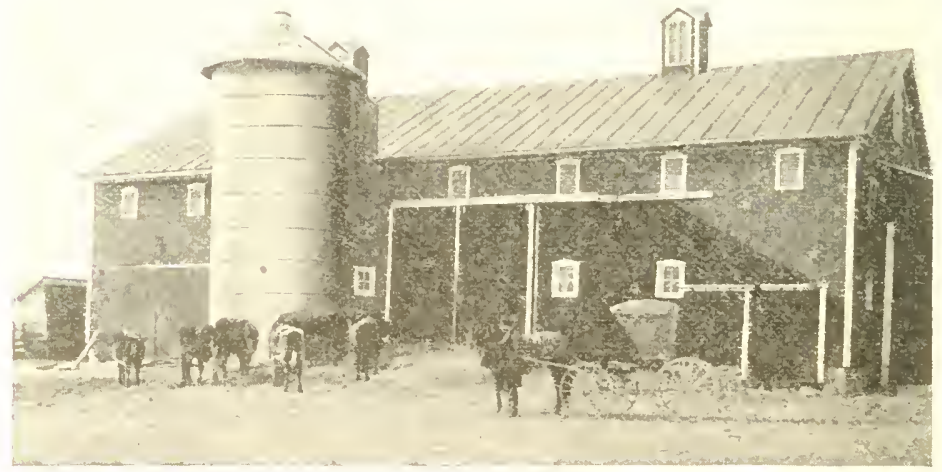

Barn and Silo of Levi Hile, Showing Some of His Cattle.

since making the above wijeriment on feeding steers I have fed some steers evely winter, and I believe silage by lar to lie the best and eheapest teed to mrepare them for market, or even to feed rom calves up.

1 also am keeping a small dairy and find silage to be the best feed to keep rows in gook order and in increasing the flow of milk and by adding a small amount of wheat bran to the silawe it is fully efual to the best of pasture for cows. All ill all, a silo will pay its cost every year. This provel to ny own satisfaction in my six years' experience with silos, and a good one such as manulactured by the Indiana silo Company will last a life time.

l have used silage lor feeding all kinds of stock on the farm and find it the best ever. Breerling ewes will lo well and raise fine large lambs, and for teeding for market sheep or lambs silage is the best feed to insure weight. The hood male fraves it and does better with it. The sow and winter shoats are liuch improved by its use. 
An acle of coln through the silo teeds twice as far and can be harvested earlier than the old way. Silos ale coming into use very fast. When $I$ got my first one there were no others in this vicinity, but every year since there have been more silos erected, and the Indiana Silo is very prominently taking the lead in this vicinity. To my knowledge 22 Indiana Silos were bought and only 2 of other makes last year.

Will conclude by saying that my dealings with the Indiana Silo Company have been most pleasant and satisfactory, and their word can be relied upon in every respect. Yours truly,

\section{LEVI HILE, Carey, Ohio.}

\section{SOME ADVANTAGES OF THE SILO.}

Indiana Silo Co., ANuersor, Ind.

(1) It doubles the value of the products put into it.

(2) It leaves the land in ideal condition for fall wheat and alfalfa, and in Kansas the corn can be cut and put into the silo in time to sow either, and such land, when the corn is taken off, makes an idleal seed bed.

(3) It enables a farmer to fall plow his land (which is much better cnan spring plowing) and exposes the soil and its attendant evils to the action of the frost and spow of the winter.

(4) Experiments conducted at the Kansas Agricultural college during 1.908 showed that plowing the land during late fall or early winter destroyed practically 100 per cent. of the over-wintering pupae of that destructive enemy the corn ear worm.

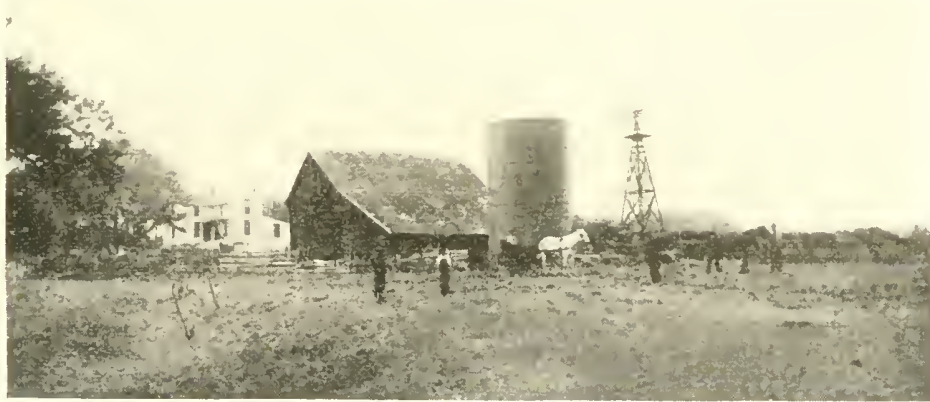

M. O. Keeffe's Farm, Topeka, Kans.

(5) It is a quick and wasteless way of harvesting a corn crop and the men cannot slight the work as every hand must do his share in order to keep the cutter going, and, compared to the old way of chopping corn fodder out of the ice and snow, it is a very easy way of finding it ont as a person does not have to be out in the cold.

(6) Any invention that saves labor and increases the value of our crops will entance the value of our land, and the silo will do all this, as it enables a farmer to save all his corn crop or whatever he puts into it.

These are some of my reasons, as they now appear to me, for advocating the use of a silo and I submit them to your judgment to publish them if you see fit. Respectfully yours.

M. O. KEEFFE.

Topeka, Kan. 


\section{IT PAYS FOR ITSELF IN 120 DAYS.}

Indina Silo Co., Anderson, Ind.

Gentlemen:-I wish to tell you, if I can, what I think of a silo.

I think more of an Indiana Silo than of any other make that I know anything about.

The silo saves labor, lessens the exposure of winter feeding, builds i1] the fertility of the soil, adds to the good appearance of the farm and puts mole dollar's in the bank to the owner's credit. Following I wish to give you a few striking figures and proofs of the above statement.

It costs us at the least ealculation, $\$ 6.50$ per acre to harvest corn and stover of a 70 -bushel yield, while we ean run the same into the silo for $\$ 5.00$ pel aele. Thus on 12 acres we save $\$ 18.00$ in barvesting.

In a leeding test we found it took as mueh ear coln to full leed 20 steers without silage as it did to full feed 30 steers with silage, thus saving 3 bushels of corn per day, or 540 bushels in the 180 days, worth $\$ 297.00$. We also found by same test that on the 30 cattle we saved about 25 tous of hay or $\$ 200.00$. We find that, due to the better finish of the silage eattle, they were worth $25 \mathrm{e}$ ler cwt. more, thus making us $\$ 2.75$ per head or $\$ 72.50$ on the 30 steers. Therefore the silo returned $\$ 297.00$ 1)]us $\$ 200.00$ plus $\$ 72.50$ plus $\$ 18.00$, which equals $\$ .180 .50$. The silage was worth $\$ 300.00$ (high estimate), miking a net profit in lavor of silage of $\$ 250.50$. The silo cost about $\$ 275.00$. Thus you see the silo returned more than 100 per cent on the investment.

Can we buy any other tool that will make any way near the above returns? And I did not include in those figures the saving in labor in feeding or the added value to the farm due to the better improvement.

If you can use this letter to help convince a brother farmer that he needs a silo, then we will be pleased for we know by so doing we will have bettered his condition. Truly the friend of a silo,

WM. M. JONES,

Fairmount, Ind.

\section{NEVER HAD STOCK DO SO WELL.}

Indiana Silo Co., Anderson, Ind.

Gentlemen:- Four years ago this coming year I bought a 24 -foot silo of you. I never for a minute regretted the money spent for it. I feed silage to cattle, hogs and poultry. I never had stock do so well, especially in winter time, as it does on silage. I find that six aeres of corn eut into silage will gro as lar as 20 acres of corn in dry fodder and be much better. 1 am feeding my lrood sows nothing but silage and they are doing fine.

Last June wt had a very severe wind storm in this locality, which blew down trees, windmills and silos. Well, mine wasn't anchored, and of course it went down flat on the ground. Twisted the hoops in all shapes. I looked at the wreck and concluded my silo was a goner. I pxpected to find the staves underneath all splintered and broken. Myself and two sons, 17 and 19 years old, got the hoops in nice shape and the staves piled up. Later on we put the silo on the same foundation, filled it with eorn, which is keeping fine. Any one not knowing that the silo had bcen blown down eould not detect any damage done to it at all.

I am so well pleased with the way the silo behaved through the storm that if in the future I slould put up another silo it certainly will be an Indiana silo. Yours truly,

PETER GROSS,

Goshen, Ind. 


\section{ENSILAGE FED TO POULTRY AND PIGS.}

Indina Silo Co., Anderson, Ind.

Gentlemen-ln reply to your letter dated March 24, will state I am well pleased with my silo. No dairyman can afford to be without one. I began feeding ensilage about December 1st, 1909. I fed 9 liead of cows, 2 yearlings and 4 colts. I fed to each cow $12 \mathrm{lbs}$, of ensilage twice a day. To the colts and yearlings I did not feed quite so much as I did the cows. $I$ also fed with this ensilage 5 toms of mixed hay and 100 shocks of corn fodder. I will state that I will have enough silage to feed my stock until the last of Aplil. I have never had my stock to winter as well as they have done this winter. I fed my poultry and pigs ensilage. My silo is $12 \times 20$.

Wishing you much success with your Indiana Silo, I remain yours truly, JAIIES M. GREGORY,

Bluford, Ill.

P. S.-I will send you the picture of my silo and cow barn later.

\section{GAIN OF $\$ 1,608$ ON THIRTY-THREE CATTLE.}

IndixA Silo Co., Anderson, Ind.

Gentlemen:-I purchased a silo from your agent, which I filled with corn about the middle of October and began feeding on it the 25 th of November. Fed 33 head of Polled Angus and Hereford steers, 20 head of 3 and 4-year-olds and 13 head of 2-year-olds. We fed 140 days, but cannot give correct figures or those cattle on account that I bought them by guess weight, but was guessed at 1,050 , that is, the 20 head of 3 and 4 -year-olds. They were shipped and on the market and were in fine shape. Their hair was the finest that I saw on the market when they were shipped. They averaged 1,292 and sold ior $\$ 7.65$ pel hundred weight. The 2-year-olds brought $\$ 7.25$ jer hundred weight and weighed 930 , which I consider good. They were all fed on ensilage, some coln and pea hay. I will say that the cost on 20 head of steers, when put on feed, was about $\$ 46.00$ per head, and the $13, \$ 26.00$ per head.

I consider youl silo one of the finest and cheapest that a farmer ever put on his farm. Yours very truly,

JNO. Z. GENT, Carbondale, III.

\section{A GREAT ADVANTAGE.}

Indiana Silo Co., Axderson, IND.

Dear Sirs:- These few lines will come to you a little late. I must beg you to excuse me that my letter nust be written in German as I am not able to write English.

You wish to know what I think of your silo. I have two of your 150 tons each. I cannot express the advantage that I have by the use of the silo nor can I see how I could do withont them. As a farmer I could do without a binder as easily as I could do without the silo. A stock raiser or dairyman should not be without a silo to supply the feed. The cattle are healthiel and the milk good, with no after taste and is good in color. With the use of the silos I can feed four times the amount of cattle with less troubte.

The Indiana silo has my preference over any other make and it is possible that in the near future I will add a third silo.

F. IV. GOOS,

Hamilton, O., R. F. D. No. 9. 


\section{FINDS COMFORT IN HAVING FEED HOUSED IN SILO.}

Ixmixa Silo Co., AxDerson, Inu.

Gentlemen:- Yours of the 18 th at hand. I will say for your silo that it is the best silo on the market. I have seen a good many different kinds, but none that fill so nicely nor the doors go in without breaking them. I would not do without one of your silos for three times the cost.

I can feed more stock on 6 acres of land than a man can on 25 acres any other way. With a silo you have your feed in the barn and ont of the snow. How nice it is to sit in the house in the rocker and see my neighhor out in the field with a shovel and an ax digging in two or three feet of snow and the sweat ruming down his face and puffing like a steam engine. 'There is where the Indiana Silo comes in for comfort, and the next thing the manure is in fine shape to go back on the land. There are no stalks or rubbish to contend with and my cows, chickens and colts come out in the sluring like they had been stall fed, when my neighbors', l can stand 80 rods off and connt the ribs in the cows and see them hump up as if they were starved. Mine ar full and plump. I use very little hay, scarcely any. Will not exceed 200 lbs. hay a month.

I would not do without a silo if I only harl three cows and fifty chickens. Yours,

O. F. PETERSON, Zion City, Jll.

\section{FINDS SILAGE CHEAPEST AND BEST.}

Ixmaxa Sulo Co., Axmersox, Ixu.

Gentlemen:- I have user a silu three seasons now and it has given me very satislatery lesults.

The cost stoms at first o be rathor high, but considering the cost and amount of barn room it takes to store hay in and the difference in the cuality of the feed, it makes

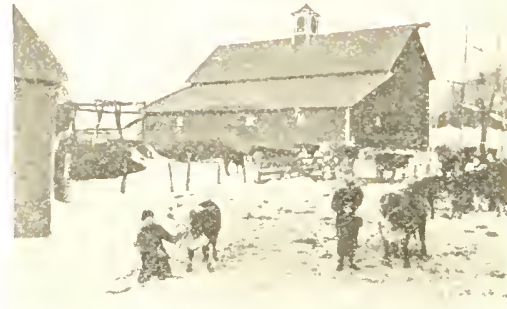

Julius Johnson's Herefords, Story City, Ia. the first cost of a silo reasonable.

I have a silo that holds 75 tons of silage. This cost me when completel $\$ 200.00$. I have filled this silo with live atres of corn yielding 60 bushels of corn to the acre and the expense of filling was $60 \mathrm{c}$ ley tom, making the total cost of filling \$45.00. I can leed 18 milk cows, \& calves and 25 head of sheep, busides some hogs and ponltry, which keeps them in very good condition for six months, saving at least 25 tons of hay on this amount of stock at the rate of $\$ 8.00$ per ton, making, a total of $\$ 200.00$, which was the cost of silo when milt, besides my stork being in botter condition when fed on silage than when ruming on wond pasture, besides rows giving a better flow of milk and the quality richel.

Figmring the cost of lutting up this hay and the picking. storing and grinding of this amount of srain stoled in the silo, the cost of filling the silo will be considerably below. Besides silage is better and easier digrasted. Also talie into musideration that silage ran be put into the silo in almost any kind of weather, which makes it a very murh safer rrol) than hay and, besicles, lesis acroage is requiled for the same amount of fred. Also consider that the stover which is lett in the fields, is 
almost worthless. It is only a matter of expense of getting this stover into the silo, which is but very little more than taking care of it in the shape of corn fodder, and it has a world of difference in feeding value, and there is but very little waste, makes better manure, and is easier handled, always ready, and out of the snow and rain.

It stands to reasou that the more silos there are in a neighborhood the more and better the help will be and the less expense. And the less expense the more profits. The cost of silage depends on the quality of corn, the experience of your help and, also, your machinery, whether everything is running to its full capacity or not. It pays to buy the best machinery and arrange wagoms and other necessaries as handy as possible. Respectfully,

JULILS N. JOHNSON, Story City, Towa.

\section{SILO KEY TO SITUATION.}

Ixdiax Silo Co., Axderson, Ind.

Dear Sirs:- In the summer of 1896 I had been running a dairy two years and had gathered a herd of some 23 or 24 head of cows. My hay crop liar failed and I was up against the same old proposition of what could I winter my cows on profitably. I had a good corn crop, but I never could get any results from feeding shredded fodder or fodder on the stalk. Previous years I had 20 or 30 tons of clover hay and with ground corn and bran I made a fairly good ration and was able to play even.

I had a couple of hundred dollars and was undecided whether to put my money into hay or buy a silo. I had to do one or the other or have a sale, so I decided to try a silo. So I sent an order to the Indiana Silo Co., and after I got my silo erected and roofed my two hundred was all gone. I joined with twc neighbors and we bought an ensilage cutter. My part cost \$55.00. It began to look like all going out and nothing coming in, for I still had no feed. Not counting anything for my own teams it cost me another $\$ 25.00$ to fill my silo with ten acres of good corn. I now had something near 100 tons of feed standing me at somewhere between $\$ 2.50$ and $\$ 3.00$ a ton.

I began feeding ensilage the 8th day of October and at first it seemed that the silo would soon be empty, but as time went on the feed did not go so tast and it was the first of June before I saw the bottom of my silo. In the eight months that I fed ensilage my cows averaged $\$ 200.00$ a nonth, which amounted to $\$ 1,600.00$.

Cost of silo, cutter and filling...............\$280.00

Expended for cotton seed and bran................. 150.00

Original value of corn. ................... 300.00

Total expense.......................\$730.00

The difference between the net receipts and the expense left me a net profit of $\$ 870.00$.

I purchased a second silo last year. It had been used one year and I am going to feed ensilage this summer, as I am short on pasture.

The ground that I am farming would sell in the market for $\$ 1$ in 0.00 an acre and there is only one way that $I$ can see to farm it profitably, and that is by the use of silos.

I expect in the next three years to keep a cow for every acre of ground, and the key to farming high-priced land is the silo.

ROBERT JAMES,

Mgr. Cedar Grove Dairy, Shelbyville, Ind 


\section{HAY SOLD PAYS FOR SILO IN ONE YEAR.}

\section{Tritiva SH,o Co., ANDERson, Ind.}

1 purchased an Indiana silo and don't see how a man feeding stock (an afford to be without one. The ensilage makes the very hest of feed, it loing equal to bran for producing milk and is much cheaper.

I feed nothing but lay for roughmess and last rear I used n] all my hay and bought five tons hesides. This rear, with a silo, the same amount of hay, and the same amount of cattle, I sold $\$ 200.00$ worth of hay and saved $\$ 50.00$ on the mill feed. (Have 20 milch cows.)

It seems to be a very healthy feed. Last year I had trouble with the cattl getting off their feed, and this year I have had no trouble at all. l have also tried it with young calves, hogs and chickens, and find it to De montralled.

I think erery man that has stock and has no silo. pars for one every rear and doesult get it.

\section{J. IV. HAMILTON,}

Avena, 111.

\section{AN ALL ROUND FEED.}

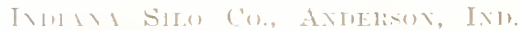

Gentlemen:- The experince I had with the silo has been highly motitable and satistactory and l recommend them to every one in the dairy husiness or srowing live stock on the larm. I have found that there is mole eromomy in ferding silage than any other feed stuff. It kreps all ol my live stock in better growing condition than dry feed alone. silage, how sur, is more completely consumed, more readily eaten than when the samt material is cmed, for it helps wonderfully in carrying a herd though the winter or a dry time in summer and at the same time makes your fows give more milk than they ever did before. It seems as if there is no loss whatever in feeding value, for stock certainly eat silage up cleaner and with better relish alter it has been mit in the silo a month than when it is fed directly from the field, for corn loses considerably if not jut in the silo. There are no aggratating coln stalks when silage is fed allit silage comes nearer being an a'l-lomnd feed than most any other teed. No one can get the most protit out of his cows without building a silo, and many have greatly increased their business by having them, for ensilage is the greatest money makey in the dairy. The silo prevents the waste of corn stalks, which contain about ourethird of the corn crop, and silage is more conveniently handed than dry fodder.

Corn is the best crop to get the most feed oft an acre for on an average it will produre about 10 tons to the acre. I have found that it takss loss than three-lourths of an acre to feed one row the whole year romml, romting 10 tons to the arre and feeding each cow 40 pounds a day. 'The fact in keeping a cow on the product of less than an acre is a matter to be considered ly every one who has an interest in live stock.

rine cost to till my silo amounts to about $\$ 1.30$ a ton. Bran at $\$ 24.00$ a ton is a fretty expensive lesed, top I have bought more than \$27.000 worth of bran a year; but since I had the silo I reduced it to about half the anlomint, and I think that my silo nearly flail for itself in one year.

In tact, a smalt per cent of the farmers liave vet built silos. Seems lik most falmels dom't realize their value and usefulness mpon their farms.

The wooden stave silo costs less in construction and keeps the silage in a frerfect condition. Every farmer who has a silo in this neighborhood is lelighted with the results he obtains and all wish the Indiana Silo (ompany a success. Yours truly, 


\section{A PLEASURE AND PROFIT.}

IxllaxA Sllo Co., AxDERsox, Ixin.

Gentlemen:-I have had the experience and pleasure as well as profit

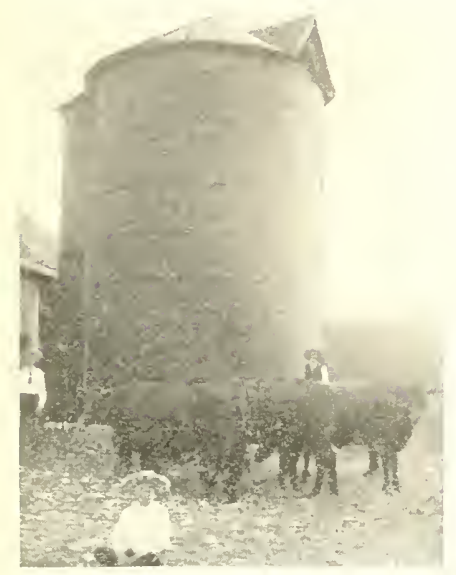

Some Good Specimens on Samuel Fisse's farm, Versailles, Ind of using one of your Indiana silos. I bought a hundred-ton silo of your agent, Sam E. Ellerman, who recommented them as labor saving, feed saving, and by feeding silage producing a better class of fat cattle for malket, as well as heing a milk-ploducing tocil for cows.

This is the second winter I am using your silo and am murh lleased with the results it is noducing. A year ago this winter I fed seren head of steers for malket, besides feeding my 8 milch cows. I weighed the 7 steers the 14 th of November, 1908, belore I started to feed them. Thty weighed 7,600 lbs. Feb. 6th, 1909, I voighed them again. They weighed $8.7001 \mathrm{lss}$. May $1 \mathrm{fth}, 1909$, at the lime of marketing, they weighed 9,520 lbs., gaining $1.9201 \mathrm{ls}$. in about if months, an average of $27+1 \mathrm{hs}$. per head. I engagen them at $6 \mathrm{c}$ per 11 . As I delivered them at Friendship they weighed 9,400 lbs. One of the largest ones weighed 1,620 lbs. at home. I received $\$ 564.00$ for the bunch. The stock buyer who got them said they were the slickest bunch of cattle that entered the stock yards at Cincinnati.

As for milch cows, silo feed cannot be excelled. The butter made from cows fed on it is a nice color. The yield of milk pel coir increases as socn as silage is fed. If coln is put into the silo in the right condition it maintains its sweetness of stalk and ear. When silage is fed nothing else need be fed but a little rough feed such as clover hay.

So I adrise any extensive falmer to get one as soon as possible if he is any way concerned or takes an interest in farming. Be up-to-date tarmers and save time and feed. Yours truly,

SAMITEL, FISSE.

Versailles, Ind., R F. D. No. 1.

\section{A COMPARISON.}

Indixt Silo Co, Avderson, Ind.

Gentlemen:- Yours of the 21 st inst. at hand and in reply to same will say that we are well satisfied with the silo we purchased of you two years ago and contemplate getting another the coming season.

A man in our community hought a different silo yast season just becallse ne got it a conple of dollars cheaper. When he got his silo he was sorry he didn't take our advice and buy an Indiana Silo.

We cannot give you in exact figmes what the silo has done for us financially, but will compare our cows, which are only common cows, with those of an old dairyman who is feeding dry feed. We are milking 15 cows, which give $340 \mathrm{lbs}$ of milk per day, and the older man is milking 29 cows and only receives $370 \mathrm{lbs}$. of milk. He takes good care of his cows and feeds a heavy grain ration. The silage doesn't only produce milk, but it keeps the cows in good health. Theil hair lays smooth and 
has a glossy appearance that one cannot get from dry feel this time of the year, It is also an ideal feed for young stock. They as well as the cows prefer the silage to grain. The most important thing is that one gets twice the feed from one acre at less cost than shredding corn.

One thing one must be cautious of and that is not to put it up too green. Let the corn get well glazed. This doesn't only give more leeding value, but it makes a more palatable food.

This cry of tainted milk is mostly prejudice. If one is clean in the barn and takes care of his milk there is no danger whatever.

IVishing you tuture success, we are yours,

KUMMROIV BROS.,

Molrison, Ill., R. F. D. No. 7.

\section{BEFORE AND AFTER.}

Irimaxa Silo Co., Axnersox, IND.

Dear sirs:- l purchased one of you silos last fall, and have used it this winter to a very good advantage.

In this malt of Somth Daliota the srass dries out about Sept. 1st, and then is when l think the silo comes handy, although they need not be fed so much later on wheil they get the coln stalks from the field. I fill.d the silo with con, bur it was almost too ripe and I mixed in about forty barrels of watel. I started feeding immediately after filling, giving them hati a bushel twice a lay. once after milking in the morning and when getting them in the evening. When corn stalks came I did not feed them so heary. About Nor. 1st I started to feed some alfalfa hay, which lasted until ajout March 1st. This goes very good with the cows, fed just betore turning them out. After the corn stalks were cleared I increased the ration to a heaping bushel basket for two and have kept it up to the present time. I have milked cows in South Dakota for two winters, once with and once without a silo. The following is the record from Sept. 1 to April 1 for the iwo winters:

\section{Without a Silo.}

30 tons prairis hay...................... \$120.0n

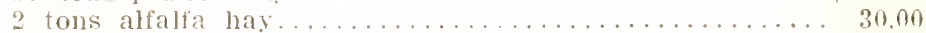

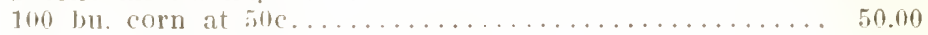

40 bur. rys ant i ton bran, mixed............ 55.00

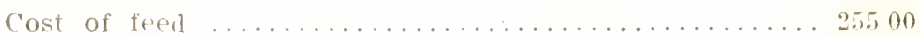

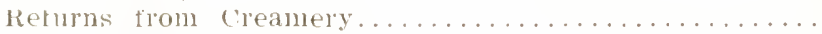

$\$ 350.00$

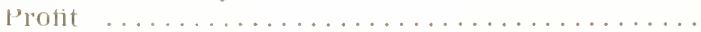

$\$ 95.00$

With a Silo.

Cost of filling silo......................... $\$ 200.00$

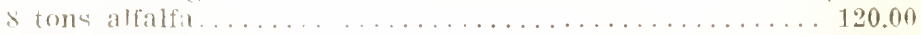

Cost of feed .......................... 320.000

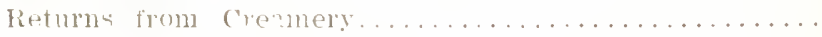

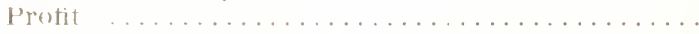

Protit for first yoar.................

$\$ 560.00$

$\$ 240.00$

95.00

Increase in jofit tonm silo.

$\$ 145.00$

Note.-I have allowed enough in the enst of filling silo, one-tenth of the cost of the silo, although I bulieve it will last longer than ten years. Youls truly'.

EIJAS JONES,

Mitchell, S. D., Box 35. 
Inuiana Silo Co., Axperson, Ind.

Gentlemen:-ln reply to your request for facts concerning the profits of the silo, will say in 1908 I purchased a $12 \times 24$ Indiana Silo of your agent, J. W. Sligor. I have filled it two years. On December 1st, 190s, I opened my silo and found that the ensilage had kept perfectly. My neighbors who had previously ted ensilage pronounced it first class and it certainly was.

In regard to my feeding operations will say that it did more for me than I expected. I fed 10 all kinds of stock with fine results. The bunch of 10 cows which I fed on ensilage last winter came out in the spring in 50 per cent. better condition and yielded $\$ 100.00$ more milk than the

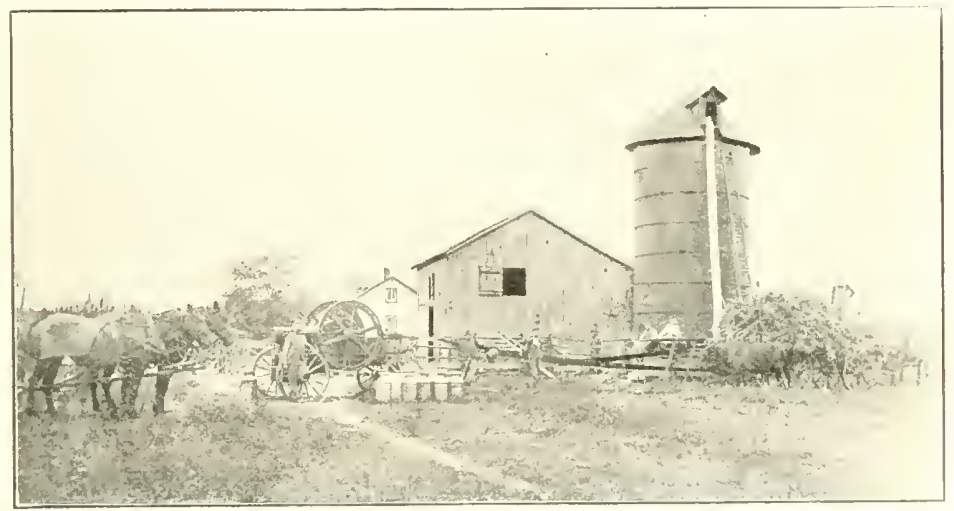

Edgar Dennis' Outfit.

same bunch did the year before on corn amil other feed. 1 find it as valuable for fattening purposes and young stock as for milch cows. It fur . nishes a succulent feed through the winter, which all stock relish. It is doing the same for me this winter that it did last. It is handy to feed and always ready; there being no waste, it goes so far.

A lew year's ago the silo was unknown in this vicinity, mine being one of the first erected. Since seeing their good qualities and benefits several went up last year with prospects for more the coming year. I can recommend your company to all prospective purchasers for fair dealings and comteous treatment. Under separate cover I am mailing you a picture of my silo, taken while we were filling it this year. If you can use it do so.

Thanking you for past kind treatment and wishing you success in the future, I aur your friend, EDGAR DIENNIS,

Fffingham. Ill.

\section{BUYS SILO FOR RENTED FARM.}

InDixa Silo Co., Axpersox, IND.

Gent'emen:- I operate a daily and keep several cows and live on a lented farm of 240 acres. In 1907 I purchased one of your silos at my own expense and will positively say that I saved enougly the first year to pay the cost of the silo, compling the cost of feeding previous years, and will say that I never had my cattle go through the winter in as fine shape 
before. For convenience there is nothing like it and I am always ready to give the Indiana silo people a word of praise for selling me one of their most valuable articles. Yours tor success,

OSCAR C. FRIDDLE,

Parker, Ind., R. F, D. No. 20.

\section{NO WASTE AT ALL.}

IXHAMA SILO ('U., AXDERSON, IND.

(ientlulen:- The cheapest teed for any live stock mpon the farm is ensilage lised from the mondan silo, I can say without a doubt that the Indiana silo is a good and llying investment, as the corn can be harvested and canned up in the re'y best stage and when the days are long and generally fine weather to work. It can be put in the silo cheaper than it cam be harvested any other way, as it saves shocking and only has to be handled once and that settles it until you want to feed it, and then it is stoled in such a small place and handy to feed. The corn can be chit right down to the grounc? and thele is no waste at all as the stalk, cobs and all are eaten with a relish. I am sure I can feed twice as much stuck from the same land as I could before I got my silos. I have had one silo, this is the fourth season, and I put up the second one two vears ago. 1 feed beel cattle from the one in the basement of the barn and the other is on the gromud Hoor and we leed dairy cows and our horses and stock cattle from it. I have fed from one to three carloads of steers for market each season since I have hal a silo. This winter I marketed three carloads of steers at Chicago on January 12th, and 1 still have 60 head of cows and stoek cattle, which I intend to carry through the winter, and I think I have wlenty ol feed to take them through, and I have six work horses and two mule colts.

As to the profit in feeding steers, of course sometimes I make more than at other times. The main thing is to buy right and feed right and sell at the right time. The cattle must have a comfortable place to lie down. This winter has been severe to feed since lecember 1 st. The ensilage is a tine feed for dairy cows and is the chrapest feed one can get. Of course, you should feed some ground feed with it for a balanced ration, though it saves buying so much ground feed. They will eat so little hay as the silage is bulky and fills them ilp. Some fellows ask me, do you put in corn and all? I say, yes, sure, and they look surprised and say, jsn't that expensive? I tell them I only wish there was more corn in it.

The nice lnart of it is, the corn all goes through the cattle and goes back on the land in such fine sliape that it is worth a whole lot for keeping up the farm, and I value the feed very much for growing young stock. There is no tanger of indigestion. We are dairying upon a small scale as we have not the help to rum many cows. We milked an average of about 10 cows last year and in the year 1909 we sold 2,28S pounds of butter ard roceived $\$ .22 .00$ for it at the srocery. and the grocer had cus. tomers for it. IIT had a great deal of hutter and milk and I value the sepalated nilli worth a great beal for ralves and pigs. Our cows are very conimon and some of them were just baby cows, not two years old. I cal say that my farm is getling better al the time in place of running dorm since I have had the silo. I am sure that I can moduce twice as much wyon it now as I could when I bought my first eight vears ago. I fill my two silos this year with about 20 acres of corn and they will hold abont 230 tons, and the price of feed is, hay $\$ 15.00$ per ton and corn $56 \mathrm{c}$ per bushel. Silage is worth $\$ 5.00$ per ton.

El) GOSS,

Rochester, Ind. 


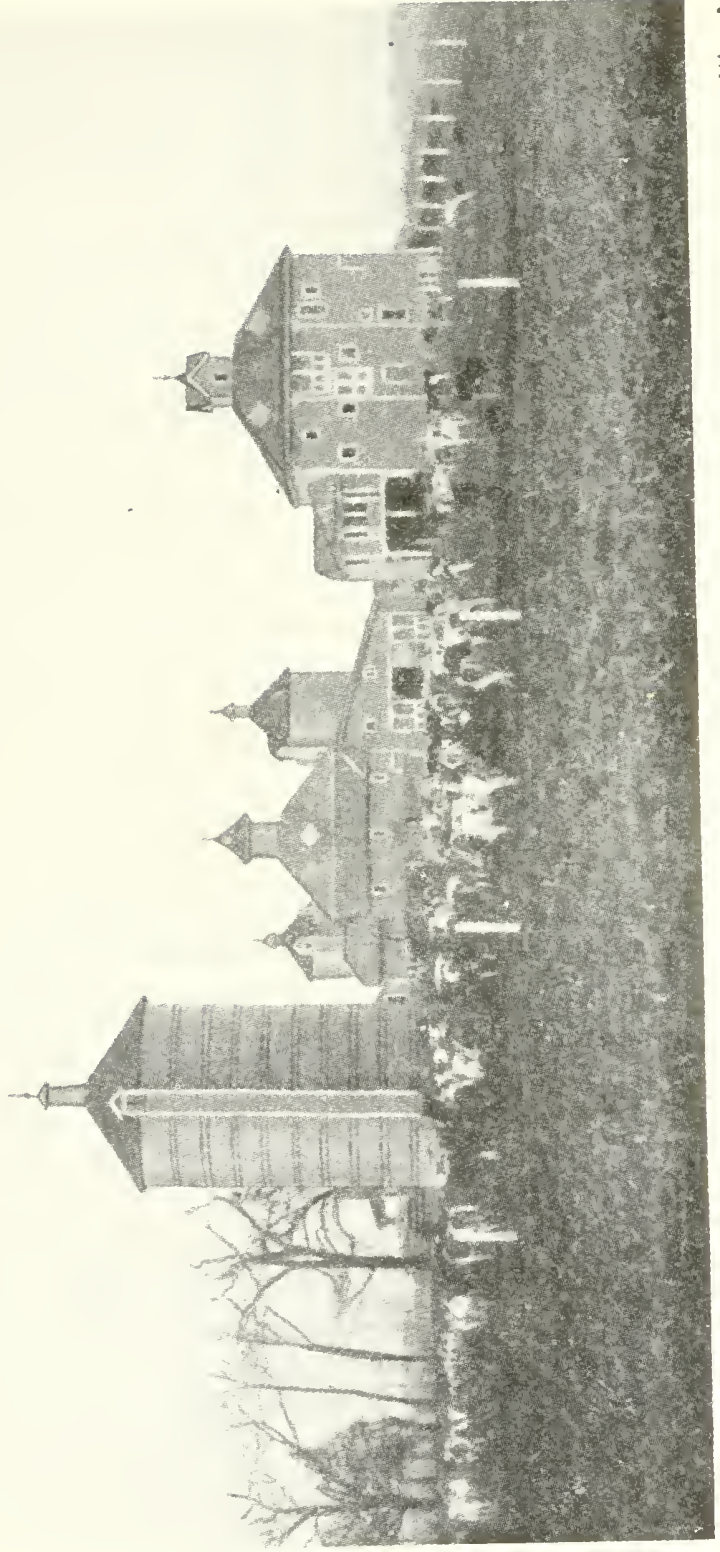

ఏ

is

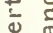

으

ज

is a

30

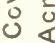

$\therefore$ 운

त)

ᄃ

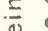

on 3

어

I

O

(5)

$\frac{1}{15}$

I

58

I

14

I 0

$-0$

¿

त)

๑)

$\therefore \frac{5}{\pi}$

D

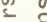

을

in

क

$\Sigma \Sigma$

$\rightarrow 2$

$4 \frac{0}{\circ}$

$\xi$

赔

4

$\stackrel{4}{5}$

ᄃ

İ

$\times$

ते

i क

응

क

ํㅗㄴ 
Intiani Silo Co., Axderson, Inl.

Gentlemen:- I have been a breeder and dealer of registered highsrade Holstein cattle for 10 years. I have been a user of silage for the past tive years, and want to give an idea of the cost of producing silage.

l start in by charging myself $\$ 5.00$ per acre for my land, $\$ 2.00$ per acre for plowing, $\$ 1.50$ per acre for seed and planting, $\$ 1.50$ per acre for cultivating. This makes my corn stand me $\$ 10.00$ per acre, standing. I raise on an average of 20 tons of coln to the acre, which makes it cost me 50 cents per ton. It costs me 40 cents per ton to harvest the corn, put it in the silo, pay interest on my silo, machinery and all expenses considered. This makes a total cost of 90 cents per ton in the silo.

lly farm consists of 140 acres. I have 5 acres covered with buildings and feed lots, the balance of 135 acres of solid corn fodder. 'This year I fed 235 head of cows and heifers from this 135 acres of corn put in silage. This would cost 90 cents, making an average cost of 90 cents per head per month.

I will say that previous to using silage, I fed my cattle corn meal and bran, tame hay and corn fodder, which cost me an arerage of $\$ 17.50$ per ton, and I will say that my cattle do much better on silage feed at 90 cents per ton than they did on the dry feed at an average of $\$ 17.50$ per toll.

I am satisfied that manure from cows fed on silage has more pinosphate than where fed on dry feed, as they eat the entire stalk of corn when put in silage, which contains phosphate. This they do not eat when fer dry feed, I am not authority on this point, but this could be determined by the experiment stations. Will say that three men have fed 500 head of cattle on the silage feed, and I an satisfied that it would take 15 men to feed the same inmber of cattle whele the corn fodder had to be handled in ans other form.

Now, a valuable item on the silage feed is that where cows are fed on silage leed in an open feed-lot in the summer, flies will not torture thenl, as they do not like the odor of the acid that comes from the silage.

I an not overestimating when I say that I save 50 pel cent. of my feed by muting it into silos gresn, in preference to cutting and shocking it. Wheresy the san eraporates and leaves the body of the stalk hard and dry, anul it is immusible to make the cattle eat it after it dries out.

JAS. DORSEY,

Gilberts, 111 .

\section{SPEAKING IN REGARD TO SILOS.}

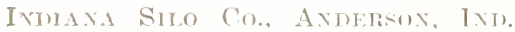

Gentlemen:-1 purchased a 30 -ton capacity silo from the Indiana Silo Co. tom years ago and I think it is the best pulchase I ever made. It takes thlee acros of good ensilage corn to fill it, which will feed 9 cows for one winter. Cows fed on ensilage will do as well as if they were on pasture, it not better. When cattle are fed on ensilage during the winter, in the suring they ale in A No. 1 condition. If I were to feed hay instead of ensilage to ny stock it would take at least 25 tons, which at the present frices would mean $\$$ mon.000. To feed ensilage costs less than to feen hay and gives far better lesults. My horses eat ensilage in preference to oats.

Surely, no farmer can invest his money in anything that will pay him better than a silo. Yours very truly,

WM, LEVENTRY, Johnstown, Pa. 
Indina Silo Co., Andersox, Ixd.

Gentlemen:- Yours of January Isth at hand and in regard to same will say that I am very much pleased with my silo. It certainly is a money maker. In fact, I would not part with it at any cost. There is only one way of getting the full benefit out of the corn stalk and that is the cutting ul in the fall and retaining all the life of the stallis be ow. Yoll may see what my silo has done for me. My silo is $14 \times 24$ and 4 feet in the ground, and when properly filled I can feed 20 head of cattle and 4 heifers, I bull and a little to 7 horses, from November until June.

My milk checks for four winter months were never over $\$ 30.00$ per month before I had the silo. This was three years ago. Now my monthly checks are all over $\$ 100.00$ from 20 cows in the winter months. My silo brought me a profit of $\$ 300.00$ per year, so I cannot praise your silo too much.

Furthermore, I wish to state that your silo is the cheapest silo on the market today. I have had numerous callers from far and near and have had it inspected by several farmers and every one said it was better and cheaper than the one they had.

I have some neighbors who would like to have a silo the coming season and would very much like to have your catalogue and price list. I think it would be a nice thing to have an agent who has a silo standing on his premises as I have. At any rate let me hear from you in the near future and give me youl opinion on this question as I am very much interesterl. The agent whom I bought my silo of was not trusted, otherwise he could have sold lots of silos around here. Truly yours,

JOHN L. DE TRUGE,

Sheboygan, IVis.

\section{FOR THE BENEFIT OF OTHERS.}

Indixa Silo Co., Axpersun, Ind.

Gentlemen:-Not for the benefit of those who use the lndiana Silo do I write this article, but that some inquiring brother may catch a lay of light on profits by utilizing the corn crop in silage.

It is a good business proposition to save what we make. This cannot be done in any other way as well as by a silo. Our chemists tell us that 40 per cent. of the feed value contained in the stalk and ear is below the ear. If handl $d$ in any other way than silage it is almost a total loss for leekl. We have used the Indiana Silo five years, never losing any silage only a smal! amount on top caused by decomposition during the siloing process. I tast year on a carload of 935-1b. steers fed by myseli for 120 days, made a daily arerage gain of 3 lbs. each. Their ration consisted of a small amount of clover hay and all the coln silage they would eat. The grain ration was 4 lbs. cotton seed meal and 4 lbs. of corn meal each.

This year we are feeding 22 head of 60()-lb. heifers. Alter feeding 39 days they had gained $2,498 \mathrm{lbs}$. The ration is about the same as given to the steers last yeal. Because of the high price of grain I would not attempt to fatten beef cattle without silage. Not only because of the nutriment derived from it, but it is an appetizer, keeping the stomach and bowels in good condition. Before filling we always remove smut and leave all blasted stalks in the field. In gool com we usually pull off about one-half of the best corn to feed to fattening hogs, which we manage to have on hand. Time to fill is when the largest per cent. of stalks have reached their mature growth and show signs of rrying up. Chop as near the ground as possible in order to gat the heavy part of the stalk in silo, 
cut it fine and put the best man in the silo to keep it level and tramp abso. lutely solid.

Sometines it is difficnlt to decide on the size to buy. Be sure and buy large enough tor those who use silage to increase their stock. Locate the silo so the feed can be hanled with trucks or some means without carrying it.

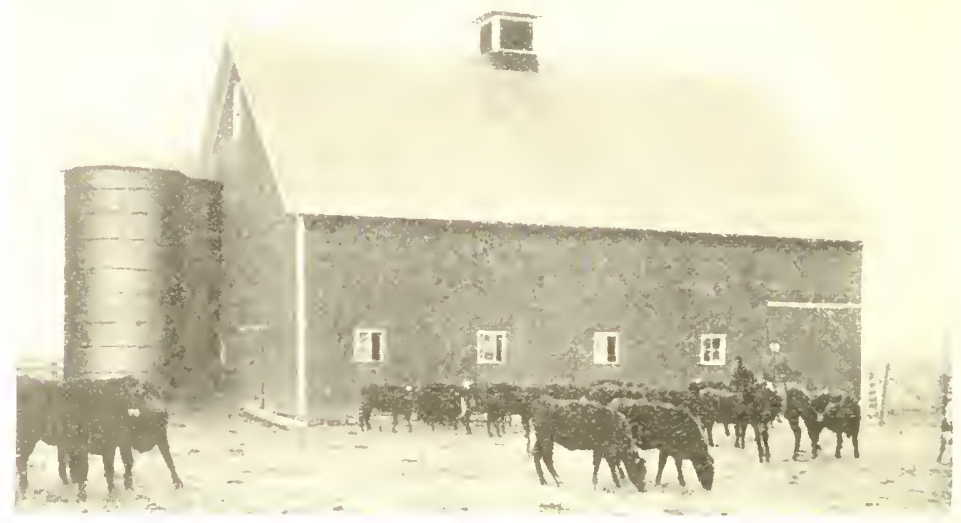

L. C. Carter's Cattle and Buildings, Salem, Ind.

With a silo the corn is moved from the land earlier, thereby giving a better ofportmity to prepare the lind for whert. A greal many more head of stock can he kelt on the farm, thereby making more l arnyard. manare to keret me the tertility of the soil.

LEWTS C. CARTER,

Salem, Ind.

\section{AB!E TO INCREASE HERD ONE.HALF.}

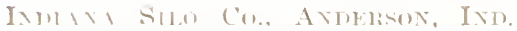

(imllemen: I will try to give you a few lints as to why l think the silo has paid me:- Ithen I bought my silo I kept about eight

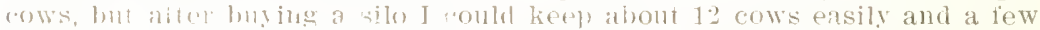
otler stork, such as shenl and catfle. But I went to feeding my cows

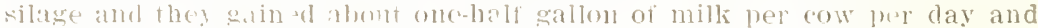

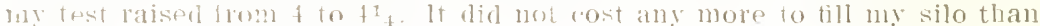

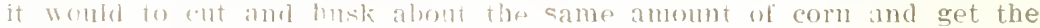
toklerer ont in the winter.

1 do mol beling a man (an makt a success at dairying on a small farm mluss hr. lyas a silo. Thro lur hats all the leaves and stalk to feed, where the stork dio not tilt the stalks in racks outside. There is no loss in handling as otherwise. Thum the silo tillod enables you to do your own feeding wilhout the airl of a hand.

I would enclose che of my photos of my herr and silo, lut I have been ill with the grip and memmonia for the past month.

I believe thial this is a true statement to the best of my knowledge. very sincerely yours,

ROBIERT N. CIRRY,

Mechaniesburg, O. 


\section{REGRETS HE DOESN'T HAVE TWO.}

Ixdana Silo Co., Axderson, Ind.

Dear Sirs:- Thinking you might be interested to hear what satisfaction my silo is giving, also what feeding results it has produced on a bunch of short fed steers, I will give you a brief outline as to what and how I feed them; also, the weights when put in to feed and when sold. The 5 steers weighed 6,440 lbs. November 8th, 1909, and were worth $\$ 4.00$ per cwt., or \$257.60.

We fed each steel 42 days, as follows:

Daily teed per steer.

Weight of feed.

32 lbs. silage. . . . . . . . . . . . . . . . . . . . . . 1,344

18 lbs. corn. ........................... 756

8 to 10 lbs. clover.......................... 400

December 20th the steers were weighed and sold as follows:

3 steers, 4,530 lbs., at $\$ 6.50$.

2 steers, 2, 610 lbs., at $\$ 5.50$

Total, 7,140 lbs.

I did not keep any account of the gain made by the 10 hogs I had with them, but would judge they gained at least $10 \mathrm{lbs}$. yer day or $420 \mathrm{lbs}$. of gain, and only had two baskets of silage in addition to what they got from the cattle.

I had some cows feeding, but did not keep an exact account of their gain, but know they did equally as well as the steers. Must say silage is one of the grandest, cheapest feeds I ever fed and only legret that I did not put up two silos instead of one.

FRANK T. EASON,

Mgr. Lawndale Stock Farm, Des Moines, Ia

\section{PAYS 200 PER CENT FIRST YEAR.}

Inumaxa Silo Co., Anderson, Ind.

Gentlemen:- I will send you a statement of my silo feeding:

Silo, September 1, 1909.....................\$\$ 300.00

9 acres corn in silo......................... 150.00

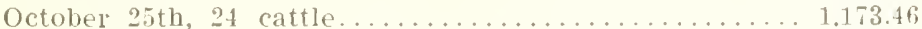

Hogs on hand............................. 100.00

Dry coln to cattle.......................... 300.00

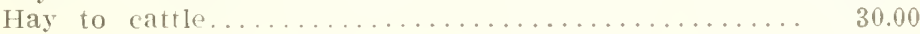

Total

$\$ 2,053.46$

Halch 29th, 10 cattle sold. . . . . . . . . . . . . . .\$1,799.50)

Hogs that followed cattle................... 402.50

Hogs left on hands........................ 100.00

Silage fed to 3 milch cows 6 months............... 30.00

22 sheep fed 5 months...................... 15.00

Silage fed to horses...................... 5.00

Income . . . . . . . . . . . . . . . . . . $\$ 2,352.00$

Expenses . . . . . . . . . . . . . . . . . . \$2,053.46

Silo paid for and.....................\$ 298.54

Well pleased with silo and lik? to use the feed. Everything did well on it and I got it paid for and a good profit.

J. W. ESPEY, Palestine, I11. 


\section{GOOD REASONS.}

Induaxa Silo Co., Axuelsox, Ixp.

Gentlemen:-l bought a silo of you four years ago and it has saved

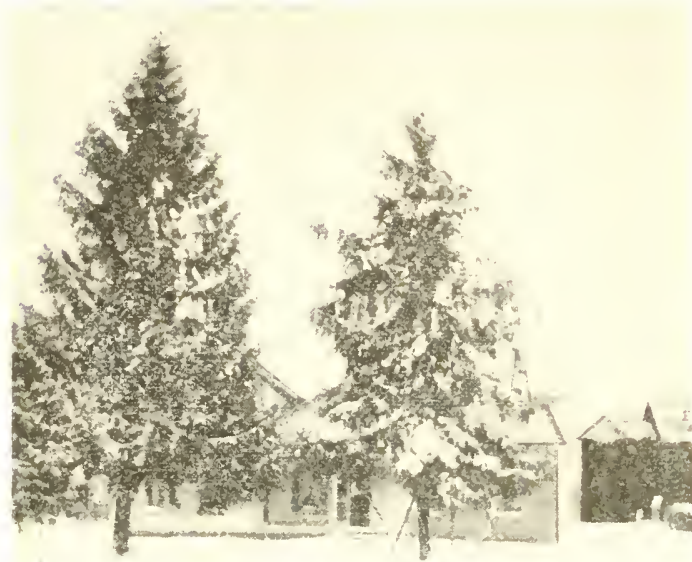

Farm Home of F. B. Lewis, Vandalia, Mich. me its cost and more. It costs me $\$ 200.00$ each year for the corn to put in it aind to pay for filling it. I and some of my neighbors have bought a silo filler, so it won't cost $\$ 200.00$ next year to fill it.

1 bave $1 \mathrm{~s}$ cows and heifers and 1 bull and the silage lasts until pasture is good in the spring. I have five horses and I feed them silage instead of corn in the winter. The cows and horses would eat 25 tons of hay, which costs $\$+0.00$ per ton, and sometimes more, which would be $\$ 250$ or $\$$ in saved right there by the use of the silo. Now, if 1 had nothing to feed the cows hut hay and fodder I would have to bave corn and oats ground. That would cost ne something with corn at $60 \mathrm{c}$ to $75 \mathrm{c}$ per bushel.

When I teed silige I give them a little hay about once a week for a (hange. Silage saves your coln, oats and hay and is as good as corn or oats and yetter than hay, so it saves money. Sme of its advantages are these:

First It is as good as oats and corn ground up and it costs less.

Second. It is better than hay and costs far less.

Third. It is so rich that but little is required.

Fourth. A silo talies up far leis room than a han wonld to hold the same quantity of feed.

For these prasons and many othors I prefer silage to any other feed. Yorles truly,

F. B. LEWIS,

Vandalia, Nich.

\section{CATTLE AND SHEEP DO WELL.}

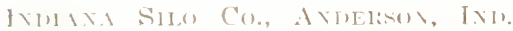

Gentlomen:- At your lequest I will endeavor to let you know something of what I hink of an fncliana silo. To commence with, will say that last you as we had a vely short coln rop and not much hay, and had several head of cattle and shesp we wanted to kees over winter, we con"lurtod there could nevel lie a better time to experiment with an Indiana silo than then. Did not take the notion until late, but as we had a late piece of com we got our silo up and filled in good shape. We set it on a cenent. basement with cement floor, which added 18 inches in height to its canacity. As to figures showing the actual gain in weight, I could not give them. 
Our experiment was to see if our cattle and sheep would live or die by trying to take them through the winter on silage, as it, with a little straw and fodder, was all we had to give them. I live in Russiaville and have my farm rented to C. G. White, each of us having half interest in the stock. I went every once in a while to see how they were doing. I must say they did not only live but did as well or better than when we had plenty of corn and clover hay to give them. I have been aslied if the stock would clean it up or not. My attention was drawn to that one cold morning when I went out to see the cattle after they had been led a little while, by making, a mistake and stepping in the trongh; you can guess at the rest. I said to $\mathrm{Mr}$. White there is no doubt about the cattle eating this stuff up clean. The sheep would clean it up perfectly clean and did as well as the cattle. Some ask it there is danger of over-feeding. After they get used to eating it there is certainly no danger for we surely gave it a good test with one calf, a Poll Hereford that came late in the fall, and we let it run with its mother. It would eat with the cows until they would clean up all we gave them and then it could get through the mangej" and eat where the silage was thrown down until it was satisfied. It kept this up all winter and I never saw a calf do better or look nicel that ran with its nother on good pasture. Everything on the place will eat silage.

In conclusion, must say I would not think of doing without an Indiana Silo, and gladly recommend them to any farmer that likes to raise nice stock and keep up the fertility of the soil. Yours respectfully,

$$
\text { G. II. LTBROOK, }
$$

Russiaville, Ind.

\section{MILK CHECK INCREASED.}

\section{Jxilana Silo Co., Anderson, Ixn.}

Gentiemen:- I bought a silo from your company about two yeal's ago. I can say this much about the Indiana silo of mine, that it has easily paid for itself during the time I have had it.

My silo is $14 \times 20$. I have a 40 -acre farm. Belore I had the silo l had hard work to feed 7 cows on my farm. Now with the silo I can leed 16 cows easily and raise 4 to 5 heiter calves every year besides, which I had to pasture somewhere else before, and paid from $\$ 2 \$ .00$ to $\$ 30.00$ every vear for pasture.

Now with my silo I save that and can keep more cows besides, and the calves do so much better with the addition of silage. My cows show such a difference by the use of silage that my neighbors don't believe me until they see my checks from the creamery. I am milking fo cows now, which brought me last month, December, 1909, \$152.35. Could never do that without my silo. Besides, I saved last year on my mill feed, $\$ 134.00$. I can't see how it is that so many dairy falmers go without a silo. They are Insing money every day without a silo. Take it last smmer'; it was so dry, no pasture, but my silo was nearly half full yet, and I could feed my cows a full ration right along and got big milk checks, where my neighbors hardly got any checks.

Now, as far as the silo itself, I don't think there is a better one built than the Indiana Silo. It keeps the silage perlect. Before I bought mine I went all over to see which was the best, but couldn't find any other make as good as the Indiana Silo. Take for instance the doors; they are surely good ones. Close up easily and furnish a fine ladder to climb up on and can never get out of shape. Their staves fitted so perfectly that it was no job to put the silo up, which is quite an item, as I have seen here with others. If l wanted to buy another the Indiana Silo would be my silo. Respectfully 


\section{LIKES IT FOR HORSES AND CHICKENS.}

Indiana Silo Co., Anderson, Inu.

Gentlemen:- For the past six years I have been uting the Indiana Silo and consider it one of the best investments l have ver made on the farm. The longer 1 use it the more 1 am pleased with it. My experience with it has always been in winter leeling and have fed silage to dairy cows, lattening cattle and young stock and like it very much lor chickens. Occasionally I feed it 10 my horses and they sem to relish it very much. I have always nsed corn silage and in all my experience consider that silage, in so lar as it is a rough feed, is the most economical way of handling roughage.

The dinemsions of the Indiana silo which I put up are 24 feet high and 16 leet in diameter. Below the silo proper 1 made an excavation of 3 feet. The silo sets on a foundation of stone, being 1 inches thick, the wall inside being cemented. In putting up the silo it was set a little within the center of the wall. Generally it is advised to bevel the wall where the lolindation meets, particularly if the foundation is of any great depth. Although mine is not beveled I have never had any spoiled silage where the foundation and silo proper meet.

It is possible that in this region where the corn does not make so much stalk, that it costs more per ton to fill silos than it does farther sonth, yet lrom my experience the cost per ton of producing silage is very cheap in this region. I tigure the cost per acre of growing corn for silo as follows:

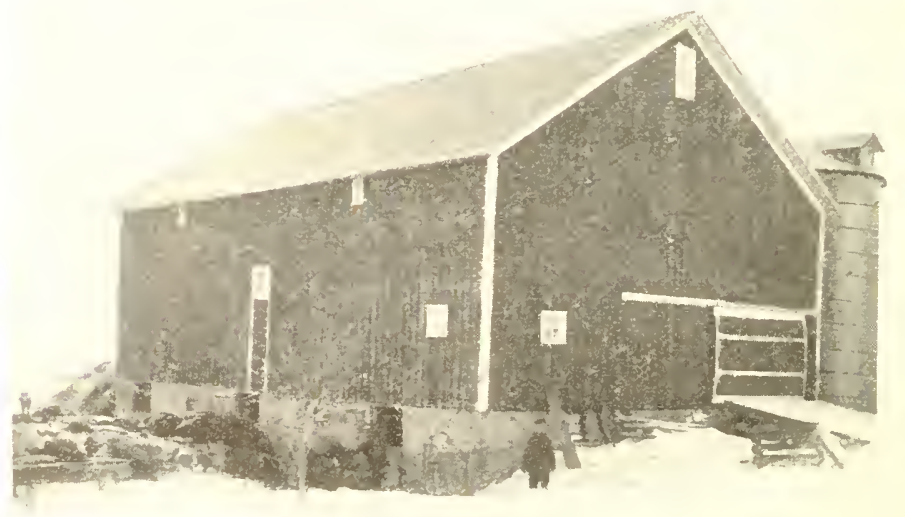

In the Far North-Thos. Dailey's Barn and Silo, Lewistown. Minn.

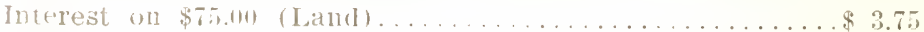

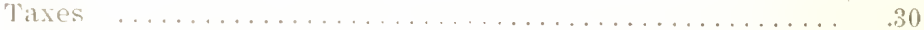

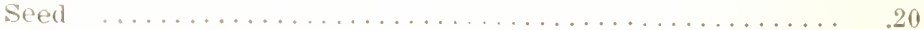

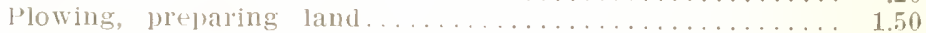

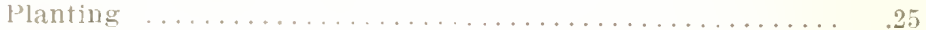

Gultivation ............................. 1.00

rutting corn and filling silo................... 3.00

Cost per acre......................\$10.00 
Estimating an acre of coln to produce 12 tons of silage, which is a low estimate for yield, the cost of silage per ton would be $871_{2} \mathrm{c}$. I feel that I have been liberal in all my estimates.

Certainly this is the cheapest form in which feed can be put up, the entire plant preserved in a palatable form, and it has a beueficial effect on the digestive systems of animals. In all my feeding 1 feel that I have realized a good big profit and I consider my investment in the Indiana Silo one of the best I have ever made on my farm. As to the durability of the Indiana Silo, I believe, considering the high grade of material of which it is made and the workmanship put on it, that with reasonable care it will last 30 to 40 years.

TIOMAS DALEY,

Lewiston, Minn.

\section{OVER 1,000 LBS. MORE MILK PER COW.}

\section{Indixa Silo Co., Axpersox, Ind.}

Gentlemen:- Having been requested by you (Indiana Silo Co.) to write an article as to the profits the Indiana Silo has given me, I thought 1 would try to give a few facts as to my profits.

By paying twenty-five dollars $(\$ 25.00)$ to a man owning an ensilage cutter and engine I had a 10-acre field of green corn put into the silo. I suppose some of you who have not had experience with the silo will say that there are many other expenses connected with the silo and the filling of it, but that is not the case. Of course it takes a good deal of help to fill the silo, but I believe in the old proverb, "Nake hay while the sum shines." By putting in several days of good work filling my silo and exchanging work with my neighbors who had silos to fill, I had the field of green corn stored in the silo for the "rainy days" and every particle of the corn being utilized into a succulent feed of the highest quality. If I would have cut this corn for fodder, but taking the risk of being frostbitten before ripe, as it was a late piece of corn, I would not have needed the help of the neighbors, but would also not have had hall as much feed and of a less nutritive value. Another gain I made by putting the grain into the silo is this: I planted cow peas with the corn so as to make a larger bulk yield per acre. The peas grew so thick that some had crept along the ground. It was not a hard task to cut the peas and corn with a binder, but could not get quite all of the pea vines. A little shower of lain after the corn had been taken off of the field gave the remaining pea vines a second growth. I turned the cattle into the field and it made them good pasture for several days.

A year ago last fall I had a similar experience. As soon as the corn was cut I sowed the field in wheat. This wheat made 17 bushels per' acre. If I would have cut the corn for fodder the wheat would have been sown at least a month later giving a poorer chance for the wheat.

Otten when I am feeding ensilage on a cold, blustery day I think of the time when I had to go out into the cold, "rain or shine," to haul up feed; and the worst of it was to see the cattle waste one-half of it, while now they eat the stalks and all.

For the last tliree years I have kept a lecord of my herd of cows, and the figures plainly show the results. For the year 1909 (first year feeding ensilage) my herd of 18 cows gave $20,200 \mathrm{lbs}$. of milk more than in 1908 . This makes a great profit and I am sorry that I did not buy an Indiana Silo five years ago, the first time the agent wanted to sell me one. I think, however, that my investment in the silo was a good one. I remain yours respectfully,

LOUIS KLEINER,

Greenville, Ill. 
INDina Silo Co., AxDerson, Ind.

Gentlemen:-I, as the ownol of a small farm, would not attempt in this day and age of the world to rum a dairy farm without a silo.

In the year of 190.5 I started a small dairy. At the beginning of the winter months I thought I would have plenty of feed; in fact some to sell; but long belore the winter months were past I discovered that we would have to buy feed, alfalfa and clover and some grain.

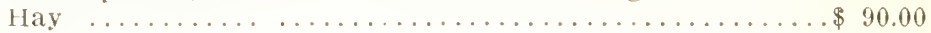

Grain .............................. 100.00

In the year 1906i I purchased an Indiana silo from the Indiana silo Co. At the begimning of the winter we thought we had scarcely half enough leed, but in the jatter part of the winter months we were surprised to find that we would have some feed for sale:

Hay, amounting to........................\$185.00

Grain amounting to....................... 75.00

Making a total gain over the previous year of

\begin{tabular}{|c|c|c|}
\hline $11 \mathrm{ay}$ & 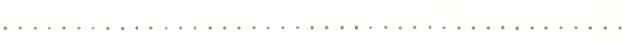 & $\$ 90.00$ \\
\hline llay. & 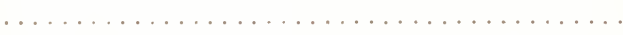 & 185.00 \\
\hline Grain & 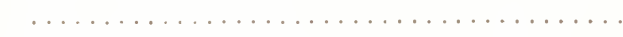 & 100.00 \\
\hline Grain & 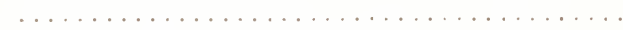 & 75.00 \\
\hline
\end{tabular}

All due to the silo, sayilg nothing of the increased fiow of milk. The following ferat's luave shown similar results.

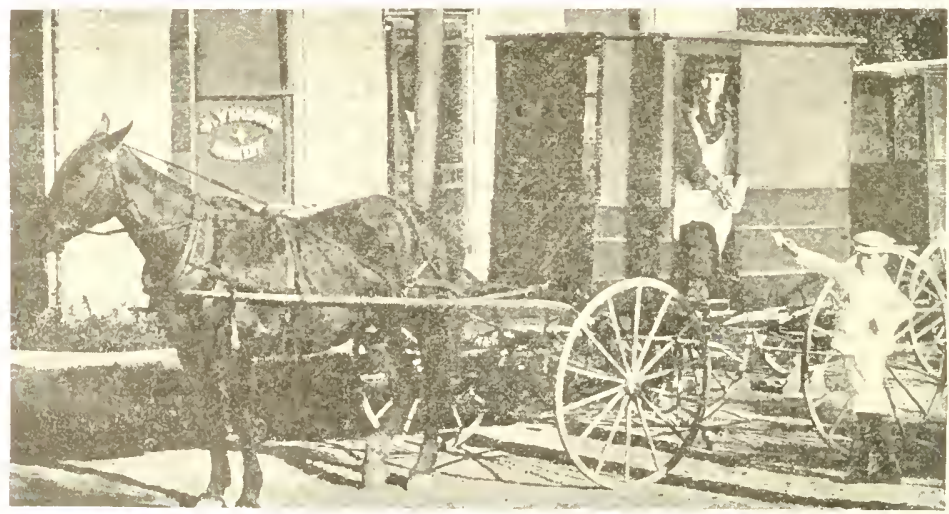

L. S. Kellum's Dairy Wagon, Bethel, Ohio.

1 can truthlully say that the silo reduces the cost of feed 33 per cent, and increases the flow of milk at least 33 wer cent., making a gain of biti per cent. over tho old way of feerling. No man can make dairying a complete surcess without a silo. During the year 19um my silo has been an inexpressible protit to me. My neighbors who had no silos told me that I would not have corn enough to fill the silo. They had a little more corn and about hall the number of cows. Before the winter was over some of them spent as much as $\$ 300.00$ for feed, while I had some to sell. With the "silo" the farmer can produce his own protein on the farm by filling 
the silo with corn and soy beans mixed load about, thus saving the great expense of hauling the protein to the farm in sacks costing from $\$ 1.75$ to $\$ 2.25$ per 100 pounds.

One acre ol coln in the silo is equivalent to 5 acres of pasturage, as I have watched closely during the past five years. After turning the cows upon pasture can see no change in the How of milk, but the test of the milk will be from 1 to 1.5 per cent. higher in winter than in summer. I can proudly say that my silo is of vast profit and importance to me.

Expressing my gratitude to the Indiana Silo Co, I remain yours sincerely,

L. S. KELLUM,

Locust Grove Farm, Bethel, O.

\section{NEIGHBORS SAID HE WAS CRAZY. WAS HE?}

INDIANA Silo Co., Anuerson, INu.

Gentlemen:- I have had an Indiana Silo for two yeals. They surely are a success, and I do not believe there is a single Iowa farmer or a farmer in this northern comntry that can afford to be without a silo.

One year ago this winter during the months of January and February we had 8 and $y$ cows. Our cream checks were $\$ 50.00$ per month on silage where on dry feed we only realized $\$ 16.00$ and $\$ 18.00$ per month last spring. 1 lelt as though one extreme would follow another, so I mepared for dry weather by putting two acres of clover in my silos. It made me 24 tons of good feed. The neighbors said I was going crazy to put that good clover in there to rot, but when the dry weather did come in August and September I reaped my reward. I was milking 9 cows, one of my neighbors was milking 19 cows. I compared cream checks with them. They had clover meadow that they used. I fed the clover silage, and my checlis were just double what theirs were per week, and our cows by this time were all strippers excepting one. I could not make dairying profitable without a silo. It is the cheapest feed that can be used for all kinds of stock. Yours truly,

VIOLA R. ONTHANK, Grinnell, lowa.

\section{MAKES MONEY TWO WAYS}

Indixa Silo Co., Axnerson, Ixd.

Gentlemen:- We erected one of your Indiana Silos in 1908, which I find to be a great benefit to my farm. I now see why it always took so much to keep ny stock over winter. A silo will bring in the money by the good results and save nough in one winter to pay for the building.

The cost of feed has so advanced that we must take into consideration the best method of saving feed. A silo will funish you a lasting feed with no waste and always ready to be fed and as cheap as call be fed. It can be fed to all stock and is fine to fatten poultry and make hens heap up the egg basket. Belore erecting my silo I always filled my barn full of hay and then when time to shred would fill everything full of shredded fodder and by spring everything would be empty and I would be compelled to turn in on my pasture early in the spring, but now I let my pasture have a good start and my barns have not been empty since l have had the silo.

For the past two years we have sold our milk to the Indiana Dairy Supply company of Anderson, and since feeding ensilage it has raised our test 7 per cent. more than we ever tested before and the flow of milk is twice the amount per cow during the winter.

I do not see how any one keeping stock can afford to be without a silo. Wishing you succes, I remain yours truly, 
Inmaxa Sho Co., Axdersox, IND.

Gentlemen:-The larmer that once uses a silo is convinced as to its necessity to the farmer.

My experience dates back to 1900 and 1901, which two years I used a silo. While in the dairy business at Marion. Ind., and the two years I used the silo convinced me that no farmer could profitably milk cows (or feed (attle) without the silo. When I came to soutlwestern Nebraska, where I now live, I realized the areat need of the silo for the farmer and feeder, so I set to whiting all the manufacturers of silos for prices, etc., and decided to buy the lndiana silo, and by getting ont and hustling I sold enough to my neighloor's to make a carload and by so doing the company paid freight on the carload to my station.

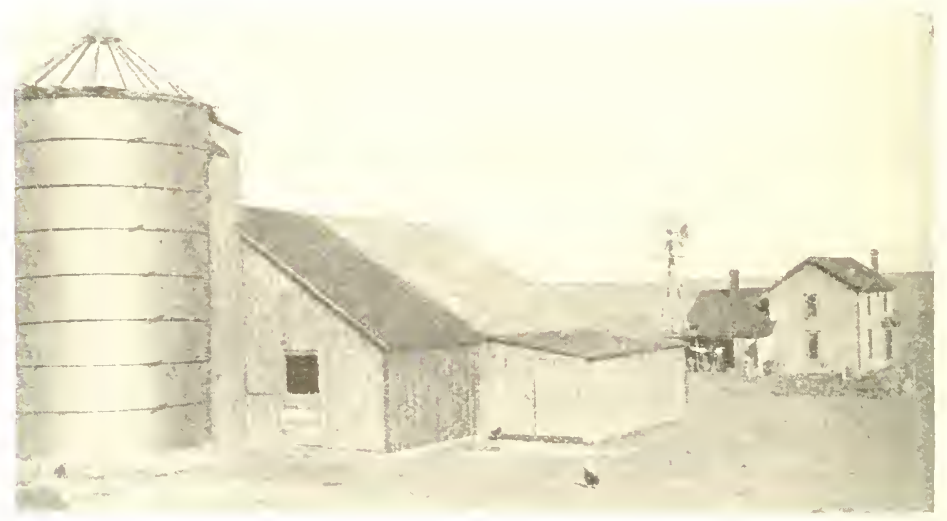

A. Dillman's Prairie Home. Trenton, Neb.

Will just tell in a fel words what my silo did for une in the one winter's 11st which I have used it. With nine cows tred silage for six months 1 had for my silo and matter witl butter fat sold and by account kept of investuncut in silo. ("utler and expense of filling and cost of raising corn put in silu my teed cost not 10 excesd $\$ 3.50$ per ton and now as I consider my silo and (ntter llate for the lirst year, my profits from this on will cortainly be oncouraging, and while I consider the silo a necessity in the way of dollars and cents saved, I also consider it a convenience and saving of labol.

1 enclose you a ploto of my harn and silo showing that I did not liave to dig my feed ont of the snow this winter. hut led so tons of fine feed fom my silo without setting ont in the bas weather. Ths cows that were forl silage protuced me butter fat to the amount of the investment in-silo, cutter, etr. I could have sold, any time after March 1st, to the butchers at te ler 1 b., as they wers any of them fit for the block at that time. Respertful?y yours.

A. DIITMAN,

Trenton, Neb. 
BLACK HAWK FRUIT FARM, MILO F. NICKERSON, PROP.

Indiaxa Silo Co., Anderson, Ind.

Gentlemen:-Does a silo pay for itself in five months, taking November and December of 1908 and January, February and March of 1909? I discovered a vast difference from the same length of time of 1909 and 1910. Facts and figures show the following results:

November and December, $1909 \ldots \ldots \ldots \ldots \ldots \ldots \ldots \ldots \ldots . \ldots \ldots 5$

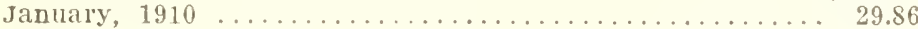

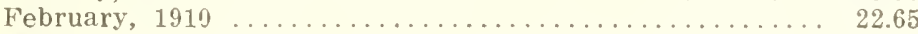

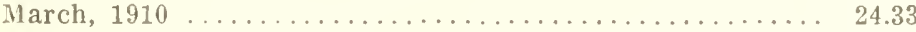

Total

$\$ 116.39$

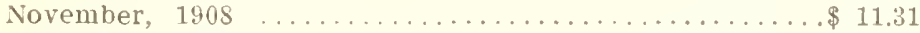

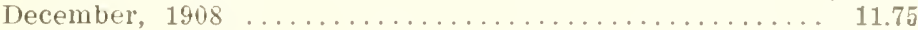

January and February, 1909................. 2.85

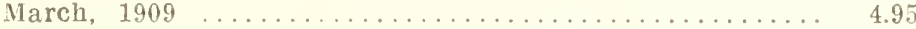

Total

$\$ 30.86$

Also $35 \mathrm{lbs}$, of butter fat was made at 30c pel 1b., in January, 1910, which

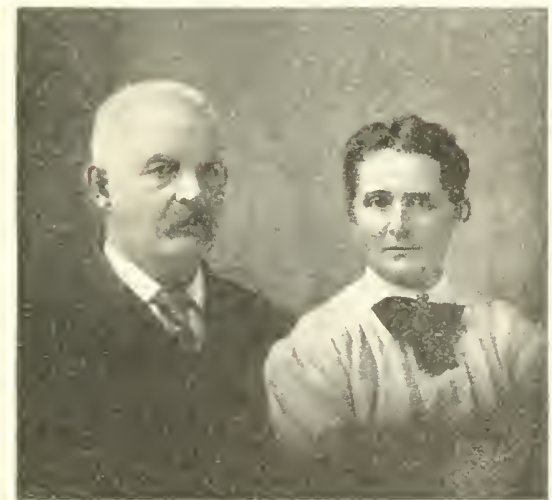

Mr. and Mrs. Milo Nickerson, Prairie du Chien, Wis. amounts to $\$ 10.50$, making a grand total of $\$ 126.89$ for 1909 and 1910 , against $\$ 30.86$ for 1908 and 1909 , a difference of $\$ 96.03$.

$\mathrm{Ninety-six}$ dol ars and three cents difference for a dairy of 6 cows with no other change than silage ration! Now there is just one item to be de. ducted from this amount- $\$ 22$ was paid out for a fat pig while the year before we fattened oll own pig, and a still larger item to be added. Seven tons of hay (worth on the market of Prairie du Chein today $\$ 12$ per ton, making $\$ 84$ less hay fed to the herrl for the five months just past, as compared with the same length of time a year ago.

I have a $12 \times 20$ silo with a rork basin four feet deep, making a $12 \times 24$. The rock is cemented. As we get down to the rock we find the silage spoiled about four inches wide all around next to the cement. They cost about $\$ 160.00$ complete, with a good shingle roof and a $4 \times 4$ flume attach ing the silo to the barn. I had corn enough to have filled this silo full, but the white grubs were very bad here last year, so we filled the silo just half full.

We fed two October calves and a yearling and some dry cows. makIng about \& head commencing to feed the silage November 14th. The calves spoken of are two which I bought. Our cows were all strippels or farrow, due to calve in April or May. With the old dry bay ration they 
would all have gone dry socner or later and we would just about supply our family with milk and butter, so we figure something like this:

Credit.

Hay saved $\$ 84.00$

Debit.

Milk, butter and cream sold over last year. 96.03

Charged to putting crop in silo instead of feeding corn

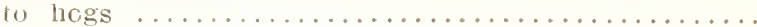

('ust of silo

Total

$\$ 180.03$

$\$ 182.00$

These ale lints which can be moven at any time. Yours truly,

MILO NICKERSON,

Prailie du Chien, Wis.

\section{BELIEVES SILO WILL LAST A LIFETIME.}

INHAdA SILO Co., ANIERSON, IND.

Gentlenen:- Some time ago I received a letter from you asking me to wrife vou about my silo I have been busy so put it off, but I hope to get a prize anyhum. I write to say to you personally that 1 am more than pleitsed with results.

(m) yeal ago l purchased an lndiana Silo, $18 x 36$, Yellow Pine, from youl seneral agent, and leel that l must write and tell you I am more than pleased with same. A silo is surely the business way of farming and there is absolut ly no better investment for a farmer to make than to put up a silo. It will bring more than 100 per cent. on the investment. I lalmerl (1ght years without a silo and feel as though these years were spent foolishly. I will hereby send some figures I have taken from my notebook, I am il dairyman and sell wholesale milk. I made milk without a silo as tollows:

November, 1908 , sold milk for...............\$287.50

December, 1908, sold nilk for.................. 343.08

Jamuary, 1909, sold milk lor................... 305.46

Bought dried lorewery grain, same three months averaged $\$ 110.70$ per month. I milkel 30 cows and each cow was given 12 lbs. corn meal daily, or 360 lbs. daily, which totals $10,800 \mathrm{lbs}$, per month.

This ycal 1 userl a silo and got following results:

November, 1909 , sold milk for...............\$273.00

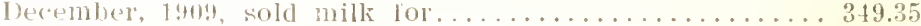

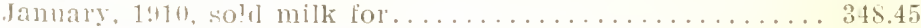

Dried brewery wain same three montlis averaged \$is.ss. I milked 25 cows and they wert givell daily fit lls, corn meal each, or $162 \frac{1}{2}$ lbs., totaling 4,875 ths. por month. If you figure silage lor 25 cows three months as neill as I ean figure, it amounts to about fi acres.

I saved leped hill

$\$ 155.46$

Rocelved more lor mills.

Saved coll meal dajly, $1971 / 2$ lbs, and milked ti cows less.

This is the result lrom three months and I think the silo will last as long as 1 need one. Yours truly,

ED. PETERSON,

Longview Farm, Lombard, Ill. 


\section{JACOB KUSTER, DEALER IN ALL SIZES OF HARD COAL.}

Irdiana Silo Co., Axdekson, IxD.

Gentlemen:-I built and filled my silo in the fall of 1905 and am glad to say I made enough money above otler years to pay for it the first year. First, by increasing my herd from 6 to 10 and since more, and the milk I received more than before; the saving of bran and feed of all kinds. My cows give milk as if on pasture and look glossy and nice. I had the first silo in my neighborhood and since a good many more were built. 1 would not like to be without a silo, as the silo puts my feed in best shape for the cows or any animal that chews a cud. It saves me a good bit in the way of grinding my grain. I would send you a photo of silo, but have it in the barn. I had exact figules of last year, but have mislaid them. Yours truly, JACOB KUSTER,

Selinsgrove, Pa.

\section{HOPES HIS EXPERIENCE MAY HELP.}

Indiana Silo Co., Andelsox, Ind.

Gentlemen:- Lmon lequest 1 am very glad to formald you infouma. tion as to what the Indiana Silo

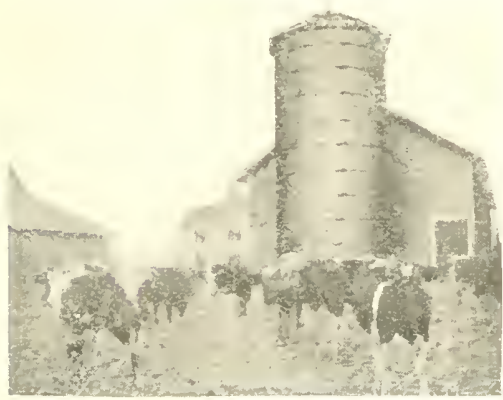

Charles Pickworth's Silo and Holstein Herd. has done for me and what it will do tol others.

I purchased one of your Indiana Silos of your agent, Wm. Weaver, foul years ago last fall. It is a 14foot by 30 -foot of good material and from all appearances it is as good as the day it was elected. This silo refulues fiom 6 to 9 acles of corn to fill it, according to the growth of the fodder.

I all now milking from 15 to 18 cows the year around and have since I purchased the silo. My dairy cows are mostly Holsteins and have a fine herd, the silo doing its part toward making them good lookers as well as good milkers. I sell at least $\$ 200.00$ worth more of hay every year since I got the silo than I did before. We winter from 15 to 20 head of cattle on the silo feed and feeding but iittle dry feed.

There are several of your silos in this locality and are all giving good satisfaction. I would advise all winter milkers to purchase one of the best silos, which would be an Indiana. Any one wishing to buy a silo would be wise to consult an owner of an Indiana first and I am sure he would feel convinced to buy one, especially if he should talk with me, as I cannot praise it too highly. In fact, I would not part with my silo for any amount of money providing I could not get another one like it.

I will also enclose a picture of my silo and barn with a few of the cows in case you should care to print it.

Hoping that this letter may prove beneficial to some one, I remain yours truly, CHAS.PICKIVORTH,

Wellington, O., R. F. D. No. 2. 
IndixA Silo Co., ANDerson, Ind.

Gentlemen:- As you have asked me to forward my experience with a silo l will endeavor to do so, but my experience is one of rare occurrence. My corn had almost reached matmrity when it was completely destroyed by hail. The blades were stripped from the stalks and the stalks broken off, having nothing but stalks with a few nubbins. The loss I cannot fully estimate, but as I had seen the results from a silo I concluded I would buy one.

I had a small dairy of 8 cows, so I bought a $10 \times 24$-ft. silo. It took 10 acres to fill it. Certainly there was never such material put into a silo for ensilage. Your agent, Mr. A. Seely, saw the field of corn and can verify my statement. I have first figmred what it would have cost me to have it cut and put in shocks and then have it shredded and put into the barn. Why I have mentioned shredding is because I would have had to have it shredded, for no man could husk it by hand and make living wages. It would have made abont 6 bustuels pel acre, in all about 60 bushels on the 11) acres. Following is what it wonld lave cost to put it in the barn, counting all expensts: Cutting 240 shocks at $6 \mathrm{c}, \$ 14.40$. It would have taken about $1 \frac{1}{2}$ days te shred the 240 shocks.

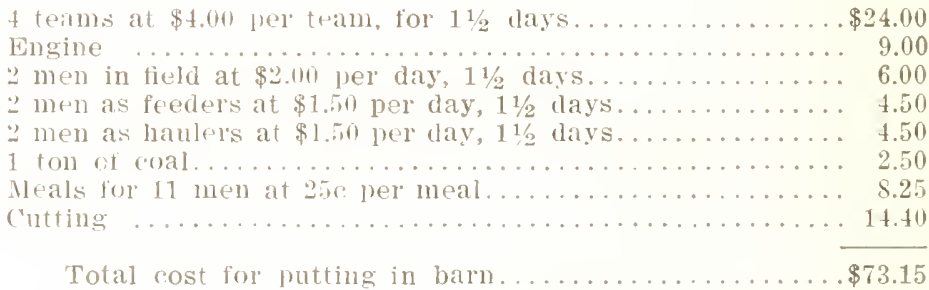

If I had not p'it it into a silo l would have had to buy 12 tons of hay extra. This would have cost me $\$ 12.00$ per ton besides hauling. Follow. ing is cost of luay and hanling:

Twelve tons of hay at $\$ 12.00$ per ton, $\$ 144.00 ; 1$ team and 1 man for help lor $t^{1}$, days, $\$ 20.2-$. connting team at $\$ 3.00$ per day and man at $\$ 1.50$. I would lutie had to buy 60 bushels of corn extra at soc, $\$ 48.00$, and hauling, \$3.00. Total expense had I not put into silo:

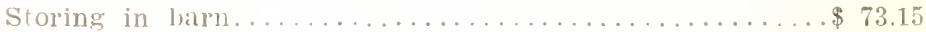

Hay and hauling........................ 164.25

Corn and luanling....................... 51.00

Total

$\$ 288.40$

following is expense of putting into silo:

Cost of silo complete, $\$ 129.60$; cost of filling, including machine, teams. men, coal and meals, was $\$ 30.25$; in all, $\$ 159.85$. Difference of expense, $\$ 128.55$ in favor of silo. Gain in flow of milk was $2 \frac{1}{2}$ gallons per day, and as I fed 16.5 days the gain was 412 gallons, retailing at $28 \mathrm{c}$ makes $\$ 115.36$, a profit in all of $\$ 243.91$ for the silo.

Taking all in consideration, I do not think it conld be beat. Let us take our hats off to the silo!

P. S.-This was in the fall of 1908 .

CHAS. PLANCK, Camp Chase, Ohlo. 
INDIANA Silo Co., ANDElisox, INT.

Gentlemen:- The tollowing is a true statement as to what I think and what I have done with the silo:

I put up my silo last fall, a $10 \times 26$, holding 43 tons, had 12 acres rented corn on the farm and put half in the silo, which lacked two feet of filling it. The corn failed to ear good. The other half was shredded, making 125 bushels. I took one load out for my hogs before I filled the silo, making about 100 bushels of corn in it. I commenced feeding out of it November sth. Have wintered 13 last spring's calves and 3 milk cows, 13 sheep, some chicliens and have enough feed until May 1st. I had no other feed except some straw. My sheep are fat and calves look better than the average in my neighborhood.

I am sure my silo has paid for itself already. Yours truly,

H. A. SHERRILI,

Cloverdale, Ind.

\section{$33{ }^{\prime} 3$ PER CENT INCREASE IN MILK FLOW.}

INDIANA Silo Co., ANDElsox, IND.

Gentlemen:- It is to my certain knowledge a fact that a modern upto-date silo fsuch a one as is put out lyy the Indiana Silo Co., of Anderson, Ind.) is the very best possible investment that a dairyman can make, and the sooner he realizes this the better off he will be.

1 have a gool farm of l:32 acres and have been in the milk producing business tor en years. I keep 5y cows and 1 bull. About two years ago I bought two lndiana Silos, one dixil leet, the other lixge feet. These

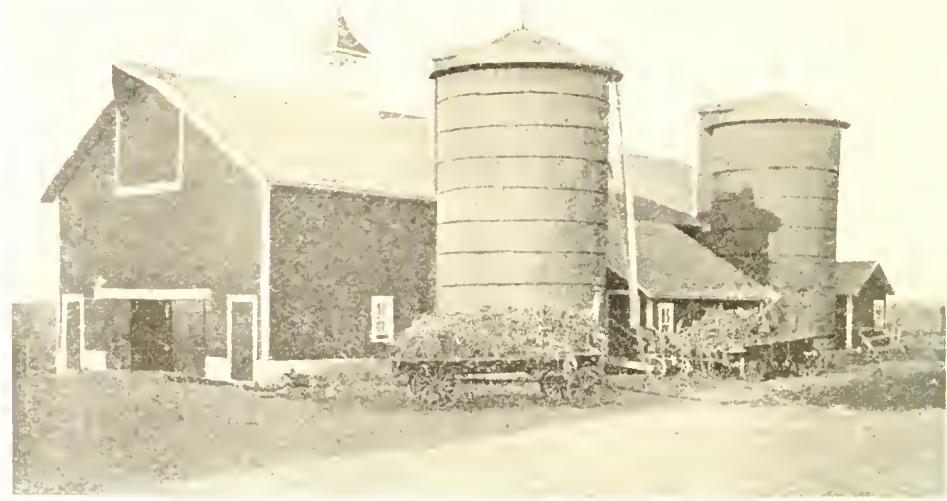

Frank Pratt's Silos and Barn, Wayne, III.

silos more thin paid for themeelves the first year. I do not now use more than one-half the amount of gromel fered I did before 1 had the silos, and my labor expense item has been cut in two by their use.

A farmel nsing silape is always able to have clear ground, as the corn shocks an be lemored immediately, llus allowing them no opportruty to detwiolate by exposire to the we:thel', and the wround is always ready to plow when the froper tims comes.

One are of silage fodder l lave fommd will go just as far as twice the atcreage of dric fodrler. 
Silage makes the most desirable feed I liave yet seen for cattle, and has the advantage of keeping the cows in fine physical condition all year, and in dry weather the feeding of silage keeps the flow of milk practically uniform and continuous.

Last year the milk from my 59 cows netted me $\$ 105.00$ each for the year, which is an actual increase per cow since the use of the Indiana Silo on my farm of $331-3$ per cent.

Any way l look at it, I camnot help but see that the use of silos has been extremely profitable to me. Their use cuts my labor expense about in half, as the actual requisite labor is reduced fully so per cent. It only requires one-half the lormer amount of acreage for fodder, and l have $331-3$ per cent. more milk to sell.

Following 1 give a table showing my milk shipments for last year, as rendered by the creamery, which I consider a very fair showing, and one only made possible by the use of the silo:

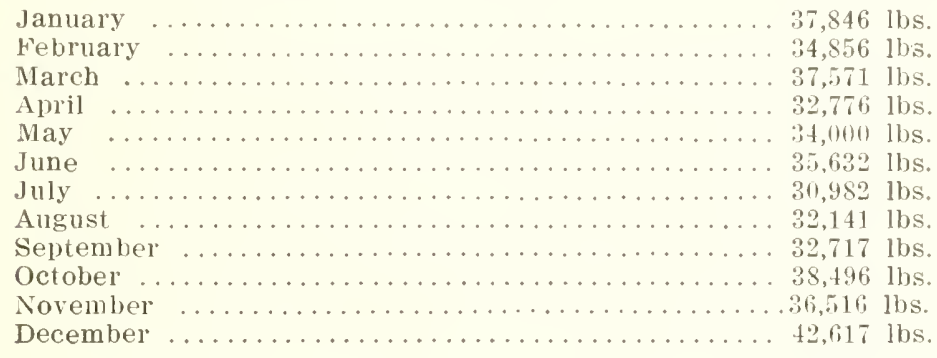

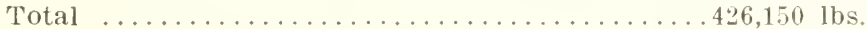

Average per month.................

I think that the invention and use of modern silos is the greatest step forward that has ever been made in the milk producing industry.

F. B. PRATT,

Wayne, Ill.

\section{BUTCHER LIKES SILAGE FED CATTLE.}

Indiana Silo Co., Anderson, InD.

Gentlemen:- In regard to the profits in dollar's and cents I am not ab:e to state, as I always fed ensilage in connection with other feed, clover hay and corn fodler and oats straw.

I will say I have produced splendid butcher stuff made from ensilage, clover hay and not any corn except what was in the ensilage. I sold a city butcher one spring in the month of April, 9 head at a fancy price and he was skeptical as to their fat and how they would hutcher out. So he asked the privilege of butchering one and if it did not show fat on the inside as they looked, he wasn't to take any more of the heifers. So I told him alright. So be commenced to butcher them. He took them all and when he was opening the last one I happened where thev butchered in the field. He stated to me: "Do you know what I would do if I owned a farm?" "What would it be?" I said. He stated, "I would build a silo." So I conclude by saying that any farmer in the corn belt on high-priced land that handles young cattle can not afford to do without a silo. Yours truly,

SMITH REMSTER, Veedersburg, Ind. 
Indixa Sllo Co., Axdersox, Ind.

Gentlemen:- Some actual facts in regard to economy and usefulness of the silo as I have taken from my own observation in feeding silage.

First. Buy a silo from some reliable company, air-tight, round, not squale, for the leed will not keep good in a square silo.

second. Hare some experienced man to erect your silo. If it is worth loins, it is worth doing light.

last fall $\mathrm{I}$ put $1 \mathrm{~s}$ acres of corn in my two silos, $12 \times 24$ and $14 \times 24$. The oorn would have sold for $\$ 7.00$ ol $\$ \$ .00$ per acre in the field; was not rely gool. I rould not attend it on account of the wet weather. I am foreling cows by the month for another party and the cows have a straw stark to lun to. I an not leeding anything else and am keeping the cows to the entire satisfiction of the owner.

The silage foom that 1 acress will bring $\$ 800.00$. If anybody would doubt these figmes 1 would sinow them the arcounts as I have kejt them by the month, besides having the silos. I can keep a nuch larger number of sock than I could without the silos. I am making a world of manure rrom my straw stack, which I consider very valuable to my farm.

At the rusent time it is the feerl proposition that is staring the farmer in the race. Buy a silo and you have the problem solved for all time to come. Sincerely yours, JOHN RAUTON,

Camby, Ind.

\section{SUMS IT UP IN A STRIKING WAY.}

INDIANA Silo Co., Axderson, Ind.

Gentlemen:- Fom letter at hand and wish to say while I cannot give any exact figures as to results I do know that on a 60 -acre farm with about 25 acres of it too rougli to farm and not good pasture. I kept on an arerage of 2 li liead of horsis and cows, mostly 10 head of cows and balance young heiftrs, and a few hogs.

1 hat a $10 \times 30$ silo (Indiana), filled it with (lover, which fed my cows till corn cutting time, when it was filled with good mature corn, which fed them until clover came again. We sold milk at from $\$ 90.00$ to $\$ 130.00$ per month and sold hay to more than balance all the mill feed we bought. The last two seasons we harvested 50 to 45 tons of hay respectively, not comnting what we put in the silo. We made manure enough to covel' rrom 15 to 18 acres each year for the last three years.

Fire years ago 1 hought this farm for $\$ 1,000.00$ and it was said to be the porest farm in the township. I sold this farm in October, 1909, for \$10,70(1) (10. Now what sold the farm? Feeding about three times the lusual amount of stock with the aid of an Indiana Silo, said silo being in as good contition today as the day it was put ul).

l.ast fall I wrote you in legard to another silo for my other farm and the reason you did not hear from me was that I bought two Indiana Silos at a sale here, one $19 \times 30$ and one $12 \times 24$, hoth for $\$ 98.00$. (How is that for baroains?)

I have now 11:' acres in the home alm, have a basn $36 \mathrm{x} 5 \mathrm{~s}$, with basenellt stahling. Will erect both silos this spling. Am milking 10 head of cows now and selling on an arerage of abont 24 gallons per day, White if I had a silo I could double this twier ofer.

Will some time sent you a photo of my silos and barn.

l sum the thing w? this way: A silo, more cows; more cows, more manme; more manure, more corn and hay; mose corn and hay, more silos, and always the Indiana Yellow Pine Silos. Yours very truly,

JOHN IV, REIMER,

Arnold, Pa. 


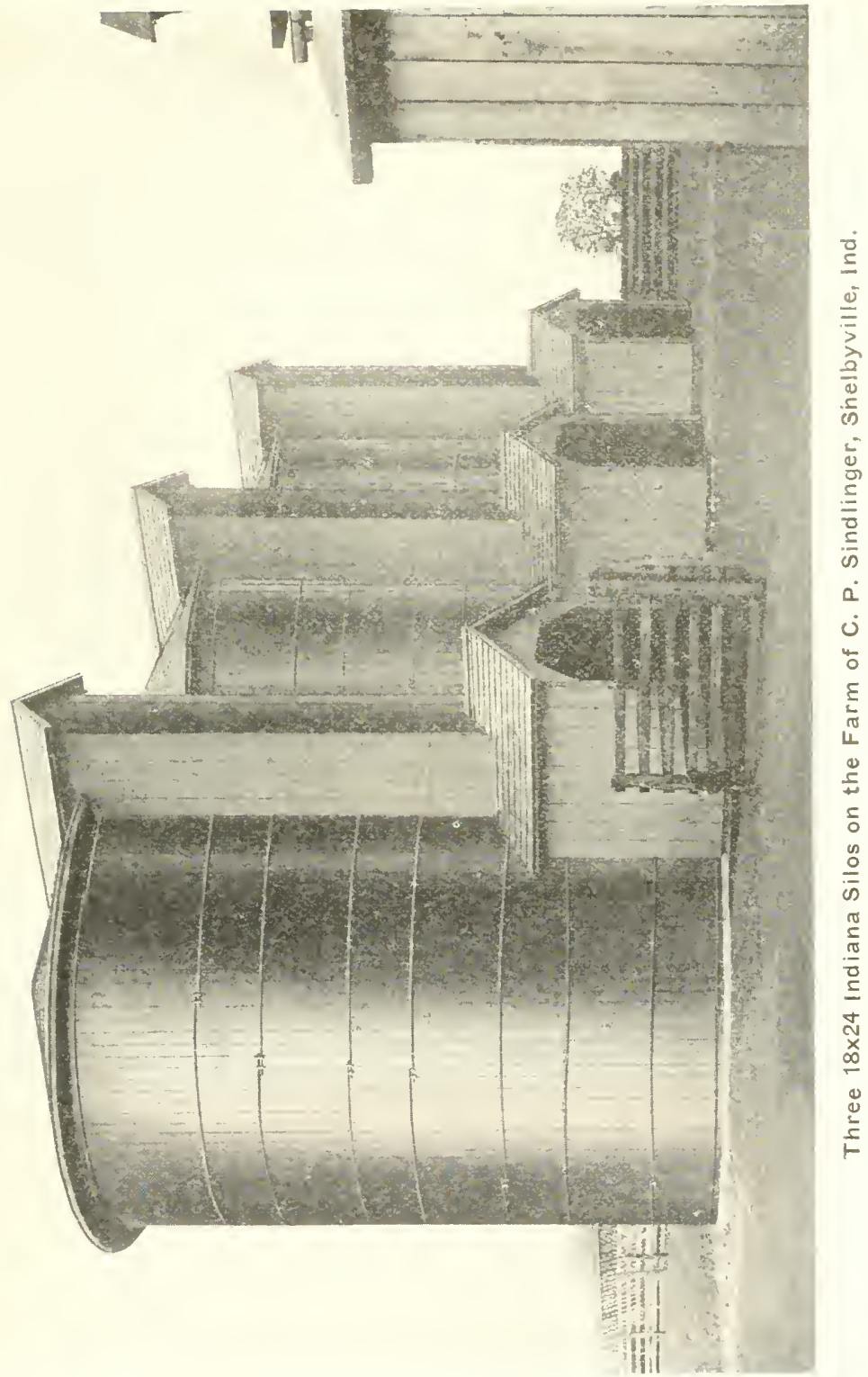


Iroiana Silo Co., ANDERson, Ind.

Gentlenen:-l have used silo feed for the last four years. The first year I bought only one of your silos as a test, and found it what I wanted. The following year I bought two more. I now have in use three of your 120-ton silos, $18 \times 24$, holding 360 tons of feed.

Two years ago I made a test of the silo feed on 110 head of steers, s-year-olds coming 3. They averaged $1,020 \mathrm{lbs}$. When started on this feed. l fed them five months and at the end of this time they averaged 1,435 lbs. and were in fine condition with a good finish. These cattle were fed 50 1Js. of silo feed and 1 peck of crushed corn (cob and grain) each day, with plenty of clovel hay. I found that while leeding the silo leed the cittle did not eat near as much hay as they did when leeding dry leeds; they would leave everything fol the silo feed. In this bunch of cattle I hild one stcel that I experimented on for my own special benefit. I selocted, as I thouglit, a steer that would make a good gain on a long feed, and started him on full silo feed and crushed corn on the 5 th day of hecember, 1908, and fed him until the 2and day of December, 1909. This ster weighed 1,230 1bs, on lecember sth, 1908, and on December 22nd, 1004, when he was slanghteled, he weighed 2,480 lbs. The first fire months he made an average gain of 5 lbs. pel day. This steer was not like most cattle that have been fed on a long feed-big lumpy fat stuck on him. His fat was nice and even thronghout the neat and well mixed. silo leed will produce both meat and lat and does not produce that big lumpy lat that you get from using other feed. This steer, dressed, netted (i.5 per cent. and I assure you was a great piece of meat. The 110 head of cattle mentioned above, fed by me, netted on the block 62 per cent. I cut every one of these cattle over the block and disposed of them through my meat store, in this city. I feel safe in saying that there was never a hunch of cattle of the same number, ted in any other manner, that equaled these cattle. These cattle cut just as firm and the meat was just as solid as any coln-fod cattle that I have ever slanghtered, and i have slaughtered thousinds of them.

I an now feeding 100 steers that will average about 1,275 lbs, and they are loing fine. The reason $I$ use silo feed is because it is the cheapest and best leed I can find, after having tried every kind of feed offered. 1 can lloduce more flesh and fat and place it on the cattle more evenly than with any fed I have ever used. I have had fifteen years' experience in this business and have averaged 100 cattle per year of my own feeding. My silo feed this year stands me $\$ 4.13$ per ton in the silo, and my silos were filled with corn that made 70 lushels to the acre. Silo feed is the best and cheapest on eartl. This is my experience with silos feed, and all these statements 1 can back up. Yours truly,

CIHAS. P. SINDI,INGER,

Shelbyville, Ind.

\section{CATTLE LEAVE PASTURE FOR SILAGE.}

Ixmaxi Sum Co., Axmensov, $1 \times 1$.

Gentlemen:- The silo I bought of you in Felruary, 1909, came all right. Every piece was all rinht, first class and fit perfectly, it being the sucond one bought in this part of the country. By the aid of a carpenter and my planning to crect withont saltuking, l placed a ladder on the inside, reaching dear to the top of silo, mittins rod through the top end of ladd.r. and legi s. we "nu'd move it around, and then placed one man 
on top of the ladder and one man in center on short ladder and one man on concrete, that is the bottom, and one man to place staves, and we soon erected it.

I filled it with 75 tons of sweet fodder after corn had been taken to canning factory. Began feeding December 1 st 12 head of cattle and $S$ head of horses. Sold one heifer the middle of March to butcher, fat and plump, and it is a milk producer. This heifer was fed no grain, nothing but silo ensilage. Mr. Macey at Union City was to see our silo and says that he has four men contracted for silos and there will be a number sold through this part. My cattle come to barn from pasture field at noon and we put then in the barn and feed silage. Horses will leave bright timothy hay lor silage. I can say this for the silo: A man that farms will not be a farmer unless he has a silo.

$$
\begin{aligned}
& \text { FRANKLIN P. SIPE, } \\
& \text { Union City, Ind. }
\end{aligned}
$$

\section{SUCCESS WITH STEERS.}

Indina Silo Co., Anderson, Ind.

Gentlemen:- The $16 \times 34$ Yellow Pine Silo we purchased of you last fall arrived in good shape and we found it easily set up. The purchasing of a silo we had been considering for a number of years. We hesitated on

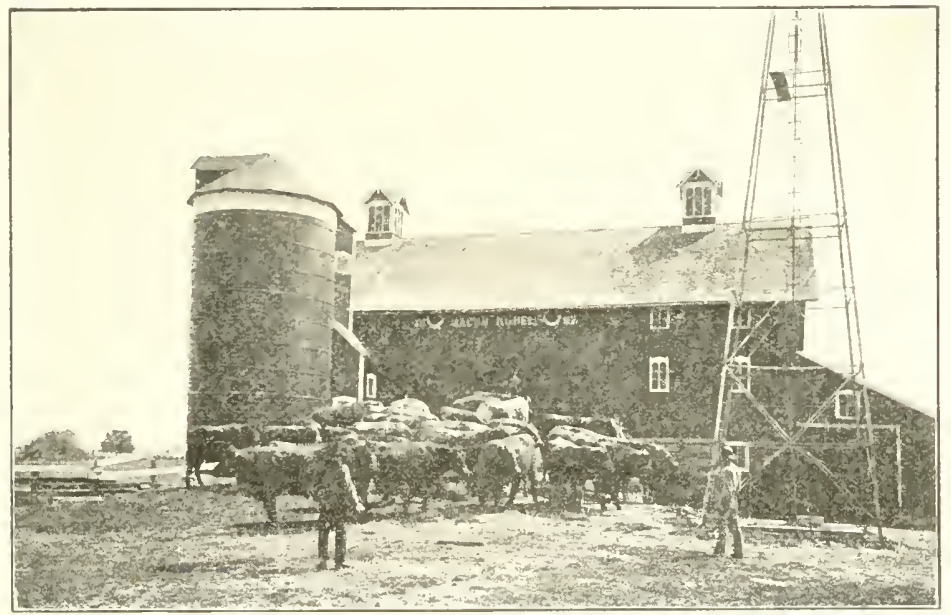

Jacob Rupel's Market Toppers.

making the pioneer start, but now see tle lallacy of hesitating. We filled our silo with 13 acres of corn when it was about ripe enough for the shock. In finishing filling we run about 30 barrels of water on tol. The waste was only about a manure sprealler load. We opened the silo on the 27 th and commenced feeding 35 steers, of which we send ficture. We have been feeding cattle more or less for 20 years. In 1904 we fed and show d the first-prize yearing of the Southwest District at Chicago and do not believe that we have ever had cattle do so well or make so economical gains. Yours truly,

JACOB RUPEI, \& SON,

Bryant, Ind. 
Iximix Silo Co., Axperisox, Ixu.

Dear sir:- - ln reply to yours of Mareh "̈rd, would say I bought a silo by much talking and persuasion in the fall of $140 \mathrm{~s}$ and filled it with ensilage or corn and then I bought 20 Kansas calves that mere so pool l was ashamed to have anyone see me divw them home. It was the 6 th day of December that 1 commenced to fecd them ensilage with a little hay. Along about the tirst of June they hal done so well and gained in flesh the butcher wanted to buy them fol heef. Besides feeding the calves I fer s head of milch cows, which gave more milk than they ever did before. Fted some to my bolses.

I bought the silo on one year's time. It cleared itself, as 1 consider, the next June and l paid for it. I consider it was the best investment I

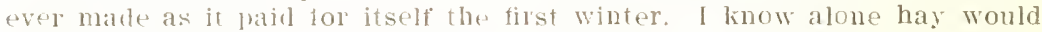
never have hrought those ralves ont in the same length of time. So much for the lirst winter.

(3) arecunt of the labing health of ny wife we left the farm in June and lented it for three years. I made a sale April 9th and then had 15 tons of ensilage in the silo, yet the r'ntel bought the ealves and ensilage of corn. Ile hat fed it all otit by the first of Jume. Now you can see if the silo mas a profit to me or not. I consider my silo paid for itself the first winter. 1f l never go on the farm again I consider I am ahead, but if I do I consiler the silo is the bust money making thing on the farm. Yours with best wisbes.

C. S. PAIEEN

San Diego, Cal.

\section{PLEASANT VIEW STOCK FARM.}

INTiAx silo Co., Axtersox, Ixw.

Gentlumen:- Three years ago I erected my first Indiana Silo, $14 \times 24$, and was so much pleased with the results that I mut up another one the following yal. Last fall somehow I thought I would not put one up, but gave the company my orler for a $12 \times 21$ to put up this fall, 1910 , but I am figuring to change it to a $16 \mathrm{x} 36$, so I will have most of my corn crop into silage, and have it ready to feed instead of bad weather overtaking it in shocks out in the field, as I have some at the present time, which juts me at least $\$ 300.00 \mathrm{in}$ the hole. There is nothing like a silo to take care of a coln crop. I feed silage to 38 head of pure bred Holsteins, feed about to $1 \mathrm{hs}$, to milch cows, and the young stuck according to age.

One of my cows, General Paul De Kols Marreta, No. 41204, when fresh, gives from tis to $7 t$ los. of milk for six or eight months, daily, and a number of others (lo as well. I feed about s lbs. of Hammond's dairy feed per head busios the silage, and when milking time comes it takes but a little while for t'- or 14 cows to fill six cans per day.

Whan I fut my first silo mp my noighbors snickered to themselves and said when they got hunery tor sanel klant they would come over. Since thri a latre mumbl of silos have gone up around here and I think I can help the Indiana Silo Co. to ulace a few more when silo time comes again. The le is nothing like an Incliana Silo for me with plenty of good silage in it to fred evel'y day in the year. It keeps your cattie slick all the way trom the old cow down to the yomg calves. My farm consists ol 95 acres. I keep 5 horses thal I feed silage three times instead of oats or coln and there is no one who has horses that look better than mine. Yours truly,

II. ' RATHMANN Hebron, Ind. 
Ixdiana Silo Co., Anderson, IND.

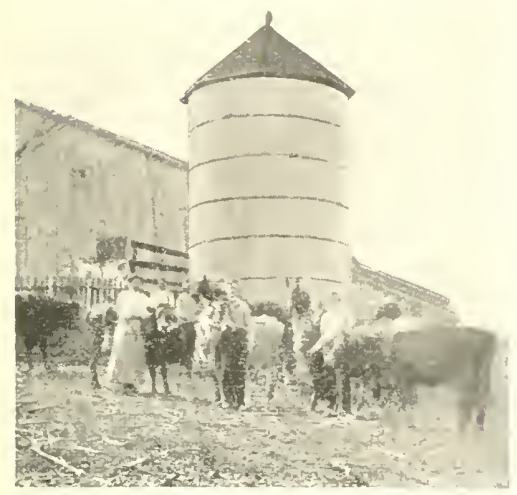

Henry Stallo's Silo and Part of His Family, Lexington Pike, Ky.
Gentlemen:--1 am mailing to day under separate cover a picture of my silo. I must say that it is one of the most needed articles for the dairyman. It is certainly a profit to every farmer. It has saved me in the three months that I fed ensilage, from $\$ 100.00$ to $\$ 125.00$, which is certainly a great saving to me. I must also admit that as soon as I quit feeding ensilage I received from 8 to 10 lbs. a week less butter.

Hoping that your business will be very prosperous and that you will be able to convince every farmer in the United States of the great profit-sharing silos, I remain yours, very truly,

HENRY STALLO, Lexington Pike, Iy

\section{COWS FAT AND HEALTHY.}

Indiana Silo Co., Anderson, Ind.

Gentlemen:- Last year your agent came to my farm and tried to sell me a silo. At first I was not much interested in it, but he talked so long that I bought one.

It was one of your medium size ones, $12 \times 28$. The silo came about the first of May and I was very much satisfied in the shape it came, not a stave was cracked. I set it up the 15 th of September and everything went O. K. Ou neighbor's never saw such a durable, strong, air-tight silo in their lives. I have seen many silos myself and took careful notice to their doors. All of them had $1 \frac{1}{2}$ inch doors, and were very light in weight. My silo has 2-inch doors perfectly air-tight and perfect fit. I filled my silo about the first of October.

Your book tells us that a silo $12 \times 28$ takes 8 acres of corn, but I sowed only 6 acres and I filled it twice, and when I was through I had one-halt acre left. I started to feed the 20 th of November, 18 milch cows twice a day. Only a little of it was spoiled on top. I will have enough until May 20th, making 6 months in all.

Now here are some of the profits of getting the silo: Each month the milk averaged $\$ 7.50$ more than without a silo In six months it would be six times $\$ 7.50$, which equals $\$ 45.00$ in milk only. Eight tons of hay were sold at $\$ 15.00$ per ton, equaling $\$ 120.00$ more than other years. In all the protits were $\$ 120.00$ and $\$ 45.00$, equals $\$ 165.00$. I paid $\$ 150.00$ for the silo, which leaves me $\$ 15.00$. Fifteen dollars and the silo in one year. I cannot praise the silo enough. Sonetimes I think about buying another. Now another thing: Look at my cows-they are fat and healthy. The butcher can come now and pick any one out and it is ready for market. Othel years they would look like broomsticks. best.

This is all I will say about the silo, but I like the Indiana Silo the JOHN SCHUITEMA, Hudsonville, Mich. 


\section{Indiana Silo Co., Axperson, Ind.}

Gentlemen:- In the year 1889 we were persuaded to put up a silo to furnish ensilage for our dairy herd that had formerly been fed on dry lodder and husked stover.

This silo was a stave silo made from $2 \times 6$ White Pine staves, neither beveled, tongued nor grooved, but hooped with Ts-inch iron hoops, which drew ul tight when nilled, and gave us good ensilage. In 1901 we bought a Kalamazoo stave silo of the Williams Mfg. Co. This was still an improvement over our first silo. In $190 \mathrm{~s}$ we felt the need of more silo room, when, alter examining several of the best makes of silos, we bought two $16 \times 30$-toot Gulf Cypress Indiana Silos, which were promptly shipped and reached us in good condition. Our carpenter, who had never put up a. si o, with the aid of two green men, pue these silos up in two days. The bill was all complete, not a stave, hoop, lug or burr was missing, and ev'lything went together easy and right, quite different from other makes of silos that arrive with something gone in most every case. The latter palt of Seftember we filled these silos with Eureka ensilage corn. In December we began feeding from these Indiana Silos. We found this ensilage the best kept ensilage we ever fed. About May 15, 1909, we quit feeding ensilage mntil August 10th, when on account of hot weather, poor pasture and swarms ol flies, our cows were shrinking on their milk flow so badly that we turned to our Indiana Silo for relief, and found only a very small anount had spoiled as the silo had remained tight right through the hot, dry weather of simmer.

We bogan feeding ensilage again, when inside of 10 days, our cows had gained an average of $s$ los. of milk for each cow per day, which, at $11 \%$ per 1b., made an average gain of $12 \mathrm{c}$ per cow per day, which, with a herd of 30 cows, would soon pay for an Indiana Sito.

We recommend the Indiana silo for the complany is composed of straight, honest, mpright men, who do just as they agree. The workmanship is superior to all other makes of silos. The splice is the best ever invented. The don frames are strong and mike a continuous opening. The dowrs do not stick like doors of other makes of silos. The door fasteners are rey simple and make the best kind of a ladder to go up and down on.

We are very glad to indorse the Indiana Silo and recommend the comprany, who have made it possible for the dairymen of this land to secure so mood a silo for so Jittle money as the Indiana Silo.

F. W. PIERCE, OF KNAPP \& PIERCE,

East Claridon, Ohio.

\section{PERFECTLY SATISFIED.}

Inima Silo Co., Annerson, Ind.

fientlemen:-Received your letter O.K. Was very glad to hear from ynu.

I will recommend the silo to every farmer living in a corn growing state. If I had not liad the silage my cattle would have starved for I ran short of leed. I did not got all of my corn husked last fall and was short of hay. I would not be withont the silo or silage for ever so much if I could not get another.

I have three important reasons: Filst, because there is a saving in feeding of silage as overy part of the corn is eaten; whereas, with the very best corn fodder, no matter how fine and green the stalks may be, a considerable portion is wasted. Second, silage is cooling to the diges- 
tive system just like grass is. It keeps the physical condition of the cow In perfect order, while at the same time it stimulates the milk producing organs to the utmost. Third, it keeps the young stock in good condition. Silage is much more handy to feed than to be bothered with corn stalks. It also is worth more for manure, because the manure can be hauled out on the land the same spring. By feeding corn stalks they have to lay a year or more before it is worth anything.

Words cannot be spoken too highly for the silo. I am perfectly satisfied with mine.

I enclose a picture of myself with one of my young stock. I am yours truly,

CHRIS PETERSON,

Gilbert Station, Iowa.

\section{NET GAIN \$189.72 IN FIVE MONTHS.}

\section{Indiaxi Silo Co., Anderson, Ind.}

Gentemen:- I have your letter of recent date asking me to give my ideas and figures on results of the use of the Indiana Silo. I will try and tell you what I think of the use and give a few figures. I have a small nerd of Jersey cows-20 to 25 head in all. I usually milk 18 to 20 . Before I bought a silo I fed in winter for roughness shredded fodder and clover hay and cane and I fed bran and shorts mixed with about one-fourth to one-third crushed corn. I also fed cotton seed meal. I have a good warm barn and take good care of my cows and feed liberally. I did not weigh the hay or fodder for each cow, but fed all I thought they should have of each kind of feed. I kept a correct account of each month's milk checks.

I bought a silo and filled it in September, 1908. It is $16 \times 20,4$ feet in the ground, making it $16 \times 24$. I began feeding silage about November 15 . I had fed cane and Stowell's evergreen sweet corn in latter part of summer and fall up to November 15th. I began on ensilage and filled my barn with shredded fodder. I bought a ton of bran and a ton of cotton seed meal and began a light feed with about the same number of cows that I had the previous winter before I built the silo. I gave what I thought a good feed of ensilage with a small measure of cotton seed meal and bran and fed shredded fodder for roughness and my books will show the gain in dollars and cents per month for the winter months.

December my check gained..................\$28.50

January my check gained..................... 31.57

February my check gained ................... 37.68

March my check gained..................... 45.25

April my check gained...................... 46.72

For the five months I had a net gain of $\$ 189.72$ to my credit more than the same five months the winter before, and in April my cows came out in fine shape with more flesh, good slick coats and licking themselves. My spring and summer checks were still satisfactory as the cows went on grass in better fix han I ever had them when I fed the grain, brain, hay and cotton seed meal. I am well pleased with my silo. My profits from my herd the first winter paid for my silo and building it, and now I am in a hard winter with about the same herd, but not milking quite so many, and my silage makes me even better galns this fall and winter thus far than last year.

Hoping this little statement will be of service to you and other dairy farmers, I remain, respectfully,

SAM SULLIVAN, Bloomfield, Ky. 


\section{SILO AMOUNTED TO NET GAIN OF \$35 PER ACRE.}

Ininaxa Silo Co., Andersox, Ind.

Gentlemen:- I have been a user of the silo for twelve years and now

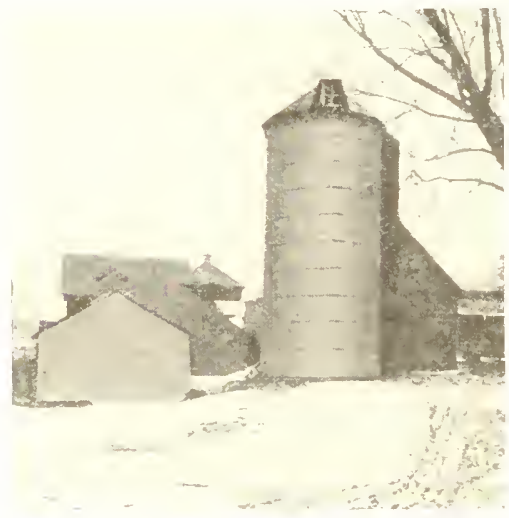

Barns and Silo of Geo. A. St. Clair, Vinton, la. have two on my farm. At the time I built my first silo I was running a dairy of 25 cows. The milk was weighed every night and morning and recorded to each cow. I find by looking over the old book that the gain was about one-third from the use of silage and that the expense of feeding cows dry feed was cut down about one-half.

I have also used it extensively on feeding cattle for market. I bought 22 head of steers last November that weighed 705 lbs. when put on feed. They were fed about 40 lbs. of silage daily, 2 lbs. of cotton seed meal and 10 lbs of corn. They were shipped in the first week of March. They weighid in ('hicago 905 lbs. and brought $\$ 6.60$ a cwt. They cost at the time of beginning to feed \$4.25. I find that after taking out the market price of the corn and what little hay the cattle got, thity gave $11 \mathrm{~s}$ about $\$ 5.00$ a ton for the en silage consumed, and as the corn that was put in the silo made about 13 tons, gain is \$6.i.00 per acre for every acre put up. This corn, if husked and sold, would have made about 60 bushels and been worth on the market $50 \mathrm{c}$, which makes a net gain for the silo of $\$ 35.00$ per acre, and I figure that the benefit the hogs received from following the cattle will pay for the labor of feeding it.

I do not sew how any farmer atu wo without the silo as it is a great saver of feed and a good terel that otherwise would be lost. Yours truly, GEORGE A. ST. CI,AIR,

Vinton, Ja.

\section{DIDN'T GET HALF AS MUCH MILK.}

Indiana Silo Co., Anderson, IND.

G-ntlemen:- I leceived your letter yesterday anı was very glad to read it.

Well, we have an Indiana Silo and we are very well pleased with it. Our silo is $14 \times 20$ and 5 feet in the ground and we fillel it up twice with corn last fall. We are feerling 14 head of cattle and we never bad so much mills as we have now. We have had the silo three rears already. Before we had the silo we didn't have half of the milk we have now, and we have been lianling milk all year' 'round and haven't stopped yet.

Last year l sold three of rour silos around the neighborhood and there are lour farmers in a row from here and they all have Indiana Silos, and many other lamers came here to see our silo and they thought it was better for the cows than the other feed.

Please send me some of your price lists. I have been selling silos foi your agent, John Rotbmund.

I thank you very much for the letter you sent me and I would like to get a plize. Yours truly,

IVM. SCHULTZ, Stangelville, Wis 
Indina Silo Co., Anderson, Ind.

Gentlemen:-During the summer of 1908 we erected one or your silos, $20 \times 34$, the first ever built within four miles of our station with the exception of one. During the following winter it furnished sufficient ensilage for fifty-five (55) cows 200 days. The amount of milk we delivered to the Huntley Dairy Co. during that period was so greatly in excess over the amount delivered by our neighbors from the same num. ber of cows that they came in numbers to learn the character of feed we were using. The result of this investigation was the occasion of over 20 silos being built during the summer of 1909 within sight of our farm.

The satisfactory results we obtained prompted us to build two addi-

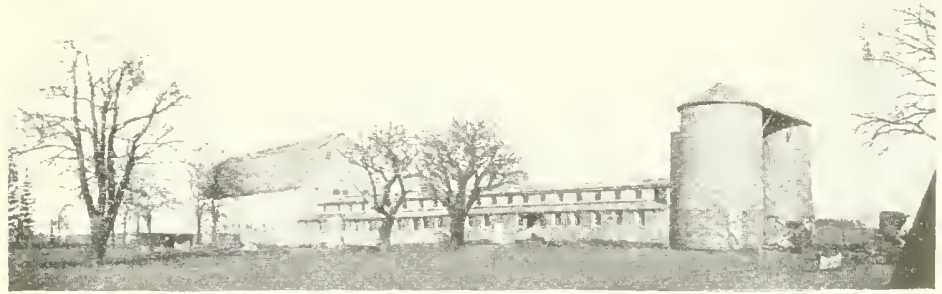

Oak Glen Dairy Farm, Frank G. Stevens, Supt., Bartlett, III.

tional Indiana Silos, the same size as shown last year, after our superintendent, who is a skilled mechanic, had made a careful investigation of the rerits of the various silos, the best of which were oflered at lower than 20 pel cent lower price than asked by your company, we decided it was the line of our best interests to build the track additisual inside our silos, our reason being better door frames and door construction, coupled with the fact that yours was the only one with the tongue and groove end to staves, which preveuts rotting where joints are made. The value of ensilage as food for live stock and economy as compared with other feed has ben so thoroughly proven by the Agricultural departments of the various states that in our judgment no farm where hogs, cattle or poultry are fed is complete without it, even though not interested in the dairy business. Yours truly,

S. P. STEVENS,

Bartlett, Ill.

\section{FINE FOR CHICKENS AND HOGS.}

Indiana Silo Co., ANderson, Ind.

Gentlemen:-We wish to say that we are more than pleased with our silo and cannot do without it. It has proven to be a great success. I think there is no feed like silage. It is always ready and handy to feed and the cows like it fine.

If you feed the silage a month you can see a grand improvement and in the spring they look like they have been running on grass. They don't laave long shaggy hair on them. It is an excellent feed for them and it is, also, fine for chickens and hogs. I do not see how any up-to-date farmer who has sheep and cattle can do without a sio and feed at a profit. I remain, as ever, your friend, 


\section{A FEW HINTS ON THE PROFIT OF A SILO.}

INDJANA Silo Co., ANDERSON, IND.

Gentlemen: - In my three years' experience of feeding silage, can say It has saved me 30 per cent. on my expenses over the old way of feeding, as corn stalks when cut and put in the silo at the proper time, make just as good feed as hay and aid sreatly to the hulk of the feed, which, when cut and dried, does not make any feed at all and not very much manure, but when cut makes an abundance of excellent feed. It is easy to raise 1011 tons on from \& to 10 atres and this makes another gain, as on average land it is true that from one to two tons per acre of hay is all that can be raised. maling a diflerence of from 8 to 9 tons per acre.

This shows plainly that a farmer can keep mores stock to the acre and add a larger quantity of good plant food to bis farm. Another gain in feeling silage is that it requir's only half as much high protein feed, such as mill feed, oil meal and gluten and I consider in this way my silos have savel me 30 per cent. on every dollar invested each year, which makes $\$ 70.80$ each, and for three years it would make a saving of $\$ 212.40$ ovel the old way of feeding. Besides this my coln is gathered earlier and much cheaper than one can gather it by hand and shred the fodder and the tifen is rmpty and leady to seed if one desires to do so.

\section{S. E. SHAFER,}

\section{Elkhart, Ind.}

\section{DOESN'T KNOW WHERE TO STOP.}

Indiana Silo Co., ANDERson, IND.

Gentlemen:- I received your letter a few days ago, but was moving and did not take time to answer. Don't know whether I can write whell you want to know, but will write a little any way. If it is of any benetit to you you are welcome to it.

I think that the silo is one of the greatest improvements, in build ings or machinery on a farm for economical feeding, and preserving feed. It does away with the feed grinding bill, and also of the high priced bran bill when you are leeding milch cows. It will not take more than half the hay with the silage as it will without it. The cows will give more milk and do better on silage than any other feed. They never get tired of it and if you don't have good pasture when you quit feeding it in the Spring the cows will fail in the flow of milk. A silo, also, enables a man to keen twice the amomnt of stock that he could otherwise. It is just as good feed for horses as cattle. They eat and relish it. They will eat all but the cob. The sheep do well on it. of course, you have to be careful in the start that they do not get stalled on jt. It is good feed for all stock that is raised on a farm, even to the laying hen. It comes the nearest being a balanced ration, and the cheapest and easiest for the farmer or stockman to feed, and at al: seasons in the year. When I hought mine they claimed that one in the dairy business needed one and some people claim they do not nerd one unless they have a lot of milch cows. This is alright, but I say that every farmer who has twenty acres or more needs a silo. The time is not long distant until they all have to buy them. They must feed their gromuds if they raise good crops, and this can be done best through the silo. The round silo bas come to stay and I would not advise any one to buy any other kind but a round silo, and no kind of wood but the best. I like the fir wood silo the hest. Yours respectfully, (UNSIGNED).

Kokomo, Ind.

P. S.-There is so much to say concerning the silo and its use and benefits derived from it I don't know where to stop. 
Indiana Silo Co., Anderson, Ind.

Gentlemen:- I received the silo all $O$. K. and it went together without any trouble,everything fitting nicely. I got my silo filled in good time, as it comes the time of year farmers are not busy. I began to feed Oct. 24 th, feeding 16 cattle, 3 horses and some to hogs and chickens. They all relish it.

During the entire winter I have only fed 5 tons of hay as my cows won't eat much hay with silage. During the month of March I made a net profit of $\$ 111.41$ from 12 cows. As this is my first year with a silo I do not know exactly the profit the silo has made for me, but the profit I have made from my cows is more than twice what my neighbors have made from their cows. They have no silos, so I think a silo will nearly pay for itself in one year. I am still feeding silage and will have enough to feed through May. My cows are on pasture, but they still clean up their silage.

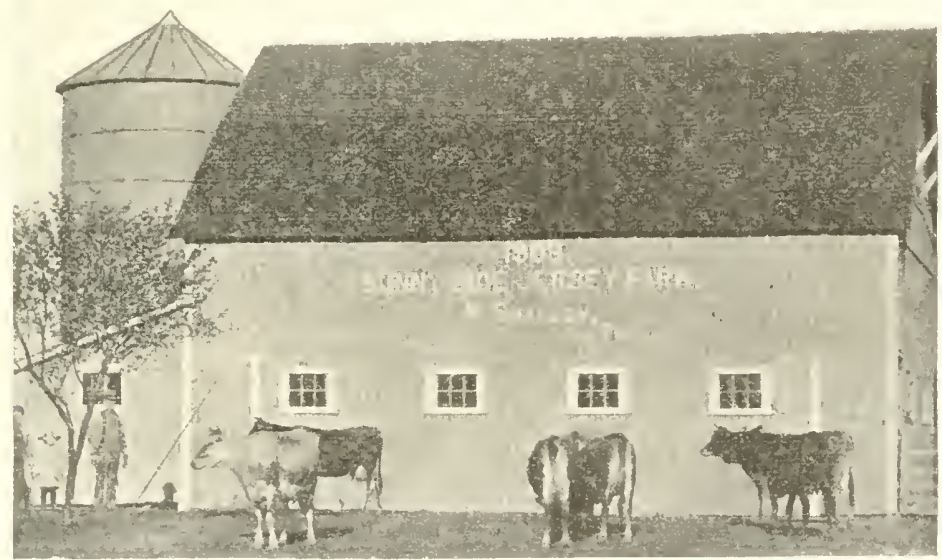

Some of Mr. Smalley's Good Jerseys.

I think I will buy another Indiana Silo this year to feed through the summer as it is cheaper than pasture and you get better results from your cows.

There are quite a few of my neighbors that have already bought Indiana Silos here and I only hope for mole to buy. I think the silo the best investment I have ever made. Very truly,

WESLEY SMALLEY,

R. F. D. No. 12, Cicero, Ind.

I am enclosing photo of barn, silo and also a few cows.

\section{ENSILAGE THE BEST ALL AROUND FEED.}

Indiana Silo Co.s Anderson, Ind.

Gentlemen:- It is useless for me to try to determine the value of sllo for cows. I have two 100-ton Indiana silos and wish I had as many more. I am milking about 50 cows and feed several heifers and calves besides I consider one of the first things essential is to get the silo filled 
properly by using a first-class machine and at the right season of the year. Then I assure you that the use of this fine leed will determine the results for itselt. In every case where cows have been deprived of a tew feeds they show a ravenous appetite for this feed.

Flom the stable to the table one has to guard against articles that would contaminate milk, for we find our greatest nourishment in pure, wholesome milk.

The leading dairy papers and speakers on dairy subjects are constantly 11 'ging the value of the silo upon farmers and that a strict milk recold kept trom every herd would bring unexpected results. No doubt if each day we were promptly intormed as to the condition of each cow we would find in the course of a year a considerable change in our dairy herd. These recolds are of great value in changing food rations to suit the individual cow.

The tarner is a close observer, an intelligent man, good disposition and of course is susceptible to infiuence by what he reads, hears and more or less by what his fellow neighbors do and say and how they profit by experience. What he looks for is more modern ideas and the best production with the least trouble. When the corn crop is a failure a small acreage will proluce more good winter feed in a silo than any other possible way. But in these times of prosperity we realize land is becom. ing too valuable for pasture-then what could be more valuable than a silo?

In summing up the silo it is a settled fact that there is no better all 'round feed, and I lon't believe it has ever been condemned by a farmer that knows what good feed it is. I think the sooner every dairyman puts up a good silo he will find collars where dimes have been.

\section{R. F. SHACKLEFORD,}

Briglitwood Station, Indianapolis, Ind.

\section{WEIGHS EACH COWS MILK.}

I:1,111. S110 Cu, ANDERon, IND.

Gentlemell:-In response to your prize contest offer I will give you my figures the best I can as to the advantages of the silo.

In the winter of 1908-09 I thought I was very fortunate in baving a barn full of the very best clover hay, also a large stack besides and an alumfance of corn stalks of the very best quaiity, but I had no silo thell. The ration for my dairy was all the clover bay they would eat ui) clian morning and evening and cornstalks at noon and twelve pounds of grain a day in two leeds. My average yield of milk per cow ver day was fourteen quarts

I bought an Indiana Silo in the summer of 1909 and filled it in Sep. temlur with well eared corn and began the last of September to feed it to the same cows I had the year before, and as I have a milk route I migh each cow's milk so I know just what they are doing. The cows that were giring only 14 quarts ner day the year before on the above mentioned ration have been giving 19 qualts per day this last winter, Even now, on the ensilage and on an 8 lb. grain ration per day with a very little hay in the morning, witl dry stalks at noon and no hay at night, they show a gain of 5 quals of milk per day per cow at my retail prike of tic per quil't or $30 \mathrm{c}$ ner cow a day, and a saving of 7.2c per cow on grain a day, to say nothing of the amount of hay saved.

I claim by the time it is empty about June 1 st the silo will be nearly is not quite paid for, and have a good new silo left for a good many years

RALPH P SHERMAN.

South Haven, Mich., March 31, 1910 


\section{THE ONLY FEED FOR MILCH COWS.}

Indiana Silo Co., Anderson, Ind.

Gentlemen:--In : gard to your letter 1 will say ihat I must talk in favor of the silo for it is the only feed for milch cows. It has saved me two-thirds of my mill feed as I used to feed 4 tons per month but this winter I only feed $1 \frac{1}{2}$ tons per month and get mole milk than I did when I fed 4 tons.

Now I believe when Sam Ellerman comes around that I can tell him where he can sell four or five silos for I have told them where they were losing money by not having a silo and they think $\mathrm{I}$ am about right in my opinion. I told them to come and see for themselves. My cows are fat and slick and look fine. truly,

Now I will close wishing you success in the future. Yours very STEVE N. SHORTEN.

Delaware, Ind.

\section{COWS EAT EIG FEED OF ENSILAGE ON PASTURE.}

Injiana Silo Co., Anderson, Ind.

Gentlemen:-As per your request, will try to write you of my success with the silo bought from you.

Before buying my first silo I had been feeding my cows corn fodder, crushed corn, bran, cotton seed meal, linseed meal, etc. It took about all I could get out of milk to pay the feed bill, so that made me begin to study. I was a little afraid to try the silo. Some of my neighbors had tried them and failed. I was reading some good dairy papers and they convinced me that the thing I needed most in my business was a silo. I wrote to nearly all the silo firms I could see advertised and concluded that you had the best and cheapest silo on the market. I bought one, a single length stave, $16 \times 24$, in 1907.

I filled the silo with good ripe corn. The ripest of the corn was nearly ready to shock. Our cows, calves, hogs and horses did fine on this. I thought we never would get it fed out. We fed until the 10th of May. The cows had been on grass two weeks when we quit feeding ensilage, and don't you know those cows would come in off grass and eat a big leed of ensilage. They actually failed in milk when the ensilage was taken from them.

The summer of 1908 was so dry I concluded to build another silo, so I ordered a $14 \times 24$ from you. I will now try to tell you as nearly as possible what profit I derived from these two silos. During the winter of ' 98 and ' 99 it took 18 acres of corn to fill the silos. The coln was a short crop and would not have shucked out more than 500 bushels of corn. We filled the same silos this year with 13 acres. We milked on an average of 20 cows during the six feeding months and sold silage for $\$ 42.00$, milk for $\$ 1,210.22$. We paid for grain $\$ 3 i 5.42$, hay $\$ 50.00$, corn fodder $\$ 40.00$. This leaves a profit of $\$ 847.80$ for 18 acres of corn. We fed 50 head of stock from this 18 acres and we figure that the growth on the young stock and the manure paid us well for our labor of filling silo and taking care of the cows. I also figure that I have good pay for my corn and enough from that 18 acres of coln to pay for my two silos, which cost me about $\$ 400.00$, and my silos seem to be as good as new.

I may be giving too much credit to the silo, but I think not, as the cows I fed are very common, but thanks to the silo I will soon be able to buy better ones. I don't believe there is any better way to handle the corn crop than to put into silo and feed to good cows or beef cattle. Yours truly

GEO. L. SEBRELL.

Arbuckle, W. Va. 
Inimana Silo Co., Andersox, IND.

Gentlewen:-I bought an Indiana silo of 11. C. Hargrove in the Fall of 190s, a $16 \times 30$. I have used it two winters and think it is as good an investment as I evel made. It saves me $\$ 100.00$ or more a year. Then thill of the comtort of having your feed just where you call use it on a stormy day. It is put away when the weather is good. It leavts the glound clcan for the next elop. You have no trouble in facing the cold blizzard of winter, chopping foddel that is frozen down in a foot or two of snow. Oh, 1 pity a man or team that has 90 or 100 days of the yeal to put in this way as I served my time in this way belore the days of a silo. I would not be without a silo for twice the cost of one. It is a pleasure to do chores on a cold morning now when $I$ know my team is in a warm barn and I am only out a short time, then back sitting by a warm fire.

I keell from 25 to 30 cows and feed them bran, some bay and ensilage. I sell the milk and crean to the (. B. \& Q. R. R. for the dining cal. The cook asked what we fed our cows as the cream had such a rich golden color. I think it is the ensilage for it comes nearer sum. mer leel than any other feed l ever used. The butter is more the color of butter made in the summer.

My dry cows have been fed from ten to fifteen pounds of ensilage twice a diy. I never hat cows to come through the winter better than this year. They run in stalks part of the time. Hay is high and I had plenty of ensilage so have fed it alone. They are as fat and sleek as a mole. I have fed some to horses. I have no sheep but think it would be ideal feed as I have been told by others that use it that it is good. When I buy a new cow slie acts shy for a day or two but soon is eating it fine.

I think the silo is the foor malls frienci. The rich can get along, and let half he raises go to waste. The man with a small farm needs a silo worse than with a large one. If I were a renter I wound rent from three to ten years and if the landlord would not put up a silo I would get me an Indiana silo. It would be very little trouble to move as the staves are wholly beveled and go together nicely, so it would be very easy to talie down. One can save encugh feed in three years to pay for the siln and all expenses. Youl's respectfully,

\section{P. P. SMITH.}

Charlton, Ia.

\section{THE PROOF OF THE PUDDING IS IN THE EATING.}

INmina Silo Co., ANDERson, IND.

Gentlemen: In the tall of 1908 I put up a $14 \times 30$ silo and have certainly lomel that the proof of the silo is in erecting one, filling it with the silo feed when it is in its best condition, and that is just before tha corn starts to ripell, and you can soon find the good of it. I find that I have economized since I started to use the silo and my experience has taught me that 12 acres of fairly good coln will well fill a silo of this size, and out of this $1 \mathrm{~mm}$ feeding 18 head of cattle for about six months twice a dia and am moking 10 gallons more milk a day than when I did not have the silo and was feeling severa! lutudred dollars worth of other feed besides the hay and corn which they wele fed; so I cannot say too much in praise of it, and if any farmer wants to make a good investment I highly recommend lim to mi 11 a silo and I know he never will regret it. Yours truly,

FRANK SAPP, Amherst, Ohio. 
Gentlemen:-I put up one of your silos last September, 12x28, and filled it witl nine acres of corn. Six acres of small yellow corn which I bought and three acres of big speckled corn which I raised, which made the finest feed that I ever fed in my twelve or fifteen years of dairy experience.

I began feeding the 6 th of November and fed twelve head of cattle, fed from half a bushel to three pecks per cow three times a day according to the amount of milk the cow was giving. I also fed 40 head of hogs once a day several bushels and my chickens a bushel a day. I fed until I had my sale on the second of February and had fed less than three acres of corn. I put the three acres of speckled corn on top and I was still feeding speckled corn. I fed ten bushels of ground oats in connection with the ensilage and about half as much roughness as I did without the silo, and with about one-fourth of the grain,

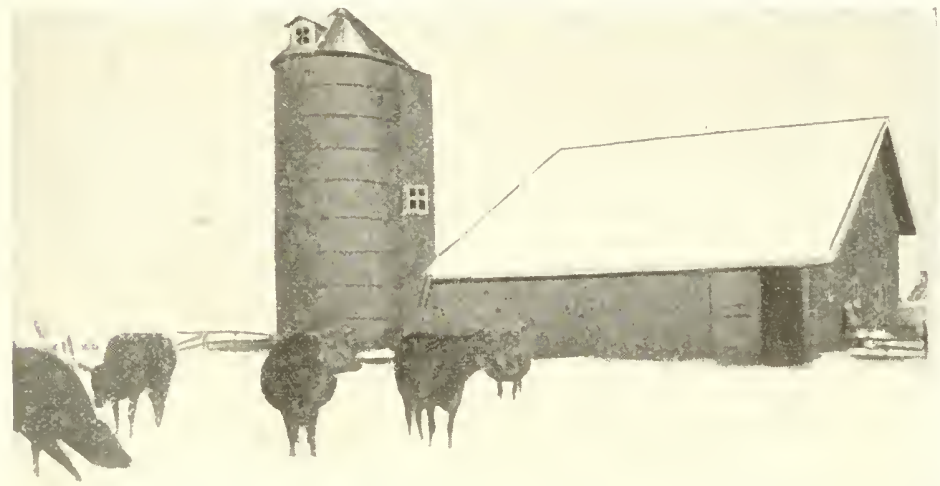

Emlyn E. Smith's Silo at Royerton, Ind.

and had a great deal better profit from my cows than I ever did. My cows done far better on the ensilage than they did on bluegrass and clover pasture. My neighbors said they never saw cows in as good a fix and doing as well in the winter as mine were. They all said it was the ensilage. I sold calves that had just been weaned, raised on separated milk, ensilage, and a little alfalfa hay that sold at my sale for $\$ 24.00$ to $\$ 34.00$. My cows made me an average of $\$ 63.00$ per head and my two-year-old Jersey male brought $\$ 79.50$ and I gave the silo the credit.

If I ever go into the dairy business again out here or any place else I will have an Indiana Silo. I think they are by far the best silo on the market. If I did not have the money to buy a silo I would borrow the money if I had to pay ten per cent. interest, for I know it will pay for itself the first year. I didn't think I could afford to buy a silo but I found out that the silo will make you able to own one and in a very few years will save you enough that you will be able to own two and have a good bank account besides. 
My advice to anyone on a farm keeping stock would be to order an Indiana Silo this Spring and put it up this Summel and have it ready to fill next Fall and get started right and get the best results out of your corn. Ilow long will three acres of corll last to cut it up and feed the old way to twelve head of cattle, 40 head of hogs and a hundred and twenty-five chickens? Yours very truly,

$$
\begin{aligned}
& \text { EMLYN E. SMITH, } \\
& 1012 \text { E. Monroe Ave., } \\
& \text { Colorado Springs, Colo. }
\end{aligned}
$$

\section{$12 \times 30$ SILO EARNS $\$ 442.43$ FIRST YEAR.}

Ixulat Silr Co., Axuerson, Ind.

Gentlemen:- I have an Indiana Silo, 12 by 31 feet, which I put up in August, 1906. I am in the dairy Jusiness and keep 16 Jersey cows.

From Silt. 1, 1905, to Selt. 1, 1906, (the year prior to my feeding ellsilaget my creamely checks amounted to $\$ 847.37$. From Sept. 1, 14116 , to sept, 1, 1497, my cluecks amounted to $\$ 1,208.55$. The same cows were in the herd botb years, excent two cows which l sold and replaced them by youngel cows.

The ration the first year was, 19 tons of mixed hay (for the whole year', one feed of corn fodder a day, 4 quarts of mill feed a day to each cow and ten small ears of corn a day. The ration the first year I fed ensilage was 12 tons of mixed hay for the entire year, two quarts of nill feed pel day to each cow and two feeds of ensilage per day. The ensilage was led from Doc. Ist to May 1st the following Spring. So the silo saved me in one year as follows:

$\$ 1,208.55-\$ 847.37-\$ 361.18$

Increase in creamery cherks. $\$ 361.18$

$1 ?$ tons hay -12 tons- 7 tons,

7 tons at $\$ 12.75$ jer ton............. $\$ 9.25$

$\$ 184-2$ (sinving on mill feed).

Total

$\$ 442.43$

So in one year my silo made me $\$ 442.43$, saying nothing of the labor saving or caring for my coln clop, that is, husling, cribloing, stacking fodder, etc.

I will also state that my cows came out in the Spring looking much betier lor having been fed on ensilage. J will also add that it took 12 arres of my coln clopl to fili wy silo in 1906 , whereas, in 1909 it took but $5 \frac{1}{2}$ alcres to fill it. This shows what the silo and cows are doing for the soil. Although the merculy here legistered s degrees below zero in Jamuary the ensilage around the walls of my wood silo was lever frozen so much but what I could easily dress it off with my six tined fork.

I visited a neighlor who has a cement block silo and looking into it saw the ensilage was frozen all around the outer edge next to the blocks from 12 to 14 inches and the tenant told me the only way he could loosen it was by the use of a grubbing hoe. If any one doubts this I can furnish the man's name to a sworn statement. Give me a wood silo every time. The man who is trying to farm without a silo is behind the times about as far as the man who cradles his wheat Instead of cutting it with a binder, or flails instead of threshes.

Ensilage is even better, if pussible, for sheep than cows. I want another silo,-if I put one 121 it will be a iul rength stave Indiana silo. Yours very truly,

E. E. SHAMAN.

Centerburg, Ohio. 
Indiana Silo Co., Anderson, Ind.

Gentlemen:- Your letter received, asking testimony on the Indiana Silo. I will say this, that if I would have known ten years ago what I know now I should have had one then.

I have one silo Irom the Indiana Silo Co. and consider it the most profitab'e investment a nian could make.

(1) Silage comes the nearest to nature's food of anything one can have for winter. Alnost everything relishes it. Even the poultry we have, about 600 head, all eat it.

(2) You take very poor or late corn, put it in the silo and I figure that one acre of this pool corn put in the silo, say it yields 10 bushels per acre, is equal in feeding value to one acre of good corn, say 40 bushels.

As I have had cows all my life and ship milk I used to grind the corn and leed it in the fodder. I never got the results out of it towards what I get out of the silo. It is less labor and expense. When I go to milk my cows' bags are just stiff, milk running out, where feeding in any other way I would get about one-half of the milk. I have 15 little calves. I feed them mostly silage and they ale doing fine without any other grain.

Yes, gentlemen, I think lots of my silo and am thinking of building another one this year.

I hope you will read my lew lines with satisfaction and allow me for them what you think they are worth. What I say are actual lacts. If you think my few words have any weight in the contest give it to me. Yours truly,

\section{MILTON THIEL.}

Hebron, Ind.

\section{KEEP THE BOYS AND GIRLS ON THE FARM.}

Ixdixa Silo Co., Axdersux, Ixd.

Gentlemen:- Enclosed find $m y$ picture. I

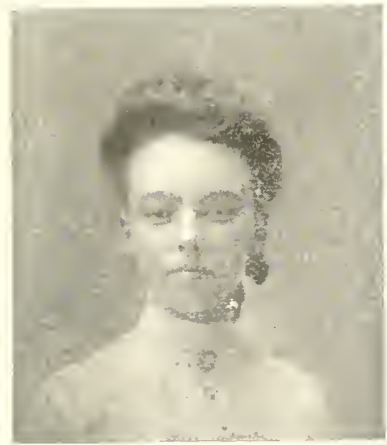

Miss Lena Saathoff, Waish. ville, Ill. am 19 years old.

It takes me about 25 minutes to leed our 19 head of cattle and put them in the barn.

Our silo is $16 \times 24$ and it only took a little over four acres to fill it. We could not have fed our cattle with that amount of fodder, and it is much bettel feed this way.

My father purchased a silo two years ago. Will say that we are well pleased with it. I would not stay oul the farm if I did not have a silo. Now I can do the feeding myself. in good or bad weather, while my father is at other work.

Our cows commence to bellow when I go to the barn and do not stop till I let them in. Even our little Angora goat eats it.

This is the first testimonial I have ever written and I think I ought to have a prize, as I believe this is the only testimonial you will get from "A Farmer's Daughter."

Yours respectfully, 


\section{WILL FEED DURING SUMMER.}

Indiana Silo Co., Anderson, Ind.

Dear Sirs:-In the year 1908 I fed 7 head of horses, 10 head of cows, 10 head ol calves of different ages. The cost of the bran for my cows was $\$ 250.00, \$ 150.00$ worth of hay, 100 sirocks of loddel worth $\$ 50.00$, making a total of $\$ 450.00$.

In the year 1909 I built an Indiana Silo and fed the same amount of stock as in the previons year. My silo holds 100 tons in which I put 18 acres ol corn. That would malie about 20 bushels per acre which would amount to $\$ 180.00$. I also raised $\$ 150.00$ worth of hay but sold $\$ 80.00$ worth, thus leaving $\$ 70.00$ in hay fed to my stock.

I now have 40 tons of silage in my silo which will feed my stock during the summer and will yet save me $\$ 100.00$ worth of bran and mill feed. Thus leaving my actual expense for this year $\$ 150.00$, compared with $\$ 450.00$ for the previous year, leaving a gain of $\$ 300.00$, which more than pays for my silo and expense of filling. Respectfully yours,

H. THOMAS.

Bloomingdale, indiana.

\section{WOULD QUIT FARMING RATHER THAN DO WITHOUT SILO.}

Indiana Silo Co., ANDERSon, Ind.

Gentlemen:- I found my silo l bought from the Indiana Silc Company entirely prefect. I never saw a silo where the ensilage kept so good near the door trame as in the Indiana Silo.

My silo cost me complete, $\$ 150.00$, which I have had one year now and I have nad 11 cows for the last three years. In the one year that I have had the silo my cows have gained $\$ 180.00$ over the two years withont one.

Another thing I have never seen feed as good as ensilage for cows. Every year my cows dil not want to lose the alterbirth but this year I fed ensilage and I had no trouble at all. Every three hours after calving they lost the afterbirth.

Next, ensilage is good to give the cows appetite. My cows never ate so good as lollg as I have been farming as they do now.

I would rather not be a farmer than to be a farmer without a silo. Yours truly, JOHN URBAN,

R. F. D. No. 34, Box No. 97. Elkhart, Wis.

\section{INDIANA SILO CUSTOMERS MAKE MONEY.}

Indiana Silo Co., Anderson, Ind.

Gentlemen:- In regard to your recent request will say that I had great results from the Indiana Silo, and about the leaking part will say it doesn"t leak or freeze a bit more than a stone silo. And besides that the first soft day we have it comes off and the silage is just as good on the side as in the niddle. In my judgment I prefer the Indiana Silo to a stone silo. I must say that the Indiana Silo saved me about $\$ 200.00$ in hay last year. That is not bad.

Now in the ground feed, bran or corn, the Indiana Silo saved mo $\$ 150.00$. That is in fine feed. Was a big price last year, but a farmer with an Indiana Silo makes money. If he doesn't it isn't the Indiana Silo's lault. Yours truly, HENRY VAN DE HEI, 


\section{PREFERS STAVE TO CEMENT SILO.}

Indiana Silo Co., ANDERson, Ind.

Gentlemen:-A little more than a year ago I became somewhat aroused in dairying and was led to purchase, a little later, a few head of registered Jersey cattle. The question of how to feed for the best profit then confronted ine. Upon consulting farm papers,. dairymen that 1 happened to meet, and Bulletin 155 of our Experiment Station, it dawned upon me that a silo was necessary for most profit. Then the question, "What shall I build, cement or wood?" It became my privilege to visit a farm where a cement and a wood silo stood side by side and filled nnder like conditions. Being interested and desiring the best, I asked, "Which silo do you like best?" The answer was, "We throw a great deal more spoiled ensilage out of the cement silo than the wood. We like the wood silo the best." Upon examining catalogs of different makes of silos I decided the Indiana Silo had them all beat, so I purchased a small one. One year's experience has been so satisfactory that the small one has been sold to a neighbor and is being rep aced with a larger one.

Why am I so well pleased? Because I can make one acre, by feed. ing silage, do what two would the old way of feeding. The year previous I found it took 25 pounds of hay for one cow. Ten cows consumed 250 pounds a day. In 180 days they would consume $22 \frac{1}{2}$ tons of good hay. Three and one half acres of corn filled my silo, which will feed ten cows 180 days' full feed of 40 lbs. each daily. We feed a little hay in connection with silage but find a cow that eats 40 lbs. of silage will eat very little hay. We fed less than four tons of hay to the ten cows, or two acres of hay. Three and one-half acres of silage and two of hay make five and one-half acres to feed the ten cows 180 days. Twentytwo and one-half tons of hay in the same field where the corn was raised for silage required $111 / 4$ acres to produce it. The cows produced more on $5 \frac{1 / 2}{2}$ acres where silage was fed than on $11 \frac{1}{4}$ acres of the clover hay.

The silo has exceeded my expectations and I know that one who does not feed silage cannot compete with those that do feed it. I take great pleasure in recommending the Indiana Silo as a money saver, for feed in these times means money. Yours respectfully,

C. A. UNDERWOOD.

West Mansfield, Ohio.

\section{WOULD NOT HAVE MADE A CENT.}

INDIANA Silo Co,, ANDERSON, IND.

Dear Sirs:- You aslied me to send you an article concerning my silo for your contest.

I put up a $16 \times 30$ silo last fall and have fed 20 head of milch cows and 10 head of young stock on the silage since November 20 th, besides feeding it to my calves, chickens and pigs, and I never had my stock in as good condition nor my cows give so much milk in the winter time at so small cost for feed, and I have enough silage left to feed the stock for two months yet. My cows did not eat to exceed eight pounds of hay apiece each day. It cost me on an average of $18 \mathrm{c}$ a day for roughage and grain for my cows and they paid me a good profit in butter fat and if I had had to feed them all hay for roughage at the prevailing price I would not have made a cent. I know by this year's experience that silage is the cheapest rough feed on the farm, even cheaper than pasture.

Wishing you a prosperous year, I remain, yours sincerely,

T. C. THOMAS.

Goodell, Iowa. 


\section{INDIANA SILO COMPANY FULFILLS ITS CONTRACTS.}

INdixa Silo Co., Axderson, Ind.

Gentlemen:-In regard to feeding silage to beef cattle for profit, I will say that I have been in the cattle-raising business for the past thirty years. It was formerly my custom to feed liberally with corn dming the winter months, which was very expensive, and finish on grass, but leed stutts are now becoming too high to feed attle profitably in that way.

Five years ago 1 bought an Indiana Yellow Pine silo, which is still in the very best state of preservation, and since that time have fed silage to all classes of farm animals with good results and quite a nice profit over what I formerly thought was a good profit. The silo has also increased my leeding capacity at least onethird. I can furthermore say that I have never had cattle go off of feed on silage as they will some times do when led a heavy grain ration. It is a well known fact that wet shock curn from the field has a tendency to scour cattle which nevel occurs when ferding silage. Cattle will go on grass in the Spring with lar less shrinkage than when fed dry leed. The solution is simply this, that they lo not need to go through that radical change from dry leed to a succulent one.

The first year I nwred the silo I kept no record of profits, but when Spring came I found enough hay in the barn to more than pay for my silo, which other years would have been fed. This alone was enough to convince me that the silo was a great investment.

The following lacts and figures are of 31 grade shorthorn steers which were bought locally at an average rost of $\$ 4.15$ ver cwt. in the Fall. These sterrs went into the feed lot on Jan. 1, 1909, averaging 960 lbs. on a ration of com silage, shock corn and linseed meal. They were fed this ration tor 120 days or until Nay 1st, when they were turned on clover and timothy pasture. They sold July \&, 1909, averaging 1,371 lbs. and sold at home for $\$ 6.35$ per cwt, making a total gain of $410 \mathrm{lbs}$. per head or 2.19 lbs. per head per day, therefore.

31 steers Jan. 1 , $199,29,790$ lbs, at $\$ 4.15$ per cwt.

8.5 to $! n$ tons silage at $\$ 3.00$ per ton

$\$ 27000$

15i) $0(1)$

300 bu. shock corn at $50 \mathrm{c}$ jer bu...

2 tons linseed meal at $\$ 30$ bel ton..

68 days pasture at $\$ 1.50$ per month per head

Total cost of fetid
(6) 00

105.10

Cust of cattle and teed

July \&, 0 , selling frice 31 steers 12.500 lbs. at $\$ 6.35$.

Jan, 1, wi, cost mice 31 steers 29.780 lbs. at $\$ 4.1 .7$

$\$ 1,235 \times 17$

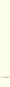

$\$ \quad . \times 540$

$\$ 1, \$ 21 \div$
$\$ 2,6 ! 9875$ $1,295,57$ $\$ 1,46288$ 58540

Less value of teed

Profit on hogs following

$\$ 1,047 \quad 48$

'lotal net profit...

These steers were very fat when sold and demanded the high price
he season in our lorality. In fact I do not believe that I realized of the season in our locality. In fact I do not believe that I realized were most 100 iat when turned out.

I consider the silo one of the best investments any farmer can malie, either large or small, and the only thing I regret is that I did not erect one fifteen years sooner. I have a neighbor who claims be can winter 
his cattle as cheap on silage as he can graze them. I do not hesitate to recommend the Indiana Silo as it is superior to any I have seen both in ivorkmanship and quality.

As to the Indiana Silo Co. I can say that they have always fulfilled contracts with me to the letter whether made through their represontatives or direct. It is certainly a pleasure to do business with such a tirm.

Thanking you for your conrtenus treatment in the past and wishing you success, I am, yours very truly.

D. K. WILSON.

Tariton, Ohio.

\section{USED SILO FOR TWELVE YEARS.}

Ixdiaxa Silo Co., Anderson, Ixu.

Gentlemen:-1 received your letter of inquiry in regard to the profits received from the lise of silo feed. I have fed this feed now about 12 years. Of course I had a very inferior silo to start on but since I bought of you I find $m y$ profits much greater. I ran out of silo feed in April. I was then shipping milk to Jessup \& Antrim. I shipped 48 gallons per day. I had a herd of 14 cows, part of them nearly dry, and I was obliged to feed dry fodder which I cut fine and mixed the same amount of other feed with it, as I did when I

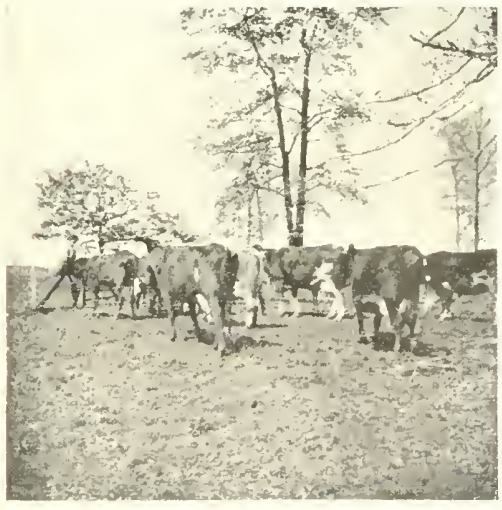

Mr. Neimeyer's Dairy Herd, Ben Davis, Ind.

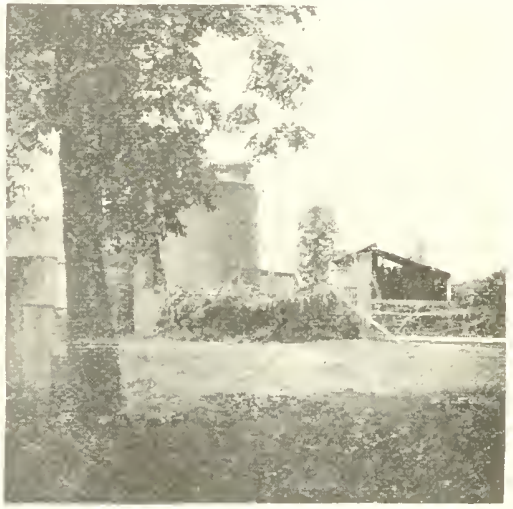

Filling Mr. Neimeyer's Silo.

fed silage, and in three days from the time I made the change I lost $s$ gallons of milk, which at that time sold for $\$ 1.00$ per can of 8 gallons, or $121 \% \mathrm{c}$ per gallon, which would be $\$ 186.00$. My loss in that one month was $\$ 1.00$ per day, which means 31 days, $\$ 31.00$.

I also find my stock heeps in better flesh. I bought a bull for $\$ 14.00$, two years old and desperately poor. In 18 months he weighed 2,020 pounds and was sold at the stock yards by Mr. Sells for $\$ 87.50$, a difference of $\$ 73.50$, besides the use I had of him.
C. H. NEIMEYER,

R. F. D. No. 21,

Bridgeport, Indiana. 
IndiNA Silo Co., ANDERSON, IND.

Gentlenten:- I bought a 14x30 Oregon Fir, stave silo, of your agent, Mr. Bowler, and to say I am well pleased with ny purchase is but mildy expressing my appreciation of same, and what it has done for me.

I have fed twenty-five cows and heifers, fitty liead of sheep twice a day, forty hoss, six herses and thlee colts once a day. Started to feed the first of November and will have more than 1 will use in feeding until May $15 \mathrm{th}$, but will appreciate having some lor July and August. I think that the corn crop put into a sio will make double the money that it will in any other way and especially in a dairy comntry. I think that for any one living on land selling for $\$ 100.00$ to $\$ 150.00$ per acre it would be a very wise plan to cut the lusturage down and build enough silos to feed the year around. I hope to have anotliel the same as the one I now have in the neal iuture.

I cannot say too much for ensilage as a feed for all kinds of stock, and think anyone in the coln belt who does without one is doing an injustice to lnimself and stock, and in purchasing think it impossible to do bettel than to deal with the Indiana Co., as I have found them to be right and to sind just what they represent.

Hoping that all users of silos are as pleased as I am, I lemain,

JESSE UTTER.

Stoughton, Wis.

\section{ALFALFA MAKES GOOD ENSILAGE.}

\section{I'DiANA SILU Co., ANDERSON, IND.}

Gentlemen-I keep a dairy of forty cows on my little farm west of town and raise alfalia to feed them, and I have nevel found anything to compare with it for producing milk, although we often experience some dilficulty in taking care of tle first crop on account of it coming during the spring latins.

Tin years ago l had a big yield and as the weather was bad for culing liay I colleived the idea of filling a vacant ice house with alfalfa as it it ll from the mower, tramping it in as best we could and awaited results. Soon after we began feeding it to our cows and I was so well pleased that it did not take much persuasion to sell me an Indiana Silo, which I filled last Fall with silage corn and green alfalfa after running it through an ensilage cutter, alternating each load until the building was two-thirds full, when the coln ran out and the balance was filled with the lourth cutting of alfalia.

The past winter, as everybody knows, was a very bad one for the average dairyman, but we kept up our flow of milk better than ever before in winter and with little ol no grain, which was a great saving in experse.

I shall fill my silo at least one-third full of the first cutting of alfalfa and the balance will handle the same as last year. I not only wintered twenty brood sows and shoats on ensilage, but twelve calves that could not liave gotten along without sweet milk, which would have brought the cost of reartng to a prohibitive price. I think they are the best lot of winter calres I ever had anything to do with.

I built an alfalfa barn last summer and I now regret that I did not put the money in two silos, which I might have done and had a superior feed for my stock.

O.E.WALKER.

Sheridan, Ind. 
INdiana Silo Co., ANdetison, Ind.

Gentiemen:-1 bought an Indiana Silo in 1908 , 14x26, two-piece staves,-filled it with 12 acres corn that would make 25 bushels per acre. Took one and one-half days to fill it at $\$ 40.00$ per day for everything. Was inexperienced in silo filling and let the fodder get too dry, did not wet it, so it did not keep very well. Fed it to the milch cows seven months and twenty head stock cattle for three months all they would eat, besides ten horses once a day. Kept no record of milk, but

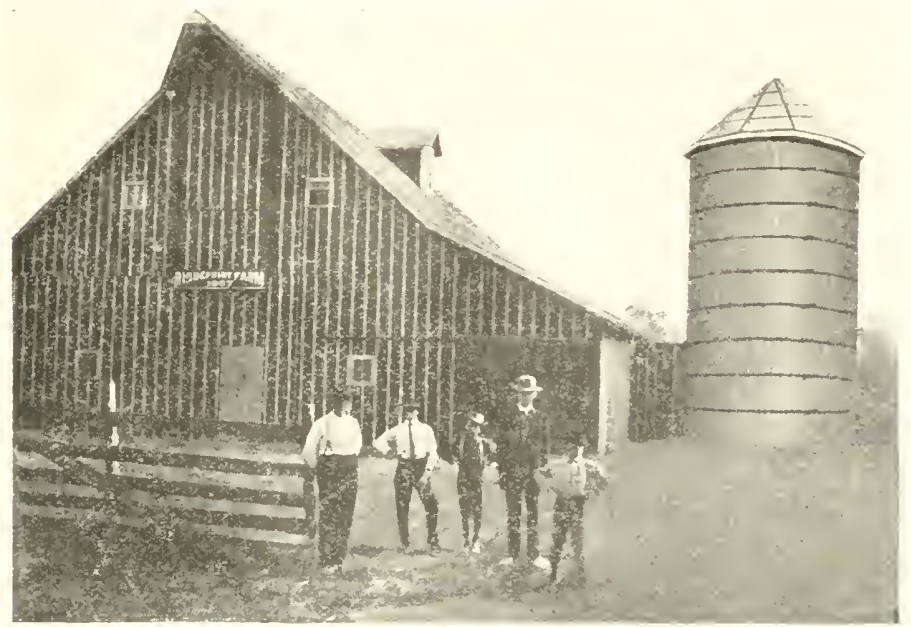

Buildings on Ridge Point Farm of W. W. Willeford, Greenville, III.

the stock cattle gained one pound per head per day for the full time. Filled silo with green corn last year and it is relished much better by my stock.

I send you a poor photo of my barn and silo for I want that book. How soon will it be printed? Yours truly,

W. W. WILLEFORD.

Rural Route No. 7, Box No. 44.

Greenville, Ill.

\section{STARTS HENS LAYING.}

Indiana Silo Co., Annerson, Ind.

Gentlemen:- I received your letter the other day in regard to your silo. It is the most profitable building on the place. It has paid for itself in one year, saving fifteen tons of hay the first year. I am feeding now 36 shoats, 40 sheep, 28 head of cattle, 5 horses and 128 chickens. It Is very nice to start chickens to laying. Twelve cows brought me $\$ 122.75$ in the month of January. I am very well pleased with the ensilage. Five of my neighbors who liave looked at the lumber in the silo, say that the Indiana Silo is the only kind they will build. Yours truly, 


\section{WAS DISCOURAGED BEFORE HE HAD SILO.}

IndiNa Silo Co., Axlerson, INT.

Dear Sirs:- I lure been in the aairy business for the past ten years and was beginnirg to be discouraged when at lasi I turned to the silo and as there are a number of different kinds of silos I began to investigate and found that the Indiana Silo was giving the best results at the least expense to the tarmer, so I decided to build one. It is now over a year and my silo is paid for many times, I can honestly say that dairying without a silo is a tailure.

I will try to explain what the lndiana Si?o has done for me:

I have the (inernsey cattle and find them good inilk, butter or cherse producels. My herd of twenty five grade Guernsey cows used to furnish me $\$ 7$ t. is por month, but the feed cost me $\$ 53.12$ per month, learing $\$ 21.16$ gain per month. This year from the sane cows I received $\$ 146.85$ yer month and the cost of the feed was $\$ 38.20$ per month, leav. ing a gain of $\$ 10 \$ .65$, or $\$ \$ 7.45$ per month to the credit of the silo. Yet this does not give the Jndiana silo enough credit. Words cannot express 111 satisfaction liom it. Now if these few lines will help to introduce the Indiana Silo you are entirely welcome to them as 1 am well pleased and will recommend the Indiana Silo to anyone. Yours respectfully,

CONRAD VENHANS,

R. F. I). No. 1,

Fond dia Lac. IVis.

\section{LET THE SILO BE THE NEXT IMPROVEMENT.}

\section{InilanA Silo Co., Anderson, Ind,}

Gentlemen:- In reply to your Jetter of $M$ arch 16 th offering $\$ 50.00$ in lrizes for the three best articles on the protits of using a silo, I would say that I cannot give exact figures showing just what the profits from the use of my silo are lut I feel that for feeding dairy cows or grow ing stock the feeding value of an acre of corn is increased from 50 to 1014 per cent. Preserving the plant at a time when its appetizing and uutritive cualites are at their best, and most evenly distributed throughout the stalk, is a great factor in getting the largest possible feeding valuw of it togetlee with the smallest of visible waste and consequently the largest cash returns. These things the silo does effectively.

Stock does much letter than on corn fodder and cows give more milk on it. This increased thrit and production is money in the stockman's or dairyman's pocket. Putting a corn crop in a silo saves shocking ant stacking or hlisling and does away with all probability of being (anght by a deep snow with your rorn in the field, often so tightly llow $n$ down that it is impossible to get out. The increase in net returns lrom feeding corn lodder and heing sure that your corn crop will be where you can get it for feed in the cold winter weather, with less expense of labor than is refuired to harvest it any other way, is a good reason for making the silo the next improvement on your farm. If you raise coll for roughage a silo will soon pay for itself and the rest of its days it will put money in vour pocket by increasing the value of your corn crop, stopping the waste of a large part of your fodder, and fur. nishing you a feed that comes nearel equaling nature's balanced ration, grass, than any other single thing that can be found in the winter. Respectully,

C. H. WIINN,

P. S.-Photo of barn and silo sent under separate corer.

Bemis, S. D. 


\section{FACTS ARE GOOD ENOUGH.}

Indiana Silo Co., Anderson, Ind.

Gentlemen:- Your letter of Jan. 24th is at hand. In reply will say I regret that I cannot give you the complete analysis of my feeding operation in facts and figures. All I can give you is the facts.

This is my second winter to use an Indiana Silo. So far 1 have given my silage to all kinds of stock with very gratifying results. I feed it to cattle of all kinds, horses, colts, etc. This winter l am feeding 35 head of cattle and 4 head of horses, and have plenty of feed to put them through the feeding season, but before I had a silo, from 10 to 15 head of cattle was all I could handle during the winter, and even then I had to get lots of feed away from home every spling to feed till grass was ready as I have a small farm, less than 40 acres in cultivation. $I$ would not think of working a farm without a silo, as the silo fully doubles the feeding value of the colll crop.

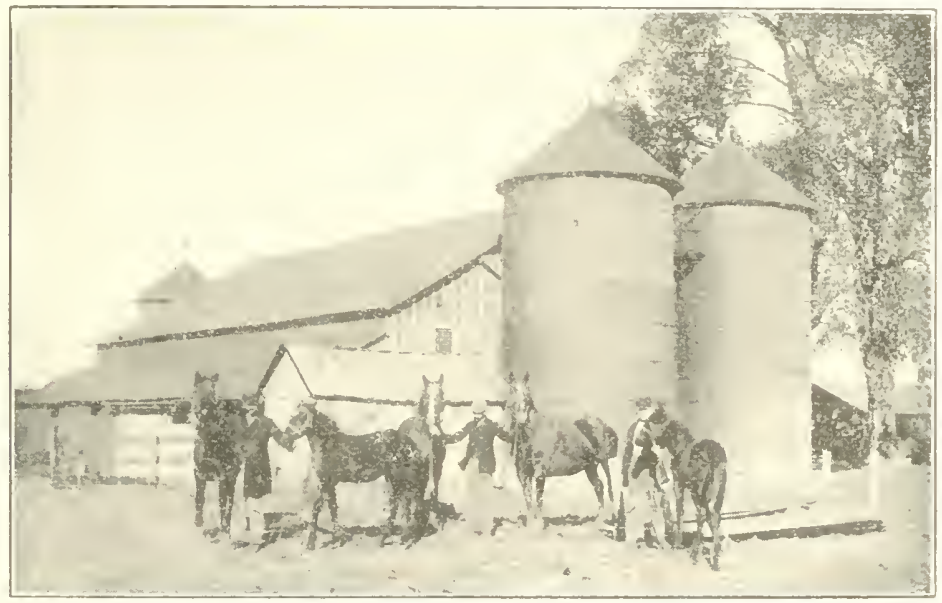

Walton \& Butler Believe in Having Plenty of Silage.

Several of my neighbors are using Indiana Silos and all are well pleased. Some of them are feeding steel's in such a mannel as to give a complete mathematical analysis of their fecding operations when done. I will gather and send you this information as soon as they are done feeding.

Sent you our plioto some time ago. Yours truly, JOSEPH M. WALTON.

Baders, Ill,

INDIANA Silo Co,, ANDERSON, IND.

Gentlemen:-Until recently I have never been very much interested nor believed in silos, but having seen some of the results of silage feeding I believe I can safely say the bellefits are equal to fifty per cent.

W. D. WHITTINGTON,

Herrick, IIl. 


\section{Ivinana Silo Co., Anderson, Ind.}

Gentlemen:- You ask my experience in the use of one of your silos. I have had one nine years and the difference to the man who has one and the one who has not in my judgment is you can keep at least $1 / 4$ more cows on say 12 acres of corn put into the silo than the man without one. Then you have the corn in shape to feed early and dou't have to dig the stalks out of the snow. Then with food corn you can get as mueh milk in the wintel as when they are on the grass, and if you have 6 to 10 feet left in the silo in the spring commence feeding when your pasture is getting short and your cows will not shrink as they do during fly time.

In the year 1907 we milked 15 cows; 5 of them were two-year. old heifer's. They freshened in December, 1906, and January, 1907. We received lrom the cleanlely $\$ 94.00$ from each cow. The corn that we put in the silo grew on 10 acres. They were fed two bushels per day in two feeds and clover hay at noon. Then we partly wintered 8 yearling bulls and 4 heilers. One week in February we fed out corn stalks the same as we put in the silo and they dropped from 600 pounds daily to 400 pounds, otherwise they were fed the same. We then led ensilage and they went up to 600 pounds. Then they were fed on fouder left out in the tield part of the winter,-at least onetourth.

I think I was the first one to put up a stave silo in this town and now alnost every farnier luas one. I can count 14 from my place.

In regard "o the life of a silo, mine with the exception of a collule of inches at the lower end of staves is as good as when put ul) and I was to blame for mine rotting where it did as 1 put cement up fom inches on outside of staves and the rain runs down the staves and inside of the cement and cannot dry out, so must rot, but in ont-half a day I can saw off these few inches of decayed staves, let the silo dowu on the stone wall and it is as good as when bought. Nine year's use of a silo at a cost of only four inches at the bottom of your silo. I think some of putting up another silo and if $I$ do it will be an Indiana Silo for I have moof they will last. Yours truly, HENRY WALSH,

Elmwood Stock Farm, Sheboygan Falls, Wis.

\section{MADE YELLOWER BUTTER.}

Indina Silo Co., Anderson, Ind.

Dear Sirs:- We purchased a $12 \times 2+$ foot silo of your agent, Mr. Cline. We think there is no feed as good as ensilage. It is next to gras 3 and is certainly one of the feeds for all stock.

The Indiana Silo is as necessary on the farm as the granary.. Silage saves storage room and is the closest way to pack the corn crop. It clears the ground "ally and entire:y for a fa'l crop. It saves labor of husking. Cattle young and old look as though they were on pasture.

The Indiana Silo is smooth on both sides, making it one of the best. Last winter we bought bran and gluton, this winter our cows had ensilage and rough feeds. They made more, and yellower butter.

We cannot recommend it too highly. Yours very truly,

A. E. WENGER.

Elkhart, Indiana. 


\section{SHREDDED FODDER HALF WASTE.}

IN̈)iAna Silo Co., Anderson, Ind.

Gentlemen:-I am in receipt of a letter from you dated January 19th stating that you would give prizes on letters showing the actual ¿dollars and cents made by using a silo. As I am no longer at home I did not receive your letter but my brother sent it to me so I am going to write you from my own experience giving you the cost of filling and the comparison between having a silo, buying bran and having corn shredded and then getting it ground.

First, it took us one week to fill our silo, which is $14 \times 24$, three msn. one team, two wagons, a $6 \mathrm{H}$. P. engine, 1,500 lbs. of coal, an Appleton twelve inch cutter, two gallons of oil and one corn harvester and received $\$ 1.10$ per cwt. or $\$ 3.57$ per day, with a cost of $10 \mathrm{c}$ per day for silage with no waste. I find when drilling corn for ears you must have lt not less than 10 inches apart. For the silo it can be 3 or 4 inches apart, thus more than doubling the crop. If you shred your corn they charge on an average of $3 \mathrm{c}$ per bushel. It takes a good crop to yield 100 bushels per acre, at a cost of $\$ 3.00$ for husking. Now if you want to feed the ears to cows they must be ground. Fifty bags at $5 \mathrm{c}$ per bag or $\$ 2.50$ per hunared bushel. So the 100 bushel of ears cost you $\$ 5.50$ before they are in a condition to feed them. It is not a balanced ration, on this same acre. You could raise about 7 or 8 ton of silage corn with a cost of filling of $\$ 35.00$. Our neigh' or bought $\$ 120.00$ worth of bran, or 6 tons. Ile fed 16 cows and got $300 \mathrm{lbs}$. of mill per day at $\$ 1.00$ per hundred. He fed 16 lbs. of feed to each cow per day or 246 lbs. to them all per day costing him 49 1-20c per day leaving him a profit of $\$ 2.491920$ per day. We had twelve cows, fed $40 \mathrm{lbs}$. of silage to each per day and received $325 \mathrm{lbs}$. of milk per day, about $\$ 5.00$ and then have no waste while the shredded fodder is about half waste. So you can see the profits of a silo.

Hoping I may be successful in winning a prize and wishing you success, I remain as ever, Yours truly,

JOHN W. WEBB,

Watertown, Wis

\section{THIRTY-THREE ACRE FARM RETURNS $\$ 1,400$ IN ONE YEAR.}

Iviniana Silo Co., Anderson, Ind.

Gentlemen:- Your letter of recent date at hand in regard to my experience with silo feeding.

This is my second season with the Indiana Silo and I am satisfied that it is the only way to get a profit out of our high priced land. I have but 33 acres but I am carrying 18 head of stock, 9 cows in milk, 6 yearlings and three horses, besides a number of hogs. Last year I fed from the silo nine months. This year I shall feed every month in the year, using green rye, clover and peas for summer silage. My sales from the farm the past year were $\$ 1,400 ; \$ 474.00$ of that I received for small fruit, the balance was the direct results of silo feeding and would not be possible under any other system. This is more than double what I have made from the place in any one year before.

All stock are maintained on the farm with the exception of mill feed. The silo more than paid for itself the first year and I thank you gentlemen for persuading me to buy one of your sios. Also for the courteous treatment I received, and wishing you the success you deserve, I remain with you for better farming.

JOHN W. YATES, Burnett, Wis. 
INDIAxA Silo Co., ANDERSon, Ind.

Gentlemen:- In regard to the value of silage I will say that nobody can run a dairy and stock tarm protitably at the now-a-days ruling high prices of feed stuffs. Corn, oats, bran, hay and a most any food stuff is high in price. My experience without a silo was that I needed $\$ 254.00$ of meal and grain for my little her of eight cows in 6 months, besides the corn stover and hay. Atter purchasing a silo I increased my herd from $\&$ to 16 head and fed only $\$ 14 \$ .00$ worth of meal and grain in 6 months, hesides hay and corn stover. That would leave me a net jorotit rill $1 \mathrm{f}$ rows of $\$ 360.06$. And then what counts still more to the

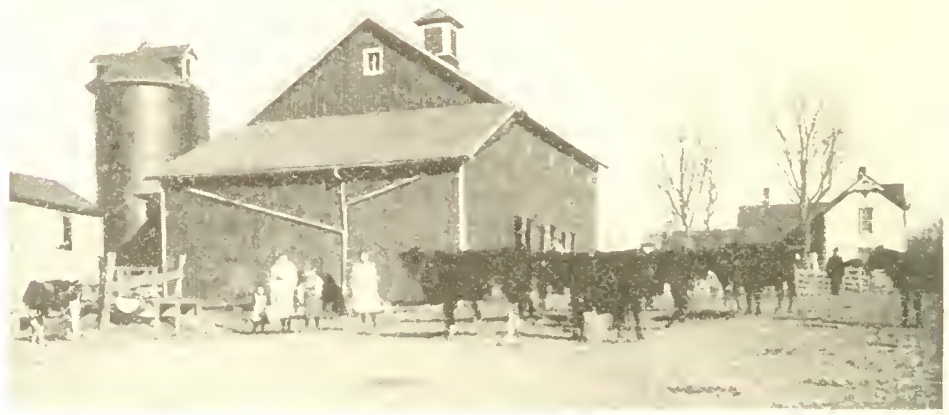

Farm Buildings of L. G. Ziegler, Effingham, III.

value of silage is this: 'The corn and other feed stuffs were lower in price as they are now-a-days. The corn I put in the silo I bought from my neighbors for $\$ 25.00$ in the field with which I filled my silo, $12 x 24$. That feeds my 16 head of cattle for 6 months and keeps them in good order a gool deal better than 1 was ever able to do before I purchased an Indiana silo. There is no question with me that it is profitable, not unly in saving quite a smug sum every year in feed stuffs, but on the other hand by feeding good silage it increases the flow of nilk a good many per cent. The money I have invested in the silo pays me 50 ler rent on each dollar every year since I purchased it in 1908.

LOUIS G. ZIECILER,

R. F, [), No. 2,

Effingham, Ill.

\section{SAVED THIRTY TONS OF CLOVER HAY.}

Indina Silo Co,, Anderson, Ind.

Gentlemen:- I wish to state that I think a silo is all light. As to the exact amount of money I saved with a silo it is hard for me to tell, but I saved at least 30 tons of clover hay this winter, which has been worth from $\$ 13.00$ to $\$ 18.00$ a ton. Besides I saved a good deal of ground feed which is worth flom $\$ 25.00$ to $\$ 35.00$ a ton.

G. W. WIGGERS.

Muscatine, Iowa. 
Indiana Silo Co., Anderson, Ind.

Gentlemen:-It was some time before I could make up my mind that it would pay me to put up a silo, as there was no one in the neighborhood who could give exact figures. But finally decided to try it for the following reasons:

I had but ten acres of pasture for six cows which only gave them plenty of feed for a few months in the year, causing me to feed for the balance of the year, and if I could keep off of the pasture until it got a good start I could have plenty pasture for the summer months, which I did, not turning on grass until June 1st. So in the fall of 1907 I gave my order for a silo and before the time of delivery came seven of my neighbors did the same thing.

Now for results: In the year from Nor. 1st, 1907, to Nor. 1st, 1908, (I give these dates as 1 commenced leeding silage Nov. 1, 1908), I had 6 cows 12 months and one seven months or one cow for 77 months and one heifer, also three horses. They consumed the fodder from 10 acres of corn and 7 acres of good mixed hay, besides the green feed cut for the cows in the summer and fall months. One hundred bushels of corn and one ton of bran in the winter with the result that I sent to the creamery for the year ending Nov. 1, 1908, 21,130 pounds of milk, making 959.2 pounds of butter fat. Now for the past year to Nov. 1, 1909, I had five cows 12 months, one 8 months and one 7 months or one cow for 75 months and three heifers and the three borses, They consumed the silage in a $10 \times 24$ silo, $72-3$ acres of corn fodder and 7 acres of good mixed hay with no other corn but what was in the silo and 1,400 pounds of cotton seed meal. I sent to the creamery this year 25,168 pounds of milk making 1,249.1 pounds of butter fat, making a difference in favor of the silo of 4,038 pounds of milk and 289.1 butter tat.

I used the same quantity of milk in the family of seven and vealed the same number of calves both years. I would have felt paid if I had come out even in dollars and cents for the fine condition the cows came throngh the winter and extra amount of manure made.

Now for expense: It cost me $\$ 10.00$ in cash to fill the silo for machine and coal. For help I exchanged with my neighbors which did not take any more time than it would to take care of the corn in the oid way and the corn was out of the way for wheat seeding.

E. D. MOORE, Jr.,

Pataskala, Ohio.

Trmaxi Silo Co., Andersox, Ixm

Gentlemen:- In reply to yours of Jan. 19th, I notice my first year's experience with a silo: I did not include the cash receipts as the price of butter and veal calves vary, ut the pounds of milk and butter fat give the exact difference, but if you want the cash returns here they are, veal calf sold included:

Total cash receired year ending Nor. 1 , '08, $\$ 269.57$

Total cash received year ending Nov. 1, '09, \$366.38

Yours very truly,

E. D. MOORE, Jr.,

R. F. D. No. 4,

Pataskala, Ohio. 


\section{RUNS WATER INTO BLOWER.}

Indixa Silo Co., Anderson, Ind.

Gentlemen:-I received a letter some time ago asking for your cus. tomers to write articles on the use of ensilage. Now, I am practically a new silo man. I put a silo up last October and my corn was rather too ripe before we could get it filled, but we ran a stream of water in the blowel all the time and we have the best feed I ever saw.

We are leeding 100 head of cattle and have been for two months, and I have never seen cattle do so well in my life on any kind of feed. I just simply think that my silo has paid for itself this season. I have handled cattle my entire lifetime, and I believe a silo is the best investment I evel made. Everything is so content when they get their fill of ensilage that they lie down and no runing around or falling like they

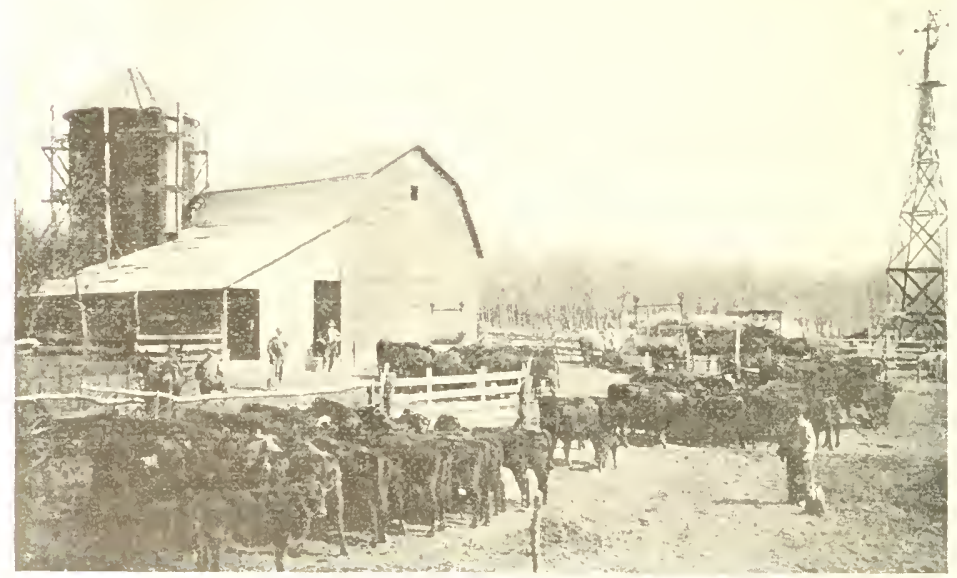

M. C. Ohl's Angus Eating Ensilage, Madison, S. Dak.

usually do this time of year. It is a comfort to take care of stock when they are content. I believe that a man ought to have a silo for every 60 head of cattle.

I am sending you a plioto of my silo and stock, which you wanted and you may send what you wish to pay for same. I expect to sell a lot of silos in this part of the country.

I wish you could send me a man to help me a few days. I have had the promise of a man from Mr. H. C. Hargrove, but he has failed to come as agreed.

Hoping to hear from you soon, I am, yours truly,

M. C. OHL,

Madison, S. Dakota. 
Indiana Silo Co., Anderson, Ind.

Gentlemen:-In reply to yours of the 15 th, I will say that I am using two of your Indiana Silos. These two silos more than paid for themselves the first year they were filled. Since I began using your silos I get just two times as much feed off of an acre of ground as I could before, and as I am in the dairy business, I have just doubled the number of cows for which I could hardly raise enough feed before I began using your silos. As silage is so much better feed than the dry feed we used to raise, that alone will pay for a silo in a very short time.

I figure that my silage cost me just $\$ 1.20$ per ton for raising and

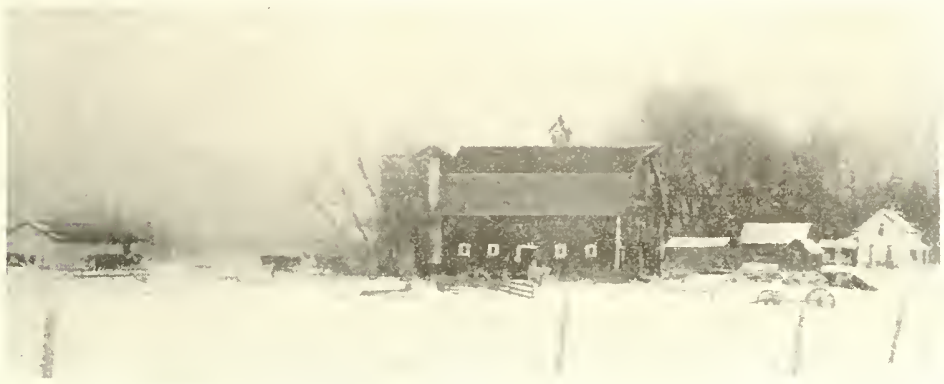

Winter Scene on Lyman Nelson's Farm, Kanawha, Ia.

putting into the silo. I don't see how a man can get any cheaper feed than this. This winter, I am getting just $\$ 2.00$ for every $\$ 1.00$ I am put. ting into my cows.

I have ordered my third Indiana Silo which I will put up this summer for summer feeding as I can get along with very little pasture then. Last fall my cows would leave a good clover pasture and go for their silage.

I am right here to back every statement I have made in this letter to ally one who may doubt them. Yours truly,

\section{LYMAN NELSON,}

Kanawha, Iowa.

\section{HAS BUILT A SECOND SILO.}

Indina Silo Co., Annerson, Ind.

Gentlemen:- I will inform you what I think of the Indiana Silo. I think they are without any doubt the best on the market and so far as feeding silage I think that no man can afford to be without a silo who has forty acres of land or more.

I have two Indiana Silos. I put one up two years ago and one last year and they don't owe me one do'lar now. I used eight acres of corn last year and fed forty head of cattle and thirty head of horses without any other grain. I fed about ten ton of hay and this stock is in better shape than I ever had them before.

I think a Silo is the most profitable building on the farm. I can't say too much for the silo. Yours truly,

ELI YODER,

R. F. D. No. 3, Wellman, Iowa. 


\section{A TREASURE GREATER THAN A GIFT FROM THE GODS.}

Indiana Srlo Co., Anderson, Ind.

Gentlemen:-Soon after I got acquainted with our silo, which the An. lerson people sent us five years ago or more, I found myself often saying that it is the greatest thing that was ever done for the farmer. That thought has never lett me nor changed a particle. The man who has a silo has a wonderful treasure. When I carry the smoking hot ensilage around the lows of waiting cows these cold days I say, "Yes, its just as il the fabled Gods of Greece and Rome had come to the farmer's relief and dropped this wonderful tank into his barn yard." Now fill your barns to bursting with your splendid hay and stack the over plus, then long before the winds blow and the rains, mud, and snows conse, cut the King of Crops, green, juicy, rich, every inch that stands above ground and rack it down nicely chopped in that wonderful round barn. What a delicious dream has come true. How rich you are; what months of luscions feeds are piled up in the handiest place in the world. No windrows of bleached corn leaves a foot deep along the fence rows; no butts of corn stalks three feet high standing and wasting all over your corn fields and in the way of next year's crops, all that waste of leaf and stalk is feeding the cows for weeks now and dropling in golden coin into the pocketbook day by day; no shivering men and horses hanling in the half wasted shocks in the snow and mud and rain, but all the old wastes even lying canned, now, ripe, rich and juicy almost right against the cows' mouths. An enchanting vision realized; a different world from your boyhood's; the Gods have been at work on man's behalf; a hundred tons of rich September canned for hungry February's needs, which used to be all but wasted; nearly a lnumded tons of has saved to the mows or for the hungry spring buyers. A hundred tons very much like bank account so that a man who has a silo is a king. This is what the ages waited fol but died without. Hurrah! We have it on our farm. Now imagine that the grippe has prostrated all hands and mows are empty, no one can haul in the stacks of hay. Why there stands the greatest thing on the farm with its row of doors right against your feed room. Draw on your silo. Now watch the greedy lrionds who used to have a big corn field ready and chose to hlcel you about one hundred and ninety dollars for your herd's needs from January to May. How sick they get now-a-days when you tell them our silo has long since stomped that foolishness forever.

Yes, the silo is it, and the silo farmer is a happy man and you can't have our silo for a thousand dollar bill.

\section{H. MCMILLAN \& SONS,}

N. Vernon. Ind.

\section{PREFERS ALL WOOD DOOR FRAME.}

Indina Silo Co., Anderson, Ind.

(ientlemen:-In leply to your letter l received a few days ago regarline the silo which I bought of your agent two years ago will say I like it just fine. I think it was tho best investment I have made for somu time. Your ail wond frame for doors I believe is better than the steel. The arid from silage will rust the steel I believe where it will mostre the wonl. Sitage is a great deal cheaper than hay at \$15.th per ton. I think I savid the price of my silo this winter. My nfighlor: thomght I was razy for paying so much for a silo but they hitie come to the conclusion that they are alright. Yours respectfully, JOHN W. MATHES,

Bondurant. Iowa. 


\section{SILOS AND THEIR PROFITS.}

\section{Indiana Silo Co., ANderson, Ind,}

Gentlemen:-Silos have been in use in Europe and America many years, but did not come into general use in this locality until about ten years ago. Few falmers at that time knew what a silo was or what silage was used for. It was about this time that I with a few other neigh'or farmers was attracted by the Indiana Silo, and was induced to buy one, and accordingly the first carload was shipped to our county.

I erected it that fall on a circular concrete foundation near the barn, (should have been in the barn). It took four men about a day to put it up and put the hoops on and then we were ready to fill it. Using an ordinaly Ohio cutting box, with blower, I use my own cutter and engine, and it never has cost me over 50 or 60 cents per ton to fill. I can grow the corn and put it in the silo for that.

Now it is to the men who do not have silos that I wish to talk,they think they camnot afford the expense, when it is in fact, laying down one dollar and picking up two almost immediately, for the full

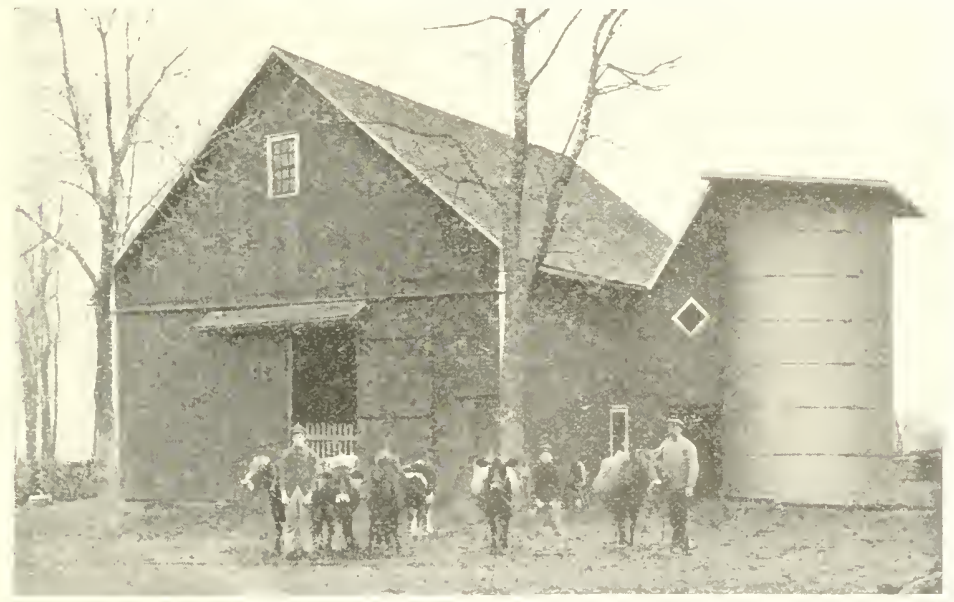

O. A. Morris \& Sons and Some of Their Dairy Cows.

cost of building the silo will be returned promptly the first winter, and again each succeeding winter. It is no longer an experiment, but a solid and seftled fact from the actual experience of thousands of practical dairymen and cattle feeders, that the use of the silo is both economy and convenience, and I cannot see why so many farmers hesitate to build them. Sell a cow or two or a steer if there is no other way to obtain the means.

It was not until the silo came into use in this meighborhood that the feeding of cattle was made profitable, while now I know a number of famers who do not like dairying, feed a bunch or two of cattle each winter at a good profit, each feedel giving the credit to the use of silage, it being succulent. It is next to nature's food (grass), it is an appetizer and a conditioner.

Now there is no reason why the average farmer of the Middle West cannot, or ought not to have a silo on his farm, whether he is in 
the dairy business or raising steers and sheep, in tact, it is good for any animal on tile farm and it will thive much better for having it than any other feed you can give it.

Of material for construction of silos we have brick, cement and wood. Of the three materials, wood is the best for the reason it is air tight and that is the secret of success in the use of the silo. A good silo bujlt as the Indiana Silo is built will last a lifetime if put under shelter and hold as much feed as a large barn.

Ifre is the sum and substance of the jrofits derived from the use of thr Indiana Silo:

1. If produces fat more cheaply than does dry food.

2. kusilage lieels young stock thilty and growing all winter.

3. Ensiage is more conveniently liandlea than dry fodder.

4. It enables dairy cows to produce milis and butter more economically.

5. It makes steer feeding profitable where corn is high priced.

6. There are no aggratrating corn stalks in the manure when silage is fed.

7. It is the most economical method of supplying food that is succulent (next to grass) for the stock during the winter.

In conclusion allow me to say that it behooves every farmer to look into the silo question and study it intelligently and you will agree witlı me that it is one of the most necessary adjuncts on the farm.

\section{O.A.MORRIS,}

Salent, Ind.

\section{GOOD FOR MAN AND BEAST.}

IndianA Silo Co, ANDERSon, Ind.

Gentlemen:-Your letter received and to the contest I would say that our silo was a great comfort to us as well as to our herd.

We think it is one of the greatest flesh, as well as milk producers. Oul cows did better while the silo feed lasted. The only trouble with us was there was not enough of the feed to last all through the season.

In the first place we did not get our silo up in time and the frost bit the corn, but all the feed was just the best. We aje very well satisfied and would recommend the silo business to any farmer who wants to feed good feed to make his stock get fat and look nice.

Hoping this may meet with your approval, I am, yours truly,

MRS. G. MI. IVILSON,

R F. D. No. 9,

Springfield, Ohio.

\section{FAT HEIFER PREFERS ENSILAGE TO CORN.}

INDiNA Silo Co., Anderson, Ind.

Gentlemen:- Aftel using my silo I bought of you last fall I am glad your agent insisted on mo buying one. I find it a great saving in feed. I led twelve hear of rattle and will have feed until the last of May. I have a 12x24 silo. I fattened a two-year-old heifer on ensilage this winter. I broke up corn anil put in the ensilage and she would eat the ensilage and leave the corn. My neighbor helped me butcher her. He said she was the lattest animal he evel saw. She was fed on silo feed and timothy hay. I realize I saved $\$ 92.00$ and have feed in the barn nice and warm. Yours respectfully,

WM. F. WOOLARD,

R. F. D. No, 6, Newark, Ohio. 
Indiana Silo Co., ANDERson, Ind.

Gentlemen:-Three years ago I purchased a 150-ton silo from you. Up to that time my farm of 115 acres maintained fifteen head of cattle and two head of horses.

Since building the silo I have been able by its use to keep fortyfive head of cattle on my farm the year round and two horses no more ground, no more feed raised, but the corn goes three times farther by means of a silo, because all of the stock, from close to the ground, all of the blades, husk and cob as well as the grain is saved and used, nothing at all wasted, all eat up by the cattle. Everything in the stock line on the farm eats it, the chickens, hogs, the boys' Billy Goat, horses, cattle, cows anil calves,-I have even seen the dog eating at the ensi!age

Thus, the silo together with the gas engine and ensilage cutter, which cost me near $\$ 600.00$ is worth more in earning power by the way

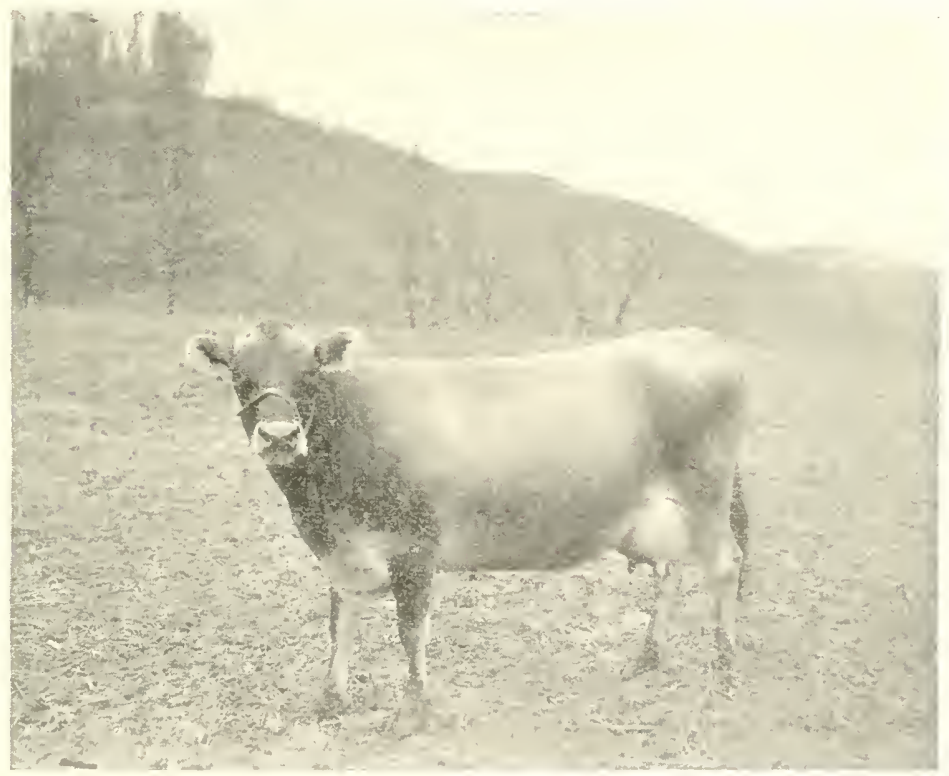

One of P. D. Morris' Money Makers.

of profits than $m y$ farm which cost me without these improvements, $\$ 5,000.00$, because the silo together with engine and ensilage cutter, enables me to keep 45 head of cattle and two horses instead of 15 head and two horses.

The fact outlined will be verified by me and in addition can furnish several of my neighbors who will do the same. My wife was opposed to me building the silo but you could not trade her another farm like the one I have for the silo, engine and ensilage cutter, should you bind her to do without the silo, and I feel the same way myself. 
You can put this together as you see best if the same will be of any service

I herewith enclose you the interior view of the stable. I have a picture of all buildings and silo together with stock and self, but I do not think it would suit as well as some pictures I have seen. Yours iluly,

P. D. MORRIS,

Jersey Heights Dairy,

New Martinsville, IV. Va.

\section{SHEEP EAT IT GREEDILY.}

Inllaxi Silo Co., Anderson, Ind.

The eagernt:s with which farmels will take up with some "Gold Brirk" or "Something for Nothing" scheme, and the indifference shown toward a high class proposition is surprising.

For instance, the "silo," so seldom seen, in fact is in most sections conspicuous by its absence.

A few years ago after considering the question at some length, and becoming convinced that I could no longer get along without a silo I took the mattel of purchasing up with several companies and soon hecame convinced that the Indiana was far and away a ove its competitor:, a supremacy it yet maintains.

The first fall the silo was filled from a field of corn that, owing to adverse conditions in planting time and throughout the season, was very small and late, wou'd not have reached maturity. There were 15 acres that would have husked about 300 bushels of corn at $35 \mathrm{c}$ per bushe?, which would equal $\$ 105.00$ estimated. The same when ensiloed made about 100 tons very good ensilage at $\$ 2.50$ would equal $\$ 250.00$. It cost $\$, 50$ to harvest and run in silo. The expense to harvest, i. e., cut and husk. either by hand or with husker, is practically the same as to run into silo, with the advantage in favor of the silo, as the days are longer, ground in better condition, etc. Counting 350 shocks of fodder at 10 , twice their value in this case, and we have $\$ 105.00 \mathrm{col} n$, and $\$ 35.00$ fodder, making $\$ 140.00$ against $\$ 250.00$, value of ensilage, not counting its added value of one-third in the better and more thrifty condition of stock, convenience of feed and the practical elimination of waste.

Again. if we secure two tons of hay to the acre we are pretty well pleased, while with the silo it is no uncommon thing to secure 12 to 15 tons of bettel feed and stored in much smaller space. Land $\$ 100$ to $\$ 200$ an acre, and heing satisfied with two tons of feed when we had just as well have 12 tons. One acre of hay will winter two steers. One arre of coln silage will winter four steers, and much better. Whether in the case of steers or the dairy often a loss without ensilage is turnerl into a nice profit with ensilage, and we find that of all our stock the sheep are the most greedy and the saving of feed and the thrift of the flock likewise striking.

A user of elsilage needs to be careful of his statement or he is likely to be discredited. Some two yeals ago the president of the Indiana silo Company called on an old schoolmate of the writer and told such nonderful stories conceruing the silo that my friend turned him down. A few days afterward I came in contact with this friend and he asked me concerming ensilage. I told of my experience and at the two accounts, as it were, tallied loretty rosely, my friend bought an Indiana silo and is an entlusiastic arvocate of their use.

It is possible with thin cattle to effert a daily gain of five pounds ler head witl good ensilage sprimkled with mill ferd. This has actually hern done on a in-day feed to the writer's knowledge. Doubting Thomases fall in line (UNSIGNED) 


\section{LONG LIVE THE INDIANA SILO COMPANY.}

Indiaxa Silo Co., Anderson, Ind.

Gentlemen:- Ýours oi $1,28,1910$, has been receiverl and contents noted. In reply I will iry to give you a few facts and figures as to what my silo has done for me in saving and utilizing feed.

First I will give you the cost of filling my 60 ton silo which holds 6 to 10 acres of com. I have fillel it with 6 acres and 1 have taken as high as 10, averaging 8 acres. First I will give you a statement of the actual cost of filling as follows: I am now estimating our average crop at 40 bushels per acre counting 18 shocks of 14 hill corn to the acre:

Engine and cutter, 2oc per ton.............\$1200

18 hands, $3 / 4$ lay at rate ol $\$ 1.50$ per day........20 2.5

4 teams, $3 / 4$ day at rate of $\$ 1.50$ per day .........6 600

Board of 18 hands, each 2 meals at $1623 \mathrm{c}$ a meal... 600

Total for filling..................... $\$ 1425$

I will now give you a statement as to the cost of liandling this $S$ acre crop as we formerly did:

Cutting 144 shocks at $8 c$ per shock................ 52

Husking 21/2 $\mathrm{c}$ per bul, 10 per shock, $14 t$ sliocks... 14 th

Hauling and cribbing corn, 90e per acre......... 720

Hauling fodder, $\$ 1.50$ per acre, 8 acres......... 1200

Total cost of haudling.............. 4 t5 12

I will now try to give you my experience in feeding silage in comparison with the old method. First I can increase the number of my cattle 40 per cent, from 5 to 7 , and bring them out in the spring in better condition than I could the lesser number on the same feed used under the old method of feeding. I find my cows give much larger quantities of milk when fed silage than the oid system and make butter of fine flavor and first class quality. I also feed my horses, brood sows and chickens silage.

It has a laxative influence and keeps them in fine conditon. Brood sows will suckle mole liberally. Chickens will lay more eggs (which is quite an item now). Another important item with me is the great advantage of having your leed converted into available manure of fine quality, at once ready to haul to the field and receive the benefit of it for the spring crop. I consider tbis a big feather in the silage cap. Another item of money saving is in utilizing the whole stalk, which is a bulky feed and stock will not eat near so much hay or fodder as if fed under the old system. I have almost enough hay every winter to pay for my silo over and ahove what we formerly dicl before we used the sta!k.

Another great advantage in preparing your coln in the form of silage is that you can get youl crop off the ground in time for seeding wheat. Still another, your field is clear of the troublesome shocks to worli around.

Our ground is all disked and drilled evenly all over the same, no lapping of seed, no spots whicls are not seeded left for weeds to grow. Another important and money saving item is in the destruction of the wheat and grass crop by driving over it in hauling the corn and fodder off. I consider the lamsge at a low estimate to be two bushels of wheat per acre. In addition to that the exposure of man and team through rain, hail, snow and cold wind digging the fodder loose the damage is incalcula'le.

I guess I have gone beyond the limit. It may go, let the results be what they will. I am not near done telling the advantages of a silo. 
1 look back with fond recollections when James L. Hill and my son called at my home and sold me a silo. When I was in my 76 th year I fed 25 cattle, four horses and a small bunch of hogs. The convenience of a silo enabled me to do it all myself.

Long live the Indiana Silo. Yours truly,

$$
\text { JOHN A. IICLELLAND, }
$$

Laurelville, Ohio.

\section{WOULDN'T TAKE $\$ 1,000$ FOR IT AND DO WITHOUT.}

\section{Indina Sho Co., Axuerson, Ind.}

I built an Indiano Silo in September, 1909, put in six acres of corn which I value at $\$ 30.00$ an acle amounting to $\$ 180.00$. The cost of filling amounted to $\$ 25.00$ and 1 fed $S$ ton of hay amounting to $\$ 56.00$. That fed 19 liead of cows from November 1st till May 1st. Half of these cows were giving milk and the cream in six months amounted to $\$ 570.00$, calves $\$ 25.01 \%$, whole amount $\$ 595.00$. The expense of filling and value of corn and hay was $\$ 261.00$, leaving me a net profit of $\$ 334.00$. Some of these cows which are dry, having been milked all

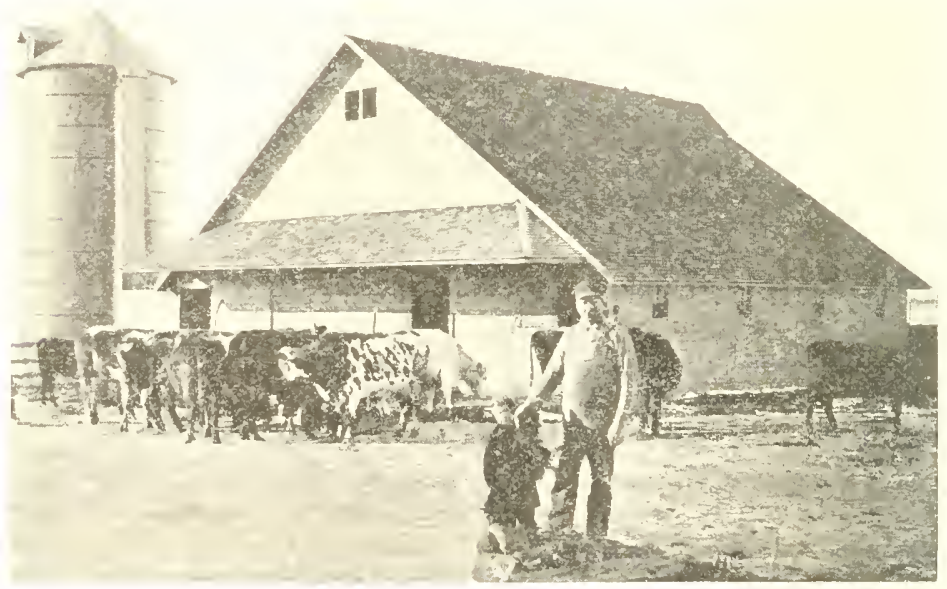

John A. Miller's Barn and Silo, lowa City, Ia.

winter and al'e now fat for butchering, have been offered $4 \frac{1}{2} \mathrm{c}$ for them. If I did not have a silo I would have fed 20 ton of hay, 300 bushels of coln and four tons of bran, amounting to $\$ 160.00$, leaving me a net profit of $\$ 199.00$. Making that corn worth $\$ 63.00$ an acle by the use of a silo. The profit of the use of a silo pays for it in one year.

I would not take $\$ 1,000.00$ for $m y$ silo and sign a contract not to build another one or to feed from another one. Therefore. I believe a farmer cannot invest his money to more profit than to build an Indiana Silo.

Hoping there will be many Indiana Silos built this year, I am. Ioul's tiuly, JOHN A. MILLER, Iowa rity, Jowa 


\section{MAGRUDER BROS. GIVE FIGURES.}

INdiana Silo Co, Anterson, Ind.

Gentlemen:-lu giving you the result of our first year's experience in using the $14 \times 30$ Fir stave silo we bought of you last year will say this silo was erected by our farm force, assisted in part by a carpenter 70 years of age. Fverything went together nicely. We filled the siln with yellow corn. Well dented, the last week in August, the ensilage keeping well and was fed as follows, except about 20 tons still on hand, and as it did not seem practical to buy cattle to use this feed we covered it with wet straw well paclied and will carry it to next season. 1909 , Oct. 22, bought 27 cattle, $23,310 \mathrm{lbs}$. at $\$ 4.10 \ldots \$ 95571$ Nov. 8, bought 15 catlle, 13,925 lbs. at $\$ 4.15 \ldots \ldots \ldots 577 \$ 8$

27 cattle on grass 30 days at .03 per head per day ...\$ 2430 $\$ 1,655 \quad 39$ 15 cattle on srass 15 days at .03 per head per day.. 675 180 shocks cut fodder at $10 \mathrm{c}$ (no demand for it).... 1800 3 tous hay (sceond growth orchard grass)........ 1800 82 bu. cob meal (coin cost 55c delivered)........ 4920 5,400 lbs. cotton seed mieal at $\$ 32.00$, cost delivered. $\quad 8640$ 65 tons corn ensilage at $\$ 3.00 \ldots \ldots \ldots \ldots \ldots \ldots \ldots \ldots . \ldots \ldots$

Com. driving and lottage on 42 cattle......... 43 40 Feed at Stock Yards................... 27 sn

Feb. 5, 1910, sold 21 cattle, 22,300 lbs at $51 / 4$ c.......... $\$ 1,17075$ Feb. 19, 1910, sold 21 cattle, 19,860 Ibs. at $51 / 4{ }^{\circ} \ldots \ldots \ldots \ldots \ldots 1,04265$

Balance

18916 100 loads of manure in barn at $\$ 1.00$ per load 10000

Total balance

$\$ 28916$

Ensilage made n' corn yieldiug 45 bur per acre or niue tons ensilage. It was our aim to make feeders of the cattle, not butchers. Yours very truly, MAGRUDER BROS.

Goshen, Ky

\section{BELIEVES SILO WORTH 40 ACRES OF LAND.}

INDIANA Silo Co., ANDERSON, IND.

Gentlemen:-1 put "1, one of yoml $12 \times 24$ Yellow Pine Silos in the fall of 1907. We commenced to feed silage December 6 th and fed 8 two-year-old steers and 24 head of cows and young cattle till the first of May with only silage, oat straw ard fodder and then fed the $S$ steers silage on clover pasture till the $10 \mathrm{th}$ of July and sold them for $51 / 2 \mathrm{C}$ per pound. They averaged 1.433 and made ns a good profit.

Last year owing to the drouth our corn did not go in in as good condition and we did not get as good results but we wintered 30 head of cattle and got them out on pasture in sood shape and we hope to do better this year. Will say that in our experience we consider a good silo equal to 40 acres of land added to any well regulated farm. Yours very truly, 
INDIANA SILO Co., AxDERSON, INo.

Gentlemen:-I purchased from you last fall an Indiana Silo, 20x36, and filled it with com and Soy Beans. This makes splendid feed for all kinds of stock.

1 have been feeding silage to from 75 to 100 head of cattle since December 3, 1:111\%. The silo has saved me $\$ 100.00$ jer month, so it will

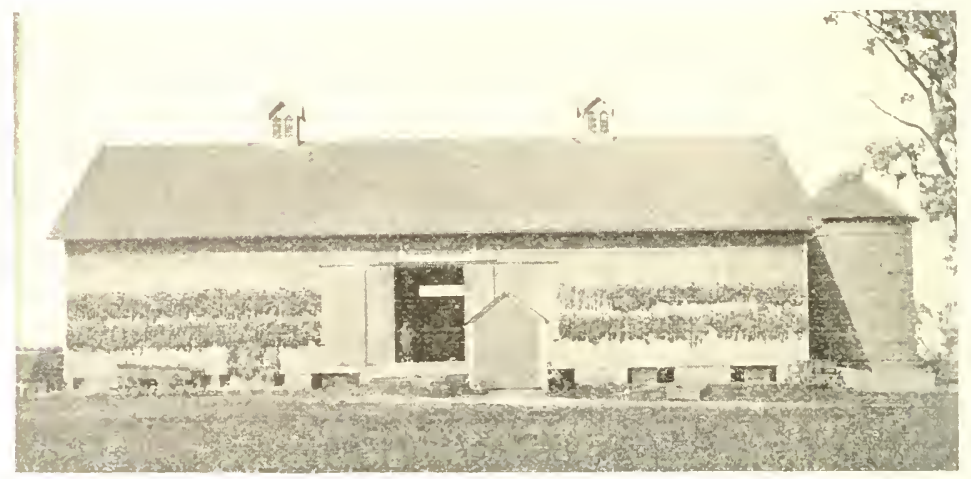

Mr. Merry's Barn and Silo. Hebron, III.

not owe me anything when it is time to turn the stock out. I shall have another silo alter a little and it will be an Indiana Silo.

1 tnclose you a photo of my barn and silo, also one of 20 two-year. olls which are just treshening now. Yours respectfuly,

M. IV. MERRY.

Hebron, Ill.

\section{MAY BUILD TWO MORE SILOS.}

IvDI I A SH, Co., Axnerson, IxD.

Gentlemen:-l have been feeding cattle for over thirty years. I nostly ted them on corn and hay alone. Of recent years I have been feteing cotton seed meal or cake along with the corn with better success, but last year I put uj one of your silos, $18 x 36$, as an experiment. I fed my cattie on ensilage alone for a while until I got them fully used to it. I then weighed them and ted them on $1-5$ of a bushel of corn a day along with the ensilage for thirty-three days and weighed them agair: and found that they had ganed 94 lins. per steer, a trifle less than thres pornds per day. I fed my calves on ensilage alone and they are lat, so tat that I am atmost persuaded to market them, although I did not intend to do so as I wanted to kerp them over as I always have done.

I am thinling of putting up two more silos this year as I am more than pleased with my experiment. I have never fed cattle with as little cost and as great gain in all my experience. Yous truly,

GEO. W. WVITT,

Kane, Illinois. 


\section{UNCLE DAN'S OPINION.}

Indiana Silo Co., Anderson, Ind.

Gentiemen:-I have made my calculation on feeding silage in dollars and cents, outside of the fodder and hay that I fed in connection with silage, which would amount to $\$ 20.00$. This amount I credited to 25 pigs that follow the cattle. This statement is the feed value of a silo to me.

80 ton silo.

8 acres corn, 12 tons per acre, 96 tons.

$\$ 20.00$ per acre, $\$ 160.00$.

$61 / 2$ acres fill silo.

$1 \frac{1}{2}$ refills atter setting three days.

$\$ 2.00$ cost of silage per ton.

Silo feed to calves, average weight of calves 300 to 350 pounds, average cost of calves $\$ 12.00$. Number of calves to consume 80 tons silage in 200 dars at 20 pounds per day to calf, it would take 40 calves, at a cost of 2 cents a day to consume the 80 tous of silage in 200 days, at a cost of 60 cents per month and make an average of 500 poinds, the selling price $\$ 25.00$ a head.

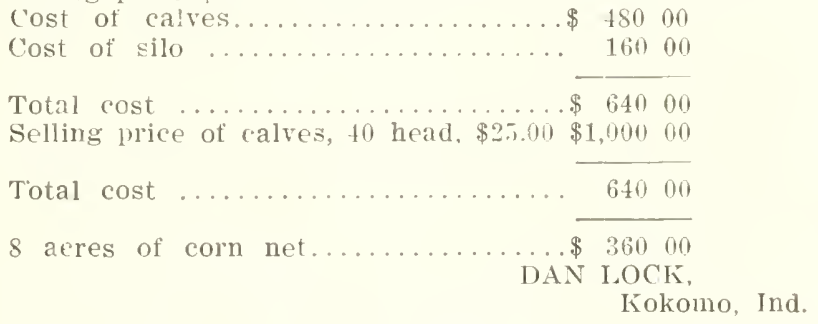

SAW THE LIGHT AFTER TWELVE YEARS.

Indiana Silo Co., Anderson, Ind.

Gentlemen:-I want to wite to you about the silo I got last year from the Indiana Silo Company. I am well pleased with the silo. I only feel sorly that I didn't get a silo ten or twelve years ago. I would have macie more money out of my milch cows because it saves so much more other feed and they give so much more milk by feeding silage than they do by feeding other feed. There is no better investment made than to put up a silo on a farm. Even if I had only 3 or 4 cows I would put up a silo. Yours respectfully,

H. I. MEYER,

Watseka, Ill.

\section{BETTER THAN GROUND FEED.}

Gentlemen:-Replying to yours of the 3rd inst., will say that we commenced feeding from our Indiana Silo built last fall on Jan 1st. Have fed 18 cows on silage and a little clover hay. Have, also, fed some to the horses and young stock.

We have a feed mill, but have not ground any grain this winter. Our cows have done rathel better than othel winters when we fed them liberally on ground feed.

We consequently feel more than satisfied with our investment in the silo. Yours truly,

G. P. MERTEN \& SON.

Garner City, Pa. 


\section{COWS INCREASE ONE-HALF.}

Indina Silo Co., Anderson, Ind.

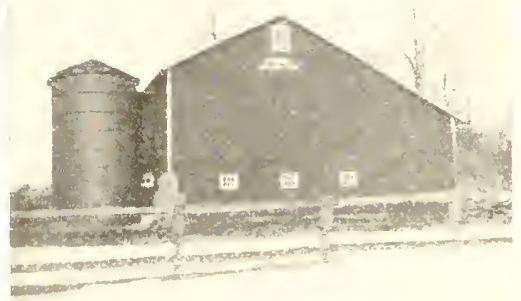

O. D. Mourer's Barn and Silo, Greenville, Pa.
Gentlemen:-I am today sending you a picture of my barn and silo which I received of you in 1907. The same went together in good shape and I must say that it is the best money maker I have on the farm, The silo is $14 \times 24$ feet and will run ten to twelve cows. My cows are in better shape than when I had no silo. Will say that it will pay any man who has only a few cows to put up an Indiana silo. My cows make one-half more since I have a silo than they did before. Yours respectfully,

O. D. MOURER, Greenville, $\mathrm{Pa}$.

\section{DON'T HAVE TO WORK IN RAIN.}

INDIANA SHLO Co., ANDERSON, IND.

Gentlemell:- Aftel two years experience of using the Indiana Silo and after studying on improvements of it the same length of time found this imposible camse. It is and must be successful. It is hard to give exact figures to show the profits by the use of a silo because it is not only the waste of leed you are saving but it also means saving worli, especially in mean and rough weather to haul in the feed, and another thing, all your stock-ffed, bran, etc., is all unnecessary by the use of a silo, so each one can about judge himself what he would save by using one.

Everylody can do without one the way I did but no longer after he has had one. After the first one would be ruined for him by a fire In two weeks if possible he would have the second one on the road.

I am very well pleased with mine and so is everybody else who has one I am safe to say. I close, respecting you.

IIENRY MONKE.

Mt. Olive, Ill.

\section{TEXAS HEARD FROM.}

IYDIAYA SIIO (\%, ANDERSON, IND.

(ient? nevel heen fuld and the reasrn is this. You have grefn feed as good as the liest grass, and any time of the year you want it, and when the grass is good and plentiful let your ensilage stand until the grass is gone and you can go back to the silo and it is as good as ever. The Taft Dairy has been rumning for about three years and since the use of a silo the jurofits have been large, but before, it no more than paid expenses.

I will try and send you a photo of my bann, silo and dairy herd. Yours truly, H. H. MITLER, Mer. 


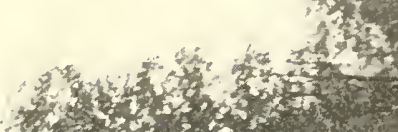

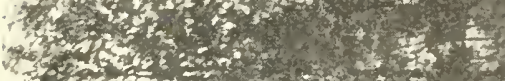

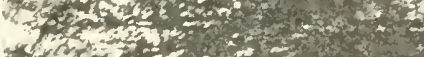

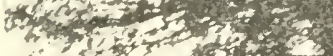

$\therefore$ ats

$y^{2}-x^{2}+20$

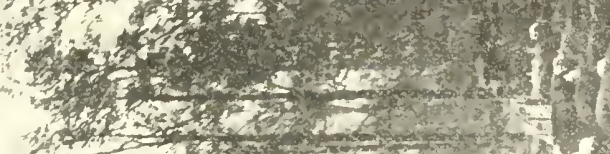

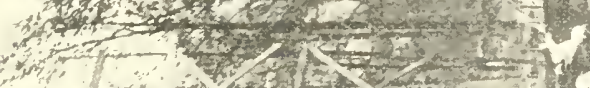

how

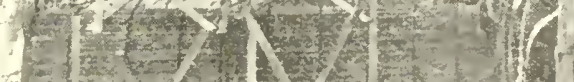

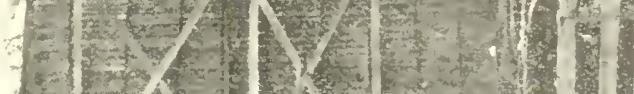

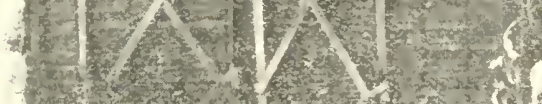

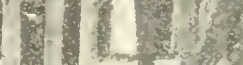

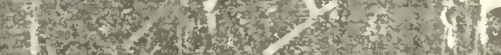

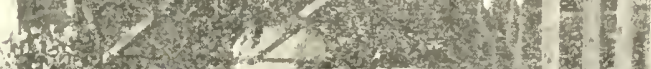

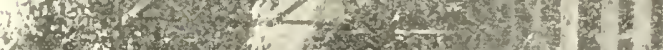

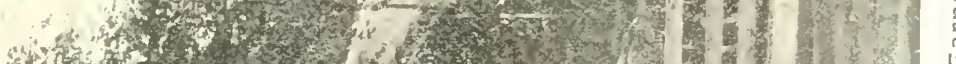

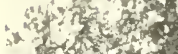

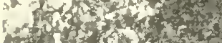

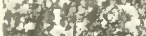

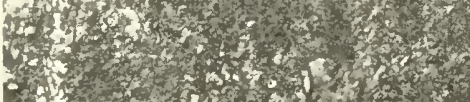

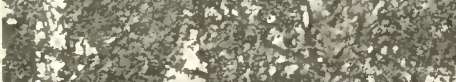

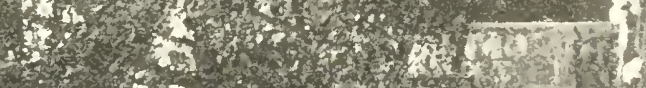

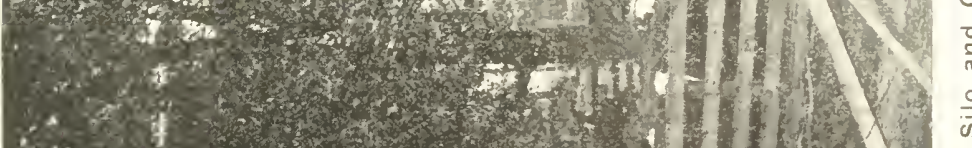

क

ง

$\leftrightarrow$

$\frac{\frac{1}{2}}{\frac{c}{2}}$

0

$J$

$\frac{\Phi}{2}$

山

$\frac{3}{3}$

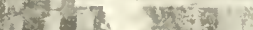

$\frac{0}{ \pm}$

苾

0

옫

음
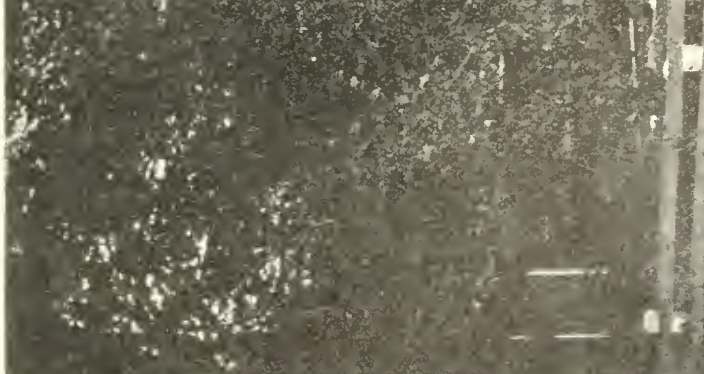


\section{DIDN'T THINK IT WOULD DO FOR STEERS BUT MADE $\$ 2,783.00$ SPITE OF IT.}

IndIANA Silo Co,, ANDERSON, IND.

Gentlemen:-l have made cattle feeding a business for fourteen years but never until the past winter used a silo. I thought ensilage would do for dairy cattle but not for fattening cattle until your Mr. Foster of Carmel, Ind, a personal friend, convinced me I was wrong. I now wish to give you a few figures.

Oct. $13,1309,1$ bought 73 head of cattle in Kansas City, averaging 1,062 lbs., at $\$ 5.10$ per cwt., at a cost of $\$ 3,9 \$ 5.95$. They were turned on grass 18 days, then fed corn and fodder 38 days. They ate 30 lbs. of coln priece each day and gained $1 \frac{1}{2} \mathrm{lbs}$. per day. Dec. 8th I began to feed $30 \mathrm{lbs}$. of ensilage per head, with 9 lbs. of ground corn, and 4 lbs. of clover hay. This we continued 114 days and 2 lbs. per day was the gain. After the ensilage was all gone they only gained $1 \mathrm{lb}$. per day on 30 lbs. of col'n with 11 lbs. of hay. I saved 1,800 bu. of corn by using ensilage.

These cattle were shipped to the Chicago market on April 27, 1910. They averaged 1,360 lbs. and brought $\$ \$ .10$, or $\$ 8,041.68$. After counting a fair market price for all the feed these cattle and the hogs which rali with them have eatell, I bava a net profit of $\$ 2,783.00$. To say I am well pleased with the result is putting it lightly. I will put up another Indiana Silo this year. Yours truly,

\section{[T. G. MICHENER.}

Noblesville, Ind.

\section{SAVES FROZEN CORN.}

Indiana Silo Co., ANDERson, IND.

fintemen:- Two years ago last fall we lumbhased a silo of your company. The first fall we filled it with corn that was hurt some by frost and we found it was a little too green. When we got about four or fire feet of the bottom it seemed io be too sour. The cows did not like it so well. The next fall we filled it when the corn was just right. The cows relished it much better. We have a balf Jersey cow that has given 45 to 52 pounds of milk a day. She was fresh. Tanuary 8,1909 , and harl milk fever. We sent, for a veterinarian, Dr. F. Miller of Fort kecovery, onic. He said when he got hore that he wondered what woull cause milk fever that time of year, but when he got in sight of ond darm hr saw the silo and then he knew what caused it. He said not to feer a row ensilage for ahout ten days before reshening, when they give much milk, for ensilage made milk about the same as good lastule. She wals fresh again this winter and she got along alright.

This fall mv last planting of coln was late and it was killed by frost, hut we let it stand until it got dry enough to put in the silo. It niale as good ensilige as wo had last year. We give our cows all the frsilige they will eat up clean. I don't know how we could get along without a silo especially for our milk cows. We feed our horses silage, too, two brood mares and our young horses and they seem to do well on it. I think it gives them an appetite.

IVe have never kelt an accomnt of the profits off of our cows, but last vear our cows averaged us a little over $\$ \$ 1.00$ apiece. They are just grade Jerseys. Our cream goes to the creamery.

we have not much to say but what we say is the truth. Yours truly,

D. F. MILLER, New Weston, Ohio. 


\section{DOESN'T NEED BUTTER COLOR.}

Indiana Silo Co., Anderson, Ind.

Gentlemen:-I bought a silo from the Indiana Silo Company in the year of 1907 . It is $14 \times 24$, the only place l could buy the staves that Tong in one piece. The Company furnished me good material and filled their contract satisiactolily in every way.

I filled the silo the same fall and fed the ensilage that winter and was surpriser at the results in several ways.

First, the cattle ate it up clean, which is not the case with dry corn fodder. I shred my fodder and the stock leave a third of it, while the same lind of zoln put in the silo in a green state is eaten up clean and I get at the lowest estimate one-third more milk from the same amount of coln fodder fed in the old way.

Secord, it is succulent feed, equal to grass or any food in a green state and you have this green food at your command in the winter months when it is impossible to obtain such food.

rinird, my butter in the winter is that yellow color, such as ve get when stock is turned on grass in the spring. I never use butter color.

Fourth, I can feed so many more head of stock from fewer acres of land.

Another advantage of silo filling with green corn is I have longer days and warmer weather and can get hands to fill the silo before the corn is ripe enough to cut up and then the corn is removed and the land is ready to plow much earlier than the old way of handling the crop. I have been using the Indiana Silo for three years and would not winter stock again without one.

I kept an account of what my cows made during the winter of 1909 and found the eight cows averaged fifty pounds of butter a week and I only fed 500 pounds of bran with the ensilage.

Before I used the silo the eight cows did not average twenty pounds of butter a week during the winter months.

My advice to farmel's keeping stock is to build a silo for the winter of 1910 and if they want the staves in one piece order from the Indiana Silo Company.

S. M. ZINK,

Christiansburg, Va.

\section{SILO MADE FARM EARN \$64.90 PER ACRE.}

\section{Indiana Silo Co.. Anderson. Ind}

Gentlemen:- In answel to yours of the 11 th will say I think the Indiana Silo which I have filled now for the thild season in succession cannot be beat. The winner of 1908 and 1909 , getting $\$ 1.70 \mathrm{per}^{\circ}$ hundred for my milk, I realized $\$ 64.98$ per acre fol $\mathrm{my}$ corn, hesides the milk and butter I used for my family of six. I am beating that quite a bit this winter but cannot tell in exact figures until the silo is empty. The silo opens up fine with only a little waste on top. Ny cattle come through in good condition. I can keep more cattle on the same number of acres as there is no waste in the silage. The cows relish it and eat it up clean. I feed clover hay for roughage and a little oil meal. I do not envy the neighbor's their job of digging forlder from under the snow. It is wolth money to have our feed handy and ready to feed and will say your silo is a good silo both in material and workmanship, and only the best is good enough for the dairyman and farmer.

Wishing you success, I remain. Yours truly, 
INDIANA SILO Cu., ANDERSON, IND.

Gentlemen:-1 will give my last year's results of dry corn fodder and my first 100 tons of Indiana silage.

The winter of 68.09 the average number of gallons of milk raised from 25 milking cows was $601 / 2$ gallons per day. Ration, dry fodder, hay, brewery grains, 250 lbs, of No. 1 white middlings. In '09-'10 the average tor milk to April $1 \mathrm{st}$, is $66 \frac{1}{2}$ gallons from 25 cows. Ration, Indiana Silage, hay, brewery grains, 200 llss, of No. 1 white middlings. Results: Better milk, more of it, and better looking herd.

Six gallons of milk profit, at $21 \mathrm{c} \ldots \ldots \ldots \ldots \ldots \ldots \ldots \ldots \ldots \ldots \ldots$ Fifty pounds middlings profit, at $\$ 34.00 \ldots \ldots \ldots \ldots \ldots \ldots \ldots$

Protits each day from Nov. $1,09 \ldots \ldots \ldots \ldots \ldots \ldots \ldots \ldots \ldots$ Nov. 1, '09 to April 1, '10-150 days-amounts to . . . . . . \$316 50

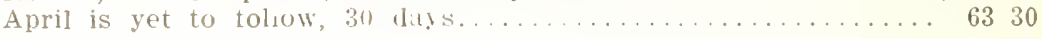

Gain of '09-10 over 'os-s $(09 \ldots \ldots \ldots \ldots \ldots \ldots \ldots \ldots \ldots \ldots \ldots \ldots$ Cost of silo, concrete bottom and roof...............\$300 00 Gain first year $\$ 79.80$, one Cypress silo userl one year.

Why do I use an Indiana Silo? Because it keeps silage perfectly with its air tight seif draining mortised joints, and continuous wood door frame and ladder combined, there is nothing to rot. 'That is why I bought an Indiana. The Indiana Silo was, also, the cheapest of six other makes wt considered. Isn't that what the stockraiser, dairyman is looking for.

What does it cost to fill a silo? Not a cent more than dry curing fodder. We hired an ontfit blower and engine, had $71 / 2$ acres of corn out, sowed one businel and peck to the acre, cut it with hand. It took four men two days, had three teams, two of our own, two men in field, one at machine, two in silo. So it takes four men the two days you are cutting and seven men when filling.

T. MENZIES,

Irwin, $\mathrm{Pa}$.

\section{SILO PAYS 64 PER CENT NET ON INVESTMENT.}

lvina Silo Co., Anmirson, IND.

Gentlemen:-I bought an Indiana Si o in the summer of 1908 , a $12 \times 30$, and cost me complete, ioundation and roof, $\$ 210.00$.

I filled it with $51 / 2$ acres of corn, and with the addition of 10 acres of corn fodder worth $\$ 4.50 \mathrm{por}$ acre or $\$ 45.00$, and 3 tons of bran worth $\$ 26.00$ per ton, or $\$ 78.00$, I fed eight head of cows and twelve head of young cattle, from the 15th of October to the 15 th of March, and have enougl ensilage to last to the first of June. I have sold $\$ 150$ worth of cream per day lrom the cows, or $\$ 225.00$ worth, and my young cattle have gained $\$ 15.0()$ per head, or $\$ 180.00$, which makes a total income of $\$ 405.00$ for five montlis. Deducting the cost of bran and fodder from $\$ 405.00-\$ 123.00-\$ 2 \$ 2.100$, tor $2-3$ of the feed put in the silo, or an entire fefing value of $\$ 423.00$. or $\$ 77.00$ ver acre for corn used in filling.

The corn used would have made 75 bushels per acre, worth $52 \mathrm{c}$ leer bu., or $\$ 39.00$ per acre, and fodder worth $\$ 4.50$ per acre, makes $\$ 43.50$ per acre, or $\$ 239.25$ for the $51 / 2$ acres, which leaves a balance in favor of the silo of $\$ 1 \$ 3.75$, or 87 per cent on the investment. But the fepding value of the corn may be $20 \mathrm{per}$ cent more than the market value, so we will give it that, or $\$ 297.10$. Still the silo paid 64 per cent on the investment.

WM. W. LEMERT,

Napoleon, Ohio. 
Indiana Silo Co., Anderson, Ind.

Gentlemen:- We have been feeding ensilage for tour years. We are highly pleased with the feed. We can't praise the silo we bought of you too highly. We don't see how we got along before we got the silo of you. We wouldn't have the silo taken out of the barn and bind us to not put up another silo for five times what it cost. We have been feeding twenty-five head of cattle and colts seven months every year since we got the silo. We keep the manure spreader running nearly all the time.

Now our silo is in the barn in the middle bent. The barn is ninety feet long, seven bents, three drive ways crossways of barn, We want another silo to keep more stock, to buy more land, to keep more stock, to make more manure, to raise more corn, to feed more stock, to make more money, to buy more land, to raise more corn, to feed more stock, to make more manure.

I can't send you a picture now. Will send one as soon as I can. Yours respectfully,

EDWARD McPHEETERS

Fredericksburg, Ind.

\section{PUTS IN POOR CORN.}

Indiaxa Silo Co., Anderson, Ind.

Gentlemen:-Yours of the 19th received and coutents noted. In reply will say that 1 put up an Indiana Si.o last fall. It is $16 \times 20$ feet and rated at 80 tons. We filled it within six inches of the top, putting in 14 acres, or 322 shocks of corn. The coln was very poor, owing to the dry weather and judging it from the rest of the field which we husked the silo contained 450 bushels. Counting this at $60 \mathrm{c}$ per bushel makes $\$ 270.00$ worth of corn. The fodder would have been dear at $4 \mathrm{c}$ a shock but at that it was worth $\$ 12.8$ s. Thus, the silo contained $\$ 282.88$ worth of corn.

On November 8 th we opened it finding the silage had only spoiled about six inches on the top. We began feeding twelve head of cattle that averaged 861 pounds a head. They were fed all they would eat of the ensilage together with a little clover hay and about 20 shocks of little corn until the 5th of February when they weighed 1,065 pounds a head, a gain of a little more than 2 lbs. a day. These cattle had no shelter except the straw stack and wind brake. They were never under a roof while we had them and last winter was the coldest for years.

After they were sold we still had a door and a half of silage left, so on February 21st we bought $\&$ yearlings that averaged $675 \mathrm{lbs}$. We will have enough feed to run them till grass comes. In addition to this we have fed three milch cows, three fall calves and 40 ewes this winter besides giving a little to the horses, hogs and chickens.

In regard to actual profits in dollars and cents so much depends on prices that I can hardly say what our profits were. We sold during the drop in prices owing to the boycott. If we had kept the cattle 30 days longer I could have sold them for $\$ 6.00$ per cwt. They cost $\$ 4.75$. Then at a gain of 2 lbs. per day they would have sold for $\$ 400.85$ more than they cost. Remember the silo only contained $\$ 282.88$ worth of corn to start with. Is it necessary to say any more?

I could write a volume on the benefits derived from the silo but lack of space forbids. Yours truly,

PAUL, MONSER. 


\section{A CLEAR GAIN OF $\$ 150$ A YEAR.}

INDIANA Silo Co, Axuerson, IND.

Gentlemen:- In accordance with your letter received, a silo is worth a good many dollars. Silo.

The best investment a farmer can make is by buying an Indiana

It should be one of the first buildings a farmer puts up.

Then the farmer cau keep more stock.

When I did not have a silo I had six head of cattle. I have now twelve head and next year will have four more. As near as I can figure every foot in depth of my silage is worth at any rate $\$ 10.00$. The more stock you have the more money you take in and the only way to farm is to have an Indiana Silo. Last smmmer as it was so dry my pasture was short. I had silage left and was glad I had it for that kept up the llow of milk. If I had not had it l would have been $\$ 100.00$ out. Ever since I got my silo I gain every year. I would not farm without a silo. I can't see into it how some farmers get along without one. I can't. Tou'd not sell mine.

As I got my silo three years ago and could keep more stock I made a clear gain of $\$ 150.00$ a year. Yours truly,

\section{HENRY BUNZOW,}

Two Rivers, Wis.

\section{SILO IN IOWA SAVED NEARLY TWICE ITS COST IN ONE YEAR.}

\section{IXD1AxA SHe Co., Axmersox, IND.}

Gentlumen:- l figure ny silage cost me $\$ 2.50$ per ton put in the silo. Twenty dollars ler acre for corn in the field and $\$ 40.00$ for labor putting it in the silo. It took 18 aeres to fill my 120 -ton silo, making the total cost \$sm.no, and I fed 44 head. Started in to feed silage the 10 th day of November and have enongh to feed until the middle of May. T'he cattle comsist of 18 milch cows, one bull, 7 two-year old heifers and 18 talt calver.

W\% fed the rots and mill to promuls per head a day at $11_{\text {it }} \mathrm{c}$ a pound equals ir per head The seven heifers 34 l's at $1 \frac{1}{4} \mathrm{c}$ equals $33 / 4 \mathrm{c}$ bet heat. The 18 calves, so lbs at $1 \frac{1}{4} \mathrm{c}$, equals $10 \mathrm{c}$ for the 18 hord. In addition to the cow feed we fed them one pound cotton sered moal. The meal cost per day for cows was $2{ }_{2}^{1} \mathrm{c}$ a pound, or $45 \mathrm{c}$ a day for the 1S. We didn't feed any hay but kept a rack of straw in the yard for them to mun to when we let them out, so you see by the above figmes it cost me $4 \frac{1}{4} \mathrm{c}$ per head a day. On the average my cows have dous tine on milk all winter and the calves will do for veal. In fact, the farmel's think that they suck the cows.

I womld recommend a silo to all men. My silo has paid big returns on the investment.

Thuse figures refresent what my silo cost me. The silo completed, founclation and root, $\$ 300.00$. I broke 41$) 15$ acres of hay ground for corn and would have had to cut and shock 25 acres of corn for dry feed, making a total of forty acres. Now then it only took 13 acres to fill the silo, so I saved 27 acres of corn that meant 40 bushels to the acre which equals 1,0.80 bushels at $50 \mathrm{c}$ per busiel, making $\$ 540.00$. By taking the cost of my silos away from it I have $\$ 240.00$ to the good. Isn't that enough in favor of the silo, and I doubt if the 15 acres of hay and 25. cut dry fodder would have fed my herd of cattle, so you see it cost me about ic a head per day including straw. 


\section{ROUND SILO AS COMPARED TO SQUARE.}

Ixdiaxa Silo Co., Axpersox, Ixin.

Gentlemen:- In the summer of 1895 we built in our barn a square silo that we used until two years ago, when we bought a $14 \times 21$ foot Indiana Silo of Yellow Pine. Will say that the using of that antiquated square silo, with its unfavorable losses, proved profitable to us, but vastly more profitable do we find using our Indiana Silo without any loss. Our 1895 silo was the first one ever seen here at that time and our neighbors coming to see the ensilage would say: "Well, sauerkraut is alright enough at times but not for every meal," and thought stock, too, wou'd get awful tired eating this kind of 'sauelkraut, as they called the ensilage, but soon had cause to change their minds after seeing how our stock thrived on it, and that we were not so much out of our minds after all. Now, right here, let us with emphasis say, that in our opinion from experience, no farmer, especially with a vely small larm, should be without a silo and the Indiana Silo at that. A farmer without. a silo cannot carry much stock or feed at a profit. A two hundred dollar barn with a silo is as great or better than a six hundred dollar barn with no silo attached, in our opinion. The silo barn is not crowded with fodder and corn, has more room for stock. Can always feed in barn every day, regardless of weather.

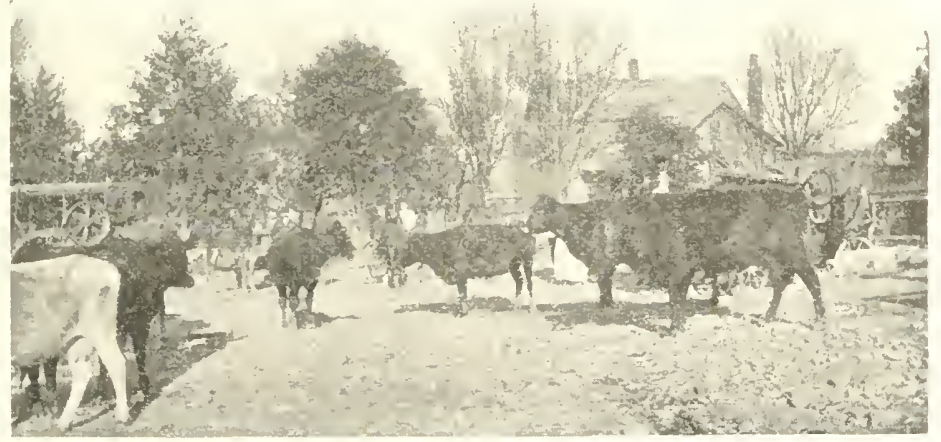

Summit Farm, Crouch \& Pumphrey, Bethel, Ohio.

This year we opened our silo about the 10th of November last and found the ensilage fine and now arn feeding 35 hoad of steers, 6 head of cattle (4 horses and a span of large mules), 50 large sheep, on ensilage and have 13 hogs running among the cattle doing well. We expect to place all this stock in the market by the middle of April fat and at a good margin in our favor.

As you see, we are not confining ourselves to any one specialty in feeding, but promiscuous stock feeding with very satisfactory results. The silo we bought of you is proving first class in every respect as to material and workmanship.

Enclosed you will find a photo of some of the barn yard at our farm. We will say our rough feed consists of fodder and shredded fodder. Yours respectfully,

CROTCH \& PUMPHREY, Summit Farm, Bethel. Ohio. 
Indiana Silo Co., Anderson, Ind.

Gentlemen:-Yours at hand. I have been using one of your silos for three years. Would say that I would not be without one if I would want to keep and raise stock. As I am a dairyman my cows give a good flow of milk even at zero temperature. As the silage is a succulent food the cows relish it and will eat a good bit of hay or other dry feed which they would not do if it was not for the silage and the more a dairy cow eats the better she will do at the milk pail and the better she fills the pail the better she fills the dairyman's pocketbook.

I bought a silo of your company in 1907. I have found it very economical feed the first. winter I used the silage. The summer of 1908 was very dry and the months of August, September and October were so dry that we did not get any fall pasture. I had a good supply of hay but no pastule in the fall. I had to feed some hay early in order to keep the cows in milk. I waited for rain and the rain did not come, but the silo man came along about the first of September and stopped at my falm and wanted to sell me a silo. I told him I had one and did not want another. He said it was always easier for him to sell a silo to a man that had one than to a man that had none.

\section{The Silo Paid for Itself the First Winter.}

I ordered the second silo from that man. I had enough corn to fill both of them that fall and some left and I know that if I had not built the second silo I would have had to buy more hay that winter to carry my stock through the winter than the silo cost me the first year and it is good for many years to come.

About the Indiana Silo I will say this, that the one stave silo is the only silo for me as the silage is good from the top to the bottom. There is no leakage at any place as the stave runs the full height of the silo, but the short stave silo has some faults.

Where the staves are joined they will leak more or less. Mine does and I have a good bit of spoiled silage along the sides of the $K-$ silo, but in the Indiana. Silo I have no waste from top to bottom.

I have had some trouble in zero weather. The silage would freeze to the staves, which no one can prevent. I take a feed out of the silo the same as at any other time and if any is frozen to the staves I take the fork and pry it off the staves and throw it in the middle of the silo and cover it up with an old binder cover, and some old binder canvass. The frozen silage is all thawed out by the time I am ready to feed again. Furthermore, the cover will keep the silage from freezing. The steam of the silage will stick to the cover and make it air proof in cold weather and it is better for stock when it is warm in cold weather than when it is frozen. Do not cover it in warm weather.

As for economy in feeding corn fodder the silage is the only way the stock will eat it clean without any waste. Shredded fodder is good feed but I can't say how much feed there is in the fodder. I always had to clean the mangers when I fed shredded fodder, but when I feed silage my mangers are always clean. No natter how thick the corn stalks are there is never any left in the manger.

I am getting sleepy so I guess I will quit for this time. If my writing is ary good to you use it, if not you know what to do with it. Yours truly,

GEORGE LIEBO,

Peru, Indiana. 


\section{GRASS AND WEEDS AND A LITTLE CORN MAKE GOOD SILAGE.}

Indina Silo Co., Anubrison, Ino.

Gentlemen:-I am the first one to buy a silo of Lemay \& Bevis, your local agents at Newton, 11l. Also the first to come west of Newton, there being six others sold to be delivered at Newton. I bought a $12 \times 30$ silo in February. 1 planted 40 acres of land in corn from which

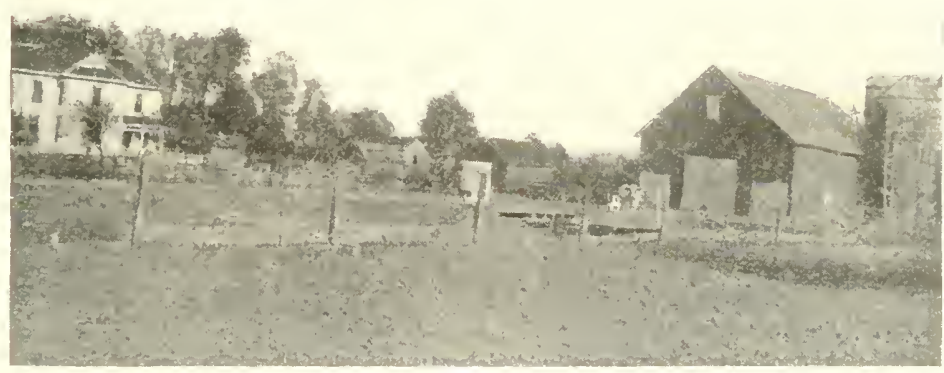

Farm Home of G. W. Corbin, Wheeler, IIs.

I expected to fill the silo, but did not raise 100 bushels on the 40 acres. My corn was planted on very low ground and I did not get to cultivate it, as it rained all through the plowing season. It was, in fact, the wettest year I have ever seen here, which time has been 40 years.

I had a fine crop of large thrilty crab-grass, some water grass and some few smart weeds, so I hardly knew what to do. I concluded as I had a silo that I would put the grass and weeds in my silo. I took my grain binder and bound the grass and weeds and a few scattering coin stalks on about 30 acres and cut it with an ensilage cutter and put it in the silo. I can say for a truth that there were not 50 bushels of corn all told put in silo.

I began to feed silage the 1 st of January to 25 head of cattle, 9 head of cows, 8 head of two year-old heifers and 8 head of yearlings. All but five of the cows had nothing but silage up to the 1st of April. I fed silage, also bran, oil meal and soy beans, to the five cows that were giving milk. As to the cattle other than milch cows I offered them a good grade of mixed hay (threshed) timothy and red top. They did not seem to care for the hay and would not eat it until they had eaten all of their silage, as I fed all together in a small manger. The cattle all seemed to relish the silage and it seemed to satisfy them. The result was that most of the cattle came through the winter in very good condition. I believe in better shape than if I had kept them on the hay which I offered them and was able to sell at $\$ 7.00$ per ton on the 1st of March. If I had sold the same hay one month earlier I could have sold it for $\$ \$ .00$ per ton. At $\$ 7.00$ per ton and 15 tons, which I helieve would be the amount that it would require to feed all the cattle the same length of time that I fed silage, saved $\$ 105.00$, with the cost of putting the grass in the silo, which would not be over $\$ 20.00$ outside of my own work. 
I don't consider the stuff I put in the silo worth anything, if it had not becn put ul, green, as 1 had all of the same kind of stuff left that I could use.

I draw a conclusion that if the kind of stuft that I put in my silo gave me good results, I believe that good corn silage would do better. Also that it will enable me to save some of my summer's work in case I do not have much but corn fodder or grass lor feed, as sometimes we Gy ont liere and also drown out, but nearly always make some fodder which is genera!ly not worth anything for feed after it is cured up as it does not mature when either too wet or too dry but if it can be put up green ir will make vely good feed.

It gor's without saying that I am so well pleased with my txperithe with my sijo that I have ordered another me of the same size and make to be put ul this summer. Yours truly,

$$
\begin{aligned}
& \text { G. II. CORBIN, } \\
& \text { Wheeler, Ill. }
\end{aligned}
$$

\section{AN OLD TIME WINTER.}

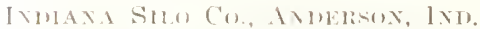

Crentlemen:- The real old lashion winter shows no signs of abatement. Shork corn that was scheduled to go through the

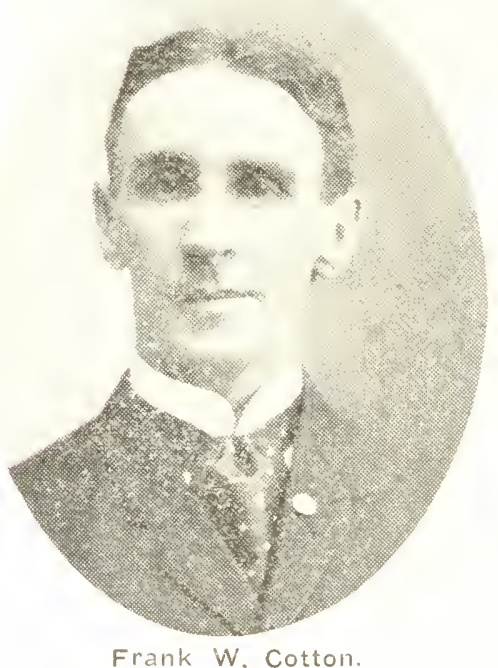
shredder is largely standing in the field.

Why not then put up a silo and avoid all this disagreeable work of digging out of the snow the noressary feed for the stock during the winter, With the silo you can vrepare your winter feed during the bright days of September and when driving snows and wind come your stock is in the barn eating silage and making good gains, while on the other hand if you depend on ('orn fodder you are compelled to haul it out of the snow and mind and scatter it about on the ground and while the stock are eating uly the feed that should be putting on pounds of flesh they are just getting enough to warm them up sufficiently to melt the snow on their backs. In this day of high priced feed tamers sliould do anything they can to grow a lot of it per acre. The only way to do this is hy preparing to feed more stock on less land. There is no way by which you can lo this so profitably as with a silo. Figure it yourselit in 111 acres of corn. In a silo you get 310 acres of feed at a cost of $\$ 4.13$ per acre with corn that will make 60 to 70 bushels of corn per acre, making 13 to 15 tons of fted per acre. Can you prelare your corn any other way so that you get as much in return to proportion to the cost of the feed?

FRANK IV. COTTON, Manilla, Ind.

Note-MIr. Cotton fed "John I. Sullivan," rhampion Shorthorn steer calf at Fat Stock Show. 


\section{SMALL SILO SAVED OVER $\$ 300$ FIRST YEAR.}

Indina Silo Co., ANmerson, Ind.

Gentlemen:--Your letter received. You wanted to know the actual results in dollars and cents by the use of the Indiana Si.o, will write as I find it so with mine.

I count it one of the largest money makers and money savers ever placed on a farm. In the summer of 1905 I had twenty-five acres of clover from which I harvested 40 tons of hay worth $\$ 7.00$ per ton, making $\$ 280.00$ and I paid out $\$ 17.00$ for harvest hands. I also cut up 200 shocks of corn and paid $6 \mathrm{c}$ per shock to have it cut up, making $\$ 12.00$. The fodder was worth 15 cents per shock, making $\$ 30.00$. I had 200 bushels of corn which was worth $50 \mathrm{c}$ per bushel, making $\$ 100.00$. Also, 100 bushels of oats worth $30 \mathrm{c}$ per bushel, making $\$ 30.00$, and two tons of bran worth $\$ 22.00$ per ton, making $\$ 44.00$. All this I fed that winter and besides I bought two tons of hay at $\$ 7.00$ per ton or $\$ 14.00$, making the cost and value of my feed $\$ 513.00$, which I fed to 25 head of cattle, 4 head of horses and twenty head of sheep.

In the fall of 1906 I purchased an Indiana Silo, 14x24 which cost $\$ 125.00$. I paid $\$ 25.00$ to have it put up, making the total cost $\$ 150.00$. I put seven acres of coln in it, which would average 50 bushels per acre and was worth 50c per bishel, making $\$ 175.00$. I raid out $\$ 12.00$ for hands to help fill silo. I cut up 100 shocks of coln, paid 7c per shock to have it cut, which is $\$ 7.00$. The value of the fodder was $15 \mathrm{c}$ per shock or $\$ 15.00$. All this making the cost and value of my feed in the winter of $1906, \$ 212.00$ and the cost of silo $\$ 162.00$, including help, building of, and the silo itself. I fed the same number of cattle, horses and sheep as the year before with just as good results and less wouk. Therefore, the cost of my feed in 1905 was $\$ 513.00$ and the cost of feed in $1906, \$ 212.00$, so I saved $\$ 301.00$ on feed the second year whon I fed silage.

I have had $m y$ silo four years and would rot do without it. This winter I am feeding 17 head of cows, 13 of which I an milking, and 9 head of young cattle, which I feed straw and silage and I feed my milk cows one pound of oil meal a day to each cow, with silage, and I also feed fodder once a day and I sell the cream. The 13 corrs average me $\$ 15$ per week, which is better than before I hall the silo and with less cost, and it not only saves money, but saves time. It does not take long to feed silage.

If you see fit to use this article do so, for I have given you the re. sults I have obtained by using the silage for feed. Yours very truly,

EDIVARD MORRISON,

Licerne, Ind.

\section{ONLY THE USER OF SILO CAN REALIZE ITS BENEFIT.}

Ixdiana Silo Co., Anlerson, Ind.

Gentlemen:-Aftel having used one of your silos for the past three years I desire to say that I legard it as tlie best paying investment I have made on oul farm. I am able to produce from its use more pounds at a less expense than by any other process of feeding I have employed. By the use of the silo I am able to get the glain cared for when the days are long and the weather is good, this being a feature that many farmers do not consider, but in my judgment it is a very important feature. The financial profit gained by the use of youl silo can only be imagined by the person who does not have one and only realized by its actual use. Very truly yours,

JAMES M. LARMORE,

Anderson, Ind. 


\section{WHY EVERY FARMER SHOULD HAVE A SILO.}

Indiana Silo Co., Anderson, Ind.

Gent?emen:-Hre is a statement of what the silo has done for me, this being the first year I have had it. In October I lought four head of cattle for $\$ 72.0^{\prime}$, fattened them and sold them in January for $\$ 125.00$. I sold 15 lbs. of hutter per weel at $28 \mathrm{c}$ while other years the cows stood dry. I also so'd 9 tons of hay at $\$ 14.00$ per ton, which otherwise I would have fed. I also fattened a nice barrel of pork with the milk. The silo has saved in all, this amount for us.

Thanks to the silo,-every farmer should have one.

Hoping this statement will be satisfactory to you and hoping to hear from you soon, I remain as ever. Yours truly,

JOE Le BRECK, Jr.,

Oconto, Wis.

\section{A GOOD COMPARISON.}

INDAxA SILO Co., ANuersox, IXI.

Gentlemell:- In August, 19us, we erected one of your 20x30-foot Jellow Pine lndiana silos. The first of December 70 head of feeding steers wie put in the barn and divided into four lots, two of 20 each and two of 15 each The ration of all of them consisted of ensilage, hay, shelled corn and cottonseed meal and was weighed and charged for at nurliet price by a representative of the Department of Agriculture at Washington. The results were very satisfactory, not only being greater, but were made at considerable saving as compared with the old way of feeding.

By comparing two lots of fifteen each with a similar lot of 30 head led on another farm on full dry ration, we found that the last men. tirmed had eaten three bushels more corn per day and also more hay and weighed 55 lbs. per head less than the cattle fed on ensilage, when sold. The cattle were all sold the same day and at the same price. By comparing results of the two lots of 30 head each we found that the 30 fed on ensilage made a net profit of $\$ 442.45$ over the others fed the old way.

The results of feeding ensilage were perfectly satisfactory, so much so that we erected two more of your Indiana Silos on our other farms ant are at this writing feeding 140 head on ensilage, shelled corn alle hay.

The logs are very fond of the ensilage and will follow along the trough when feeding the cattle and will pick up that which is dropped or falls out of the trough and do much better after silage fed cattle than alter dry fed cattle. Yours truly,

J. H. MILLER,

Yorktown, Indiana.

R. F. D. No 2 ,

\section{GOOD INVESTMENT; WILL BUY ANOTHER.}

Ixdmaxa Silo Co., Anderson, Ind.

Gentlemen:- I have one of yolir silos, have used it one year and think it one of the best investments on $m y$ farm for the money it cost me. Would not think of doing without a silo. Expect to have another one in the near future. Yours very truly, 


\section{KEEP COWS CHEAPER IN WINTER THAN SUMMER.}

Indaxa Silo Co., Anderson, Ind.

Gentlemen:-Received your letter and will say a few things in regard for a silo. We have been using an Indiana silo for three years and would not be without one. Before we had our silo we could only keep two cows where now we have twelve cows and six heifers for we only have a twenty acre farm. There was only one silo in our neigh. borhood of which the owner was called a fool, for people didn't know what a silo was, but when the saw how nany cows he liept and in such good condition the people thought the silo alright. Siuce then there have been about forty put up within about seven miles of 1 s, of which we were the third. Most all of these are the Indiana Silo, as they find them the most satisfactory and they are strongly built.

We have a feed mill, but have not ground any grain this winter.

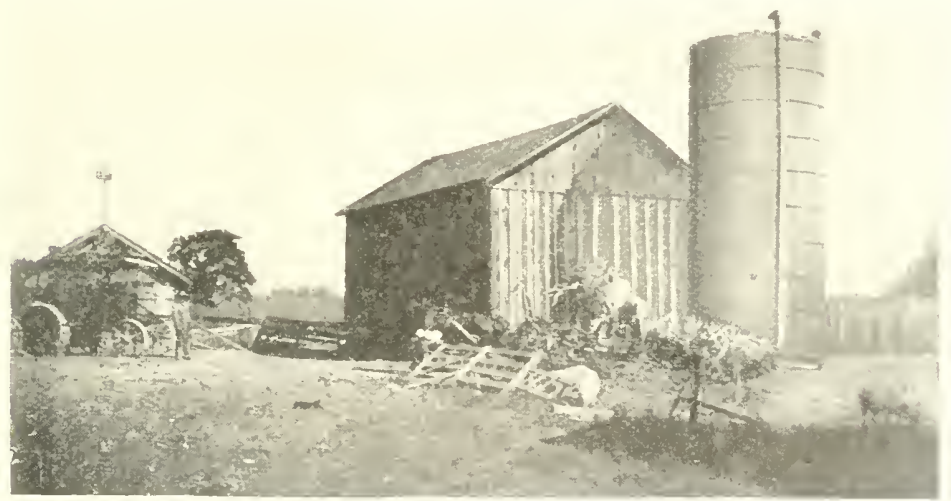

Silo and Barn of H. Lungmus, Hamlet, Ohio.

Our silo holds eighty tons, of which seven acres fill. We lieep our cows cheaper in winter than iu summer for in summer we rent our pasture five cents a cow a day. The man from whom we rent it has forty acres for them to roam over and in the winter we feed them the ensilage. We think in a year or two we will buy another one for summer use as it is cheaper. Every person can figure for himself the profit he makes by keeping a silo. It he has a silo he can keep more cows than befole, and if he keeps a dairy, and feeds ensilage his cows give more milk, so that's where the profit comes in by having a silo. Every man that keeps stock ought to have an Indiana Silo. A man goes alound in this neighborhood with his machine only charging twenty-five cents a ton for filling the silo. As for the other help, those of whom own a silo come and help and we help them back so we do not have to hire help.

Enclosed you will find a picture by which you will see our silo has not a roof as experience shows that ensilage keeps hetter without one. Yours truly,

H. LUNGMUS,

Hamlet, Ohio. 


\section{THE ACTUAL RESULTS OF A SILO.}

INDlANA Sulo Co., ANuElisox, InD.

Gentlemen:-Being a dairyman l speak from a martical experience on that line. The silo is indispremsable for that purpose. In some cases it saves a croy that would orherwise be lost. For instance, last year the season was extremeiy wer and I dirl not get to plant my eight acres of bottom land in corn until June 17th. The latter part of September 1 lut it into the silo, it being then in the roasting ear stage. I had one acre on a hill which was very ripe. I husked all of the ripe corn and cut the stovel and nixed it with the green bottom corn and had good si age. My green coln without a silo would have leen almost a total losin, as tile next week after filling the silo a heavy killing frost came which practically testroyed all green coln. In lans I husked so bushels
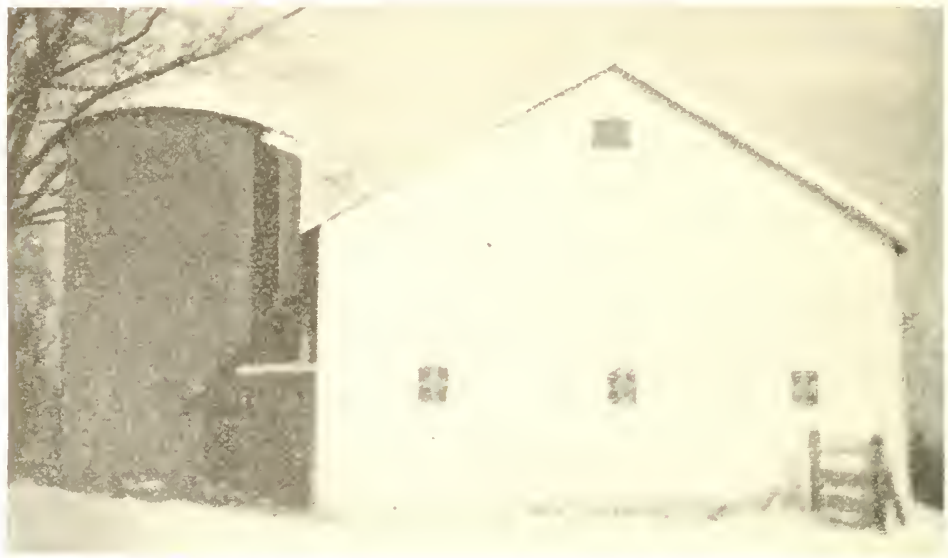

W. D. Clore's Silo, La Grange, Ky.

of corlu from s areses and let it dry on the groums. then hauled it in. Fed some to my stork hogs and crushed some amol fed to my cows. I put the romainder, including stover, jnto the silo which made good silage for cows. One ol the greatest advantages of the silo is that you can phast your conn lat" or early and market twothisds in roasting ears and put the remainder in the silo and have good silage, or you can plant sarty, husk one-half and put halance in silo and have silage for daily cows.

By the use of a silo I make from three to four times as much feed as I can other feerl on the same gromml. I have now 6.; or 70 tons of good silage which would have been almost destroyed by frost and worth mobably $\$ 30.00$. By feeding silage I make at least 20 per cent more milk. I3y selling two-thirds of the roasting ears I would realize about $\$ 30.00$ per acre and eight acres would amount to $\$ 240.00$ and have 60 of 70 tons of silage which will still make a valuable increase in milk.

Silage is good for almost anything on the farm, from chickens to horses. My cows and calves eat it more heartily than any other feed on the farm. I have a six weeks' old calf that eats it heartily. 
The silo is valuable for feeding beef cattle by putting all of the corn and stover in it.

These are only a few of the advantages of the silo. If a farmer wants to avoid the inclement weather and make his work a pleasure rather than a burden and save the expense of at least one hand in winter I advise him to invest a small sum in an Indiana Silo with the continuous door and $1 \mathrm{am}$ satisfied that he will be pleased and doubly paid. Respectfully,

W. D. CLORE,

Lagrallge, Ky.

\section{FEEDS SILAGE TO EVERYTHING.}

\section{Inthana Silo Co., Andersun, IND.}

Gentlemen-l have filled my silo three times and have found it to be a very beneficial store pit for feed for all kinds of stock and poultry.

My silo is 16x30 feet. Twelve acres of corn, producing 50 bushe.s to the acre will fill it. I am feeding 30 head of cattle, 10 of which are 2 and 3 years old. The two year olds are in good fiesh and the 3 year olds are also in good flesh and ready for pasture or market. They will weigh 1,475 pounds per lead, good for $\$ 6.00$ per $c w t$.

By feeding ensilage with straw and fodder seven cows will give $1 / 3$ more milk. I have 13 head ranging from 10 months to a year old and are in good flesh which I know is due to feeding ensilage. Twelve acres of corn cut and put in a silo is worth 36 acres of timathy hay.

In $1908 \mathrm{I}$ sold my cattle for $4 \frac{1}{2} \mathrm{c}$, in 1909 for $5 \% \mathrm{c}$. The cattle tliat I expect to sell in the spring will be worth lic.

We also liced our chickens ensilage and they are liealthy and in. crease the amount of eggs.

One call see by the use of a silo anyone can greatly improve the weight and quality of their steers.

By using straw for bedding I will make 45 loads of manure, (9) loads to the acre), will cover 5 acres which will yielı 20 bushels of corn more to the acre.

$20 \times 5-100$ busheis and at $50 \mathrm{c}$ per bu. will gain $\$ 50.00$ on 5 acres. As ever yours,

I. N. CLARY,

Incerne, Indiana.

\section{SILAGE IMPROVES APPETITE AND IMPROVES DIGESTION.}

Indiaxa Silo Co., Anderson, Ind.

Gentlemen:-I praise the silo very highly and fincl it to be one of the most beneficial factors of the farm. It can be filled when the weather is nice and warm and days are of good length and your ground is clean and nice for seeding,- loos not injure your gromur by hauling out the corn, -is the most economical way of handing the corn crop) at a small expense,--no waste of feed and a good bunch of feed always in the dry and handy and easy to leed. Ensilage is a feed on which cattle do well. It helps to give appetite, improves digestion and gives a good appearance to the cattle.

Nine acres of average com will fill a silo $14 \times 24$ and it will take three times nine acres of hay to take its place. A silo is the thing for a poor man as well as the man of wealth, also the small farm as well as the large farm. A man with 40 acres of land and a silo can kepp as many cattle as a man with 80 acres withollt the silo. Yours respectfully, LUYE J. CIARY, Lucerne, Indiana. 
Indaxa Silo Co, Aniflison, Ind.

Gentlemen:- Six years ago I was living on a rented farm in Lake County, Indiana. I was paying big cash rent. Light crops that year made me wonder how I was going to get through, make the rent, and live. Thera was a large square silo on the plice. I had not used it before because there was 110 machine in the surrouzding country to fill it with, so I bought one and filled the silo, which was quite old. We put in about twenty. five acros of short, but fairly well eared corn. We fed that feed as a whole feed except oat straw, which was fed in a feed-rack. No other grain or hay was fed to forty head of cows and I sold $\$ 1,065.00$ worth of milk. While it lasted the cows were slick but run down a little in flesh. The milk was good. We filled the silo the next year but fed dry grain and hay with it. which J think is better as silo feed is not a balanced ration alone.

We then moved to Porter Connty and did not have a silo the first year. It seemed as if we could hardly get enough feed from one hun. dred and sixty acres to feed twenty-five cows. The next year 1 got an Indiana Silo. I wintered 48 head of stock that year, 30 cows, 10 head of youns cattle and 8 horses and had about 15 ton of hay to sell. The next year about the same.

In the year of 1909 we sold $\$ 300.00$ worth of hay and we will have mlenty to feed 30 cows, 11 head of young cattle and 9 horses, 50 head in all. We find we can make a gain of two cans of millk a day ( 8 gallon cans) from 30 cows, over what we can make on dry feed. We feed three peclis of silo feed to a cow twice a day, and about half as much grain as we do on dry hay. We feed hay two or three times a week after they have eaten their silo feed. The cows are fat and slick and they shed their hail four to six weeks earlier than they do on dry feed. I think we will double the production of the farm in a few years with the help of the silo and the cows. The silo is the salvation of the dairy or stock man. It saves feed, makes summer conditions in winter, makes the cows glad and pays the dairyman 100 per cent.

\section{H. F. CAREY,}

Valparaiso, Indiana.

\section{BETTER HAVE CORN IN SILO THAN OUT IN SNOW.}

Indaxa Sito Co., Anderson, Ind.

Gentlemen:- In answer to your letter will say as I have no scales, I can't furnish you weights.

But I don't need scales to see what my silo has done for me.

For the last three years I have had nearly the same amount of stock. I always fed everything that looked like feed in shape of roughness, besides as much grain as I put in my silo this year. This year I have a'ready sold $\$ 128.00$ worth of hay and still have a good supply on hand, with twenty acres of stalks scarcely touched and silage enough to last till grass is knee high, and my cattle are at least worth $\$ 5.00$ a head more as when I used the starvation plan. To say nothing of the three months strictly cold and bad weather this winter.

As to the cost of filling the silo I consider it cheaper than digging fodder out of the snow all winter. Cost of silo is about the same as a barn that would shelter the same amount of feed.

My silo is $16 \times 30$. We filled it with eleven acres of corn in $1 \frac{1}{2}$ days.

I am truly thankful for your square dealing. Yours truly, 


\section{SILO SAVED OVER $\$ 300$ IN FIVE MONTHS.}

Indiana Silo Co., Anderson, Ind.

Gentlemen:- In regard to your silo I will say I would not think of keeping stock without one, after using yours for the past five months. I cannot say enough for the silo.

I put four acres of corn in it. I have kept six cows for five months almost entirely on ensilage, have not given them two tons of hay,- - four of the cows giving milk for which I have received $\$ 183.52$. I have saved at the lowest five tons of hay at $\$ 15.00$ per ton and $\$ 50.00$ on sugar feed. Total saved on feed and milk \$308.52. The cost of filling silo, rent of land and care of corn $\$ 50.00$. I figure that the milk used in the house and manure made will pay for the care of the six cows for the five months or a profit from the six cows of $\$ 258.52$. Yours for the silo,

ALVIN CHURCH,

Poplar Grove, Ill.

\section{SILO MADE FARM PAY FOR THE FIRST TIME.}

Indiana Silo Co., Anderson, Ind.

Gentlemen:-We are so well pleased with the silo which we purchased from your agent last fall that we feel it our duty to write you concerning same.

We filled the silo chuck full (125 tons) from 15 acres of silo corn and legan to feed the silage on November 1 st and have fed from same every day since, this makes five full winter months' feed for 25 cows, 4 yearling beifers and a large bull. The only feed used in addition was two tons of bran and what fodder the cattle would eat when turned out in the feed lot and we still have 10 or 12 tons of this silage left which we are feeding. We have milked from these cows on an average of 50 gallons of milk per day and are selling same in Columbus, O., at 20c per gallon. In other words the money invested in your silo has paid us the largest return of any investment we have ever made on the farm and we would not do without it if it would actually cost us five times the purchase price.

The only regret is that we did not purchase the silo sooner as this is the first year that the farm itself has been a paying investment. Yours very truly,

THE CAPITOL DAIRY FARM CO.

J. H. METCALF, Pres.,

Columbus, $\mathrm{O}$.

\section{THE SILO AND A RETAIL DAIRY MAN.}

Ixmand Silo Co., Anderson, IND.

Gentlemen:-Answering yours of the 19th inst. would say that our experience from the use of the Indiana silo dates back to the fall of 1907 and it has been more than satisfactory and highly profitable to us.

We were in the retail milk business then and our books show following local conditions and the handsome profit we saved to start in with:

Sept, 1907.-Clover hay not to be had. Corn very scarce and high. Timothy hay held at $\$ 1 \$ .00$. Without a silo we required not less than forty-five tons of hay to carry us to grass. A grajn ration to balance the timothy easily ran our feed lill up to more than what our mills would sell for.

45 tons hay at $\$ 1800 \ldots \ldots \ldots \ldots \ldots$ 
With ensilage we used 12 tons for noon feed; 12 tons at $\$ 18.00 \ldots 21600$ Coln to fill silo, $12 \times 30 \ldots \ldots \ldots \ldots \ldots \ldots \ldots \ldots \ldots \ldots \ldots \ldots \ldots$

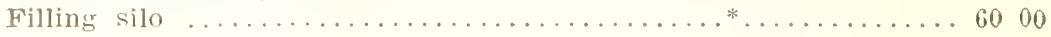

$\$ 45600$

$\$ 351.00$ saved to stalt in with and with the savings we are able to make on om grain rations, we paid for the silo and made fair wages for our winter's work. Without the silo we would have run heavily behing and our hours of raw-hiding a thankee job.

Some of our fresh cows on ensilage produced milk for several

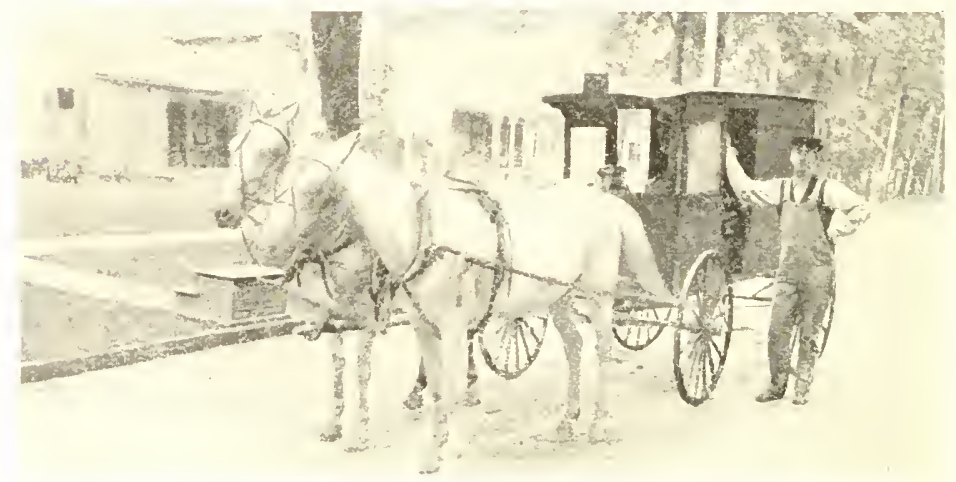

T. H. Case's Delivery Wagon and Team, New London, 0 .

weeks tor : of a cent a quart. We firmì beileve every dairyman should lave ( 2 ) silos, one for winter and one for summer use.

While ensilage is very lrofitable as a winter feed it surely brings in a balvest in the summer in connection with the pasture. Our books sliow that in June and July of 1909 we sold $\$ 570.00$ worth of milk and cleam. We proiluced $\$ 600.00$ worth but our trade was somewhat irregular.

Cost of same:

12 toll ensilage at $\$ 2.00 \ldots \ldots \ldots \$ 2+00$

Grain lation for Jume.......... 2000

(irain ration for Jisly........ 3000

$\$ 7+00$

Wh carried from 18 to 24 head and sold milk at 5 cents in summer () pnsilage lan low in July, thus extra expense for grain.

Many of onl batrons had very queer ideas as to what a silo was and what the feed would do. We had numerous requests not to use the prilage as if rould taint the milk and ruin our business. One kind oll lady saju, "Mrr. Case, don't you tever feed 'silos' to your cows. My folks feil them when l was a girl and nearly killed the whole herd and they afterwarls grew all over the farm."

Gents, if you have that variety in stock now, kindly pass the seed this way.

In conclusion wish to say that we never had nicer milk than when feuding (nsilage and our greatest trouble was in keeping pace with a growing business. Yours.

CASE \& CASE, Per T. H. Case, New London, Ohin 
INDiAxA Silo Co., Axderson, IND.

Gentlemen:-My experience in my first year with my silo:

In the spring of 1908 I bought of your agent a Cypress Silo, 16x30 feet, cost $\$ 350.00$ set up. In September I put in 10 acres of small corn estimated at 10 bushels an acre, dry year, poor coln.

I bought 30 cattle in Chicago, weighing 22,270 lis., cost laid down at home $\$ 779.23$. Opened silo Jan. 1, '09. At that time the silage had settled to 12 teet deep. Fed silage night and morning with some poor hay and some fodder. The bunch of steers ran to a straw stack and had a shed for shelter if they chose to go in. Silage gave out in Alpil and was compeled to finisl to time of hlue grass with hay and forler. Here is where I lost corm at $80 \mathrm{c}$. I decided not to risk it. If I had had silage my cattle would have brought $6 \mathrm{c}$ in June. So'd cattle last July at $\$ 5.10$.

30 cattle brought $\$ 1,4 \$ 4.75$.

30 cattle cost $\$ 779.23$.

17 tons hay cost $\$ 70.00$.

Total cost of cattle and hay $\$ \$ 19.23$.

Total profit $\$ 635.52$.

Had my corn grown as in an ordinary year I would have had 25 feet of silage instead of 12 feet and have fed on and sold my cattle in June at $6 c$, and made $\$ 300.00$ more money and had left on farm a straw stack and my hay and fodder in manure pile that covered 8 acres of tabacco ground. You know what that means at $10 \mathrm{c}$ tobacco.

I am satisfied ny silo paid more than half of its cost in saving of feed after allowing for bad corn crop. Had I luad it full of silage it would have paid for itself the first winter.

No person can do without a silo if he has stock, if he is compelled to borrow money to get it.

The corn as fed is Cut, shocked, husked and cooked the day it is put in silo,- - silage is the sanre as coolied feed. Yours very truly.

CLARENCE CHILDS.

West Middletown, Ohio.

\section{ENDEAVOR TO PRODUCE MOST AT LEAST HARM TO SOIL.}

INDIAxA Silo Co., Axpersox, IND.

Gentlemen:-Yours of the 24 th nlt, at hand, in which you ask for statement showing profits from use of silo and offering cash prize for" best article. Also all the articles in book folm sent to each contestant.

Neither my experience nor ability would justify me in attempting to be a prize wimner but write to secure the experiencs of others. My use of a silo is limited to the past winter and is about as follows:

My corm was hard hit by hail, almost all the blades were off and the grain did not mature so that it was badly damaged for feed or market. I filled my silo from the worst piece, do not think the conn worth more than $\$ 60$ cash, expense of filling $\$ 12.50$. I liegan feeding December 1st. Fed 10 head straight and have enough to last until June 1st. Also fed a few sheep and also find it a natural food for them. $I$ gave my horses some this spring and find they leave their shredded fodder readily for it. As my cows were to freshen early I did not try to greatly increase their flow of milk but just wintered on ensilage without grain or other feed. This I do not reconmend, yet my cows came through in good shape and are milking freely since freshening. They do not show that gaunt, restless disposition with a desire to quit. 
their feed at the first appearance of grass which we used to so much dread.

I also think it is the best chance for wheat we have as the corn comes off in good time and there is no more tramping.

This is my experience in short. I have no doubt but that with better ensilage I shall like it still better. At present I would not think of doing without a silo. As guardians of the soil T think our aim should be to produce the most feer with the least possible liarm to the ground and one way is to nse an Indiana Silo. Yours respectfully,

L.EWV CIIAMBERLAIN,

Sheridan, Indiana.

\section{ENSILAGE FED AND ALMOST TWICE THE GAIN.}

Inmana Silo Co., Avierson, Ind.

Gentlemen:- There are three main reasons why the Indiana Silo which has been in use on my farm four years, has been a paying lupposition to me, viz:

(1) It is built of the best material and is, therefore, the most durable.

(2) It is the most economical way of preparing succulent feeds.

(3) It is a paying investment to me because it makes more profits than any other manner of feeding.

To explain the first reason I can say from my own experience that there are no decayed parts, no broken joints, no broken hoops, the dool's fit perfectly and l have had no expense for repairs.

To explain No. ? I use my silo for fattening cattle. I have an ensilage ('utter for four farms which cost me $\$ 125.00$. I hire an engineer and engine for $\$ 1.00 \mathrm{per}^{2}$ day, use three men in the field for cutting, two for loading, one for feeding cutter, one for tramping in silo and foul teams. In $21 \%$ days' we had filled the silo, using ten acres ol colll and have one hundred tons of feed, at a total cost, except (utt:1 of $\$ 66.25$, teams $\$ 3.00$ and men $\$ 1.50$ per day. Another advantage in putting up feed in this way, it is earlier in the season, the days are longer and you ciu get more work done for the same amount of money. Tlinn you have ten acres of corn that is out of the way and the land is realy for early seeding. Now if we had cut this corn, 250 shocks at eight cents a shork, $\$ 20.00$; shucking 750 bushels at five cents, $\$ 37.50$; hanling fodder, $\$ 22.50$; making a total of $\$ 92.00$. Therefore, I saved $\$ 25.75$ on havesting the crop besides these other advantages. You can see that in this way an Indiana Silo will soon pay for itself.

In the 3 rd to show the profits from ensilage feeding I will give some comparisons from my cattle feeding: I have 22 yearlings in one pell that wet no ensilage, and 100 head of calves that get ensilage. Now during the perior Dec. 10, 1909, to Jan. 7, 1910, I will give the amount of feed each bunch received and what they weighed. The yearlings got as their daily ration per head, $101.5 \mathrm{lbs}$. of shelled corn, 7 lbs, of clover hay, 1 lb. of cotton seed meal. They weighed on Dec. 10th, 736 l' $^{3}$ s. per head. On Jan. 7th they weighed 778 lbs, per head. Making an average daily gain of $11 \frac{2}{2}$ lbs. per head.

The 100 calves zot as their daily ration per head, $10 \mathrm{lbs}$, of ensilage, 5 lbs. of clover hay, 5 lbs. of shelled coln, 1/2 lb. of cotton seed meal.

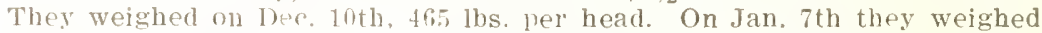
535 lhs. per head, making an average daily gain of $21 \frac{1}{2}$ lbs. per head. So taking into consideration the gain made by the bunch fed ensilage and the ain made by the bunch not fed ensilage, I think there is no better way of feeding cattle than to have an indiana silo.

OSCAR .J. CITRRENT,

Redkey, Ind. 


\section{SILO INCREASED MILK PRODUCTION $36^{3} 4$ PER CENT.}

\section{Inniana Silo Co., Anderson, IND.}

Gentlemen:-Yours of the 26th leceived and I herewith write you the results I obtained the first year by the use of an Indiana Silo.

I erected an Indiana Silo in August, 1908, size $16 \times 30$, capacity 120 tons, which I filled in September, same year, off of 10 acres of land at a cost, including the rent of land, of $\$ 6.00$ per acre; cost of tending same, filling the silo and for planting and all expenses ready to feed, $\$ 1.40$ per ton. I opened the silo on November 15th, 1908, and fed $3^{0}$ head of cattle, including young stock, until May 11th, 1909, and had enough left to feed 18 head of milch cows during a part of August and September during a very severe drought.

On December 1st, 1907, I began to weigh the milk flom each cow every day as she became fresh,both night and morning,and have continued to do so ever since. I find that the same coirs with the same grain ration and for the same number of months made a gain in the milk production of $1,318 \mathrm{lbs}$ each, or $363 / 4$ per cent, and a gain in money for milk sold of

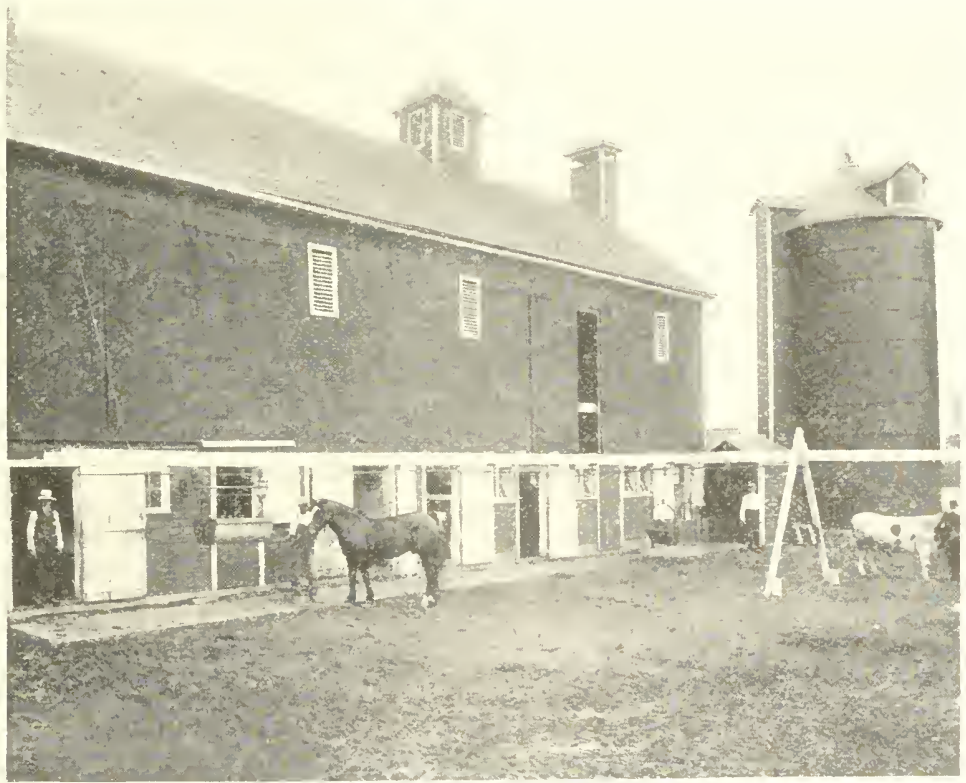

Indiana Silo on Oak Dale Stock Farm, Dixon, Ill. Observe Results Obtained and Compare With Your Own.

$\$ 17.40$ each. I am satisfied that the benefits of feeding ensilage does not end with the feeding of the coms that are fresh during the winter months as all my winter herd was never in se good condition when turned out to pasture and my whole herd made a gain of $958 \mathrm{lbs}$, of milk each on an average in 1909 over 1908, the year before I erected the silo. My herd's average ploduction of milk in 1909 was 7,220 lbs. and the average amount received for milk from each cow was $\$ 86.77$ and the average cost for keuping each cow was $\$ 48.07$, net receipts from each cow were $\$ 3 \$ .70$. 
The average percentage of butter fat was 3.78 . The amount received for every dollar expended for feed was $\$ 1.801 / 2$.

You may draw your own conclusion as to my opinion of ensilage for feeding dairy cows. Yours respectfully,

\section{B, COUNT'RYMAN,}

Dixon, Ill.

\section{ACTUAL RESULTS IN DOLLARS AND CENTS.}

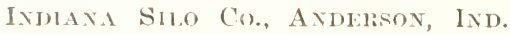

Gentlemen:-Answering your request for information as to the actual results obtained by me from the use of an Indiana Silo in dollars and cents I submit the following conservative statement:

I purchased an Indiana Silo in the summer of 1908 , size $18 \times 30 \mathrm{ft}$., at a cost of $\$ 300.00$. I put it on a concrete foundation and after the concrete hardened excavated to the bottom of the foundation four feet, therefore, I had a canacity of $18 \times 3+\mathrm{ft}$. Into this silo I put approximately 15 acres of colu estinated to yield about 800 bushels.

My baln holds 48 head of cows. I commenced teeding from the silo the first day of December, 1908, and ferl till the first of llay, 1909, a period of tive months, when my silo was emptied. My cows had nothing but silage and 'lover hay and came through the winter in beter shape and yielded a better flow of milk than they had ever done before. I put up atout the sanse amount of hay as usual but fed less than any other winter. I fed my cows before using silage, about one peck of crushed corn fir day witl clover hay. One peck of corn per day for 48 cows is 12 bushels per day and for a period of 5 months, or 150 days, is l,sol bushels of rorn. So my silo saved the first winter, 1,000 bushe's of coln which would have brought from 60 to 65 cents per bushel according to the time it was marketed. I sold $\$ 100.00$ worth of hay, something I had nevel done before having a silo and my acreage and yield was no greater than in former years. The year 1909 was the first year I ever got through without buying irom 1,000 to 2,000 bushels of corn. I, therefore, submit the following statement as to results for the first year of using silo:

C'ost of silo ...................\$300 00

Cost of erecting foundation and feed room.... 10000

Cost of filling................... 9000

$\$ 49000$

Saved 1,1100 bu, of corn at $65 c^{2} \ldots \ldots \ldots \ldots \ldots \$ 65000$

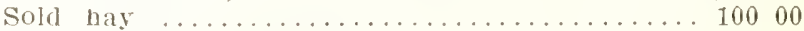

Cost of husking 1. acres............. 3000

$\$ 78000$

Aftel dedueting total first cost for the silo the statement shows a net profit of $\$ 290.00$. This year the profit or saving will be much gleatel as there will he no charge for silo and its erection. The only charge will be lor filling which is less than last year owing to the experience gained at that time.

I believe the statement submitted is conservative and the actual results greater than estimated. Yours truly,

G. E. COALE,

West Liberty, lowa.

I am solyy I have no photo of buildings to accompany this communication. 


\section{AFTER THREE YEARS' USE OF SILO.}

Indiana Silo Co., Anderson, Ind.

Gentlemen:-I will give my experience with silage. This is the third year since I first built a $14 \times 30$ foot Indiana Silo. The first year I filled it full, fed 25 head of cattle 7 months and had 8 weelis' feed left until the following July and August. When the pasture failed the silage was nice and sweet and carried my cows through the drought which would have been very expensive had I not had the silage. Since the first I have been putting in the silo from 12 to 14 acres of corn, from which I feed 25 head of cows and heifers and calves and a bull for seven months and it takes 4\% acres to pasture same cattle five months. Now you see with two silos I could feed the same number of cattle one year from the corn raised on from 25 to 30 acres, where by pasturing in summer it takes from 55 to 60 acles for the same amount of stock. Of course, you will need some roughness. I shred my corn that is left from the filling of silo and feed the shredded fodder to cows, some pea hay and some alfalfa hay. The richer the roughness the more milk there is.

Another profit in feeding silage according to my judgment is the manure made by feeding silage is worth double of that made by reeding dry feed. That has been my experience. My farm has been producing better every year since I built my silo. I feed everything in doel's, therefore, there is no loss of manure, which is of great value on the land. In this country a man with two silos ('an keej) 50 head of dairy cows on 100 acres and raise all the feed needed for them the year round and make his land better every vear. A man can't say too much for the silo for they surely are a great feed saver.

Another great point for the silo is the small amount of room it takes for so large an anrount of feed.

Another very important point is you don't have to wait until winter and bad weather to put your feed away. Fill your silo in the fall when the weather is good and when every bit of nutriment is in the corn or whatever feed you want to put in.

Another point, when you go in the silo pven in the severest weather you will be comfortable. Yours truly,

IV. E. COLVIN,

Cluey, Illinois.

\section{SILO TRIPLES CAPACITY OF FARM.}

\section{Jimand Silo Co., Andersox, Ind.}

Gentlemen:- In answer to yours as to the profits to be had from the use of silos, I would he pleased to say I bought my first silo upon the advise of another user, and to save a weedy piece of corn that did not promise more than 50 per cent a crop. Though I filled with corn, rag Weeds, jimpson and everything that came before the harrester, iti was all eaten, and proved as valuable as the same areses of good corn had previously done. Heifels which I had leen selling at $3 \frac{1}{2}$ cents were enough better to bring 4 cents. Steers that under like markets wnuld bring 4 to $4 \frac{1}{4}$ cents now brought 5 cents. Yearling and two-year o'd heifers and some steers, the next spring, paid extra profits, from the use of ensilage, to the amount of $\$ 265.00$. This was in the winter of 1904 and $190 \%$. In October, 1905, J bought a car of calves. The results of fecling silage, hay and some shelled oats until the following April were a gain at current prices of $\$ 550.00$. On pasture these calves did extra well, continued to grow and never scoured, but when very dry weather came they quit growing. Then and there I determined in the 
future to bave silage the year round. Mr. Wilson sold me a second and bigger silo so that when winter came I had besides my hay, corn and straw, $2 s s$ tons of excellent feed. The next spring I sold half my cattle at 51/4 cents, fed and finished on hay, ensilage and one-half of one feed of corn daily. The other half I sold the following August for 6 cents, finished on grass, ensilage and 1,000 lbs. of oil meal. The appreciation in plice alone gave me a net profit of $\$ 250.00$, more than enough to pay for my new silo. As Mr. Wilson had sold it to me to be selected from the rejected pile, I had fully convinced myself that a farmer could build a silo new each year an? make money.

Through the Indiana Silo Co. I bought a car of 59 heifer calves for $\$ 855.00$, kept them from Oct. 14, 1907, to Feb. 17, 1909, and received $\$ 2,623.04$. Though these calves were 14 days on the road, right from the cow, and were fed less coln than the previous load they were well finishod, selling but fic less than big steers the same day. As Mr. Wilson saw the figures for both ends of the deal the figures cannot be doubted. In this calculation 1 have not included 300 tons of prime manure which We put out last year. Here are some points easily verified among silo users: A calf will eat and assimilate ensilage at a younger age than any other feed. From it you can secure a finer coat and better finish in winter and early spring than from anything else. You can make more and better manure. Fon can carry three times as many cattle on the same farm, same size crop and same size expense account. Ten acres of corn sitoed is worth 22 acres used in the ordinary way. Cattle will pass from winter quarters on ensilage to smmmer pasture and continue their glowth and will not scour. The silo is the only way to get full va'ue from a crop of soft or late corn. Very truly,

\section{PORTER COPEI.ANT,}

Warrington. Ind.

\section{FACTS ABOUT OUR SILO.}

Indina Silo (Yo., ANDerson, INil.

Gentlemen:- We murchascl our first silo about one year ago and therefore have only had one yrar's experience lut that proves to be a benefit.

Before having the silo our grain ration for our herd of dairy cows cost $\$ 3.60$ per day and during the past winter it has cost $\$ 1.40$ per day with the use of silage. I have made no recold of the hay that was fed as we fed them what they would clean up fairly good during each wintri, but I am celtain from the appearance of our hay mow that we have not fed more than half the amount of hay we did before using the silage. We feed all the silage the cows will clean up, which is no certain amount of pounds as we are feeding all sizes from a large Holstein down to a small Jersey.

As we weigh and test our milk regularly $I$ ran say that other con. ditions consideled, I think silage will increase the milk flow at an avelage of $10 \mathrm{lhs}$. of milk per week over dry feeding and when it comes to figuring that amount on ton, twenty, thirty or more cows it proves silage to be of considerable financial benefit. I also wish to state that our cattle have never gon though the winter in better physical condition than during the past winter.

We ale very well satisfied with our silo and thank Mr. Swain, the president of the Indiana Silo Co. for impressing upon our minds the fact that. wa neederl one

J. C. BRUER \& SON,

Per E. C. Bruer,

McDowell, Ill. 


\section{NOTHING COMPARES WITH SILAGE.}

\section{InduANa Silo Co., ANDERSon, IND.}

Gentlemen:-The Case Dairy Company erected their first silo in 1905 , a small one $14 \times 30$ feet. We were so well pleased with the results obtained by the use of ensilage that we erected another one in 1907, 20x40. Con. tinued good results followed and our held having been greatly increased, the Indiana Silo Co. erected another still larger one for us in 190s. This silo was $24 \times 50$ feet ald was said to be the largest silo in Iowa.

All these silos have been filled with corn ensilage only and fed to our herd of dairy cows numbering from 50 to 100. Oul young stock has also been fed with ensilage as well as horses, hogs, and chickens and all animals fed on it have thrived on it and have come through the winter in better shape than the stock of neighboring farmers who have not fed

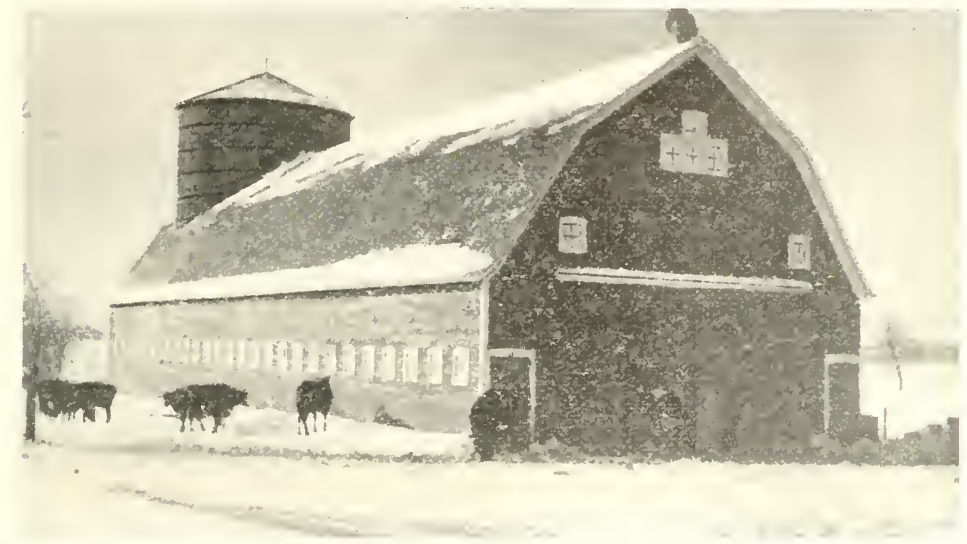

One of the Largest Indiana Silos Ever Built, on Case Dairy Farm, Waterloo, Ia.

ensilage. Milch cows, especially, do much better on ensilage than without it, giving more milk and presenting a much better appearance.

We have planted our corn in different ways, checking it in and rilling it. We have planted early and late, even as late as July 1st. However the corn is planted it makes good feed. A field can be kept cleaner by checking the corn in and there will be more ears, which is no objection. But the ordinary weeds that grow in corn fields make good feed when cut up with the corn and thus there is very little waste. We prefer to plant about four or five kernels in a hill, if checked, or to drill it pretty thickly, say five or six inches apart in a row. The ears, of course, are not so large, but the stalks are smaller and everything is eaten up.

The corn should be dented but the stalks and leaves should be green and juicy.

If an early frost nips the corn get it into the silo as quickly as possible before it has time to dry up much. We luave used some corn, how ever, that was pretty dry, but the ensilage kept well and marle excellent feed. If the corn should be too dry, water may be put into the blower and carried up with the corn.

We begin feeding immediately after the silo is filled. If feeding is not commenced at once a few inches on top will become mouldy. 
When feeding, a thin layer should be taken off the entire tols daily to prevent any spoiling.

We feel 40 to 50 lbs. daily to each cow, half in the morning and half in the serning. A little clover or alfalfa hay should be fed at noon. The heaviest milkel's should be fed mill feed in addition, say a mixture of bran, oil meal and corn meal, or bran, cotton seed meal, gluten meal, etc.

As regalds the cost of ensilage probably as good a way as any to get at it would be to name the pricts we have had to pay for ensilage we have bought of others when we had not enough of our own. We have paid $\$ 2.50$, \$3.00 and this year when feed has been unusually high $\$ 3.50$ per ton. We have lought coln of others in the field at $\$ 10.00, \$ 12.00$ and $\$ 15.00$ yer acre. We estimate that the entire cost of raising the corn and getting the thsilage into the silo should never cost more than $\$ 2.00$ to $\$ 3.00$ prer ton.

One ton of ensilage will feed one row 40 days if she is fed 50 lbs. a lay. That is five rents a day at $\$ 2.00$ a ton and seven and one-half cents a clay at $\$ 3.00$ a ton. Compare that with hay at the usual price and you will see the advantage in cost as well as in the health and productiveness of the cow.

An experience of five years has convinced us that no other roughage can complare with geod corn silage.

\section{I.AFA YETTE W. CASE,}

Waterloo, Iowa.

\section{SILO SAVED HALF ON MILL FEED.}

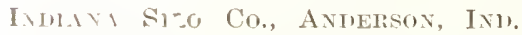

Gfulemen:- Received your lettre some time ago. In answer to your letter, my silo gives the lest results. It is a money-maker to the famer. 1st. It benetits in saving fodder. 2nd. you don't have to shuck the foddex in the snow or dig in the snow alter it. 3rd. It saves grinding corn because the corn is in the silo.

We shipped more milk this wintel than we did other winters from the same amount of cows. They are in better shape and look better than they ever alid and I only feed half a gallon of bran to each. Other wintels we fed one gallon of bran and ons gallon of elushed corn to a ferd, whirh we saved through our silo anl our cows like it better than any oflue [ew]. It gives more manne in the barn by feeding silage. Tliat is what we want, to make the slound good so we can raise better collu for the silo. Our silo is empty now and ready for another filling. Yours trily, ATGLST ABERT,

Kantiman, Ill.

\section{ADVISES EVERY FARMER TO BUILD SILOS.}

Ixmini Sulo Co., Axmersox, Ixw.

Gentlemen: The Indiana Silo purchased last year gives entire satis faction. I have never had cheaper feed for cows than corn silage, and nevel dirl my cows do so well in giving as much milk all winter as they have this your.

We also nsed a distributer which gave entire satisfaction and helps to kepl the silage. We did not lose any silage from decay only on top. The sides all kept well, all in gool condition all the way down. Hardiy any loss near the foors, mono was so had that the cows did not pat it.

I would advise every farmer with 10 head of cattle to usc an Indiana Silo. I helieve they are the cheapest and best made silos on the market. TVe think we have savol one-half the enst of the silo this season. Yours truly,

WI. IUGSPURGER \& SON,

Rensselaer, Ind. 


\section{EIGHT ACRES OF ENSILAGE KEEPS TWENTY-FOUR CATTLE.}

Ixidaxa Silo Co., Axpersox, Ind.

Gentlemen:-We received your silo in first class condition. We found it easier and cheaper to fill the silo than to cut and husk the corn.

We fed 16 cows, 4 young cattle, 4 calves, a sow and 10 November pigs on ensilage and will have enough ensilage to feed until grass comes. Our stock we fed on silage is doing well, in fact, I think ensilage is the cheapest feed a farmer or dairyman can use. We have got the best results from $\delta$ acres of corn, in fact, better than we could have gotten with

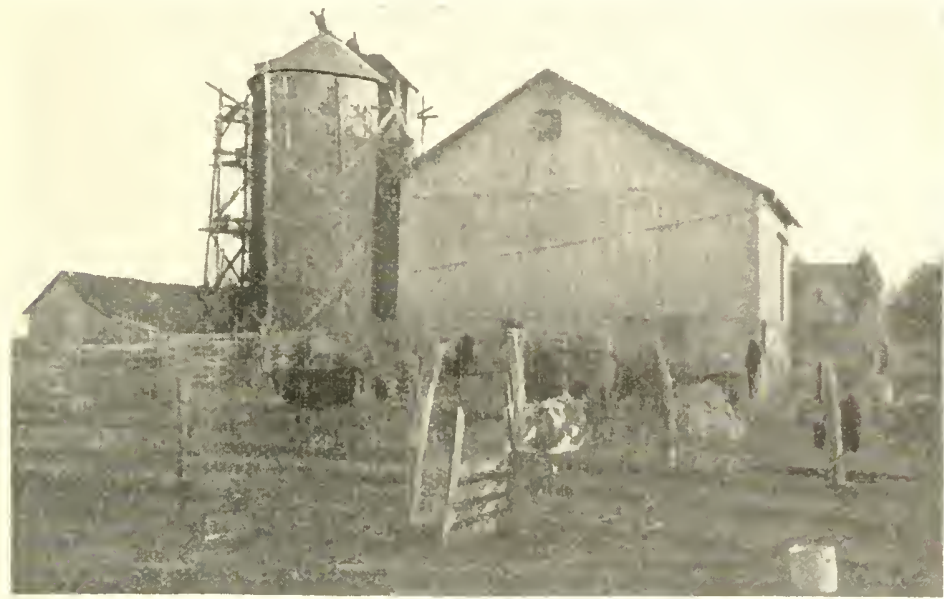

M. R. Allen's Silo, Near Bellefontaine, Ohio.

any other feed. We have bought less bran the past winter and our herd looks and milks better with ensilage than with any other feed. Yours respectfully,

M. R. ALLEN,

Highland Dairy Farm,

Bellefontaine, Ohio.

\section{COWS FALL OVER EACH OTHER GETTING TO SILAGE.}

Indiana Silo Co., Anderson, Ind.

Gentlemen:-We are well pleased with our silo. Our cows were fatter this winter than they ever were since we owned our coms. We got one-half more cream.

The cows fall over each other getting in the barn to get their feed. Before we got our silo our cows went dry eight weeks before time to find their calves. Now we can't get them dry long enongh to find their calves. We oniy feed them silage and a little corn fodder outside of the barn.

If I only had six cows I would fill my silo. We wouldn't know what to do without silage now, for it is so good to feed the cows when the pasture is so short.

I hope you will have good success in your good work. Yours truly, JOHN W. ANGLIN,

Etna Green, Ind. 


\section{A REPORT IN FIGURES.}

Inimana Silo Co., Anderson, Ind.

Gentlemen:- Like many other good things the silo can show added benefits the longer it is used. I filled my silo the first time in 1904 and it has been in use every year since. My purpose was to supply my dairy with a substitute for grass during the winter season, and thus provide a better balanced ration, but I soon wanted silage through summer drouth, also when pasture was poor, or almost a minus quantity. After experiencing the drouth of 1908, I bought a second Indiana Silo and can now supply 30 cows with silage every lay in the year. I had previously tried renting pasture of neighbors and found it took the profits and also built up the other fellow's ground.

The two silos hold two hundred tons and the filling of them for 1900 cost as follows:

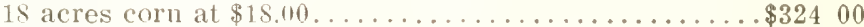

6 pitchers at $\$ 2.00$ per day for $2 \frac{1}{2}$ days........... 3000

3 men to tramp at $\$ 1.50$ per day................ 1125

Man and team to exchange with neighbors 10 days.. 2000

Cutting corn with binder at $\$ 1.00$ per acre...... 1800

Twine for binding..................... 600

Fuel for engine......................... 600

Three dinners for men at $25 \mathrm{c}$ each........... 1350

Charge for ensilage cutter at 25c per ton......... 5000

Total cost for silage...............\$478 75

This makes the cost per ton $\$ 2.39$ for a feed that is worth much more for a farmer.

I have also found that the corn which goes into the silo is harvested in its most desirable stage and in a more pleasant season for the work than that which is harvested ly any other means and with far less loss, for the coln is cut off at the ground and the entire plant is saved. The silos are practically as good as ever for using and I expect to see silage go into them many more years. Yours respectfully, I. I. ATKINSON,

Cambv, Indiana.

\section{WOULDN'T BE WITHOUT SILO.}

\section{INDIANA SIIO CO., ANDERSON INI.}

Gentlemen:- In answer to your letter of a short time ago, I would say your silos are all light. I fed silage to my cattle and sheep; never had them so well before. Fattened six head on it ready for market and they were in good shape. I also fed my sheel onco a day and never had them do so well lambing and the lambs are large and strong.

I would not be without a silo after sfeing the good results of one. Yours respectfully.

SAMI E. BROWNEIAL,

Cedar Springs, Mich.

\section{A GLIMPSE OF ITS EARNING POWER.}

INDiAxa Silo C'o., AxDERSox, INI.

Gentlemen:- T bought a silo from you last August. Put 12 acres of corn that would make about 30 bushels to the acre into it. Have teel 25 steers 6 months, besides two milk cows, 14 sheep, 4 mules. Am feeding yet but don't know just the amount of profit, but to sell now would make $\$ 600.00$ on the steers. I regard it the best investment I ever made, saves feed, saves rent, saves every way. Yours truly,

W. F. BROWN,

Modesto, Ill. 


\section{ONE ACRE MADE TO EQUAL MORE THAN FOUR.}

Indixa Silo Co., Anderson, Ind.

Gentlemen:-Your letter of the 12th inst. at hand inviting me into your contest. Thanking you for same I am sending photograph of barn, herd and self under separate cover.

This being my third winter feeding ensilage from an Indiana Silo I feel as I have given it a fair test and in position to recommend same to others. I have never practiced soiling so have only fed ensilage during winters of 1907-08, 1908-09 and 1909 and -...

I have a year's record of 5 registered Holstein heifers which freshened in Oct., 1907. Record began Nov. 1, 1907, and continues for one year, and does not include calves or value on manure. All feeds were counted at their market prices. All were fed alike.

Cost of Feed per Cow per Day. Ensilage, 40 lb.........\$ 48 W. Bran, 4 lb.......... 50 Corn, 4 lb............ 30

Linseed Meal, 1 lb........ 16 Clover Hay, $10 \mathrm{lb} . . . \ldots . . .30$

Total ............... $\$ 174$
Cost of Feed for Five Cows 172 Days.

Ensilage $\ldots \ldots \ldots \ldots \ldots \ldots 4128$

Bran ............... 4300

Corn ............... 2580

Linseed Meal ........... 1376

Clover Hay.............. 2580

Total

$\$ 14964$

Pasture 194 days

$\$ 3000$

Total cost of feed for 366 days $(1908$, leap year)......\$179 64

Gross returns, $\$ 406.15$; feed, $\$ 179.64$; net............\$226 51

This amount of feed produces over 21 tons of milk. Note-The ensilage in this case being a highly succulent food, takes place of high priced concentrates, about 17 tons of ensilage less than two tons of bran, about 50 bu. of corn, $4 \frac{1}{2} 2$ tons of hay.

According to feed analysis, one ton of timothy hay contains practically the same digestible food elements of $2 \frac{1}{2}$ tons of corn silage. Therefore, 17 tons of ensilage is equal to 64-5 tons of timothy hay, or in other words, I pay for the same food elements, 17 tons of ensilage, $\$ 2.50, \$ 42.50 ; 64-5$ tons of timothy hay, $\$ 10.00, \$ 68.00$.

Then the food elements in ensilage are the cheapest by $\$ 25.00$.

Average crop timotly hay here $1 \frac{1 / 2}{2}$ tons at $\$ 10.00-\$ 15.00$.

Average crop ensilage, same land, 10 to 14 tons at $\$ 2.50-\$ 35.00$

Therefore I produce the same food value on one acre of ensilage (14 tons) as on 4 2-3 acles of timothy hay. I estimate my ensilage at $\$ 2.50$ per ton as it made 14 tons per acre or $\$ 35.00$. I know of no other farm or general crop grown in this locality that equals this on $\$ 60.00$ acre land. I compare it to timothy hay because almost every farmer knows its feeding value.

During the winter of 1907.08 I took 5 yearling heifers through with nice growth on $16 \mathrm{lbs}$. of ensilage per day and only wheat straw for roughage. This winter four two-year-old heifers are going through in fine shape on $20 \mathrm{lbs}$. of ensilage and a liberal allowance of shredded fodder in morning and timothy hay at night. These heifers mentioned are grouped near center of photograph,--the five cows at right and in the background. My silo is in high part of barn-shed or as some term it, shedded barn lot. Silo is $12 \times 22 \frac{1}{2}$ feet deep, estimated capacity about 45 tons, 14 men fill it on an average of 7 hours on a 60 rods haul.

I have also derived good results in feeding ensilage to my hogs, 


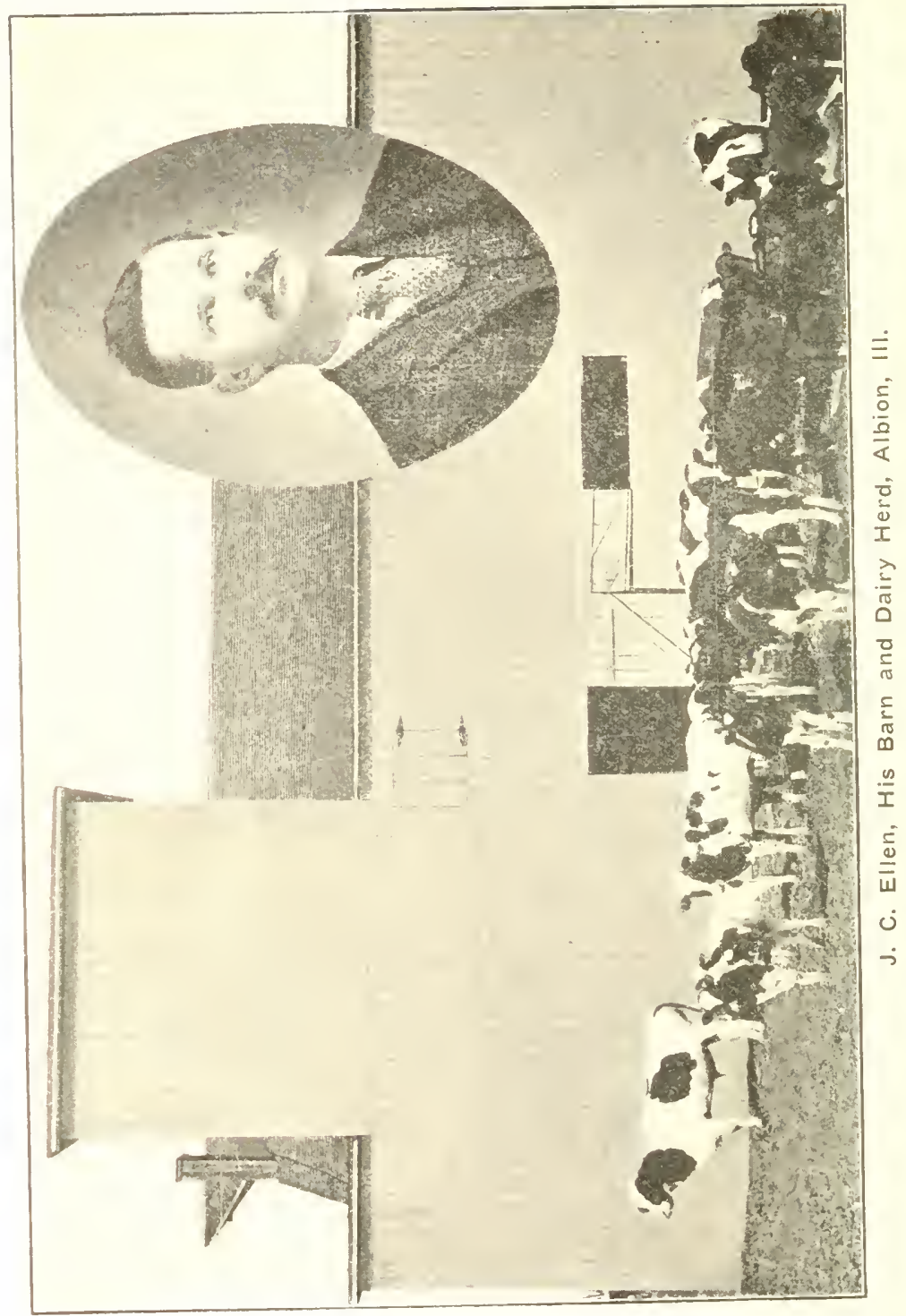

especially to my Duroc brood sows before farrowing and during suckling. Have, also, fed it to a small flock of each, poultry, sheep and Angora goats whell weather made housing necessary.

Since I have fed ensilage it requires only about one-half the roughage as did before. Respectfully submitted,

JOS, C. ELLEN, Albion, Ill. 


\section{THE BEST INVESTMENT A FARMER EVER MADE.}

Indjana Silo Co., Anderson, INd.

Gentlemen:- This is the fourth season for my silo and I am firmly convinced it is the best paying investment I have ever made. Not only are the corn stalks (which contain about one-thild of the feed value of the entire crop) saved in this way but a big profit is realized on the stock that is fed the silage. Another point in its favor is that one does not have to farm so heavily and yet be able to winter a greater number of stock which is necessary for the improvement of the land through this section of the country.

My silo is $16 \times 2 \frac{1}{2}$ and is rated at 100 tons capacity. T'welve acres of good coln will fill it and from experience I have found it will winter from 50 to 60 head of stock with the noper amount of roughage and in the spring come out in fine conclition. Last year I had a herd of 30 cattle. Part of these I fed silage and clover hay and the rest clover hay and a little corn. When spring came the silage eaters avelaged 100 pounds more than the non silage eaters. Cattle then being 5c, my

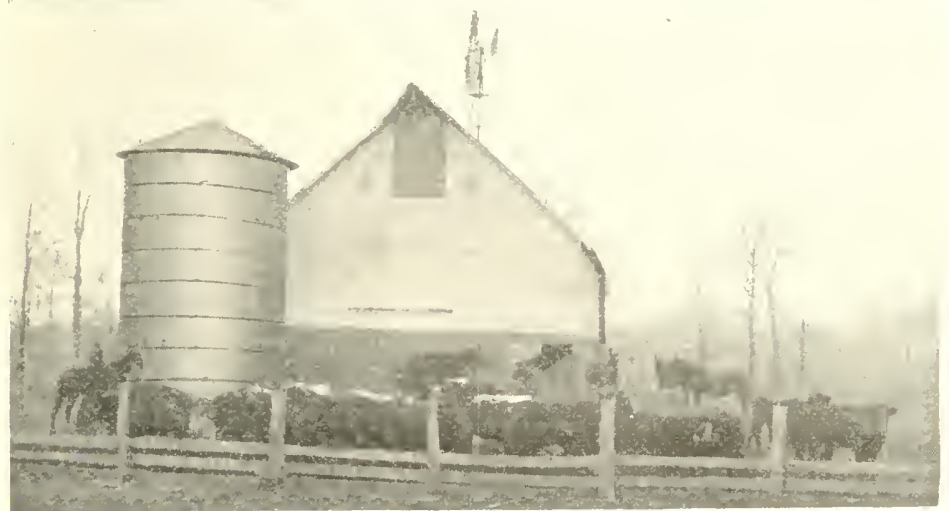

Feeding Plant and Stock of Jno H. Brosman, Martinsville, III.

gain was $\$ 5.00$ per head and if 1 had fed them all on silage my gain would more than half yaid for my silo. If properly fed one will pay for itself in one season. One has to exelcise care in feeding silage for stock is so fond of it that they will eat too much.

I especialiy feed it to my milch cows and find it to be as great a milk producer as clover hay. It gives winter butter a fine flavor and a golden tint. I am feeding it to my holses as a midday feed which gives them a good appetite and keeps them loose which promotes an early shedding of the hair and gives it a fine gloss.

My sheep are going through the winter in tip-top condition and I consider it a great feed for ewes that are lambing as it increases the milk supply.

My wife even feeds it to her chickens when they cannot get green food and it keeps up the egg production.

I have fertilized 20 acres a year since building the silo and before only 10 acres a year. Of course these figures show I am keeping twice as much stock on the same number of falmed acres. I consider my farm has increased three to five dollars per acre since the building of the silo. 
Indiana Silo Co., Axblison, Ind.

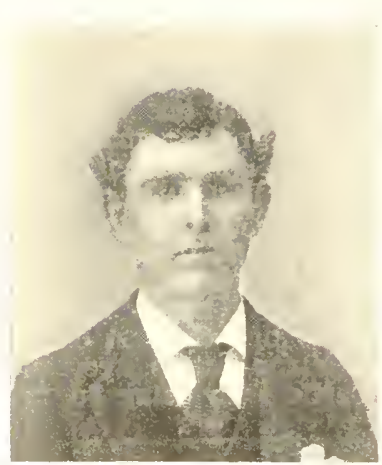

Robert Bruce,

New Douglas, III.

Dear Sirs:-I purchased an Indiana Silo from your agent last summer and am more than pleased with it.

Ensilage is the finest feed I ever fed. I teed it to calves, sheep and horses with good results, and for milking it can't be beaten. Here is the difference in my milk this win. ter with that of last winter:

In December, 1908, my milk brought me $\$ 44.64$; in December, 1909 , \$70.55; in January, 1909, $\$ 37.92$; in January, 1910, $\$ 76.50$; in February, 1909, \$29.12; in February, $1910, \$ 71.04 ;$ March, $1909, \$ 38.40$. I have not got the March milk check yet, but it will be about $\$ 75.00$.

Last winter I fed ground corn and bran and have not $f \in d$ either this winter.

What the Indiana Silo has done for me it will do for other's. Yours for success,

ROBERT BRUCE, New Douglas, Ill.

\section{A DIFFERENCE OF $\$ 262.18$ IN TWELVE MONTHS.}

INdina Silo Co., Axderion, lish.

Gentlemen:- It is the main ohject of most stockmen and dairymen to cheapen their feeds and at the same time obtain the best results, and by relying unon the experiments of others, together with thair own study and experiments. They strive to bettel their herd, farm and themselves by keering an account of what is paid in from the herd or farm and what is paid out. They can determine the amount of gain. They also study the difference between producing their supplies and purchasing them. Having followed dairying for a number of years 1 follow the systenl of accounts.

During the spring of 1908 l ordered a $12 \times 28$ silo of your agent, erected it over a saven foot pit ans filled it during the season with (as an experiencer man saill) No. 1 silage, putting in about seven acris of coln or about 90 tons of silage.

I began fecding 12 milch cows about October 1st, 1908 and through the winter months three adlitional heifers and a bull. I fed all until May 15th and the mileh cows once a day until September 20th.

The amount received 1908-09 from 12 cows, creamery statements, \$751.05. I paid out for oil meal for 12 cows during winter months, 2 tons at $\$ 32.00$, making $\$ 64.00$, leaving a total of $\$ 687.05$ for the sea. son of $1908-09$.

Now the season previous, 1907-08, I purchased for 12 cows 10 tons bran at an average price of $\$ 26.00$ per ton and 2 tons oil meal at $\$ 32.00$ per ton, making a total expense of $\$ 324.00$ for season of 1907.08 . I received for the season (creamery statements) $\$ 748.87$, less expense of feeds, leaving a total of \$424.87. This makes a difference between the two seasons of $\$ 262.18$ in favor of the silo. My summer pasture is woods and mostly dry short grass. Count the silo for me. Yours respectfully, 

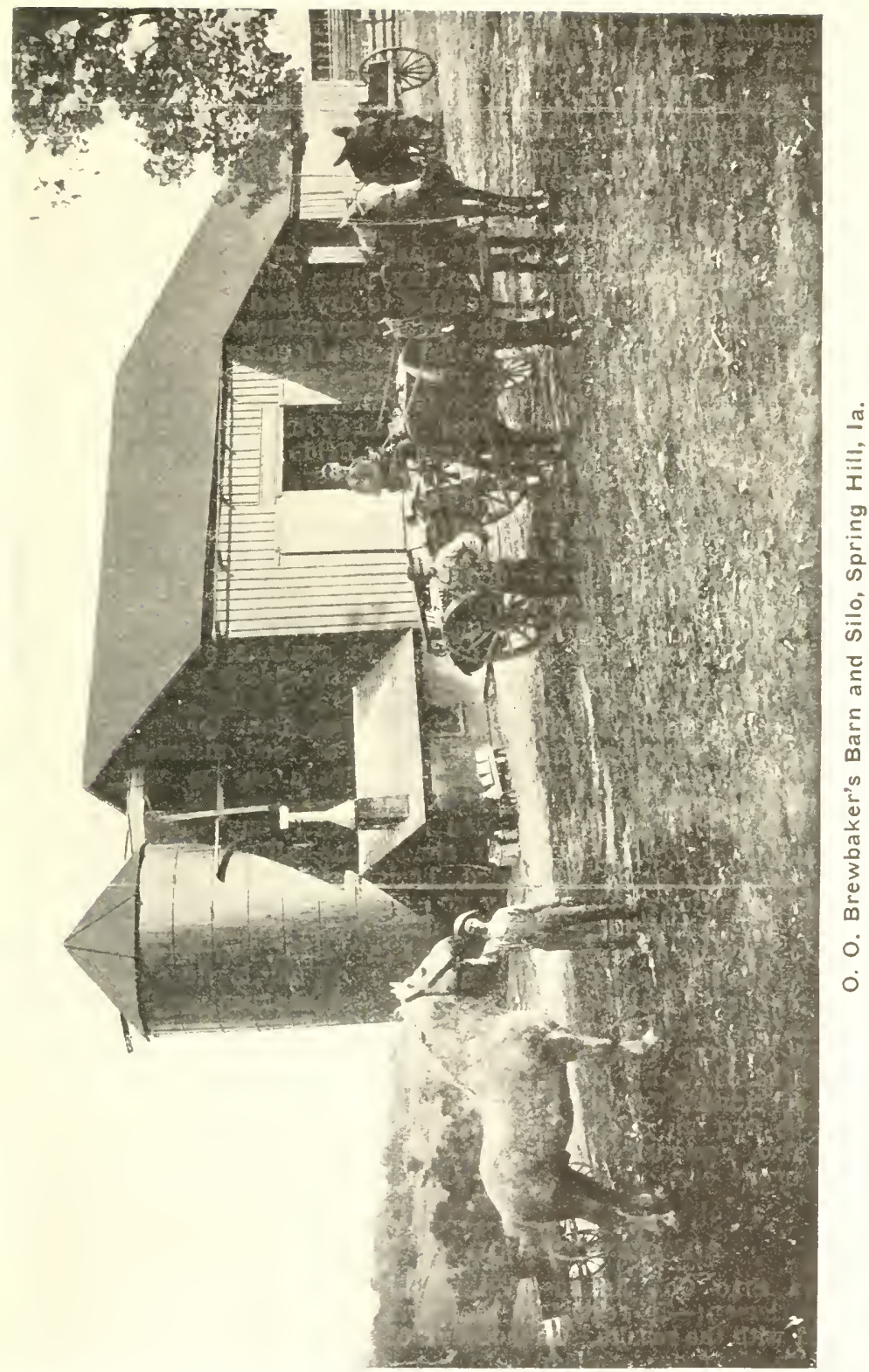


\section{THE PROPOSITION FRANKLY PUT AND PROVEN.}

Inimaxa Silo Co., Anderisun, Jxo.

Gentlemen:-As larmers and stockmen we are working for money. No matter what specific line we pursue, whether feeding for beef, pork, mutton, milk, cheese, or butter, we believe that the man who uses the combination of feeds that give the best results for the least money is the only man who is making the nost of his time, brains and money, so far as his business is concerned.

I believe of all feeds known silage stands pre-eminent. It furnishes bulk for distention, succulence for the appetite and nutrition for strength, growth and production.

By the use of the silo for the past six years, I have leen able to double the number of animals on my place with only a little more expense for feed than it would require to dry feed one-half the number in the winter season, besides the great convenience of having my feed under cover and right at hand which makes feeding a pleasure.

The silos has enabled me to utilize my poor patches of corn in low places and late fields that otherwise would have been frost bitten, and convert it into rich juicy feed, relished by nearly all animals on the farm. It has enabled me to clear my fields of the corn crop in the early fall, for the sowing of wheat or rye, thereby helping me to reduce the spring work to the minimum.

It has increased the value of my land, not only by being a per. manent improvement itself, but by furnishing teed which alter being converted into manure is at once in an ideal state to amalgamate with the soil, without containing a live weed seed to harass my future crops. It has enablel me to save the sugar and other nutritious elements of the corn stalk, representing, according to analysis of our experiment stations, from 35 to 40 per cent of the entire plant which, under any other method yet devised is nearly all waste.

It has enabled me to economize storage room for feed. It being possi?le to store three times the amount of food materials in a silo as in a barn, in either case basing the feeds on the amount of dry matter contained.

The use of silage has enabled me to carry my stock through the most trying seasons of the year almost one-half cheaper than by any other method I have ever tried, besides keeping them in the best physical condition; so that they go mpon the grass in the spring without loss or detrimental effects. By actual monthly tests I have increased the milk flow of my dairy 33 per cent in weight, by the substitution of silage as the base of the ration instead of all hay, besides cutting down the grain vart of the ration one-third, and cheapening the ration for cows in full flow five cents per day, making a net average difference between the two methods of feeding of fifteen cents a day per cow. On a herd of twenty cows this would figure three dollars, ninety dol. lal's per month, five hundred and forty dollars in six months which would be two fair sized silos.

I have demonstrated this to my own satisfaction and can prove it to anyone else.

O. O. BREWBAKER,

Spring Hill, Iowa.

\section{SILAGE GOOD FOR ALL KINDS OF STOCK.}

INDIANA Silo Co., ANderson, IND.

Gentlemen:- In regard to the profit in the silo we are pletty well pleased with the results. On account of the wet season we were compelled to plant our ensilage corn the 11 th day of June. The corn was very tender and from ten to twelve feet high. On the 25 th day of 
August there came a flood and swept the corn fiat and it looked like it had been rolled with a roller. If it had not been for the silo it would have been almost a total loss. We cut the corn the latter part of September. We opened the silo the 17th day of November. We found about eight inches spoiled on top, but the rest kept fine.

We have been feeding four horses, four cows, twelve head of hogs, twenty-five breeding ewes, and a flock of poultry. We find it fine for all kind of stock. 'The hogs expect their ensilage as much as they do their corn and slop. We put about three and one-half acres in the silo and it took about half what it would if we did not have the silo. We got eggs all winter and this we owe to the ensilage.

We think that every man, though lie has but a small farm, should have a silo.

Well, wishing you excellent success in the silo business, I remain as ever, your respectful friend,

HARVEY B. BRIGHT,

Marengo, Ohio.

\section{INCREASED PROFIT ON TEN ACRES PAID FOR SILO IN A YEAR.}

Inmaxa Silo Co., Anderisux, Ind.

Gentlemen:- How to get the most out of the crop is a problem that has been solved by the silo. The old way of taking care of crops must give way to the more modern way of siloing. Just as sure as the cradle gave way for the reaper and the hoe for the riding cultivator, just as sule and as slow will the old and wasteful way of feeding and wasting of the crop give way to the silo.

Ten acres of good field corn will make 100 tons of ensilage worth four dollars per ton or $\$ 400.00$ for the 10 acres. Ten acres of good field corn handled in the old way will make 500 bushels of corn worth $45 \mathrm{c}$ per bushel or $\$ 225.00$. It will not cost any more to put ten acres of corn in the silo than it will to husk and market the corn. What is true of coln is also true with clover, alfalfa, oats and peas. The silo is the place for it.

Seventecn years ago I started in the dairy business. In the summer I raised my crops between milking times, working about 22 hours out of the 24 and in winter and fall in mud, sleet or snow I was hauling in and harvesting the crop just like my neighbor dairymen all around me. wasting a out one third in the operation. Finally I let somebody talk me into buying a silo. I had not made any money the first few years and bought the first silo on payments. After I had the first silo up one year I bought another for cash. Now I have four silos and am doing fine, but if I was to do without the silo I would quit business.

We now put our crops in the silo in summer and fall while the days are long and when bad weather comes we have all the feed under roof. Do not have to get out in the wather and can do with less help and less horses. A man with a silo can sell milk for 10c per gallon and make as much noney as the man willout a silo can selling at $15 \mathrm{c}$ per gallon.

The silo cheapens the production of milk one-third. Ensilage hetters the quality of milk and butter and malies it more saleable on account of its superior color. Ensilage milk in winter has the appearance of grass milk. The man who bas a silo full of ensilage, whether it be corn, clover, alfalfa, oats and peas, wheat or lye, need not lear droughts of summer of the inclemency of winter. He has the pasture all the time. $\mathrm{He}$ is fixed. 


\section{ORNAMENTAL AS WELL AS USEFUL.}

Indiana Silo Co., Axderson, Ixd.

Gentlemen:-Two years ago l purchased of your agent one of your silos, and will give you a few plain facts in regard to the benefit it. has been to me.

I wish to say that since I purchased mine four of my neighbors, who were not in favor of a silo, having resisted all persuasion from different agents, but upon their investigation and observation of results from the use of mine the first year, each purchased one for their own use. I consider that a very good ad. for the silo.

The first yeal l found upou close figuring that I paid for my silo by the difference in feed in that year and the yeal plevious, my stock requiling very little grain, beside the silage. I found that I did not reciuire to feed my milch cows only about one-half as much grain as the year previous, withont a silo, and the milk yield was greater. I find after using the silo two years, there is nothing to take its place. There is no waste and I con care tor the stock in about half the time, requiring no heavy lifting or working out in stormy weather. The cost of filling my silo was no more than caring for the corn in the ordinary way and it is all lone about a diy and a half. The fields are clear for fall plowing and ons that fontented feeling that all is safe for winter use.

I have an so acre farm and I am thinking of erecting another silo next fall for the $n \div$ oi $m$ y stock in summer. 1 can then keep 25 milk cows and know that l can keell them well.

I can recommend the Indiana silo to be all and more than it is lepresented. I found no trouble in erecting it myself, every piece fitting together perfectly and atter two yeals of use it looks as well as when first put up. No signs of lecay. It is an ornament to my farm buildings. I have had many come in and ask me the cost of it and the profit to me which I am always pleased to tell and though I am a man of lew words I am always glad to pass a good thing along.

M. ANDERSON,

Elkholn, Wis.

\section{SILAGE INCREASES A COW'S BUTTER OUTPUT OVER FORTY POUNDS A YEAR.}

Indiana Silo Co., Axperson, lise.

Gentlemen:- In regard to freding ensilage to dairy cows I will give a statement of what I have experienced in using a silo.

I am now feeding ensilage the second winter. We are running a dairy of 17 cows at present. Now before we had a silo we averaged about 198 pounds of butter to the cow a year, by leeding ground or crushed corn during the wintel and also oil meal and bran the year alound. Now since I am feeding ensilage I feed oil meal and bran the same as before, but no other choy of any kind and I can now figure up an average of about 240 pounds of butter to each cow per year, which will leave a profit to the silo of 42 pounds of butter to each cow, besides saving of grinding corn and also taking less rough feed.

I purchased an Indiana Cypress Silo, 14x26, ill 1908. Four and a half acres of good coln will fill it. I feel as though a good silo will pay for itself in two feasolns. I would not want to run a dalry without a silo. Respectfully,

C. S. BEACHY.

Plain City, Ohio. 


\section{FEEDING UNREASONABLE WITHOUT SILO.}

Indiana Silo Co., Axderson, INo.

Gentlemen:-Having lived in a neighborliood for some years where there were a number of silos and having fed cattle for the same period without proper success, concluded to buy a silo. After investigating all makes and kinds in the summer of 1909 we made up our minds to erect one and purchased the same of the Indiana Silo Co, which we then believed to be the best and have not changed our minds. The silo having arrived on the ground we had it erected at very little cost in the last days of August. Everything so far to our entire satisfaction.

Having purchased a Blizzard cutter about the middle of September we commenced to fill the silo which was a very small job compared with the amount ot feed put in the same. Think of it, twenty-five acres or more of very heavy corn was put in that silo all in tangible and fine condition to make those one hundred and twenty-five calves' mouths water in those cold days to come from January 1st, 1910, and on. The calves we propose to talk about are spring and summer calves of 1909 and we propose to make baby beer of them as stated below. We put the above amount of calves on this feed about the 26th day of December, 1909, with a ration of silage, crushed corn and cotton seed meal and have fed them all the silace they would eat since that time and at this writing have fed about half of the silage and will have plenty to finish the calves about the first of June. Will say our silo

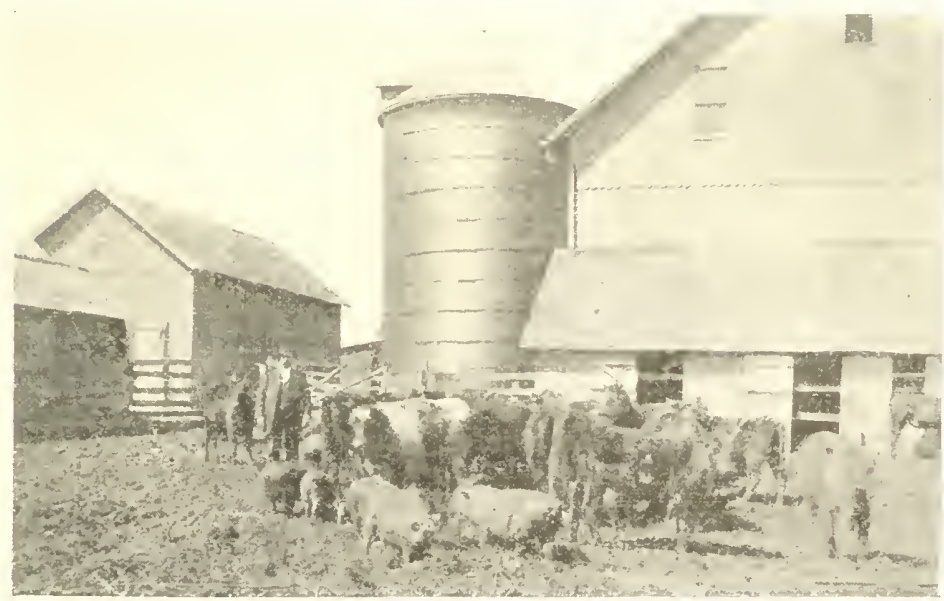

Bartlett Bros'. Cypress Silo.

is $20 \times 30$ feet, made of Cypress.

As we did not weigh those calves when we first put them on feed and have not done so since cannot give actual figures as to their gain but to say they have done well would be expressing the truth and a good thing in mild terms.

These calves are the talk of the community and at all times have Ietters from commission men from all the leading markets as to when they will be ready to sell. We made up our minds that to feed cattle without a silo would be about as unreasonable as to feed without corn. 
Another important question to take into consideration in using the silo is this, you are liable to harvest your corn crop at a time in the year that you haven't much to do on the farm, giving you the finest chance on earth to sow the ground in wheat, and to think of the amount of cold fingers that are avoided by putting that corn crop there ready to feed in a nut shell. The truth of the matter all told, there is nothing on the farm equal to a silo and we believe that one made by the Indiana Silo Company is as good as the best.

Gentlemen, wishing you success in the manufacture and sale of your silos, we are, very respectfully,

\section{BARTLETT BROS,}

Per J. A. Bartlett, Lemisvilie, Ind.

\section{HAS TWO NOW AND WILL BUY A THIRD.}

IxDlaxa Silo Co., Aximpion, IxD.

Gentlemen:- In relly to yom request to give an exact account of what I am doing with my Indiana silo, I filled it last year from which I fattened 28 head of grom catt?e. Made then ready for the butcher which gave me a net jufit of $\$ 450$.6n and I am feeding 25 cattle this year that I am sure will make equally as much money as last year.

I never had am! damaged silage The only trouble I have is that I donth have enough siage to feed ertrything. I already have two silos and count on buying the third one this season. I don't see how any farmer can afford to lie without one.

Please stnd me rour catalog and give me your best prices. I think there can be as many as a carload sold hele this season. I want one the same size I bought flom rou before. 12x30.

Let me hear from you soon. Yours respectfully,

J. H. BENIETT,

Burlington, W. Va.

\section{AN ESSENTIAL THING ON A FARM.}

I.ITAXA Silo Co., AxDersor, IX̃.

Gentlemen:-In reply to your request asking me to write my experience with your silo, I have used a silo for several rears for nearly all kinds of stock. I have fed cattle with good results for fat cattle. I foed it with corn

I fed twenty-one head last winter. They went to market fat, and I alco fed nne hundred head of sheep. I gave them all they would eat with a little shell corn and some clover hay. They got very fat. It diunt requile rery mucli corn. For cows there is no better feed. They give a good flow of milk on it and it keeps them in good condition. and for calves there is no better feed. I have been feeding calves for serelal years, flom tifteen to twenty evtry winter. Ther grow and do fine on it without any other grain. For sows that are going to farrow in the spring it is an excellent feed. It keeps them loose and in good shape. We feed our horses some. They relish it and it keeps them in good shape. Chickens do well on it. We feed our hens and we got eggs all winter. I think it is one of the essential things for a farmer to have. I think we cannot aftord to feed without a silo. It is a very cheap feed and always ready and the cost to put it in is very small. I have never fed it alone, therefore, I can't give any statistics as to weight, but I have always fed it with good results. Respectfully, 


\section{A LIFE TIME HELP PAYS FOR ITSELF IN ONE YEAR.}

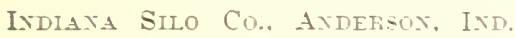

Gentlemen:-A silo is almost a necessity to a successful dairyman, for if a dajryman is reeding hay or dry fodder without silage he must feed a large quantity of mill feed to produce milk, but if he is feeding silage he does not bave to ieed so much mill feed, because of the corn and other food elements in the silage. There is as much nutritire ralue in good silage as there is in green fodder and makes as good a milk producer as green grass which is the best milk producer there is. Then fodder is left in the shock to be jed in the winter only about half of it is all eaten by the cows. Eren dry fodder il dampened with water as it is tramped in the silo will make almost as good silage as green fodder. Eight acres of good corn will make 100 tons of silage. Allow: ing $\$ 20.00$ for plowing. $\$ 12.00$ for harrowing, $\$ 25.00$ for cultirating. $\$ 3.00$ for seed and $\$ 50.00$ for putting it into the silo it Would cost $\$ 110.01$ for 100 tons of silage or $\$ 1.10$ a ton, and feeding 40 pounds a day to a com 100 tons mould feed 25 coms for 200 dars or about six months. A little hay should be fed once a das with the silage. If these eight acles mere to produce 14 tons of cloter hay and if 10 pounds $\pi$ ere fed to a cow in a day it mould last 25 cows ior 112 dars or nearly four months, and since a good crop of clorer hay is seldom grown more than once in three years, clorer hay mould hare to be bought and would cost about \$2iog0 for the 14 tons. This makes a difference of $\$ 70.00$ which, together with the cost of hay for the other two months and the extra amount of mill feed used when feeding has, would more than pay for an Indiana Silo. which owing to its proven superiority in material and structure will last a lifetime. Fours truls,

J. II. BOYD,

East Liverpool, Ohio.

\section{SILAGE IS THE EEST SUBSTITUTE FOR GREEN FOOD.}

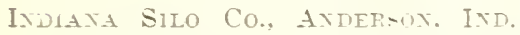

Gentlemen:- I am unable to give rou exact figures but an safe in saying that I sared over $\$ 200.00$ or the price of the silo in one Jear.

Mr. Detrich claims that ensilage is as near June pasture as any. thing you can get. He ought to know as he has kept 20 cows on 15 acres. He has made a great deal of moner from his coms and he presents erelything flom a practical riempoint oi a farmer whose chief interest is to make moner and to make a great deal of it from his land, while preserving the iand.

I raised a number oi pigs this minter on less grain than erer beiore, bs the aid of ensilage. It is one of the grearest feeds for sheep that has erer been gromn on a farm, and as to wintering horses, it cannot be excelled. I hent two colts this winter principally on ensilage and now they are slick and glossy as though they had been on pasture.

The silo is still in it: infancy as a beef-maker but when its usefulness is fully realizer it will be considered as essentia? to beet produc. tion as it now is to milk production.

Chemists tell us that 70 per cent of the good of the corn stalk is below the ear. If this be true, how are we going to get ralue receired out of the fodder it we don't use the silo?

Silage is the best known substitute for natural green feed.

The proceeds of making silage adds nothing in the may of food elements and produces practically no chemical change. It does take the crop then it possesses the greatest amount of digestible nutrients and preserves it in that condition. The fermentation which takes place 
adds a relish which is greatly appreciated by cattle and sheep. Silage is a palatable green tood supplied at a time of the year when it can not be economically supplied in any other form.

A silo may be constructed of stone, brick, cement or building tile. At present these materials are more expensive than wood. From my own experience and what I bave learned from otbers through agricultural papers, will say to build a round stave silo for the following reasons:

It should be strong to resist the enormous pressure of the silage, air tight when erected, convenient in construction, free from internal projections and easy to set up.

Some farmers eke out a mere existence, they do not realize what nature has in store for them by putting it into practice.

It reminds me of the story of the farmer at Institute. He heard the lecturers talk about building silos, feeding cows ensilage, so be was telling his good wile that he was going to build a "cyclone" and feed his cows "mucilage."

Condensing valuation of land and price of concentrates, the silo is the most economical investment a farmer can make.

M. C. BANKS,

Beaver Falls, Pa.

\section{TWO COWS CAN BE KEPT WHERE ONE WAS KEPT BEFORE.}

Inlulaxi Slio Co., Anderson, Ind.

Gentlemen:-1 bought an Indiana silo of your agent in 1908 and find it a paying investment on $m y$ small farm of 51 acres. The man without a silo in this time of expensive commercial feeds is certainly handicapped in competition with the man with the silo. There is no longer a question in my mind or in the minds of dairymen and cattle raisers, or any man that has given the question thought, about the merits and cheapness of silage as a feed both for dairy cows and young stock. There is nothing on which cattle or young stock will thrive and look so well as well kept silage. It also aids to keep up the fertility of the farm. Whoever makes two blades of grass grow where but one grew before is a benefactor to mankind. A silo makes it possible to keep two cows where but one was kept before and who would not gladly double his income.

The advantage of silage consists not only in its cheapness but from the fact that it provides a most succulent feed with the least possible waste. There is also a marked difference in cows fed silage and cows not fed silage. My herd of six cows from Norember 1st, 1907 , to November 1 st, 1908 , returned $\$ 120.84$ or $\$ 70.14$ for each cow. These cows were fed no silage. From November 1st, 190s, to November 1st, 1909 , my herd of eight cow's returned $\$ 766.41$ or an average of $\$ 95.80$ per cow. These cows were fed silage eleven months. These were the cows that were in the previous herd but two cows were added. The herd consists of mixed breed and Holstein grades, bred to freshen fall and spring. Thus it will be noticed that the silage fed cows income was $\$ 153.96$ (counting six cows) more than the previous year and having the returns of two extra cows, besides having eight head of young cattle that are in nice thrifty growing condition being fed on silage. In the fall of $190 \mathrm{~S}$ I put five acres in my silo. lt lacked five feet of being full. In the fall of 1909 three and one-half acres filled it jammed full. Thus I conchude that the silo has paid for itself the first year. Could I expect any more? Yours truly,

D. A. BURKHOLDER,

Waseon, Ohio. 
Indiana Silo Co., Anderson, Ind.

Gentlemen:-In the summer of 1906 we erected an Indiana Silo. As it was one of the first silos in the locality there was more or less questioning among our doubting neighbors as to the advisability of such a course. Some even remarked that they would hate to put so much feed in there and risk losing it. But it didn't take unto itself wings and fly away, neither did it spoil. In fact the process of siloing rather improved the quality of the feed.

Many consider the silo to be an expensive building, a luxury only to be afforded by the wealthy, but those who have had experience will invariably say that more feed can be preserved in better shape, and at far less cost, than with any other form of farm building.

Corn is unquestionably the most profitable of our general farm clops, and it can be made vastly more profitable by the use of the silo. Forty per cent of the feeding value of the corn plant is in the stalk. What a waste to leave it standing in the field. Even when the fodder is cut and shocked there is considerable loss from weathering. The Colorado Experiment Station found by actual experiments that it lost from thirty-one to thirty-five per cent of its feeding value. We would estimate that in this locality the waste would be still greater, espe-

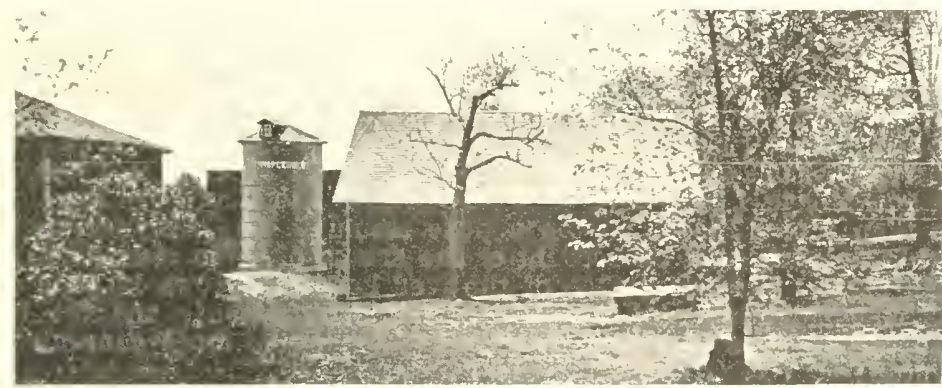

Mapledale Farm, H. J. Dickinson, Osage, Iowa.

cially when the shocks ale left in the field part or all of the winter. With the silo, however, the loss is almost unnoticeable, as it seldom exceeds five per cent of the total crop.

We consider it to be less work to fill the silo than to husk the corn and put up the dry fodder, and then the silage is much easier to feed. The silo ownel can but pity his unfortunate non-silo neighbor who must rise early and hie himself out to the field on a cold morning to chop a few frozen corn stalks from the snow bank. The cost of filling a silo is seventy-five cents to one dollar per ton, when the machinery and help is hired, but if one is fortunate enough to own a cutter and engine, the only expense is a few cents for gasoline.

Silage is uniform in quality throughout the entire winter. It is as succulent as June pasture and is relished by all classes of farm stock, especially dairy cattle. By the use of the Indiana Silo we now keep twelve cows with a higher average yield of dairy products, on the $\operatorname{sam} \theta$ acreage that formerly provided sustenance for but six. It has been said "Whoever makes two blades of grass grow where but one grew belore is a benefactor to mankind." Estimate, if you can, the countless mil. lions of wealth that would pour into the coffers of the country if every farmer in the land owned a silo.

H. J. DICKINSON, Osage, Ia. 


\section{SOUND AS EVER AFTER FOUR YEARS.}

Ixdian Silo Co., Axderson, IND.

Dear Sirs:-I purchased a silo from you four years ago, and will say I am well pleased with it. I consider it one of the best investments I have made in my life. There are a lot of silos in this neighborhood, but I know mine is the best and, also, the cheapest of them all and it freezes the least of any one of them, too, and the ensilage keeps fine right to the staves. No waste whataver in the four years I have had it and the staves and everything is just as sound and good as the day they were jut uy so they will last for many years and as to the money it has made ne every year I cannot say just on the dollars and cents, but the tirst year I had it I got more out of my herd of 10 cows over the year before, when I did not have a silo, than my silo cost me, so I guess it is a money-maker alright, so I heartily recommend it to all who want a silo and I have been recommenuing it to my neighbors, of which you will be aware by all the ordel's you will get from this locality. This winter I know fire orders are booked and more are sure to follow ba. fore suring.

Wishing you success in your business, l remain, yours truly,

$$
\begin{aligned}
& \text { GLI.BERT M. DAHLEN, } \\
& \text { Ogdensburg, Wis. }
\end{aligned}
$$

\section{DAIRY MAN CAN'T DO WITHOUT A SILO.}

Ivinax Silo Co., ANmerson, Ind.

Gentlemen:-I put up a silo in September in the autumn of 1906. I was late getting it but got it filled that year, my corn being uretty ripe, but made good silage. I have never had any trouble with silage spoiling, never more than : or 3 inches on top a little mouldy. The dairyman cannot afford to do without it on account of the saving of grain feed it enables him to make. The succulence of the feed keeps the coms in good condition, the palatability of it gives them a good appetite and the richness of it does away with the necessity of buring so much concentrated feed stuffs.

My experience in fceding silage proved that une can keep his cows in hettel How of milk on a ration of silage with from 4 to 6 pounds of grain per day than he can with dry feed or dry feed cut and mixed with from $\&$ to 10 pounds of grain. I a!n at lresent feeding 11 cows and an increase of 5 pounds per day per cow would mean an increase of at least 70 cents a day at the present prices of feed and in six months it would amount to $\$ 126.00$ or the entire cost of $\mathrm{my}$ silo, which is $12 \mathrm{ft}$. by $24 \mathrm{ft}$. My experience has been that putting corn in the silo was the cheapest means of gatherirg the corn crop, besides putting it away in such a condition as to get all of the food value out of it.

The cost of filling the silo will, of course, depend on how far you have to haul your corn and the available help. I own my own cutter, but hire an engine and other help but it hasn't cost me more than from $\$ 12$ to $\$ 15$ to fill mine, holding about 50 tons. It has been cheaper than shredding corn for me, but of course the cost of help and such like will vary with local conditions, and of course the cheaper you get your corn crop raised the cheaper feed you have, but after it is raised there is no question but what it is not only the best but the cheapest way of saving your feed in good condition. I am speaking altogether of coln silage as I have never tried any other kind myself. Yours truly, 
FACTS AND FIGURES FROM FOUR YEARS' EXPERIENCE.

Indiana Silo Co., ANDERson, IND.

Gentlemen:- I will give a few figures and say a few words in regard

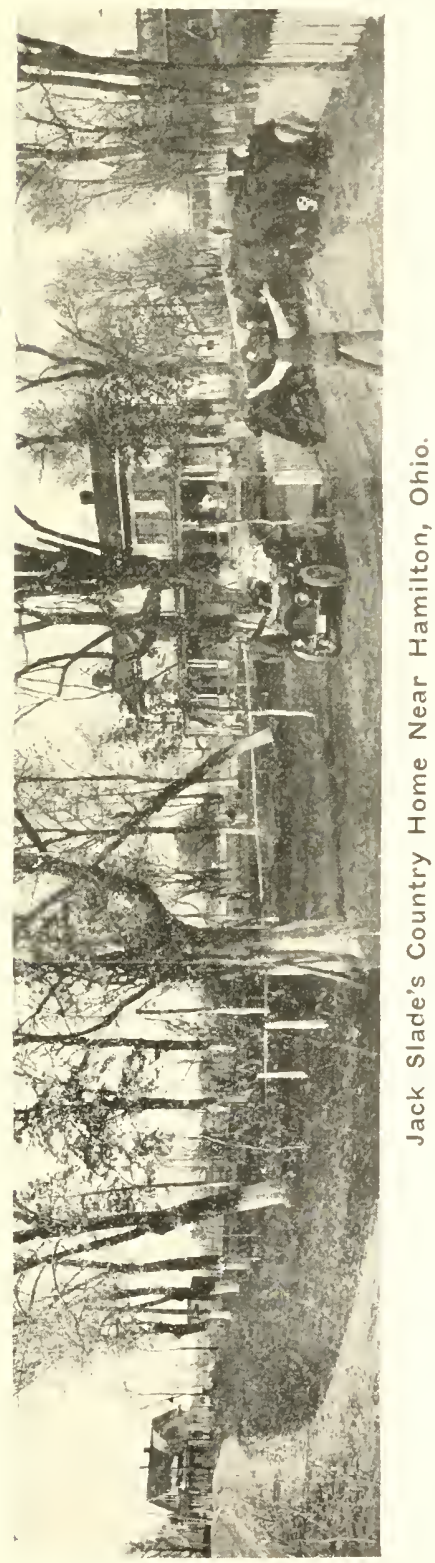

to feeding silage. I have been feeding and handling fat cattle for mole than thirty-rive years and I have made the business a success, financially. All farmer's will not make a success feed. ing cattle for profit. There is a large per cent. of farmers that would make more money if they sold their grain instead of feeding it to cattle. The profits on feeding stock for a period of, say, ten years, are not as great as the farmer and city man who never feed stock, might think.

A man to feed or haudle stock successfuliy, must have a liking for the business, and he must be, or soon learn to be, a good judge of stock, keep informed on the marliets and know when the stock is finished. The man that does not know the quality or the finish of his stock will sbip his cattle to market thinking he will get the top quotations given in his market paper, if he should have one. But when he sees the return of what they sold for he will be so dispirited that le will condemn the commission man and the man who bought them and swear that he will never ship to them again. But the man who is a judge of good cattle and knows when his stock is finished, will not miss vely much the amount he expected. Most any farmer can judge a hog as to it being fat, but there are very few who can judge a bullock. A man raising cattle should size up his shea room, decide about how much grain he wants to feed and in what malket he expects to sell. Then buy the weight to start on that when finished will suit his market best, and don't fail to sell as close to the feeding lot as you possibly can, for a!l small feoders who sell theil cattle at home lerive more returns from them than those that ship. There are times when the fteder is obliged to ship.

From my experience in handliu? and feeding cattle $I$ find that it requires shelter, plenty of bedding, and feed troughs and clean feed twice a day. Ion't allow strangers in your feed lot unless the regular feeder is with them. When the cattle have been fed and watered and have laid down, they should not be disturbed until thev 
get up on their own accord. The better the bed, the more they will lle down; the result being that they will take on greater weight. Never allow your cattle to become excited. If you do, you will lose more than you gain. Kill the dogs and keep the visitors out.

Some years ago two of our cattle men in this county built square silos of stone and concrete. I was very well acquainted with both of these gentlemen and I kept a close eye on the results of these silos, one for feed for fat cattle, and the other for daily purposes, and they did not prove successful.

They cut their corn too green, and their silo being square, it let the air in at the corners and it became sour, and to make it worse, they cpened it at the bottom and the results were the cattle did not do any good. So I came to the conclusion that a silo would not do. After a few more years rolled around the silo fever raised again. I got the fever and I visited several farms where there were round silos and they were all giving good satisfaction, so I came to the conclusion that I would buy one. I visited both Ohio and Indiana firms and I concluded that the Indiana Silo Company built the best silo on the market. l made a trip over to Anderson, Indiana, and went up to the office and made my wants known and what I was there for. I was shown through their factory and then I was asked to take a drive through the country and see some of their silos that were built for several years and I was surprised to see how well the wood was preserved, apparently as good as they were the day they were built, so I bought one of the Indiana Silo Company, September, $1906(16 \times 30)$, and had it built at the farm I live on. I was so well pleased with the gentlemen of the firm and with the silo that in 1907 I bought another $(16 \mathrm{x} 30)$, and put it on a farm three miles away. I never met a more honorable set of gentlemen to do business with in my life than the Indiana Silo firm. I expect to build a silo on each farm this summel. I think every farm ought to have a silo of some size on it. I am very sorry 1 did not have silos years ago. Just think what ten acres of corn will do by putting it into a silo, on an average of about 100 tons of good feed, and make more money thar any ten acres of hay that ever grew. What a shame it is to burn up the stalks when you can make so much use of them! Statks are now, as bran and cotton seed was a good many years ago. Run the bran through the seives and burn the cotton seed.

Is it any wonder that the boy leaves his country home, when he is sent out on a cold wintel day to the field with a team that is trying to break their necks to get away out of the cold to get a load of corn fodder? Shovel the snow off: get a pick to dig the ends loose out of frozen ground and finally get it onto the wagon and start for home with hardly enough feed to keep the cows from starving over night. Do the same thing over the next day; and that is not all: when he comes to hauling ont the manure and those stalks, if lie doesn't say cuss words he is a bird.

The man with the silo has put his corn fodder in when the days are long and warn and when it is a pleasure to feed the stock and see how they relish cheir feed. I have fed cattle many different kinds of feed and in different ways; corn on the ear chopped up; shelled corn; corn meal; corn and cob; ground; coln meal cooked into a slop, cattle tied up; malt; ba:ley sprouts; bran and beet putp; cotton seed meal; cotton seed hulls and silage; clover; alfalfa; oats and timothy hay; corn fodder run through cutter, shredied and whole.

If there is a man who can show me any way that he can produce more fat or growth out of corn or hay than he can through a silo, I wish he would get on the band wagon and let us hear from him. A man who las a sllo and a lot of cattle on hands doesn't have to fear the dry summers 
when the grass is burned up and is compelled to put his cattle on dry weather market. He can hold to them just as long as he wants to. I have come to the conclusion that we can realize more out of summer silo than to keep our land in blue grass. What would ten acres of blue grass produce to ten acres of corn fodder put in silos? You must not lose sight of the fact that it takes about 33 per cent. more head of stock today to supply the demands than it did twenty years ago, the difference being in weight then and now. Just as long as the demand is so strong for baby meat, as they call it, it will keep us farmers busy to raise enough to supply the demand.

I have read in different farm papers where men claimed that they have made a gain of three and one-half pounds per day on cattle, on dry feed in the winter season. I never have been able to make such gains on a lot of cattle in winter feeding. The same gentlemen claim they can make a hundred pounds of pork with eight bushels of corn and water, winter feeding. My experience has been, with good sleeping quarters and cement floors to feed on and a good grade of hogs to start with, it requires about eleven to twelve bushels of corn to produce one hundred pounds of pork. I never have been fortunate enough to own a cow that produced ten pounds of butter filty-two weeks in the year, or a chicken that laid 365 eggs in twelve months.

Now I want to say to the young man, don't give up the farm. It never looked better to me than it does now. Go to work. Take the bull by the horns and make up your mind that you are going to own a good farm some day. Build a silo. Have up-to-date implements and you will have less hours to work in a period of twelve months than any other business, and have the most independent and the best living on earth. In my opinion a man building a silo, it is far better to build two small ones (12x24), than to build one large one.

The following figures show the results I have obtained by silo feeding. Observe that all of my cattle are of light weight:

FIRST YEAR FEEDING, 1907.

Silo No. 1.

September 4th, 1906, bought i the Indiana Silo Company one silo, $16 \times 30$.

I had all of my land rented on shares and the tenant was to deliver my half of grain on the car. Instead of delivering it on the car he put my half, every other twenty rows, to the silo, and when he gathered his hall he weighed it as gathered, and that is the way I get the correct number of bushels of corn in the silo.

September 15, 1906, commenced filling silo. I furnished engine and cutter; cost...............

December 20, I bought in Evansville, Tenn., 41 steers, very common mountain cattle, $26,935 \mathrm{lbs} ., 2 \frac{1}{2} \mathrm{cts}$.

Freight on same

25.00

December 24, I bought in Cincinnati Stock Yards 20 common Southern cattle, 14,650 lbs., $31 / 2$ cts.....

I turned these cattle to a straw pile until January 1st, 1907, and then I commenced feeding silage lightly for about twenty days.

Put in silo $16^{\circ}$ acres of field corn, 800 bu, at $40 \mathrm{c} \ldots \ldots$.

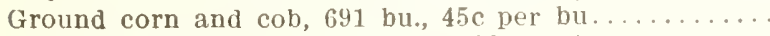

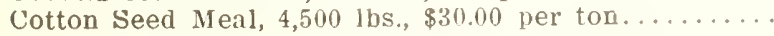

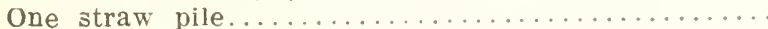

637.37

61.75

512.75

320.00

310.95

67.50

25.00

3.00 


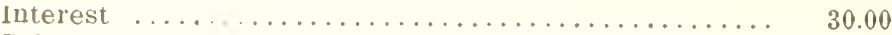

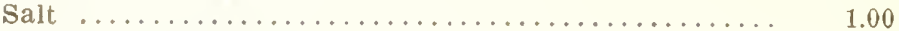

Labor for feeding cattle.................... 40.00

April 5, 1907, weight of 61 cattle at shipping station,

$58.130 \mathrm{lbs}$. Sold in Cincinnati Stock Yards. Freight,

yardage and commission................ 89.00

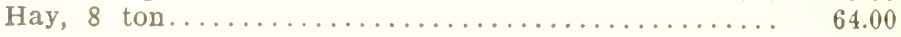

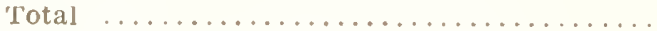

April, sold on a bad market, 56,030 lbs., in Cincinnati

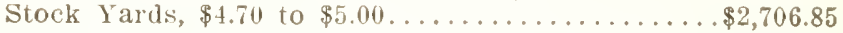

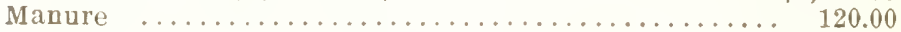

Net gain on hogs following cattle, 3,100 lbs., sold

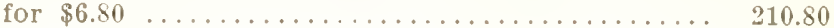

Total

$\$ 3,037.65$

Net protit

$\$ 850.33$

\section{SECOND YEAR FEEDING, 1908.}

Silo No. 1.

Silo was filled the same as first yoal by tenant, Sentember 20, 1447 , Filling silo, cost of engine and cutter..........\$ 25.00

Dec. 20th, bought in Chicago, full of water, 30 grade

Polled Angus steer's, 25,060 lbs., at $\$ 3.85$, and six, 4,040

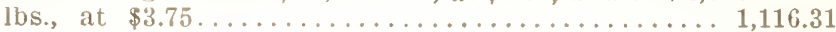

Freight

42.20

Turn the 36 cattle on stalks until Jan. 1, 1908; com-

menced leeding silage lightiy for 15 days.

Jan. 30 , bought at home 4 steers, $3,5301 \mathrm{bs}, 41 / 2 \mathrm{c} \ldots \ldots$.

Put in silo, 750 bu. of corn at $45 \mathrm{c} \ldots \ldots \ldots \ldots \ldots \ldots$

158.85

337.50

Ground corn and cob, 432 bur, at 55 c............. 22935

Four tons of cotton seed meal, $\$ 28.00$ per ton........ 112.00

Cotton hulis, $\$, \$ 95$ lbs., at $\$ 8.75$ per ton............ 38.90

Eicht tons of mixed hay at $\$ 9.00$ per ton . . . . . . . 72.00

Straw pile .......................... 30.00

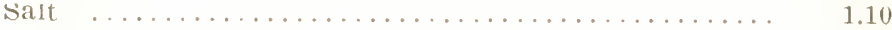

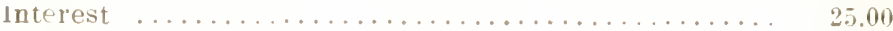

Labor for leeding ............................ 40.00

Malch 10 one steer died, 1,000 lbs

May 7, 1908, cattle weighed at station of shipment, t2, 230 lbs.

May 7 th, freight, commission and yardage on 39 cattle.

Gi. Ofi

$\$ 2,293.27$

1908.

May 8 , sold ('incinnati Stock Yards 40,630 lbs. for $\$ 6.66$

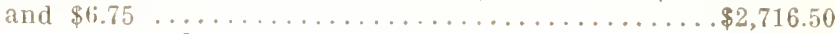

Manule, 440 loads ..................... 120.50

$\$ 2,836.50$

Jan. 1, bought 56 shoats to follow cattle, 9,425 lbs.,

Fed the hogs 446 bu. of corn, at $48 c$ per bu.........

400.56

$223.69 \$ 624,24$

April 6th, sold the 56 hogs, 15,050 lbs., at $\$ 6.10 \ldots \ldots .918 .05$

Net profit on cattle and hogs........... \$ 827.04

I would not have fed the cattle without the hogs and I would not have fed the hogs without the cattle. 
Silo filled as betore.

Cost of engine and cutter................\$ 25.00

Dec. 13 , bought in Chicago, 30 sieers, 23,490 lbs., $41 / 4 \mathrm{c}$ a

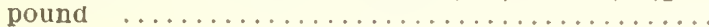

Freight

998.32

35.06

Jan. 2, bought in Cincinnati Stock Yards, 14 steers

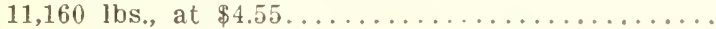
Jan. 5 commenced feeding silage. The cattle were Durham of tair grade.

Put in silo 20 acres of corn, very poor, 460 bu, at $60 \mathrm{c} .$. Ground corn and cob, 304 bu., $63 \frac{1}{2} \mathrm{c}$ to $70 \mathrm{c}$ a bu...... Cotton seed meal, 27,400 lbs, $\$ 28.00$ per ton.......... Hay, clover, 16,280 lbs., $\$ 10.00$ per toll............. Straw pile 507.78 salt

Interest

1909.

April 20, sold the above 44 cattle, 3-mile drive, 47,335

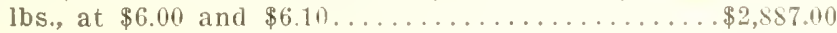

Manure

Jan. 20 , bought 95 head of pigs, $7,8601 \mathrm{bs}$.

Mill feed, 4,000 lbs., $\$ 28.00$ per ton.............. 56.00

Fed hogs 786 bu, of corn, at $60 \frac{1}{2}$ to $70 \mathrm{c}$, shelled.... 466.30

$\$ 867.85$

1908.

March 19, sold 15 hogs, 1,185 lbs., at $\$ 6.00$ per cwt....\$ 71.10 April 30 , sold 78 hogs, 15,000 lbs., at $\$ 7.30$ per cwt.... 1,160.70 Two hogs died. Net profit.

\section{FOURTH YEAR FEEDING, 1910.}

1910.

$$
\text { SIlo No. } 1 .
$$

Jan. 1, bought in Chicago, 61 head of graded Durham steer's; commenced feeding silage slowly for about 15 days.

Sixty-one cattle, weight 39,630 ibs., at $\$ 4.15 \ldots \ldots \ldots \$ 1,644.65$

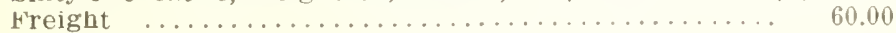

Put in silo 600 bu. of corn; ted 800 bu. of ground corn and cob with silage, 1,400 bil., at $60 \mathrm{c}$.

840.00 160.00

31.20

25.00

2.20

3.00

30.00

80.00

30.00

40.00 
1910.

April 23 , sold the 61 cattle, $3 \frac{1}{2}$-miles drive to where they were weighed; weight, 63,200 lbs., at $\$ 7.05$

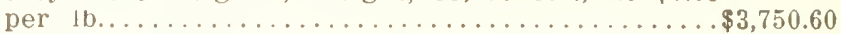

300 loads of manure.................... 100.00

$\$ 3,850.60$

1909.

Dec. 20), bought 85 pigs to follow cattle, 5,000 lbs . . . .\$ 374.00

Fed 550 bu. of corn, at 60 c per bul............ 330.00

$\$ 704.00$

March 31st, sold 22 hogs, 4,695 lbs., for $\$ 11.00 \ldots \ldots \ldots \$ 516.45$

April 26th, turned 34 on grass, $5,5.30$ lbs., worth $\$ 9.00 \ldots 377.70$

$\begin{array}{r}\$ 3, \$ 50.60 \\ 2,946.05 \\ \hline \begin{array}{r}904.55 \\ 192.15\end{array} \\ \hline \$ 1,096.70\end{array}$

FIRST YEAR FEEDING, 1908.

Silo No. 2 .

Silo No. 2, located two and one half miles from my home. Silo filled by tenants as Silo No. 1 .

Cost for engine and cutter................\$ 30.00

Dec. 20, 1907, bought in Chicago 31 Holstein steers,

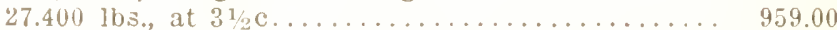

Freight ................................ 38.36

Turn above cattle on stalks until Jan. 10, and com.

menced teeding trom silo Jan. 10.......... 6.40

Put in silo 550 bu. of coln, at $50 \mathrm{c}$ per bu......... 275.00

Fed ground corn, 400 bu., at $50 \mathrm{c}$ per bu.......... 200.00

Four tons of cotton seed meal, $\$ 28.00$ per ton....... 112.00

$5, .00$ lbs. of cottom hulls, $\$ 8.00$ per ton.......... 22.00

Straw, labor, interest, salt and labor of feeding. . . . . $\quad 80.00 \quad \$ 1,722.76$

April 1, 1908,sold the :31 cattle, 33,120 1bs., at $61 / 4 \mathrm{c} \ldots \$ 2,070.00$

Manure ........................... 80.00

$\$ 2,150.00$

Hogs followed cattle turned on grass without weigh.

ing, profit, about....................... 120.00

June 15, 1908, filled silo with green clover hay, and I bought on Feb.

28,1909 , in Chicago, 28 head of springers and fed them the clover sllage.

I have never seen cattle do as well in my life as they did on that clover

sllage. If a man wants to or likes to handle springers, it is the sure money maker. My cows came fresh the last half of April and the firat half of May and 1 sold them for $\$ 60.00$ and $\$ 75.00$ a head. 
Filled by tenants.

Silo No. 2.

Cost of engine and cutter................\$ 30.00

1909.

Dec. 16, bought in Chicago, very common lot of cattle, 40 steers, $32,300 \mathrm{lbs}$. , at $\$ 3.30 \ldots \ldots \ldots \ldots \ldots \ldots 1,065.90$

Dec. 16, bought in Chicago, very common lot of cattle,

Freight

$y$ steers, $6,622 \mathrm{lbs} .$, at $3.60 \ldots \ldots \ldots \ldots \ldots \ldots \ldots$

Put these cattle on grass until Jan. 10, then opened silo and corn.

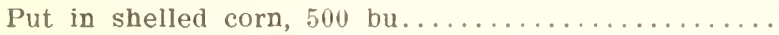

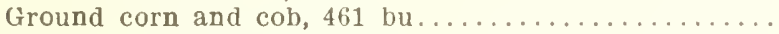

Five and a half tons of cotton seed meal, $\$ 32.00$ per ton.

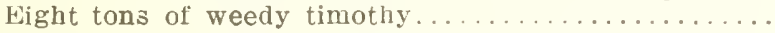

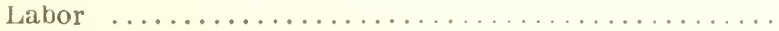

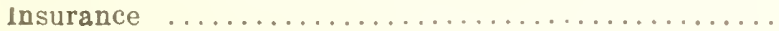

Salt

238.45

60.15

300.00

276.70

176.00

64.00

40.00

25.00

1.10

$\$ 2,277.30$

March 19. 1910, sold t9 cattle, 45,370 1bs., at $63 / 4$ c...\$3,062.47

Dec. 23, 1909, bought 40 Southern pigs, 2,570 lbs., at

$\$ 7.63$

196.10

January, 1910, 25 head of pigs died.

May 2 , sold the last 15 pigs, 2,470 lbs., at $91 / 4 \mathrm{c} \ldots \ldots .228 .47$

Net profit

$\$ 817.54$

Trusting this will be of some value to you and others, I remain yours very truly,

J. A. SLADE, Hamilton, $\mathrm{O}$.

\section{FIRST YEARS' EXPERIENCE.}

Indiana Silo Co., ANDERson, Ind.

Dear Sirs:-I use one of your silos and am always ready, and ever nave been, to give a reason for the faith that I have regarding the excellence of silos for economical and labor saving qualities. What I am going to tell you I have already told to scores of farmers who bave come to me to know personally what I had to say in their favor. This is what I had to say, and it was my first year's experience:

One of my fields of corn contained thirty acres. Thirteen acres of that field I cut and filled a silo $16 \times 30$. The remainder of the field, 17 acres, was cut and shocked the usual way. The 17 acres was fed first to a bunch of steers and seven cows. When the shocks were finished we used the silage and fed it to the same bunch of steers and the same cows with this result, that the 13 acres of silage lasted fully twice as long as the 17 acres of shocks, and when the steers were sold on the Chicago market they were equal in fiesh to any steers I ever fed and costing less labor and less high-priced feed. Cattle eat very little hay when fed good silage. That was my first year's experience and the next year I built a second silo and the outlook with me for a third silo is not impossible. Yours truly, J. F. HANNAY, Grinnell, Iowa. 


\section{COULDN'T RUN A FARM WITHOUT A SIL.O.}

Indena Silo Co., Anterson, Ind.

Gentlemen:-Yours of the 14 th inst. received soon after date. On acconnt of sickness in the family, hence this delay.

Now to give the exact dollar's and cents I lerive through the silo is almost impossible from the fact that I feed silage to most everything on the place for it is a pleasure to me to see stock eat it. This is my third season to feed out of silo. I would not want to run a farm any more without a silo for I keep and feed as much stock on my forty acles as most other farmel's do on eighty or one hundred acres in this lart of the country for others have told me the same. I am safe in saring I realize $\$ 3.0 .00$ or $\$ 400.00$ a year more than $I$ would if I had no silo. I have had men to say to me, "I don't see how you can keep so much stock so good as you do on forty acles," which I could not do if it were not tor my silo.

l have no thoto of my buildings nol stock to help you in that line. Yoursting tro

R. D. BARNHILL, Columbia City, Ind.

\section{AN ACRE OF CORN IN SILAGE WILL FEED ONE COW A YEAR.}

\section{INDIANA Silo Co., ANUERSON, IND.}

Gentlenten-I hate been using one of your silos for six years. It is still in good anditioli. I consider it the best investment I ever made. One acle of good corn will make ten tons of silage which will feed a cow one yeal, a bushel and one-half twice a day. My cows are well fed on a good digestible food and I have never had a cow that did not like silage. I raise this leed on one acre, otherwise it would take two acres of coln, from one to two acres of hay and two acles of pasture. I figme that I an saving at least four acres of my land. Putting it at ten dollar's an acre I am saving $\$ 40.00$ on one cow's feed. My silo holds 80 tons. I feed 8 cows one year you can see that I am saving $8 \mathrm{4} 40$, which is $\$ 320.00$. There is no question, can we afford a silo? We cannot afford to do without a silo.

1 would rather have the Indiana Silo than any I have ever seen. Yours vely truly,

O. E. BUTKNELI,

Madison, Ind

\section{CATTLE GROW IN WINTER AS WELL AS IN SUMMER.}

Inifixl Silo Co., ANuerson, Ind.

Gentlemen:-In 1908 I lurchased one of your $16 \times 30$ silos trom $\mathrm{Mr}$. Halgrove, Des Moines, Ia., and am very much pleased with the deal, both construction and results and otherwise.

I have a small 160 acre farm and before I got the silo I could keep on an average of flom 1; to 20 liead of cattle besides some logs and horses, enough to work the falm and those few cattle were not fed to a plofit by far. Now I am feeding 10 head of milch cows and 35 head of young stock and feed to a profit. They are now growing in winter as well as in summer. Before 1 got the silo and silage feed they would fall back in wintel what they gained in summer, but now I can keep them growing right along. Only one thing I am sorly for and that is I did not get one before. I cannot see why farmers are so slow about getting silos for I think it one of the best inventions on the farm. The first year I filled my silo with 12 acres of corn, last fail it did not take quite. that much. Yours truly,

GEO. H. BARNES, Huxley, Iowa. 


\section{A NEIGHBOR LOOKED ON-THEN DID LIKEWISE.}

Indiana Silo Co, Anderson, Ind.

Gentlemen:-The $12 \times 30$ silo I bought of you last Februaly, 1909, came alright. Every piece was firstclass and it fit perfectly.

I filled it on the 4 th of September. It took seven acres of good corn. I fed $1 S$ head of milch cows, 3 yearlings from the 20 th of September until now and my cows are looking fine, fifty per cent better than they looked last winter, when I fed all the hay they would eat and ten pounds of mill feed per head.

Last winter I sold $\$ 400.00$ worth of milk and it took the most of that to buy mill feed. This winter I have sold $\$ 600.00$ worth of milk and haven't got my check for March. I fed some mill feed this winter. One of my neighbors laughed at me for building my silo. He said one year would do me. He saw my cows when I began feeding silage and he knew how much milk I have sold this winter and he knows how my cows looked last winter and now he is going to buy an Indiana silo. That is what my neighbor says now. Yours very truly,

HARRY DOBBS,

Herrick, Ill.

\section{TEN HEAD ON TEN ACRES WITH SILO.}

Indiana Silo Co., Axperson, Inu.

Gentlemen:- The $10 \times 20$ silo I received from you two years ago has proved itself satisfactory in all respects.

I have ten acres of land. Since I got your silo I can keep five milk cows, calves and a couple of yearlings. Before I fed silage I could hardly keep thlee cows. My cows have increased each 75 per cent in milking since $I$ fed silage. The silo is as good as the day it was put up. It has not decayed any.

I think an Indiana Silo will keep as long as any other building if properly taken care of. Yours truly,

S. O. ANDERSON,

Stone City, Iowa.

\section{FIVE OF HIS NEIGHBORS SAW THE ADVANTAGE AND BOUGHT SILOS.}

Indixa Silo Co., Axnerson, InD.

Gentlemen:- I installed one of youl silos three years ago, having filled it three seasons and I regard it as indispensable to dairymen and cattle feeders, as it not only affords the cheapest succulent feed, but by its use one can save crops other than corn regaldless of wet weather. After feeding silage the first season my cattle came through the winter in such excellent condition that five of my neighbors who saw them bought your silos and are now using them. My silo after three years use is as good as new.

As to the profits from feeding silage you can say it maintains the flow of milk wonderfully and last year at May 1st we lum out of silage and notwithstanding that we fed more concentrates and that the cows had some grass the herd of thirteen cows, the total number, fell off eight gallons per day and I figure I lost $\$ 39.68$ in the one month from being out of silage. Am enclosing photo which kindly return and also send me book of articles. Respectfully, 


\section{ENSILAGE FOR SHEEP.}

INIJANA Silo Co., ANDERson, IND.

Gentlemen:-I have been feeding ensilage to sheep four years and find it a vely satisfactory food. The ewes are very greedy for it, eating the entirn plant, stock, blade, husk, corn and cob, when fed not to exceed two pounds per head per day. We have the lambs dropped early in February and March. The ewes give a good flow of milk and we have never

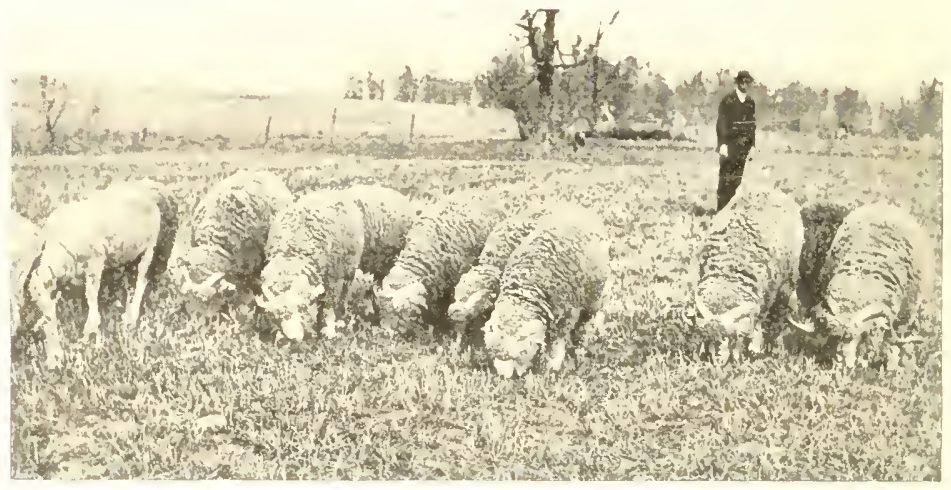

J. E. Orebaugh's Delaine Yearlings Wintered on Silage; Sheared 161/2 Lb8.

had any trouble with lamb cholera, as frequently occurs when turning ewes and lambs from dry feed to fresh spring pasture.

Our shee; are registered Delaines and the rams shown are great fellows for ensilage. Sincerely yours,

P. S.- "Sure Mike," ours is an INDIANA SILO.

J. E, OREBAUGH, Wiimington, Ohio.

\section{ONCE AGAIN AS MUCH MILK WITH SILO.}

Ixdiaxa Silo Co., Axderson, Ind.

Gentiemen:- I would be very glad to slow you the picture of my silo, but I can't, it is in the barry. I can say the silo is a dandy. I don't think there is anything better that will beat the silo.

I had a silo but I wish I had another one $14 \times 20$ so I could feed the whole year around. The silage is very gool for milking cows. I have had once again as much milk since I have had a silo than when I had nont. The silage is very good for cattle, sheep and pigs. The silo saves me a great deal of work. I had no trouble in putting this silo together. The lumber in it is No. 1, in fact, you have treated me well.

Wishing you good luck in your work, I remain, yours very truly, MARTIN BASTIAN,

Brillion, Wis.

\section{CATTLE QUIT GROUND FEED FOR SILAGE.}

IXDiAxA Silo Co., ANDERSon, Ind.

Gentlemen:- The Long Leaf Yellow Pine Silo I bought of your agent at the State Fail, Louisville, Fy., Septenber, - - was delivered promptly andi with the help of farm hands was erected with ease. Every piece was first class material and fitted perfectly and when completed was very neat and attractive. It being the first silo built 
in the county was quite attractive to many of my visitors and quite a number will be built in this county the coming season.

I began filling my silo in three days after it reached my farm with corn-fliling it half full and the remaining half I filled with Sorghum cane and a better feed could not be obtaiued from farm products than I fed from my silo.

I began feeding ensilage Nov. 15th to twenty (20) head of dairy cows and twenty (20) head of stock cattle. My cattle would quit eating ary kind of ground food for ensilage.

There is no loss in feeding from the silo.

Fol the dairyman or cattle raiser the silo is the key to success, handy and always ready to feed from.

Ensilage is the most essential of all prepared feed.

I have saved during the time at least one-half of the grain feed and have had better results from my cows during the winter than I ever had before. My cows improved in flesh and milk from the time I began feeding ensilage. I finished my silo feed April 15th and my cows failed from the last feed. Only Wish for more ensilage. I could not afford to do without a silo if I had to buy one each season. Will placo my order with you for another one this season.

Wishing you a continued success, I am as ever, your friend,

JAMES A. BURRES,

Valley Stock Farm, Leitchfield, Ky.

\section{A THIRD MORE MILK ON ENSILAGE THAN ON DRY FEED.}

Indiana Silo Co., Anderson, Ind.

Gentlemen:-I purchased a silo of the Indiana Silo Company for my dairy cows and flock of sheep and am well satisfied with the results for both.

In the first place ensilage is much more digestible than hard corn so that it does so much more good towards producing milk and keeps the stock in good condition and no prepared food is required.

Before I put up my silo I dug foul feet in the ground and started foundation and dug out middle and made solid cement bottom and sides and thereby got 28 feet space out of a 24 foot silo. It cost me $\$ 18.25$ to get it flled, besides swapping work with some of the neighbors and paying the cutter's and got 112 tous of good ensilage. It would have cost that much to hire the corn gathered and left fodder in the field and it is claimed that the fodder is worth as much as the corn. So I think I gained at least $\$ 15.00$ in that way. And then more milk is produced, the cows give one-third more milk on ensilage than on dry feed. I send on all average of 2,700 lbs of milk per month and counting one-third gain would be 900 lbs. or $\$ 12.82$. Sheep do well on it, they like the soft corn it contains and when the big snow was on 17 inches deep they were kept in the barn and had no other kind of feed for over two weeks except some clover hay and they seemed to thrive on it. I, also, give some to my hogs occasionally in cold weather they like it and serves the place of grass or clover.

Now comparing it with shredded fodder there are so many hard parts of the stalk in it that the cows do not eat and we have to throw out whereas in the ensilage all parts are soft and palatable that they eat it all up clean and thereby save all of it.

WeIl, I believe that is all I think of now but there are doubtless other benefits of the silo.

WILLIAM H. COOK, Mooresville, Ind. 


\section{SILOS AS MONEY MAKERS.}

INDAMA SHLO Co., ANDERSON, IND.

Gentlemen:- The silo I bought from your agent in 1908 is makiug big money for me. My herd averaged 5,025 lbs. more milk for the six winter months when I fed silage than they did the winter before without the silage and the same amount of cows. I fed an average of 30 lbs. less

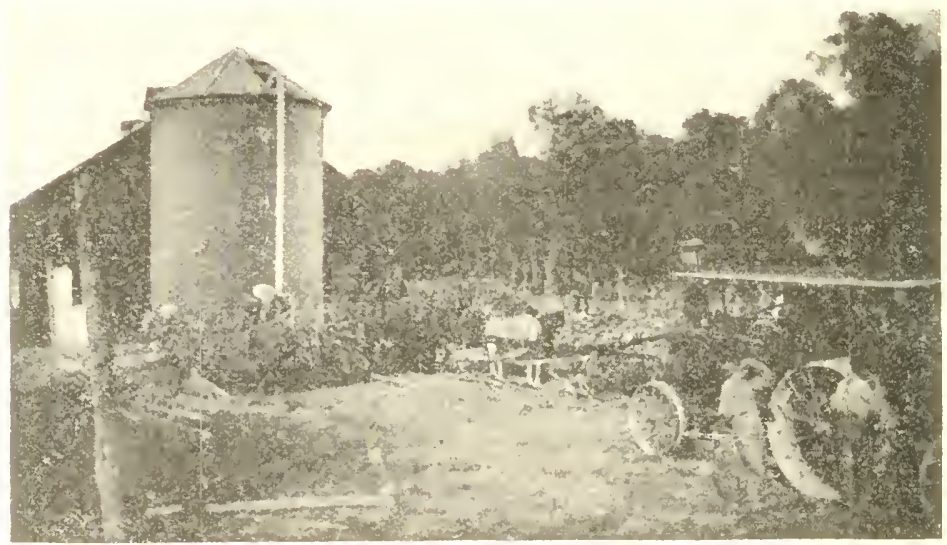

Filling Joseph Alenbrock's Silo, Effington, III.

grain a day, a saving of 4 kc a day, and ny cows are in better shape than they were a few years ago.

Will recommend any farmer and dairyman who is in need of a silo to the Indiana Silo company, and to buy their silo. You will get a first class silo. This is the photo of my silo. Yours truly,

TOSEPH ATLENBROCK.

Effingliam, Ill,

INDJANA SH, ('U, AVDFRSOX, IND.

Geutlemen:- In answer to your inquiry for profits made in using an Indiana Silo I can't tell with exactness, yet can give a pretty close guess. I think l have at least realized 27 per cent more gain over the non-silo way on the same amount of land worked up in ensilage, and my corn got dried up very hady before I could get it mut in the silo. As many know, last year the weather was such that the corm just dried up in so short a time that it took some of us unawares. I am so pleased with the results that I want to use more of the corn plant that way. It is so handy to get at to feed when it is stormy or snow is all over the ground. The cattle have not missed a feed and cows kept right on giving milk; did not shrink but very little the coldest weather we had and this has been an exceptionally cold winter. I did not feed any ensilage to hogs, but they followed the cattle and it seemed to do them good, as they grew very fast and were admired by all passersy. Ilere it is, all in a nut shell. Feed ensilage to the cow with bran and what other feed she needs, get plenty of milk; feed the skim milk to pigs. sell butter, return the manure to the land and raise more corn to raise into ensilage. I have never covered two-thirds as much ground as with manure that was made from the silo. Gave some bran and hay to cattle and plenty of straw bedding. and you 
be: I have had a job hauling manure. 1 don't get too much of that commodity on my farm, as the time is not very far away when the owners of a well fertilized farm will have one of the best assets that I know of.

Yours truly,

J. A, BROYLES,

Clay City, Ill.

Indiana Silo Co., Anderson, Ind,

Gentlemen:-As I am an Indiana Silo man, would say that it is a fine thing to have, and makes the very best of feed. Mlakes more milk and better looking cows and I wish to say this that we never had any trouble with our cows cleaning at calving time, and I did before, and the first year that I filled my silo I put in two loads of sweet corn on trial and it was so good that we put in a good deal more the next year. I think if everybody knew how good the feed was they would bave one instead of haying it on marshes and on shares.

I must close, hoping you will weigh this for what it is worth.

I would say that I have moved to Redgranite now and my son will work the farm, Yours truiy,

JAS. McBRAIR,

Redgranite, Wis.

PROFIT ON SMALL SILO OVER $\$ 400.00$.

Indiana Silo Co., Anderson, Ind.

Gentlemen:-I received your letter wishing me to state the results I had received from using the silo.

I will say this in regard to the silo. We have fed since November 1st, 1909, 22 head of cows and four horses on the same amount of hay and less corn than I fed to six cows and three horses one year ago. One year ago I sold my milk from October 29, 1908, to March 1, 1909, and received from the six cows $\$ 115.74$ and sold two calves bringing $\$ 13.00$, making a total of $\$ 128.74$, and bought of concentrated feed $\$ 30.00$, leaving me a balance of $\$ 98.74$. Did not keep any hogs. This last winter since Norember 1, 1909, to February 24, 1910, we sold cream, $\$ 438.35$; calves, $\$ 40.00$, and hogs, $\$ 169.06$, making a total of $\$ 647.41$. We bought concentrated feed, $\$ 129.84$, leaving a balance of $\$ 517.57$. The $\$ 129.84$ paid for feed includes the hog feed bought.

After using the silo and obtaining such good results I do not see why dairymen are so backward and afraid to invest their money in a silo. February 23, 19I0. I bought out Ridley's interest here and since that time have been feeding 10 cows and have ensilage enough to feed about three weeks yet. Yours trily,

EDSON L. CUMMINS, South Haven, Mich. 


\section{STATE OF INDIANA,}

County of Madison, ss.

I, Wm. M. Swain, President of the Indiana Silo Company, of Anderson, Indiana, being first duly sworn, upon my oath say: That the foregoing letters, written to the Indiana Silo Company by the persons signing same, to the best of my knowledge, are true and correct copies of the letters received by said Silo Company; that no alterations have been made in any of these letters except minor changes of punctuation and spelling.

$$
\text { WM. M. SWAIN. }
$$

Subscribed and sworn to before me this 15th day of October, 1910.

$$
\begin{gathered}
\text { BERTRAM G. TAMLIN, } \\
\text { Notary Public. }
\end{gathered}
$$

My commission expires March 19th, 1911. 
Copyright 1910, by Indiana Silo Co All rights reserved. 


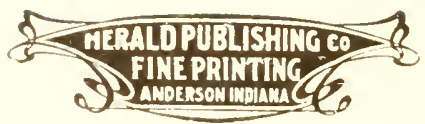


One copy del. to Cat. Div. 


\section{DEC 17 :3rn}

LIBRARY OF CONGRESS

Nits

isterin-

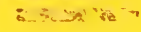

( 0027661725
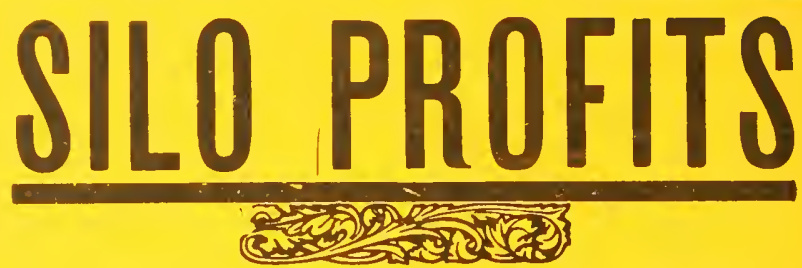

WRITTEN BY 200 OF THE BEST

FARMERS IN AMERICA 